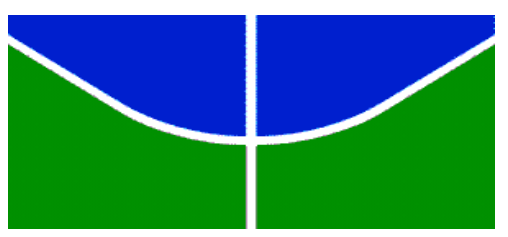

Universidade de Brasília Centro de Excelência em Turismo Mestrado Profissional em Turismo

\title{
EDUCAÇÃO PATRIMONIAL NA ESCOLA ESTADUAL DE ENSINO FUNDAMENTAL E MÉDIO FREI AMBRÓSIO EM SANTARÉM-PA E A FORMAÇÃO DO TURISTA CIDADÃO
}

Elias Mota Vasconcelos 


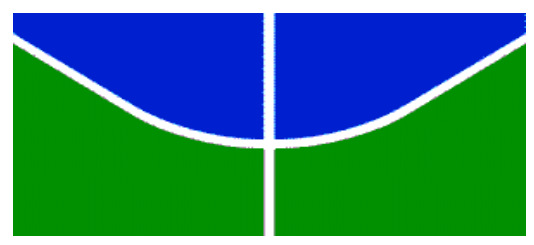

Universidade de Brasília

Centro de Excelência em Turismo

Mestrado Profissional em Turismo

\section{EDUCAÇÃO PATRIMONIAL NA ESCOLA ESTADUAL DE ENSINO FUNDAMENTAL E MÉDIO FREI AMBRÓSIO EM SANTARÉM-PA E A FORMAÇÃO DO TURISTA CIDADÃO}

Elias Mota Vasconcelos

Dissertação apresentada ao Programa de Pós-Graduação em Turismo, Mestrado Profissional em Turismo, da Universidade de Brasília - Área de Concentração: Cultura e Desenvolvimento Regional; Linha de Pesquisa: Cultura e Sustentabilidade no Turismo -, como requisito parcial para obtenção do título de Mestre em Turismo.

Orientadora: Profa. Dra . Eloísa Pereira Barroso 
Ficha catalográfica elaborada automaticamente, com os dados fornecidos pelo(a) autor(a)

Vasconcelos, Elias Mota

Educação Patrimonial na Escola Estadual de Ensino Fundamental e Médio Frei Ambrósio em Santarém-PA e a Formação do Turista Cidadão / Elias Mota Vasconcelos; orientador Eloísa Pereira Barroso. -- Brasília, 2015. $212 \mathrm{p}$.

Dissertação (Mestrado - Mestrado Profissional em Turismo) -- Universidade de Brasília, 2015.

1. Educação Patrimonial. 2. Patrimônio Histórico e Cultural. 3. Bens Culturais. 4. Turista Cidadão. 5. Turismo. I. Barroso, Eloísa Pereira, orient. II. Título. 


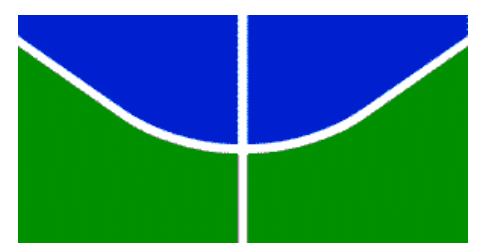

Universidade de Brasília

Centro de Excelência em Turismo

Mestrado Profissional em Turismo

Dissertação de autoria de Elias Mota Vasconcelos, intitulada Educação Patrimonial na Escola Estadual de Ensino Fundamental e Médio Frei Ambrósio em SantarémPará e a Formação do Turista Cidadão, submetida ao Centro de Excelência em Turismo da Universidade de Brasília - Área de Concentração: Cultura e Desenvolvimento Regional; Linha de Pesquisa: Cultura e Sustentabilidade no Turismo -, como parte dos requisitos necessários para obtenção do grau de Mestre em Turismo, defendida e aprovada pela banca examinadora abaixo assinada:

Profa $^{a}$. Dra ${ }^{\mathrm{a}}$. Eloísa Pereira Barroso (Presidente)

Universidade de Brasília - CET/ UnB

Pofa. Dr ${ }^{a}$. Karina e Silva Dias (Avaliador Externo)

Universidade de Brasília - IDA/ UnB

Profa. Dr ${ }^{\text {a }}$. lara Lucia Gomes Brasileiro (Avaliador Interno)

Universidade de Brasília - CET/ UnB

Prof $^{a}$. Dra . Neuza de Farias Araújo (Avaliador Suplente)

Universidade de Brasília - CET/ UnB

Brasília, julho de 2015. 
Dedico este trabalho a minha mãe, Adriana Mota, pelo incentivo ao estudo e amor incondicional carinhosamente dispensado a mim. 


\section{AGRADECIMENTOS}

Agradeço primeiramente a Deus, Pai Superior, fonte de amor, sustentáculo de minha fé, durante os momentos de aflição e cansaço.

A minha mãezinha, Adriana Mota, que sempre está comigo compartilhando meus projetos, objetivos, meu crescimento pessoal e profissional.

A minha orientadora, Prof ${ }^{a}$ Dra $^{a}$ Eloísa Barroso, por estar comigo nesta difícil, mas gratificante conquista.

Ao Instituto Federal do Pará, Campus Santarém, por ter me concedido afastamento de minhas atividades laborais para estudar em Brasília.

À Profa Dra Karina Dias, pela valiosa contribuição a esta pesquisa no momento de minha qualificação. Suas sugestões foram importantíssimas para compor o referencial teórico.

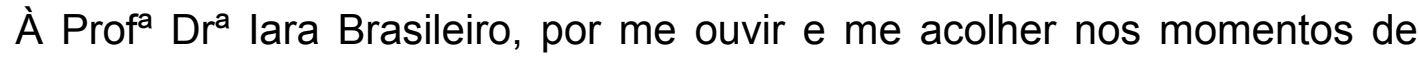
angústias. Seus ensinamentos e seu profissionalismo são inspiração para mim.

A todos os professores do Programa de Pós-Graduação em Turismo do Centro de Excelência em Turismo-CET/UnB e colaboradores.

A Denise Nunes (bibliotecária), por sua disponibilidade em me orientar na busca por publicações no início do Mestrado.

A todos os amigos da Turma do Mestrado 2013: Agatha Guerra, Alexander Malaver, Ana Paula Jacques, Bárbara Lins, Carolina Palhares, Daniela Leite, Edvard Santos, Elaine Borges, Elvio Cavaton, Erika Kilbert, Fabiana Oliveira, Fernanda Sant'anna, Gabriel Galvão, Hugo Almeida, Kelly Bedaque, Lívia Wiesinieski, Luis Eduardo Barros, Murilo Rocha, Nádia Nunes, Rogério Galeno, Simone Spindola, Tatiana Terra, Tamara Nicolau, Thiago Gabriel Daher. Formamos uma grande família, por todos os momentos que passamos juntos, foi maravilhoso!

À Escola Frei Ambrósio, na pessoa de seu diretor Profo Marcos Venício e da vice-diretora, Profa Pierlisia Moreira, que, desde o primeiro contato, me receberam com profissionalismo e apreço.

A todos os alunos que concederam as entrevistas, pois sem eles este estudo não teria sido concretizado. 
A todos os professores que colaboraram com as entrevistas, seus ensinamentos, experiências, determinação, foram vitais e serviram de estímulo para mim.

A Simara Bernardes (Técnica em Educação da Escola), por sua colaboração durante as entrevistas.

A todos os amigos que sempre estiveram comigo, torcendo para que eu conseguisse realizar esse sonho e, em especial, Ansleíria Rodrigues, você é um grande exemplo de superação e estímulo!

A todos os ex-alunos que torceram por mim, durante a realização deste objetivo.

Ao Ignácio Ubirajara Bentes de Sousa Neto, pela valiosa contribuição no que se refere às fotografias antigas de Santarém.

Ao Christian Soares, por ter cedido algumas de suas fotos para este estudo.

A Estefany Couto, pela contribuição com algumas fotografias.

Ao meu guru intelectual, mestre dos mestres, fonte de inspiração, Paulo Freire, que despertou em mim, ainda mais, o gosto pelo ofício de ser professor/educador.

Muito Obrigado!! 
"Ensinar não é transferir conhecimento, mas criar as possibilidades para a sua produção ou a sua construção".

(Paulo Freire) 


\section{RESUMO}

Esta dissertação teve como propósito analisar as representações que os alunos do Ensino Fundamental e os professores da Escola Estadual de Ensino Fundamental e Médio Frei Ambrósio construíram sobre o Patrimônio Histórico e Cultural da Cidade de Santarém/PA e suas compreensões sobre Educação Patrimonial, na perspectiva da formação do Turista Cidadão. Para alcançar as representações dos sujeitos supracitados, partindo de uma perspectiva de pesquisa descritiva, exploratória e qualitativa, recorreu-se à metodologia da história oral, através da aplicação de entrevistas gravadas em áudio e, posteriormente, transcritas para análise. Através desta pesquisa, conjecturou-se que a Educação Patrimonial é: um instrumento muito importante para a construção da cidadania e preservação dos bens patrimoniais localizados no Centro Histórico de Santarém, recorte espacial da pesquisa, considerado como lugar de memória e importante para a cultura e identidade local; um instrumento de capital importância na formação do Turista Cidadão, pois através de práticas pedagógicas, tais como as desenvolvidas na Escola Frei Ambrósio, é possível fazer com que os educandos exercitem um olhar de estranhamento e criticidade sobre o próprio Patrimônio de sua cidade, o que proporciona a criação de um contexto de identificação desses sujeitos com os Patrimônios e, por conseguinte, conhecimento de sua história e das identidades locais.

PALAVRAS-CHAVE: Educação Patrimonial. Escola Frei Ambrósio. Centro Histórico de Santarém. Patrimônio. Turista Cidadão. 


\begin{abstract}
This dissertation aimed to analyze the representations that students and teachers of elementary school studies of the Elementary and High State School Frei Ambrósio built on the Historical and Cultural Patrimony of the City of Santarém/PA and their understanding heritage about education in the perspective of Tourist Citizen formation. To achieve the above representations of the subject, from a perspective of descriptive, exploratory and qualitative it was appealed to the methodology of oral history, through the application of audio taped interviews and later transcribed for analysis. Through this research, it's conjectured that the Heritage Education is: a very important tool citizenship building and preservation of assets located in Santarém History Center, spatial area of research, considered as a place of memory and important to the culture and local identity; an important capital instrument in shaping the Tourist Citizen, for through pedagogical practices such as those developed at the Frei Ambrósio School, it's possible to get the students to exercise an estrangement look and criticality about the patrimony of their own city, which provides the creation of a context of identification of these subjects with the Heritages and therefore, knowledge of its history and local identities.
\end{abstract}

KEYWORDS: Heritage Education. School Frei Ambrósio. Santarém Historical Center. Patrimony. Tourist Citizen. 


\section{LISTA DE FIGURAS}

Figura 1 - Prospecto da Vila Tapajós no início do século XVII, por João André Schwebel. 1756

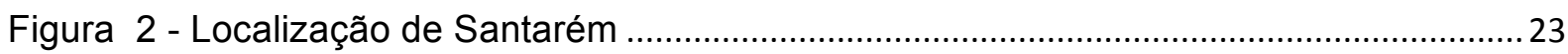

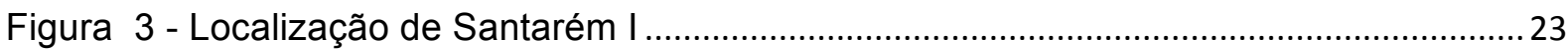

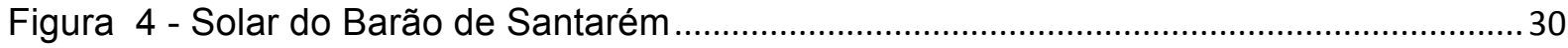

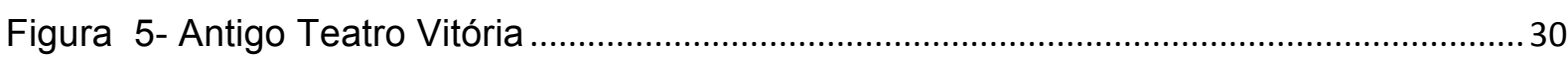

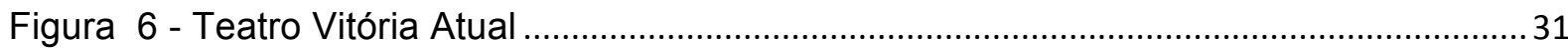

Figura 7- Centro Cultural João Fona - Museu de Santarém................................................... 31

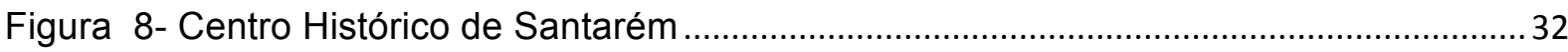

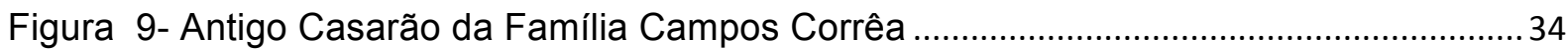

Figura 10 - Antigo Casarão da Família Campos Corrêa descaracterizado................................34

Figura 11- Sobrado conhecido popularmente como Castelinho Séc. XIX/Casa dos

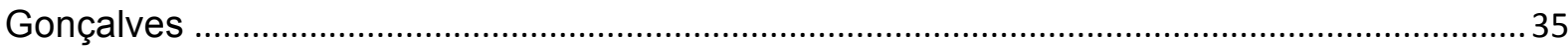

Figura 12 - Sobrado Castelinho/Casa dos Gonçalves na atualidade ....................................... 35

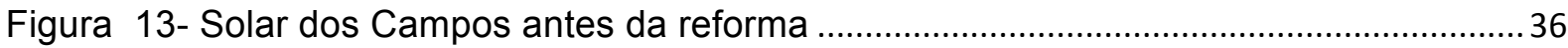

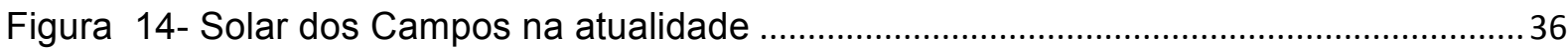

Figura 15- Patrimônio Edificado em bom estado de conservação ...............................................37

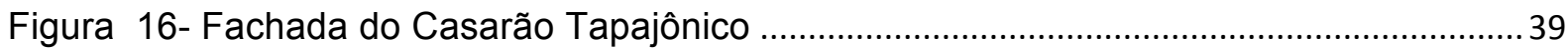

Figura 17- Parte Interna do Casarão Tapajônico totalmente demolida ..................................... 39

Figura 18 - Ato simbólico em frente à fachada da antiga Padaria Lucy ....................................40

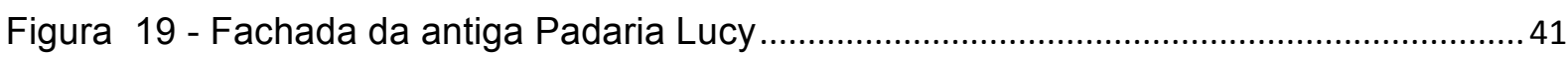

Figura 20- Detalhe da fachada da Padaria Lucy e azulejos portugueses do interior ............. 41

Figura 21 - Construção na parte interna da antiga padaria Lucy ao lado direito o que restou

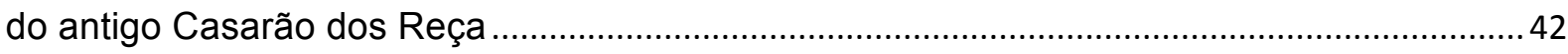

Figura 22- Antiga Casa de Saúde São Sebastião ………............................................................ 42

Figura 23 - Terreno onde ficava a Casa de Saúde São Sebastião .......................................... 43

Figura 24 - Igreja de Nossa Senhora da Saúde - Alter do Chão ............................................ 49

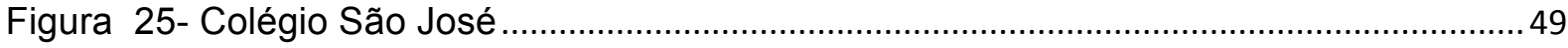

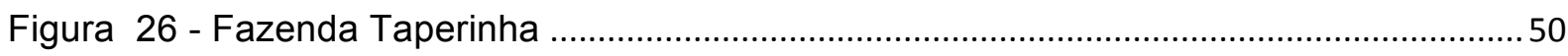

Figura 27- Igreja de Sant ana na Vila de Arapixuna ............................................................... 50 
Figura 28 - Igreja Matriz de Nossa Senhora da Conceição .......................................................58

Figura 29- Antiga Igreja Matriz de Nossa Senhora da Conceição.............................................. 58

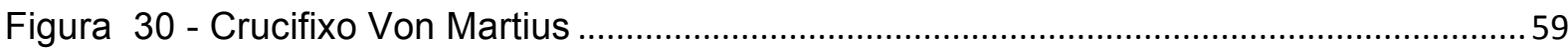

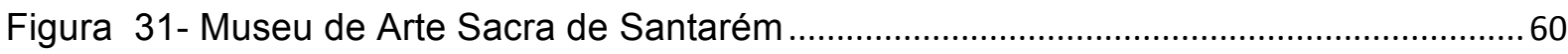

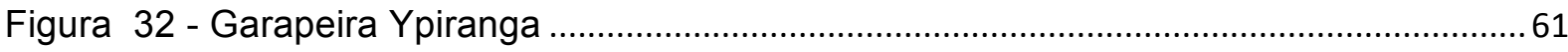

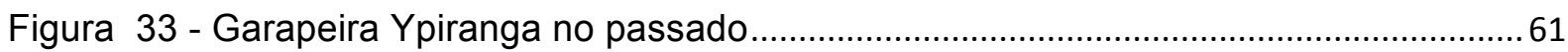

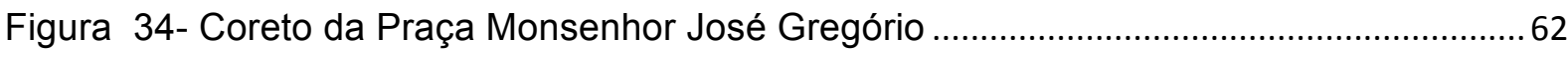

Figura 35 - Centro Cultural João Fona - Museu de Santarém .................................................63

Figura 36 - Interior do Centro Cultural João Fona - Museu de Santarém ................................64

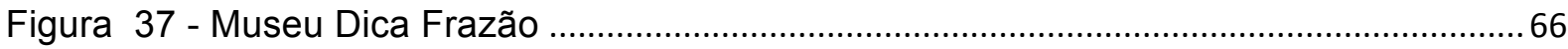

Figura 38 - Réplica da Vestimenta da Rainha Fabíola da Bélgica ............................................66

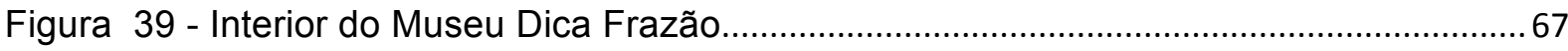

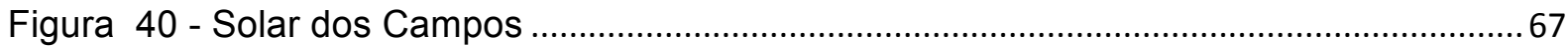

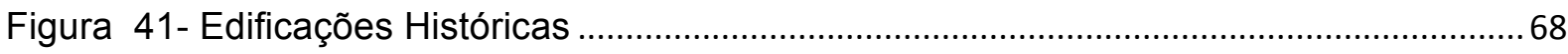

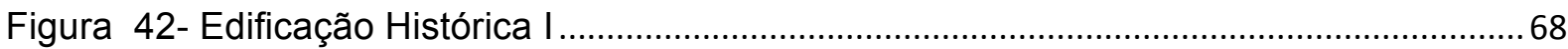

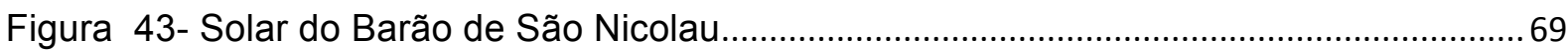

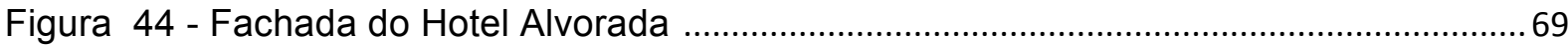

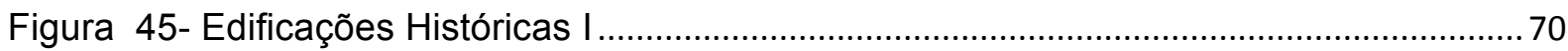

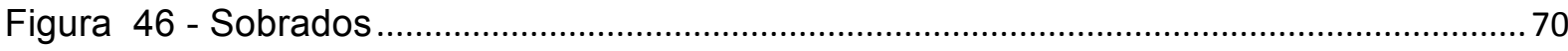

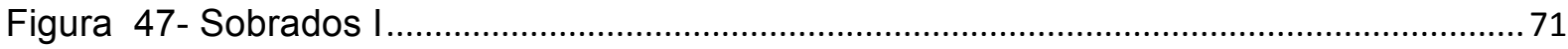

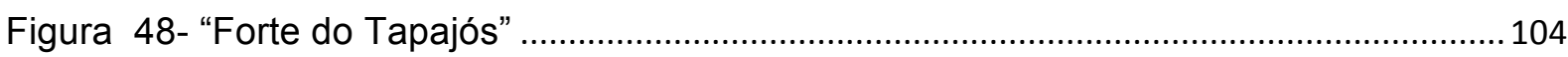

Figura 49- Frente da cidade com a "Fortaleza do Tapajós" ao fundo .................................... 104

Figura 50- Frente da cidade com a "Fortaleza do Tapajós" ao fundo I................................... 105

Figura 51- Praça do Mirante antes da revitalização .................................................................... 105

Figura 52 - Praça do Mirante na atualidade .......................................................................... 106

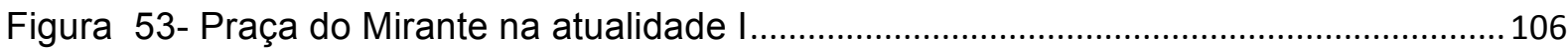

Figura 54- Frente da Escola Frei Ambrósio .......................................................................... 111

Figura 55 - Vista Aérea da Escola Frei Ambrósio .....................................................................111

Figura 56- Pavilhão Principal da Escola Frei Ambrósio ......................................................... 112

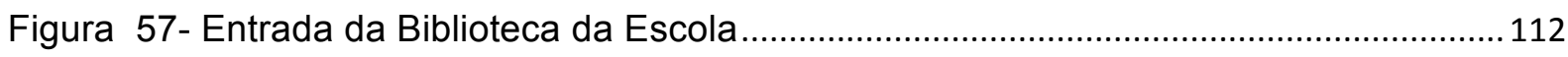

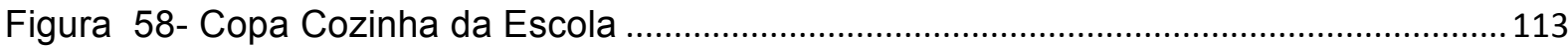




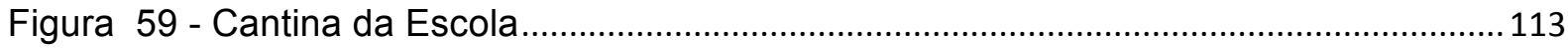

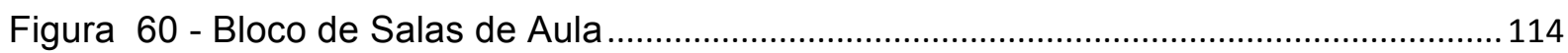

Figura 61 - Bloco de Salas de Aula em Reforma ..................................................................114

Figura 62 - Quadra de Esporte da Escola ........................................................................ 115

Figura 63 - Construção do Auditório da Escola ........................................................................115

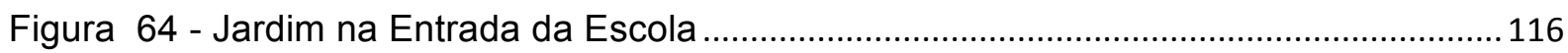

Figura 65 - Portão de Entrada da Escola ...........................................................................116

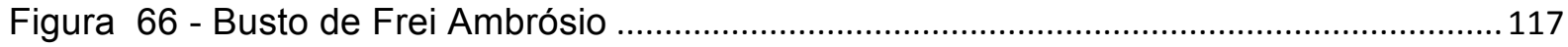

Figura 67- Alunos do Projeto Mais Educação Participando do Festival do Sairé 2014 -

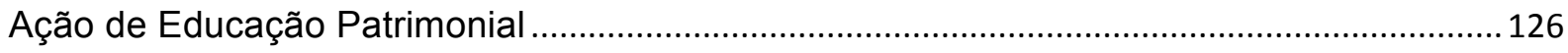

Figura 68 - Detalhe da pintura na parede da Escola que tem por objetivo informar sobre a

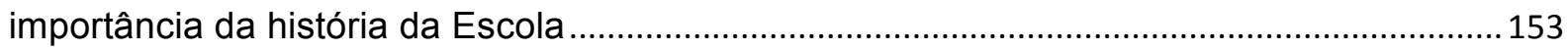

Figura 69- Detalhe da pintura na parede da Escola que tem por objetivo informar sobre a

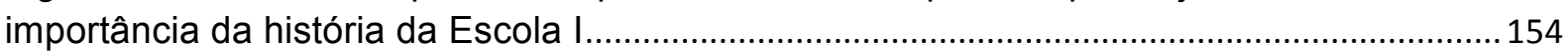

Figura 70 - Alunos do Projeto Mais Educação em visita a Feira da Cultura Popular ............155

Figura 71 - Alunos do Projeto Mais Educação em visita ao Centro Cultural João Fona Ação de Educação Patrimonial desenvolvida pela Escola ........................................................155

Figura 72 - Alunos do Projeto Mais Educação em Visita ao Centro Cultural João Fona Ação de Educação Patrimonial/Conversando com o Diretor do Centro, Laurimar Leal.........157

Figura 73 - Alunos do Projeto Sol Cidadão Legal depois da apresentação da Peça O Auto

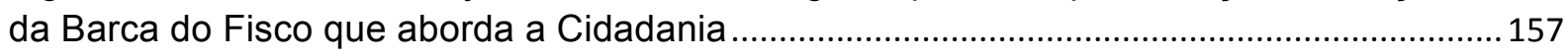

Figura 74 - Alunos do Projeto Sol Cidadão Legal em atividade contra o Racismo/Afirmação

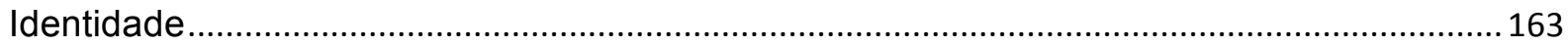

Figura 75 - Alunos do Projeto Sol Cidadão Legal realizando atividade que envolve Cidadania 


\section{LISTA DE TABELAS}

Tabela 1 - Distritos e Bairros de Santarém 


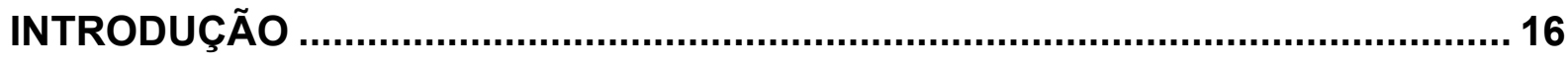

10 CENTRO HISTÓRICO DE SANTARÉM: O ESPAÇO EDIFICADO ...................21

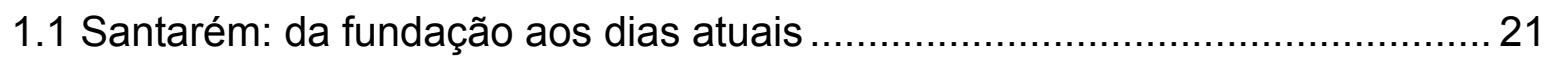

1.2 O Centro Histórico de Santarém: o que se perdeu e o que ainda permanece

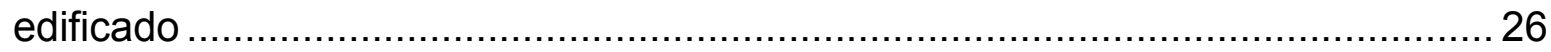

1.3 Um tour pelo Centro Histórico de Santarém ................................................ 56

1.3.1 Igreja Matriz de Nossa Senhora da Conceição ............................................ 56

1.3.2 Centro Cultural João Fona - Museu de Santarém ...................................... 62

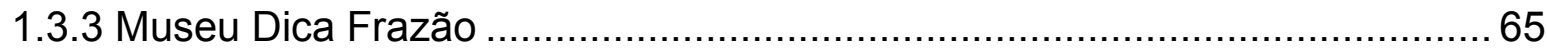

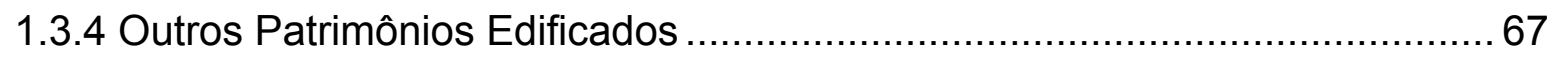

2 EDUCAÇÃO PATRIMONIAL E A FORMAÇÃO DO TURISTA CIDADÃO: UMA

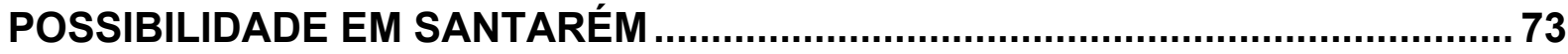

2.1 O Turismo e o Turista Cidadão: relações com a Educação Patrimonial .......... 86

3 EDUCAÇÃO PATRIMONIAL NA ESCOLA ESTADUAL DE ENSINO

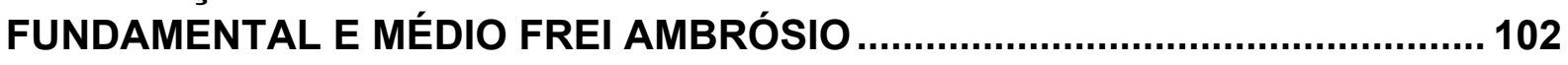

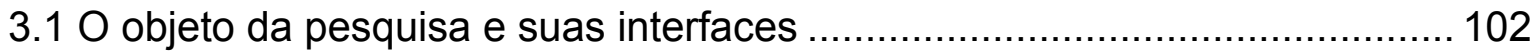

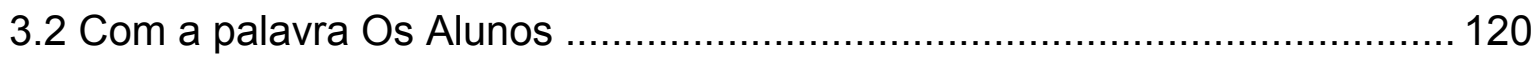

3.3 Com a palavra Os Professores ………................................................... 149

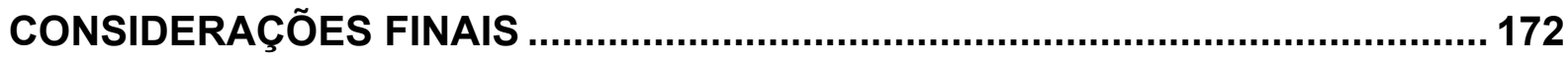

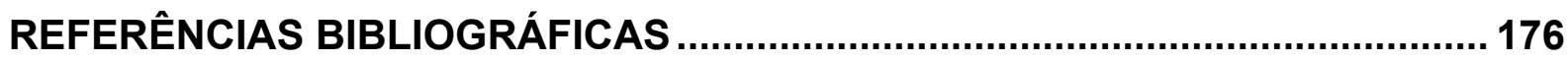

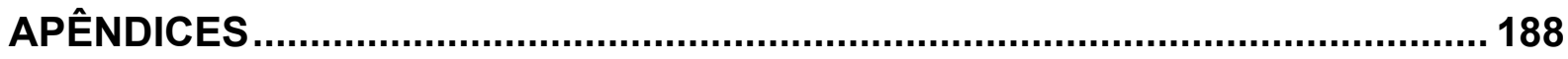

ANEXOS 


\section{INTRODUÇÃO}

Nos últimos anos, tem se verificado um avanço significativo na projeção do Brasil enquanto país que quer ser referência do Turismo para o mundo. Grandes eventos internacionais como a Copa do Mundo da FIFA, de 2014, e os Jogos Olímpicos no Rio de Janeiro, em 2016, servem de vitrine do país no cenário internacional.

O Plano Nacional de Turismo (PNT), 2013-2016, tem como uma de suas metas transformar o Brasil no terceiro maior Produto Interno Bruto Turístico do Mundo em 2022, ficando atrás apenas da China e Estados Unidos.

De 2003 a 2009, o setor cresceu 32,4\%, enquanto que a economia brasileira apresentou expansão de 24,6\%. Estima-se que para o ano de 2022 o Turismo seja responsável por 3,63 milhões de empregos no Brasil (PLANO NACIONAL DE TURISMO, 2013-2016).

Ainda de acordo com o PNT (p. 16), "o setor turístico participa dessa nova fase de crescimento e se consolida como importante atividade econômica para a geração de emprego, desenvolvimento social, investimentos, infraestrutura e sustentabilidade".

No bojo de todas essas transformações que o Turismo vem passando ao longo dos anos, está Santarém, que foi escolhida como um dos 65 destinos indutores do Turismo no Brasil (PNT 2007-2011), justamente por apresentar características muito peculiares com forte poder de atração para turistas como sua beleza cênica nos aspectos naturais e culturais. São quilômetros de praias de água doce e cristalinas, areia branca, povo hospitaleiro, igarapés, florestas, cachoeiras, morros, entre outros. Por outro lado, a riqueza cultural da cidade ainda é pouco explorada, salvo a Festa do Sairé.

$E$ foi justamente pensando na cultura local que o estudo em tela enveredou pelo campo do Patrimônio Histórico, mais especificamente dos Patrimônios Edificados, onde há carência de pesquisas e publicações.

Dessa forma, uma das possibilidades para reverter esse cenário nada favorável à preservação e conservação dos Bens Patrimoniais da cidade é a Educação Patrimonial que já é estudada, debatida e difundida em alguns estados brasileiros, porém em fase embrionária, ainda, no norte do País. 
$\mathrm{Na}$ maioria das vezes, os alunos estão praticando ações de Educação Patrimonial, estão envolvidos em projetos que abordam a temática e não tem essa consciência.

Assim, esta pesquisa parte da hipótese que a Educação Patrimonial é uma das formas possíveis de fortalecimento dos vínculos sociais entre a cidade e seus habitantes. Pois, se compreendida como prática social, pode contribuir sobremaneira para a formação do turista cidadão.

A escolha da Escola Frei Ambrósio se justifica pelo fato de ser a mais antiga em atividade na cidade, pelos anos dedicados ao ensino, pelo conhecimento dos projetos desenvolvidos pela escola na construção do sujeito histórico, por sua localização privilegiada e toda a história que a envolve, desde o início onde a mesma funcionou até os dias atuais.

O ensino fundamental foi escolhido por ser uma fase em que o educando ainda está em processo de construção de sua consciência crítica, o que segundo Soares apud Oliveira e Wenceslau (2007, p. 33), "não tendo a carga de valores totalmente formada, possuem maior potencial para adquirir e transmitir noções de valorização e preservação dos patrimônios para os demais membros da comunidade".

Dessa forma, esta pesquisa teve como objetivo investigar qual a percepção de Educação Patrimonial têm os alunos do Ensino Fundamental e professores da Escola Estadual de Ensino Fundamental e Médio Frei Ambrósio, e sua relação para a formação do Turista Cidadão no Centro Histórico de Santarém/PA.

Para se chegar ao objetivo deste estudo foi utilizada a pesquisa qualitativa que, segundo Oliveira (2007, p. 37), "é um processo de reflexão e análise da realidade através da utilização de métodos e técnicas para a compreensão detalhada do objeto de estudo em seu contexto histórico e/ou segundo sua estruturação". Segundo Lira (2014, pp. 23-24), é uma perspectiva descritiva, visto que "sua preocupação é descrever um determinado fenômeno ou população tentando uma interpretação", e Exploratória "quando o fenômeno ainda não foi abundantemente estudado por outros autores e os dados são poucos".

A pesquisa documental foi realizada junto a EEEFM Frei Ambrósio, a fim de se obter dados primários sobre sua história, construção, banco de dados dos alunos, professores e demais funcionários, o Projeto Político Pedagógico para saber se existe alguma ação de Educação Patrimonial desenvolvida pela escola ou se existe 
alguma ação referente à preservação e conservação do patrimônio edificado e ações de cidadania.

Outros documentos foram pesquisados na Prefeitura Municipal de Santarém, através da Secretaria Municipal de Turismo, e documentos junto a Superintendência do Instituto do Patrimônio, Histórico e Artístico Nacional (IPHAN), sede Pará, em Belém, com intuito de se observar o que tem sido feito em benefício do patrimônio edificado em Santarém.

A pesquisa bibliográfica é essencial fonte de investigação, haja vista proporcionar ao pesquisador importante fonte de informação e conhecimento acerca dos assuntos que vão compor o corpo do trabalho. Nesse sentido, buscou-se livros, artigos, dissertações de mestrado, sites, etc.

Utilizou-se o método de pesquisa história oral conforme a acepção de Alberti (2005, p. 29): "a história oral não é um fim em si mesma, e sim um meio de conhecimento". Dessa forma, foram realizadas entrevistas com alunos do ensino fundamental e professores da EEEFM Frei Ambrósio para se saber qual a percepção de Educação Patrimonial eles têm, como entendem o Patrimônio Edificado no Centro Histórico de Santarém e qual o entendimento que têm sobre o Turismo e Turista Cidadão.

Para Meihy e Ribeiro (2011), a história oral diverge de entrevistas simples, isoladas, únicas e não gravadas em mídias, para esses autores não se deve chamar de história oral entrevistas comuns, haja vista em muitos casos elas se orientam por procedimentos e práticas diferentes, respeitáveis e legítimas. "O que caracteriza a entrevista em história oral é a sistematização dos processos organizados pela lógica proposta no projeto inicial" (MEIHY e RIBEIRO, 2011, p. 13).

A utilização da História Oral para esta pesquisa se justifica, porque foi necessário saber dos alunos do ensino fundamental e professores da EEEFM Frei Ambrósio o que eles sabem sobre a Educação Patrimonial, sobre os Patrimônios Edificados localizados no Centro Histórico de Santarém, Turismo e Turista Cidadão. Cada depoente tem uma opinião individual que poderá ser divergente ou não do outro. Saber qual a percepção desses atores sobre os temas acima citados é o cerne desta pesquisa. Para Delgado (2010, p. 18), "os depoimentos recolhidos através do procedimento de constituição de fontes orais traduzem visões particulares de processos coletivos". 
A pesquisa referente ao Patrimônio Histórico da qual faz parte o Centro Histórico de Santarém ainda é pouco explorada no município, os relatos são escassos, portanto, pesquisas atuais que utilizam o método da História Oral são bem vindas, pois podem agregar valor as pesquisas já existentes.

Para Delgado (2010, p. 15), "a história oral é um procedimento metodológico que busca, pela construção de fontes e documentos, registrar, através de narrativas induzidas e estimuladas, testemunhos, versões e interpretações sobre a história em suas múltiplas dimensões".

Nesse sentido, trazer os testemunhos dos alunos do ensino fundamental e professores da EEEFM Frei Ambrósio sobre o Centro Histórico de Santarém e a perspectiva que tem da Educação Patrimonial, Turismo e Turista Cidadão é um registro significativo como fonte de pesquisa, pois com dados científicos poderão ser pensadas alternativas para serem aplicadas na preservação e conservação do Patrimônio Edificado em Santarém.

A História Oral conforme Delgado (2010, p.19), possibilita inúmeras possibilidades metodológicas e cognitivas, dentre as quais, destacam- se: "revelar novos campos e temas para pesquisa, recuperar memórias locais, comunitárias, regionais, étnicas, de gênero, nacionais, entre outras, sob diferentes óticas e versões, recuperar informações sobre acontecimentos e processos".

A utilização da História Oral para esta pesquisa poderá revelar um "novo olhar" para os mais de cem anos de construção da EEEFM Frei Ambrósio e sua relação com o Centro Histórico de Santarém.

Dessa forma, estruturou-se esta dissertação em três capítulos, no intuito a facilitar a compreensão do tema da pesquisa, além da introdução, das considerações finais e referências bibliográficas.

O Primeiro Capítulo procurou contextualizar a cidade de Santarém, desde sua fundação até os dias atuais, destacando seu Centro Histórico e os Patrimônios Edificados que lá se encontram e outros com localização afastada. Foram elencadas as categorias Cultura, Patrimônio, Memória e Identidade para compor um referencial teórico consistente.

Neste trabalho, o conceito de cultura é entendido enquanto uma teia de significados tecida e retessida pelo ser humano, conforme acepção de Geertz (1989); na perspectiva de Bauman (2013), enquanto expressão das experiências humanas inscritas em suas mais diversas produções - arquitetônicas, artísticas, 
científicas, laborais, dentre outras -, sejam elas materiais ou imateriais. Sobre a noção de Patrimônio Histórico e Cultural, recorreu-se a pensadores que entendem os Bens Culturais enquanto aqueles que possuem capital e inegável valor para a comunidade que os elegem enquanto representativos de sua cultura, história e identidades. Entres os autores que compartilham com tal concepção, destacamos os seguintes: Françoise Choay, Margarita Barretto, José Reginaldo Gonçalves, Maria Cecília Londres Fonseca, Lúcia Luppi Oliveira, Dominique Poulot, dentre outros. Em relação à memória, trabalhamos com os conceitos de Jeudy (1999), Nora (1993) e Le Goff (2003). Sobre identidade recorremos às noções de Bauman (2005), Hall (2005) e Martins (2003), os quais entendem que não possuímos uma identidade, mas identidades que estão em constante processo de construção e ressignificação, portanto históricas e inacabadas.

No segundo capítulo é abordado a Educação Patrimonial e a formação do Turista Cidadão, enquanto uma possibilidade em Santarém do Pará. Para tanto, recorremos a autores que enfatizam a Educação enquanto práticas de ensino aprendizagem pautadas na dialogicidade, criticidade e crescimento humano, tal como abordadas por Paulo Freire e Edgar Morin, e as relacionamos com o papel da Educação Patrimonial na construção do Turista Cidadão, uma vez que a Educação Patrimonial tem como um de seus objetivos despertar no aluno um olhar crítico e de estranhamento sobre os Patrimônios de sua cidade, proporcionando a eles entendimento de sua história e cultura, através de processos de identificação com os Bens Culturais.

O terceiro capítulo apresenta a pesquisa de campo com os alunos e professores da Escola Frei Ambrósio e suas percepções acerca das categorias Patrimônio, Cultura, Cidadania, Turismo e Educação Patrimonial.

Por fim, conjecturamos, através dos resultados desta pesquisa, que a Educação Patrimonial, através de práticas pedagógicas, tais como as desenvolvidas na Escola Estadual de Ensino Fundamental e Médio Frei Ambrósio, contribuem para a formação de uma consciência crítica cidadã sobre a necessidade de se preservar os Bens Patrimoniais de nossas cidades, por entendê-los enquanto parte de nossa cultura, de nossa história, de nossa identidade. 


\section{CENTRO HISTÓRICO DE SANTARÉM: O ESPAÇO EDIFICADO}

\subsection{Santarém: da fundação aos dias atuais}

Estudiosos da história de Santarém ${ }^{1}$, entre eles Fonseca (2006), sustentam que o local onde está erguida a cidade era habitado por índios Tupaius ou Tapajós, quando do primeiro contato com os "brancos colonizadores". Esses índios pertenciam a uma das tribos da nação Tupuiuçu. Eram exímios mestres em olaria. Muitas das peças arqueológicas que, hoje, encontram-se espalhadas por museus no Brasil são provenientes daquela região.

Santarém do Pará - ou simplesmente "Pérola do Tapajós", como é chamada pelos santarenos - foi "fundada, em 22 de junho de $1661^{2}$, pelo jesuíta Padre João Felipe Bettendorff' (FONSECA, 2006, p. 52). O nome Santarém está intimamente relacionado à homônima cidade portuguesa, cuja lenda relata que havia uma cidade chamada Nabância, onde viviam dois nobres por nome Ermígio e sua esposa Eugênia que eram pais de Irene ou Iria, formosa, casta e cheia de virtudes. Irene ou Iria, desde criança, fora prometida à vida religiosa, por isso residia em um convento, onde era educada por duas tias freiras. Um fidalgo por nome Teobaldo viu a jovem por entre as grades do claustro e se apaixonou perdidamente. Ele, então, resolveu pedir aos pais da jovem para casar-se com ela, porém foi repelido, pois a moça era prometida à Igreja. Tomado de ira, ele drogou a jovem e a raptou, porém, passado o efeito da droga, Irene ou Iria o rejeitou. Ele, enfurecido, a degolou e jogou o seu corpo no rio Nabão. A corrente do Nabão levou o corpo até à margem da cidade de Escalabis, onde os anjos thes construíram um lindo túmulo de alabastro. A notícia se espalhou por toda a Lusitânia, e de toda parte chegavam pessoas para venerar o túmulo da virgem mártir. Com o passar dos anos, Escalabis teve seu nome alterado para

\footnotetext{
${ }^{1}$ Para uma maior compreensão da história de Santarém, consultar a obra Tupaiulândia, de Paulo Rodrigues dos Santos (1999), pois, conforme apresentação de Lúcio Flávio Pinto, na referida publicação: "Com suas deficiências e limitações, Tupaiulândia é a mais bem organizada história de Santarém, até hoje escrita".

${ }^{2}$ Conforme Lei Municipal no 9.270, de 02 de junho de 1981, ficou estabelecido o dia 22/06/1661 como

${ }^{2}$ Conforme Lei Municipal no 9.270, de 02 de junho de 1981, ficou estabelecido o dia 22/06/1661 como a data oficial da fundação de Santarém (FONSECA, 1996 p. 21).
} 
Sant'Irene, daí passando a ser chamada Santarém (SANTOS, 1999, pp. 129130).

Figura 1 - Prospecto da Vila Tapajós no início do século XVII, por João André Schwebel. 1756

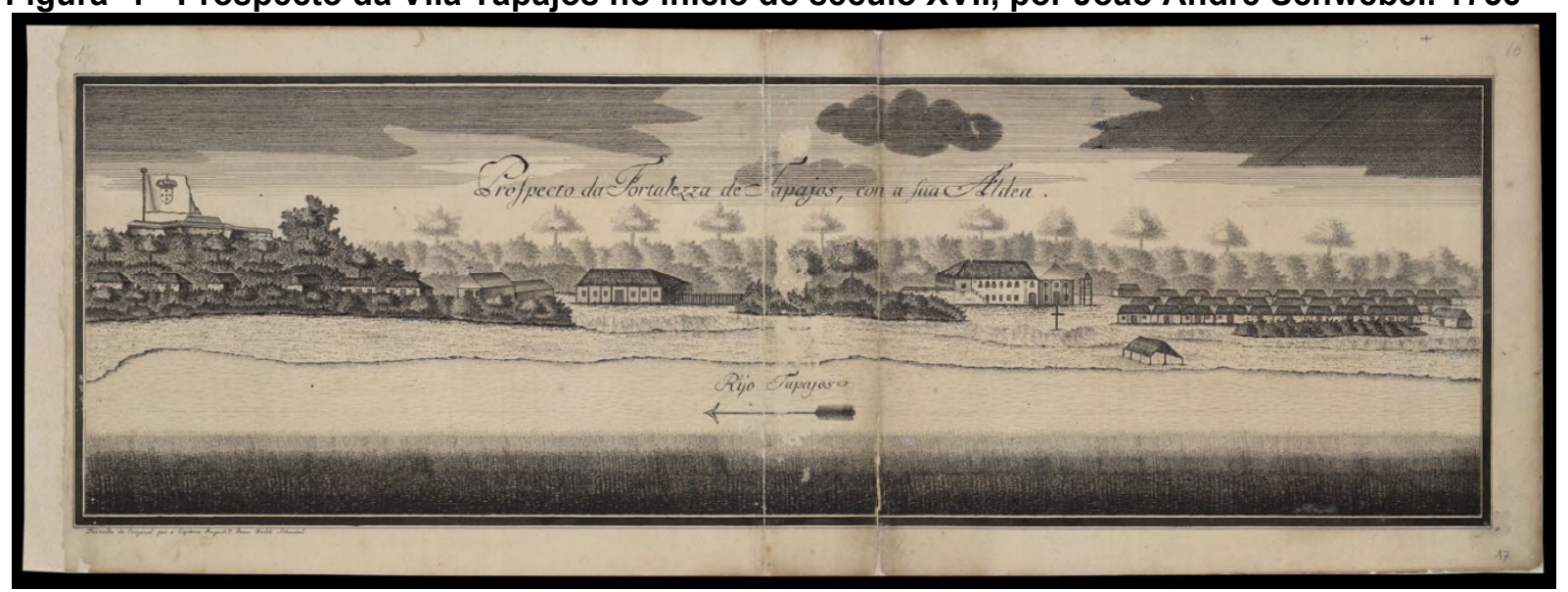

Fonte: Couto, 2013

Em 14 de março de 1758, a então Aldeia dos Tapajós recebe o nome de Santarém, passando de Aldeia para Vila. Trata-se de uma homenagem, do então Governador do Grão-Pará Francisco Xavier de Mendonça Furtado (irmão do Marques de Pombal), ao rei de Portugal. Em 24 de outubro de 1848, o presidente da província, Jerônimo Francisco Coelho, instituiu a Lei Provincial $n^{\circ} 145$, que eleva Santarém da categoria de vila à cidade.

Passados mais de 350 anos de sua fundação, muita coisa mudou no município que conta hoje, segundo o Instituto Brasileiro de Geografia e Estatística (IBGE), com uma população estimada de 290.521 habitantes, em 2014 (IBGE, 2014), área territorial de $22.886,624 \mathrm{Km}^{2}$ e densidade demográfica de 12,87 habitantes por $\mathrm{km}^{2}$.

A cidade localiza-se ao norte do país, Região Oeste do Pará e Mesorregião do Baixo Amazonas. Está distante da capital, Belém, aproximadamente 807 km, em linha reta (SEMTUR, 2013). 
Figura 2 - Localização de Santarém

MAPA DA REGIÃO NORTE BRASIL - MUNICIPIO DE SANTARÉM

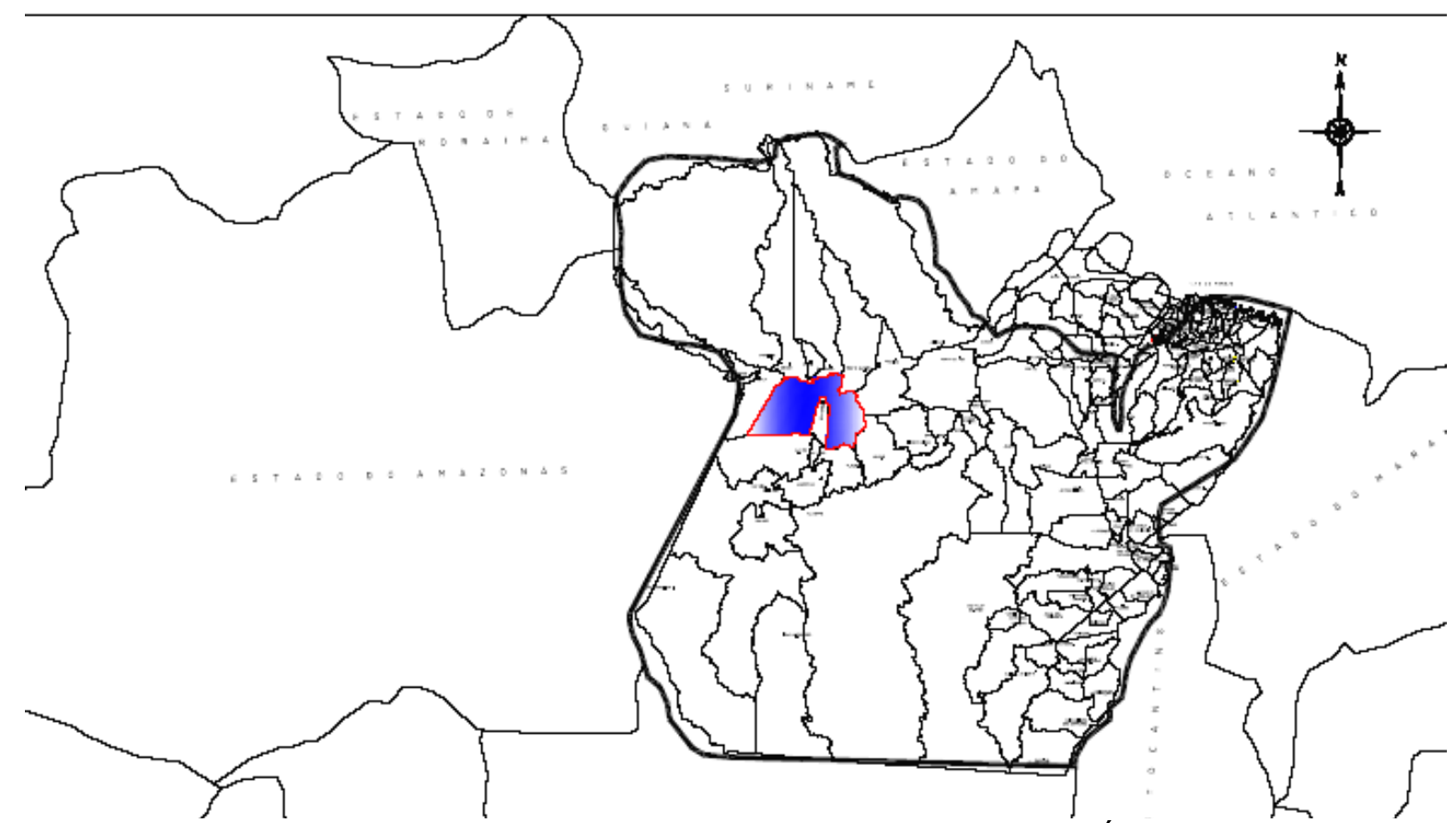

Fonte: SECRETARIA MUNICIPAL DE MEIO AMBIENTE DE SANTARÉM. CENTRO DE INFORMAÇÕES AMBIENTAIS (CIAM). Informações Municipais de Santarém. Santarém: SEMMA/CIAM, 2013.

Figura 3 - Localização de Santarém I

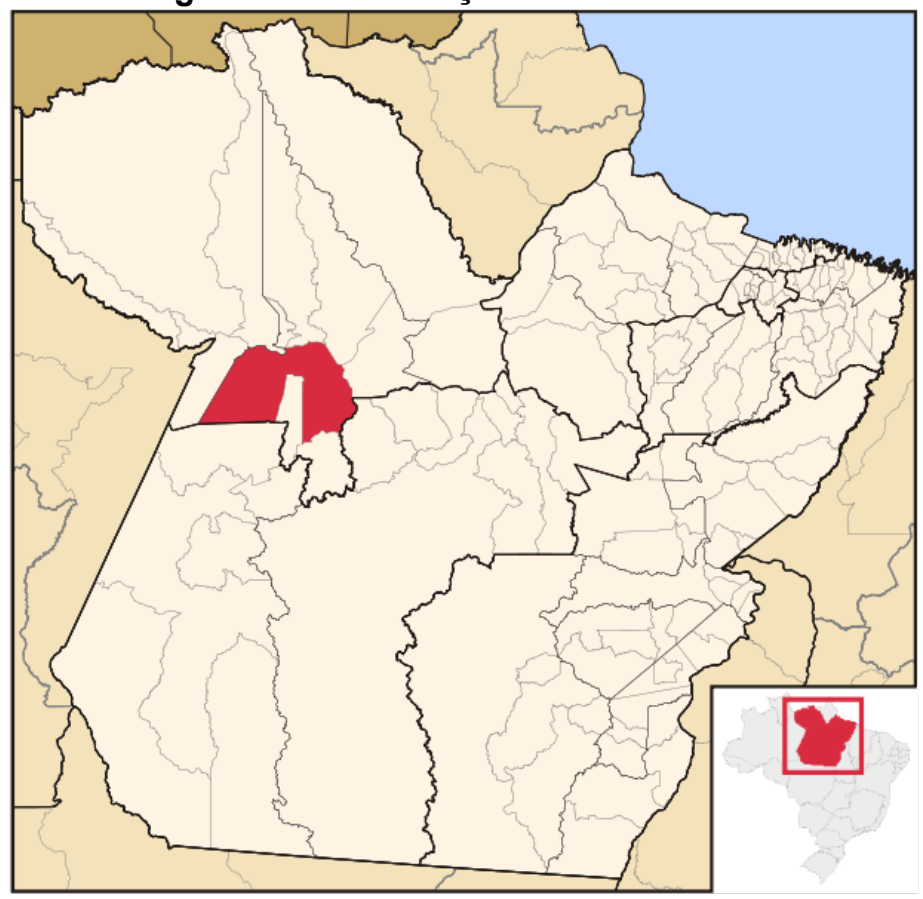

Fonte: http://www.skyscrapercity.com 
Santarém faz fronteira ao norte com as cidades de Óbidos, Alenquer e Monte Alegre; ao sul, com as cidades de Rurópolis e Placas; a leste, com Prainha e Uruará; a oeste, com Juruti e Aveiro e; ao centro, com a cidade de Belterra.

Conforme o Plano Diretor $\mathrm{n}^{\circ} 18.051$ de 2006, a cidade é dividida em distritos, sendo que, na zona urbana, são cinco compreendendo 48 bairros (Tabela 1).

Tabela 1 - Distritos e Bairros de Santarém

\begin{tabular}{|c|c|}
\hline Distritos & Bairros \\
\hline Aldeia & $\begin{array}{l}\text { Caranazal, Liberdade, Mapiri, Salé, } \\
\text { Laguinho, Fátima, Aparecida, Centro, } \\
\text { Santa Clara, Aldeia, Jardim Santarém, } \\
\text { Aeroporto Velho e Esperança. }\end{array}$ \\
\hline Prainha & $\begin{array}{lll}\text { Prainha, } & \text { Santíssimo, } & \text { Santana, } \\
\text { Livramento, São José } & \text { Operário, } \\
\text { Uruará, Área Verde, } & \text { Urumari, } \\
\text { Interventoria e Diamantino. } & \end{array}$ \\
\hline Maicá & $\begin{array}{l}\text { Jutaí, Pérola do Maicá, Maicá, } \\
\text { Jaderlândia, Vigia, Urumanduba e } \\
\text { Mararu. }\end{array}$ \\
\hline Nova República & $\begin{array}{l}\text { Floresta, Santo André, São Francisco, } \\
\text { Nova República, Matinha, Cambuquira, } \\
\text { Vitória Régia e Ipanema. }\end{array}$ \\
\hline Santarenzinho & $\begin{array}{l}\text { Maracanã, Maracanã 1, Elcione } \\
\text { Barbalho, Nova Vitória, Santarenzinho, } \\
\text { Amparo, Novo Horizonte, São } \\
\text { Cristovão, Conquista e Alvorada. }\end{array}$ \\
\hline
\end{tabular}

Fonte: SECRETARIA MUNICIPAL DE MEIO AMBIENTE DE SANTARÉM. CENTRO DE INFORMAÇÕES AMBIENTAIS (CIAM). Informações Municipais de Santarém. Santarém: SEMMA/CIAM, 2013. (Adaptação do autor)

A tabela foi criada para elucidar a área que compreende o Centro Histórico de Santarém, para efeito desta pesquisa. A área denominada Centro Histórico está contida nos bairros Centro e Prainha, da cidade de Santarém. A maior parte dos bens patrimoniais edificados está localizada no Bairro Centro, porém no limite do centro estão os bairros da Aldeia e Prainha, onde existem alguns patrimônios edificados que serão mostrados posteriormente, bem como um mapa da área do Centro Histórico de Santarém.

Santarém Constitui-se na terceira cidade mais populosa (PEREIRA, 2004, p. 77) e a segunda (SEMMA/CIAM, 2013, p. 10) mais importante do Estado do Pará, ficando atrás, apenas, da capital Belém e de Ananindeua. O seu desenvolvimento 
fica evidente pelo número de escolas municipais, estaduais e federal (Instituto Federal de Educação, Ciência e Tecnologia do Pará - IFPA), cursos profissionalizantes ofertados pelo Senai, Senac, Sesc e Sebrae, hospitais, universidades públicas e privadas, estradas, portos, comunicações, comércio, empresas hoteleiras, restaurantes, dentre outros. O acesso a Santarém se faz por vias aéreas, terrestres e fluviais (SEMTUR, 2013).

É considerada pelo Ministério do Turismo (MTur) como a principal cidade do Polo Tapajós ${ }^{3}$ e, também, a mais desenvolvida. Santarém apresenta vocação natural para o ecoturismo, turismo de base comunitária, turismo histórico-cultural, turismo gastronômico, turismo religioso e o turismo de aventura. Também apresenta grande potencial para desenvolver outros segmentos do setor, como o turismo de eventos e negócios. Por estas características, a cidade é considerada oficialmente pelo MTur como turística, desde 1998.

A cidade foi escolhida, em 2008, pelo MTur como um dos 65 municípios indutores do desenvolvimento turístico regional e, em 2010, foi destaque em uma publicação do MTur, em parceria com o Instituto Casa Brasil de Cultura, como destino referência em ecoturismo.

Todos os anos, a cidade recebe muitos turistas oriundos das mais diversas partes do Brasil e do mundo. Muitos desses estrangeiros chegam em navios de cruzeiros para conhecer Santarém e todos os seus encantos. São cruzeiros dos Estados Unidos, Europa e Ásia que têm rota garantida por Santarém, geralmente, entre os meses de outubro e maio. Porém, a escala de 2014/2015 ocorreu entre novembro e maio, conforme consta em anexo da pesquisa (SEMTUR, 2013).

Assim é Santarém:

\begin{abstract}
Situada no coração da Amazônia, apresenta vocação natural para o turismo ecológico, cultural e o turismo de aventura é evidente em função das suas belezas naturais: praias, cachoeiras, sítios arqueológicos, unidades de conservação, prédios históricos, edificações seculares, cerâmica tapajônica, o artesanato, a fauna, Floresta Nacional do Tapajós, lagos, igarapés, o espetáculo encontro dos rios Amazonas e Tapajós em frente à cidade (IPHAN/PA, 2010, p. 1).
\end{abstract}

\footnotetext{
${ }^{3}$ O Estado do Pará é dividido em 6 Polos Turísticos pelo MTur e o Polo Tapajós ao qual Santarém faz parte abrange as cidades de Alenquer, Monte Alegre, Óbidos e Oriximiná.
} 
Apesar de todo o inegável potencial turístico que a cidade possui, ela ainda precisa avançar muito em relação a esse setor, pois, há anos, ouve-se falar em potencial e pouco se percebe em ações concretas para o incremento e desenvolvimento desta atividade.

Sabe-se que para o turismo acontecer de forma salutar, faz-se necessário o envolvimento do poder público, dos empresários do setor e da comunidade. Esse tripé tem que estar em sintonia, caso contrário, o turismo corre o risco de estar fadado ao fracasso.

Considerando o patrimônio edificado de Santarém e sua importância para a história e memória da cidade, muito ainda tem que ser feito, tanto pelo poder público e o empresariado que detêm a posse de muitos bens patrimoniais, quanto pela comunidade, pois percebe-se que há certo desinteresse em se preservar e conservar esses bens que fazem parte da história viva da cidade. E como nos lembra Aloísio Magalhães apud Cerqueira (2008, p. 13), "A comunidade é a melhor guardiã do patrimônio. [...] Só se protege o que se ama, só se ama o que se conhece". É a comunidade que elege e reconhece o que é o seu patrimônio, para tanto, informação e conhecimento sobre categorias como cultura e patrimônio, torna-se um imperativo imprescindível nesse processo. Do mesmo pensamento comunga Ulhôa (2013, p. 98), ao afirmar que "essa escolha pode ser feita a partir daquilo que as pessoas consideram ser mais importante, mais representativo da sua identidade, da sua história, da sua cultura".

1.2 O Centro Histórico de Santarém: o que se perdeu e o que ainda permanece edificado

Os Centros Históricos das Cidades ${ }^{4}$ constituem-se em espaços de memória e significações múltiplas. Eles representam o retrato vivo de uma época no que concerne às suas transformações econômicas, políticas e sociais. Segundo o MTur (2010, p. 67), "é um sítio urbano localizado em área central da área sede do município, que se configura um centro tradicional em termos geográficos,

\footnotetext{
${ }^{4}$ Para Pesavento (2012, p. 397), "a cidade é o lugar que produz a diferença, estimula a diversidade, expõe o contraste, o pertencimento, a exclusão, a identidade e a alteridade".
} 
históricos ou funcionais". Ao lermos esta citação, podemos perceber que o Centro Histórico de Santarém está de acordo com tal perspectiva.

Pierre Nora (1993, p. 9) afirma que a memória "é a vida, sempre carregada por grupos vivos e, nesse sentido, ela está em permanente evolução, aberta à dialética da lembrança e do esquecimento". Nesse sentido, cabe aos grupos sociais elegerem o que é mais importante para suas vidas, seu passado, presente e futuro. Mário Chagas (2009, p. 136), em seu artigo Memória política e política de memória, corrobora para o debate ao afirmar que "o caráter seletivo da memória implica o reconhecimento de sua vulnerabilidade à ação política de eleger, reeleger, subtrair, adicionar, excluir e incluir fragmentos no campo do memorável".

Para Duarte (2009, p. 305), a memória tem a "difícil e delicada função que garante, em toda sociedade, o domínio, a preservação, a transmissão e a continuidade do significado de todas as coisas". Se para um grupo social uma praça, uma rua ou um casarão antigo são elementos representativos de suas memórias, de sua história, não adianta o Instituto do Patrimônio Histórico Artístico Nacional (IPHAN) eleger outros patrimônios oficiais se esse grupo não os reconhecem como seu.

Ao se demolir total ou parcialmente um edifício histórico, como foi feito em Santarém, para dar lugar a construções modernas que nada tem a ver com o contexto social da época ou destruir um casarão colonial para ser transformado em estacionamento, como é o caso do Casarão Tapajônico, nas opiniões do jornalista Jeso Carneiro e de uma das professoras entrevistadas, é um crime contra a sociedade.

Em artigo intitulado Preservar e Consumir: o patrimônio histórico e o turismo, Marly Rodrigues (2003, p. 17) afirma que o bem patrimonial "além de servir ao conhecimento do passado, os remanescentes materiais de cultura são testemunhos de experiências vividas, coletiva ou individualmente, e permitem aos homens lembrar e ampliar o sentimento de pertencer a um mesmo espaço". Logo, os patrimônios edificados de Santarém constituem-se em espaços de fatos representativos dos povos que ali viveram, e que ali deixaram um legado para as gerações atuais e futuras.

Para Jacques Le Goff (2003, p. 469), a memória é um elemento essencial do que se costuma chamar de identidade, seja individual ou coletiva, "cuja busca é uma das atividades fundamentais dos indivíduos e das sociedades de hoje". 
Considera-se a afirmação de Le Goff pertinente para este estudo, contudo, é necessário compreender qual ou quais as identidades de quem vive em Santarém. Será que boa parte da população tem o conhecimento de seu patrimônio, de sua cultura? Quantos passam diariamente pela frente destes patrimônio edificados e não conseguem enxergá-los, e muito menos se identificam com eles? Quantos estabelecem uma relação de pertencimento com os bens patrimoniais, o que muito contribuiria para a valoração destes?

Sobre a identidade, este tema, pela própria natureza intangível e ambivalente, Zygmunt Bauman tece algumas considerações no livro "Identidade" (2005). Para ele, na "modernidade líquida" as pessoas vivenciam um processo de transformação contínuo que segue do permanente ao transitório nas identidades sociais, culturais, profissionais, religiosas e sexuais. Ele infere que descobrir que a identidade é um monte de problemas, e não uma campanha de tema único, é um aspecto que ele compartilha com um número grande de homens e mulheres da nossa era "líquido-moderna".

Para Bauman (2005, p. 19), “as 'identidades' flutuam no ar, algumas de nossas próprias escolhas, mas outras infladas e lançadas pelas pessoas em nossa volta, e é preciso estar em alerta constante para defender as primeiras em relação às últimas". Para ele, ainda, "você assume uma identidade num momento, mas muitas outras, ainda não testadas, estão na esquina esperando que você as escolha" (Idem, p. 91).

Stuart Hall (2005) corrobora para o debate afirmando que o sujeito, outrora unificado e estático, agora encontra-se fragmentado, composto não de uma única, mas de várias identidades, por vezes contraditórias ou mal resolvidas. Para ele, o "sujeito assume identidades diferentes em diferentes momentos, identidades que não são unificadas" (HALL, 2005, p. 13).

Nessa perspectiva, qual a identidade ou identidades de quem nasceu em Santarém? É ser amazônida, paraense, santareno, mocorongo (como é chamado quem nasce em Santarém)? E quem vem de outros estados e outros países e fixam residência na cidade? Essas indagações remetem os indivíduos as suas origens, raízes e sentido de pertencimento.

A letra da música da cantora e compositora santarena Jana Figarella, Nada se Compara, dá pistas da identidade de quem nasceu em Santarém: 


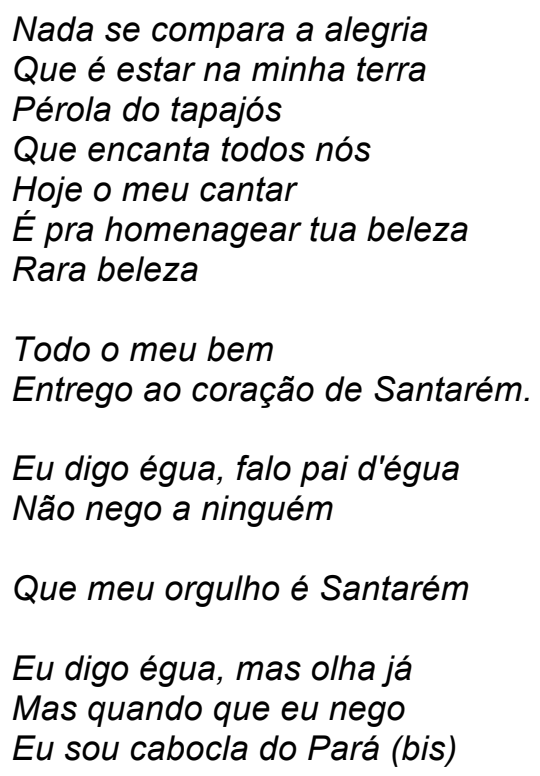

Segundo ela, a cidade possui rara beleza, e é orgulho usar a expressão "pai d'égua", ou "égua", "mas olha já", regionalismos que tornam o paraense diferente do gaúcho, por exemplo, que usa "thê" ou "Bah" ou, ainda, o "uai" dos mineiros. Para Martins (2003, p. 42), a "identidade seria, em linhas gerais, esse sentido de pertencer que as pessoas trazem enquanto seres simbólicos que são. Esse ser de algum lugar pertence a algum grupo, sente afinidade com algo que Ihe resgata algo seu".

Assim, dentro dessa perspectiva, as seguintes questões se colocam: se a memória faz parte da identidade, então obter conhecimento acerca dos patrimônios edificados de Santarém torna-se essencial para que o nativo compreenda e valorize algo que faz parte da sua história, dos seus antepassados? Por conseguinte, se essa informação chegar de forma clara, objetiva, há maiores possibilidades de mudança de atitudes e comportamentos acerca dos bens patrimoniais?

Numa caminhada pela cidade, podemos observar $o$ tempo $e$ as construções sociais dos habitantes que ali viveram, incrustradas nos muitos casarões, logradouros, igrejas, praças, museus e coreto, entre outros. "Além do casario situado na zona central da cidade, de valor histórico inegável, há edifícios monumentais como o Solar do Barão, o Teatro Vitória, e o Centro Cultural João Fona" (CARVALHO, 2012, p. 23). 
Figura 4 - Solar do Barão de Santarém

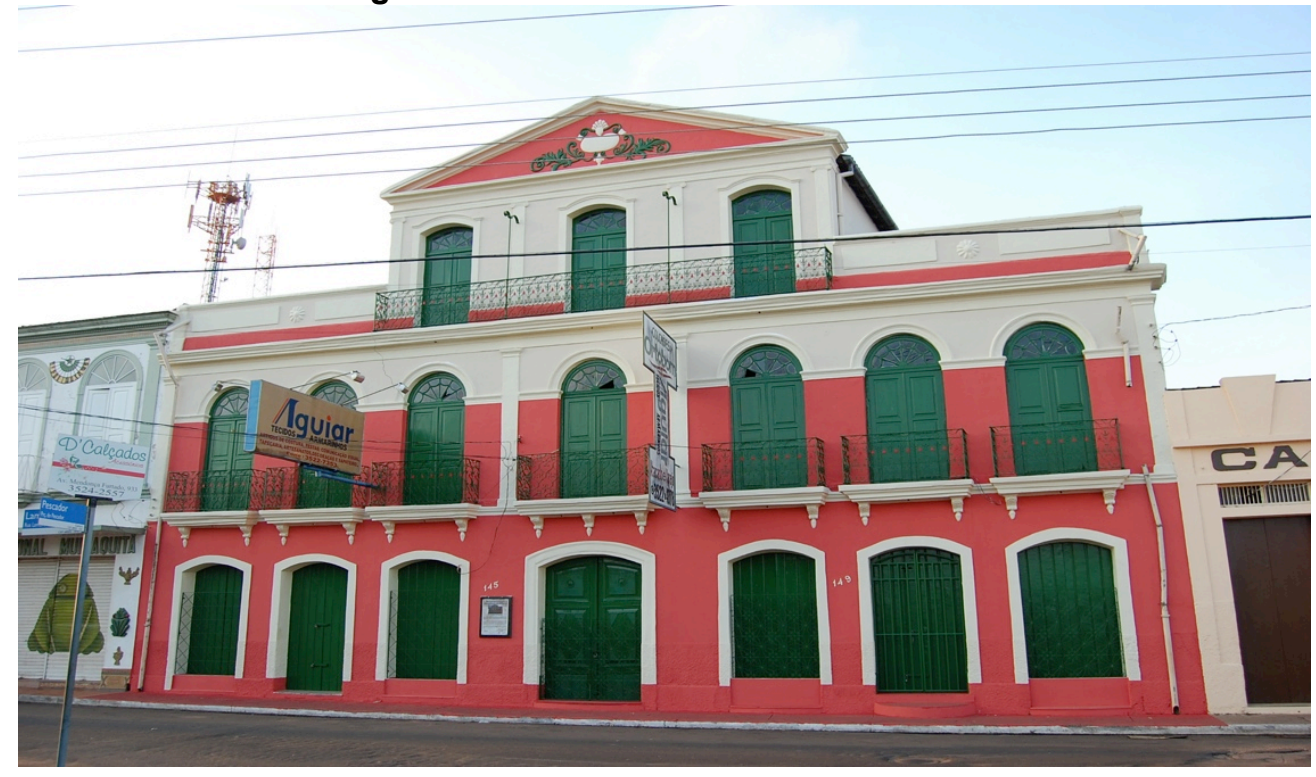

Fonte: Couto, 2013

Figura 5- Antigo Teatro Vitória

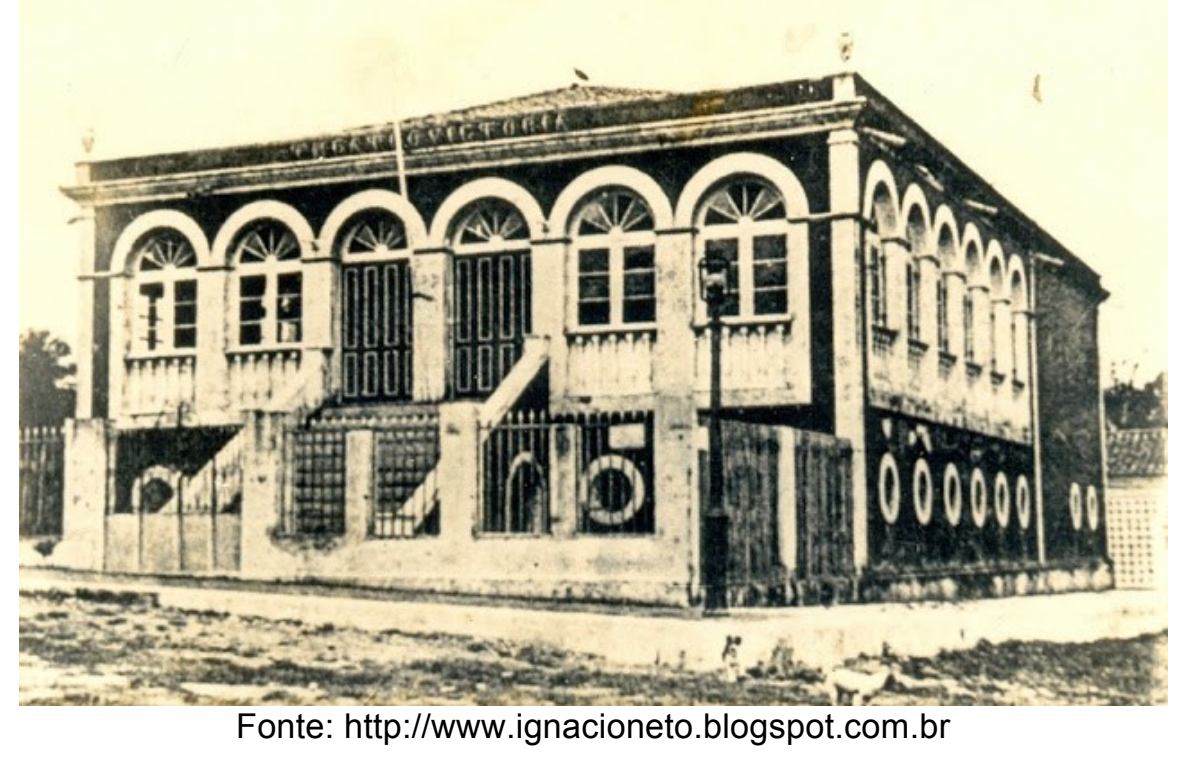




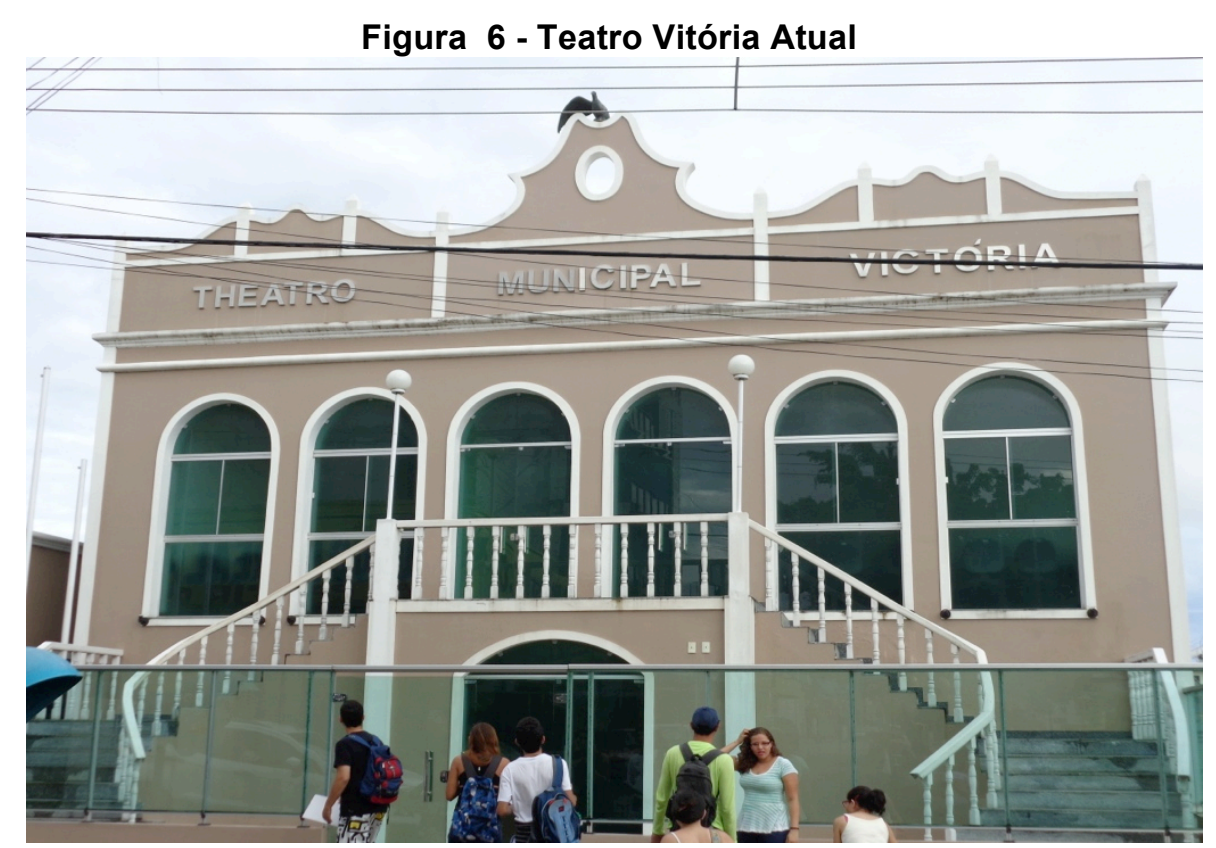

Fonte: Elias Mota

Figura 7- Centro Cultural João Fona - Museu de Santarém

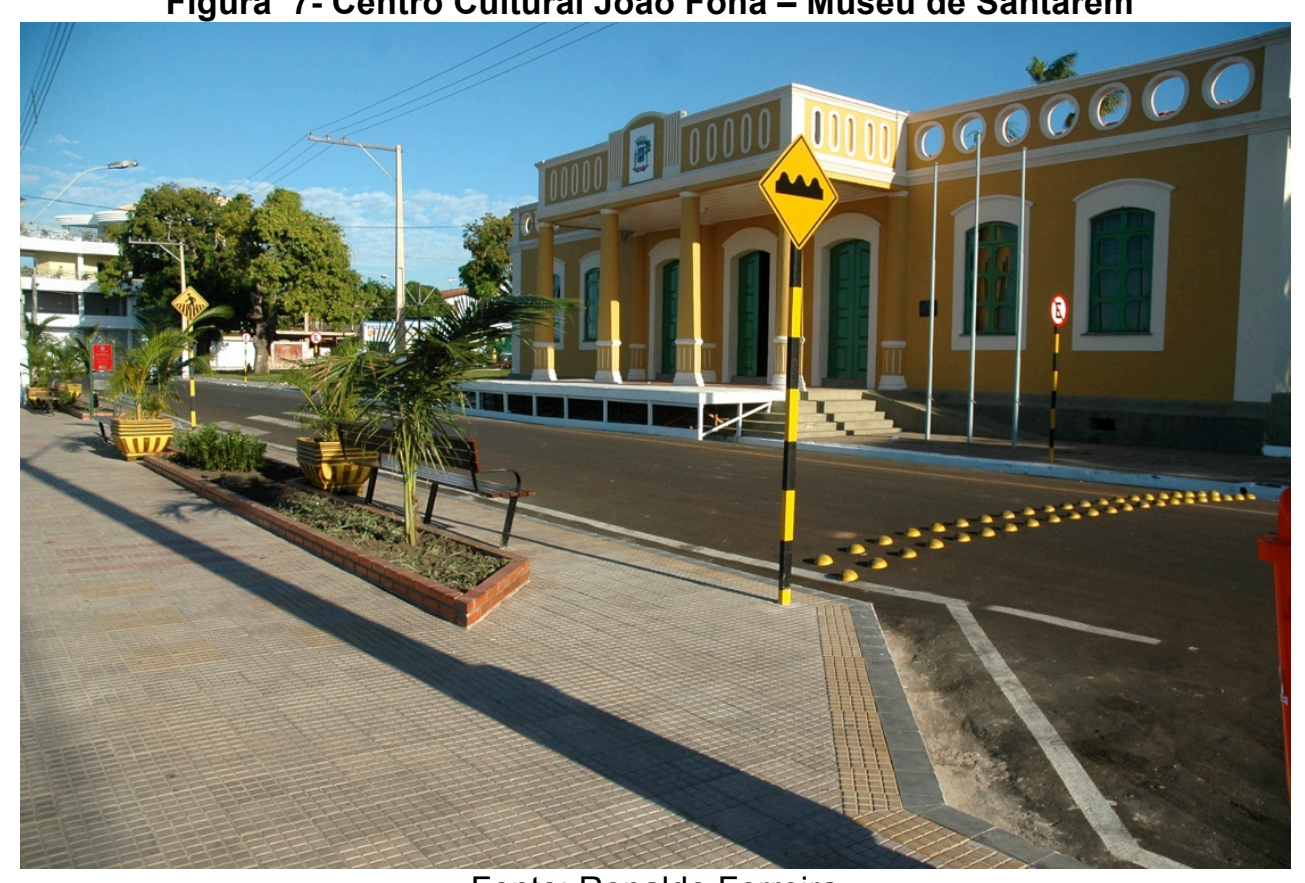

Fonte: Ronaldo Ferreira

Embora o patrimônio edificado da cidade esteja espraiado por toda a zona urbana, para efeito desta pesquisa, nos concentraremos no Centro Histórico de Santarém. O Centro Histórico da Cidade compreende a área situada entre a Praça Barão de Santarém (Trav. Nazaré - Prainha) e a Praça Rodrigues dos Santos (Trav. João Otaviano de Matos - Centro). Esta área concentra a maioria dos bens 
patrimoniais edificados em Santarém, porém, vale ressaltar a existência de outros patrimônios que, conforme a necessidade do estudo em tela, serão citados no decorrer da pesquisa.

Figura 8- Centro Histórico de Santarém

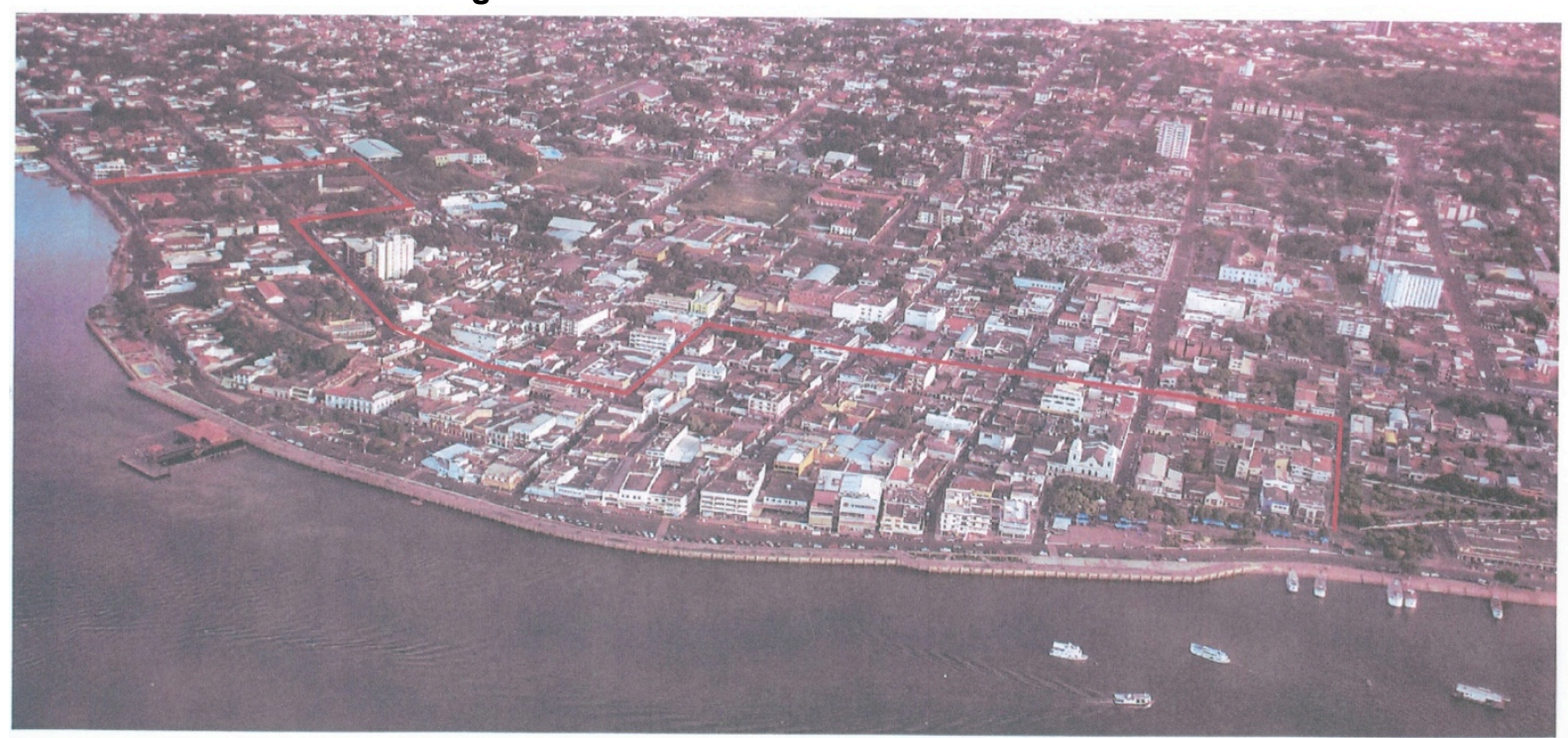

Fonte: PLANO DE AÇÃO DAS CIDADES HISTÓRICAS SANTARÉM - PARÁ 2010/2013.

O Centro Histórico de Santarém constitui-se em um valioso bem patrimonial que vem sendo descaracterizado e, muitas vezes, esquecido tanto pelo poder público, como por parte dos moradores da cidade. Esse fato se torna preocupante, pois como nos diz Lúcio Flávio Pinto, no prefácio da obra Tupaiulândia (1999, p. 4): "um povo sem referências consistentes (ou de qualquer qualidade mesmo) sobre seu passado está condenado a não ter futuro".

Observa-se que, infelizmente, uma grande parcela da população encontrase indiferente às questões de conservação e preservação do patrimônio edificado da cidade. Talvez, por falta de informação ou sensibilização. Por outro lado, existe um grupo de pessoas ligado à cultura que mostra grande interesse em mudar esse cenário de descaso, cobrando do poder público ações concretas de combate ao que vem ocorrendo com o Patrimônio Edificado de Santarém, a exemplo, é o que ocorreu em setembro de 2014, conforme será destacado, posteriormente.

Sobre o descaso com o Patrimônio Edificado, a historiadora Terezinha Amorim se posicionou da seguinte forma: "lamentavelmente, observa-se que a cada dia o número de construções antigas que constituem o patrimônio edificado 
da cidade vem diminuindo. Prédios históricos vão sendo descaracterizados, demolidos, encobertos por fachadas e tapumes" (AMORIM, 2012, p. 42).

A mesma autora afirma que:

Gradativamente, o processo de transformação socioeconômica e política da cidade, aliada ao descaso e a construção de novas edificações, estão provocando o desaparecimento dos bens edificados e monumentos de grande valor arquitetônico e histórico, alterando o panorama da Santarém Antiga, elementos essenciais para a compreensão da história da nossa cidade e que traziam consigo um conjunto de significados dos diferentes períodos da formação histórica e cultural da sociedade e de seus moradores (AMORIM, 2012, pp. 43-44).

Alguns Patrimônios Edificados de Santarém que sofreram descaracterização e outros que foram preservados são exemplos da boa e má utilização do bem patrimonial na cidade. 
Figura 9- Antigo Casarão da Família Campos Corrêa

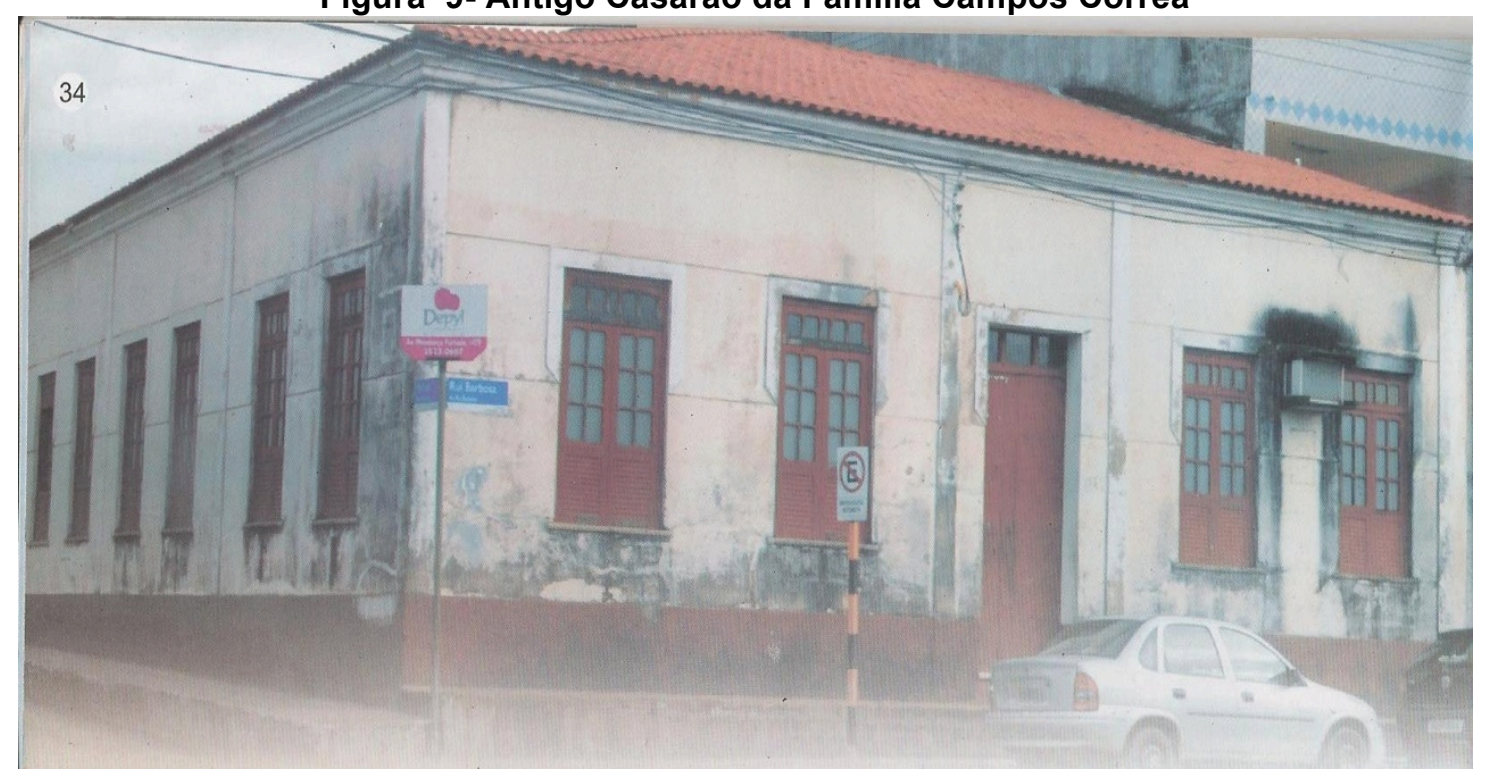

Fonte: Revista Patrimônio Histórico e Arquitetônico de Santarém, 2010

Figura 10 - Antigo Casarão da Família Campos Corrêa descaracterizado

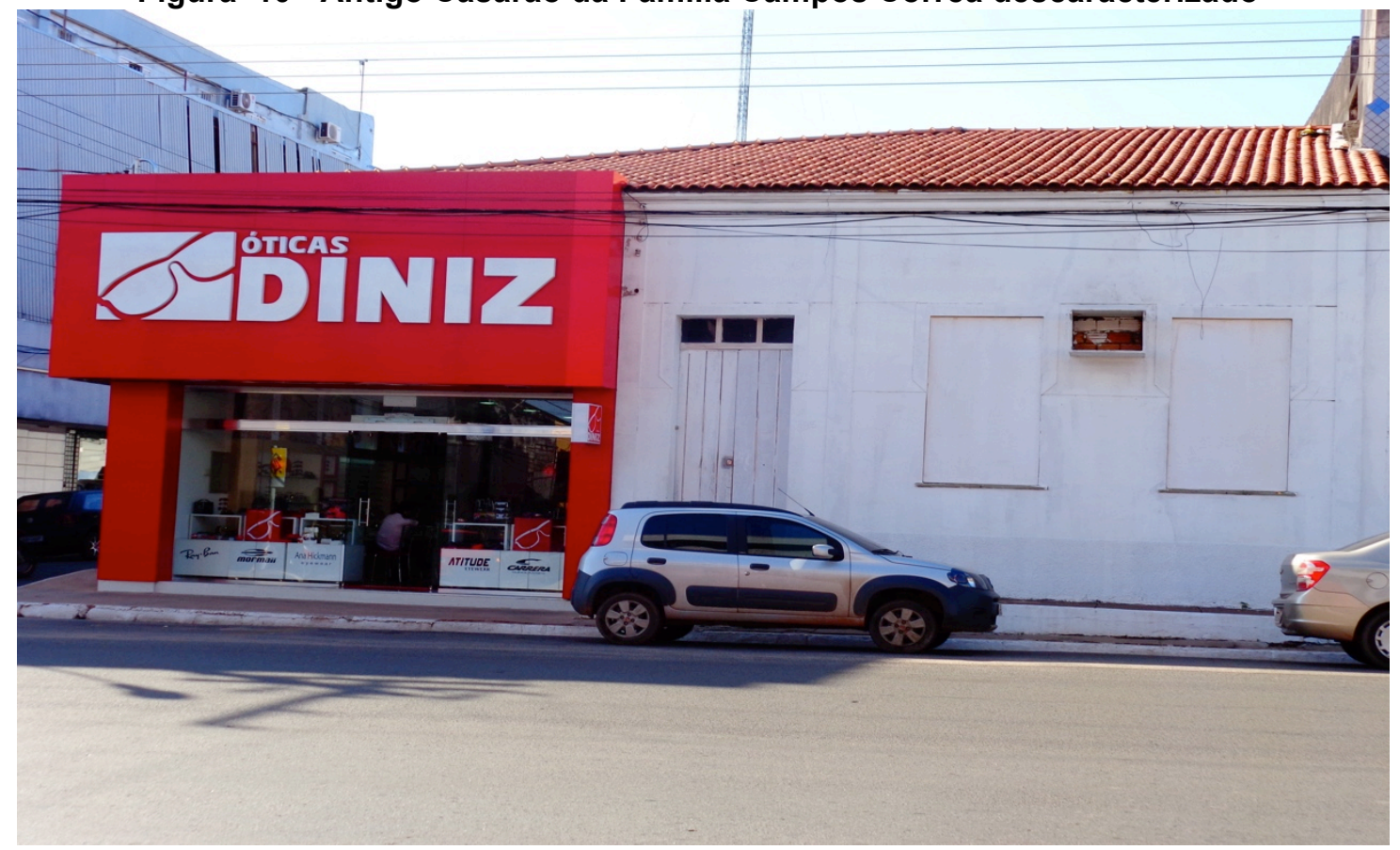

Fonte: Elias Mota 
Figura 11- Sobrado conhecido popularmente como Castelinho Séc. XIX/Casa dos Gonçalves

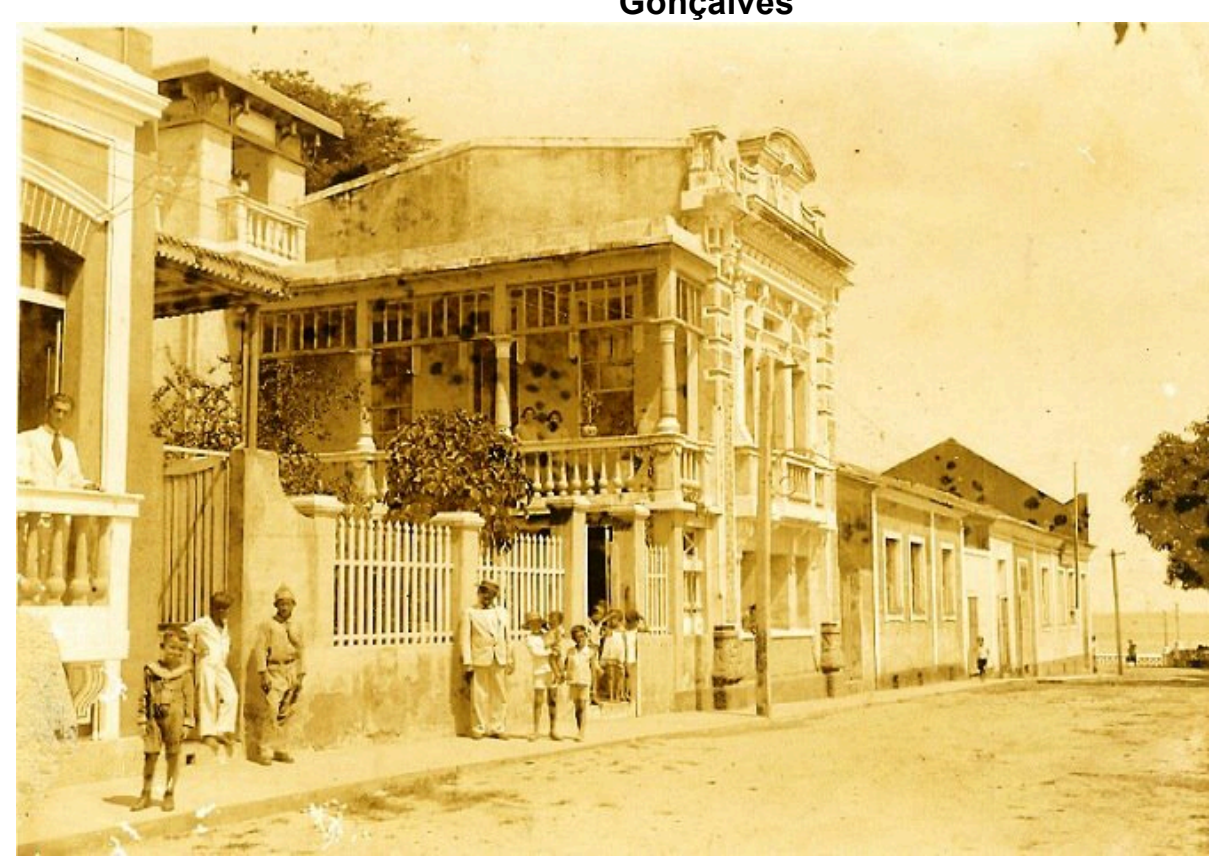

Fonte: http://www.ignacioneto.blogspot.com.br

Figura 12 - Sobrado Castelinho/Casa dos Gonçalves na atualidade

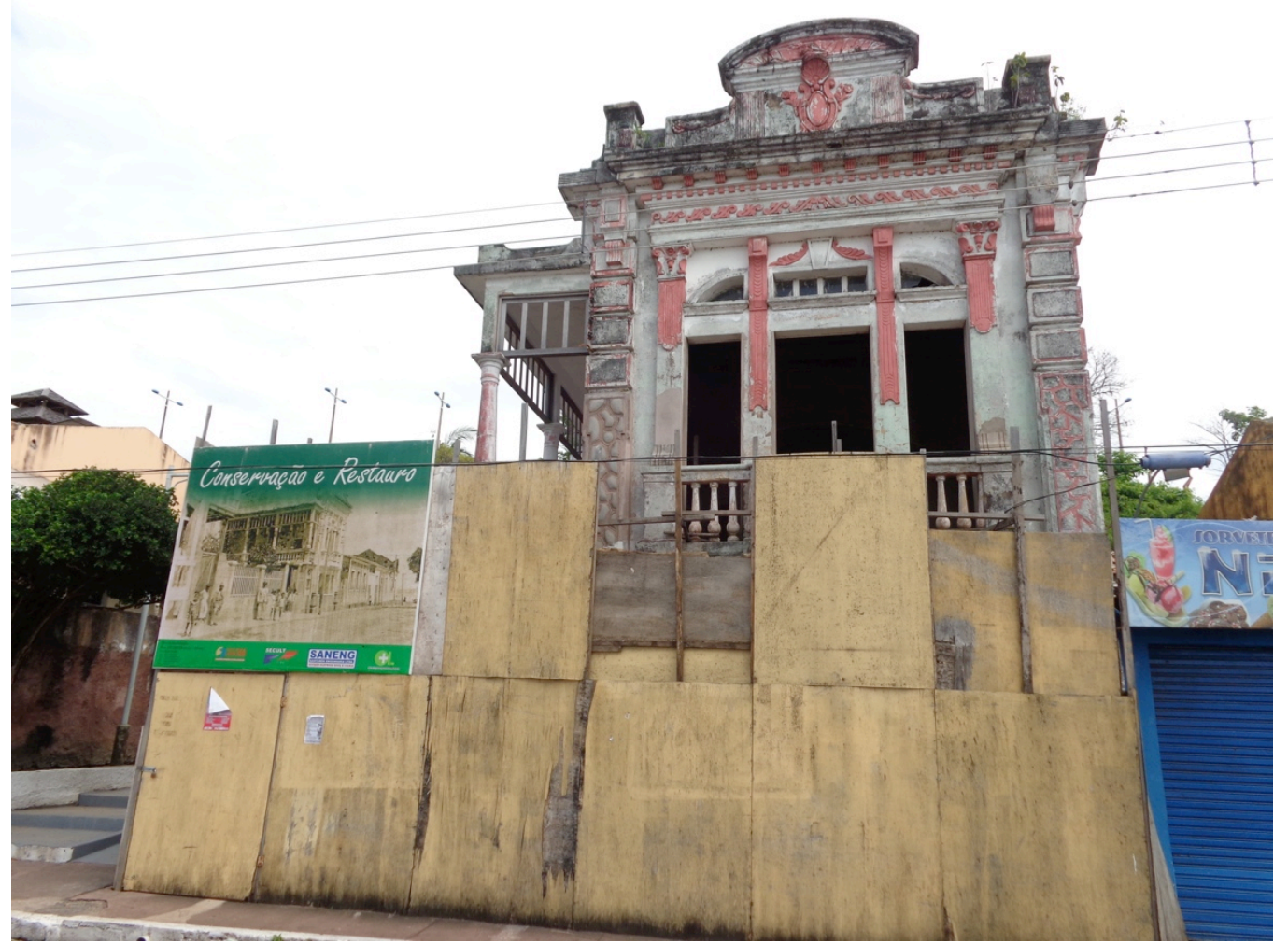

Fonte: Elias Mota

Porém, nem tudo está perdido, existem aqueles que têm o cuidado de preservar e conservar o bem patrimonial sem descaracterizá-lo, contribuindo, dessa forma, para a história e memória da cidade, como, por exemplo, o prédio 
denominado Solar dos Brancos que foi totalmente recuperado por seu atual proprietário, senhor Francisco Aguiar. Em estilo eclético, este belíssimo Patrimônio Edificado foi construído no final do século XIX, em três pavimentos.

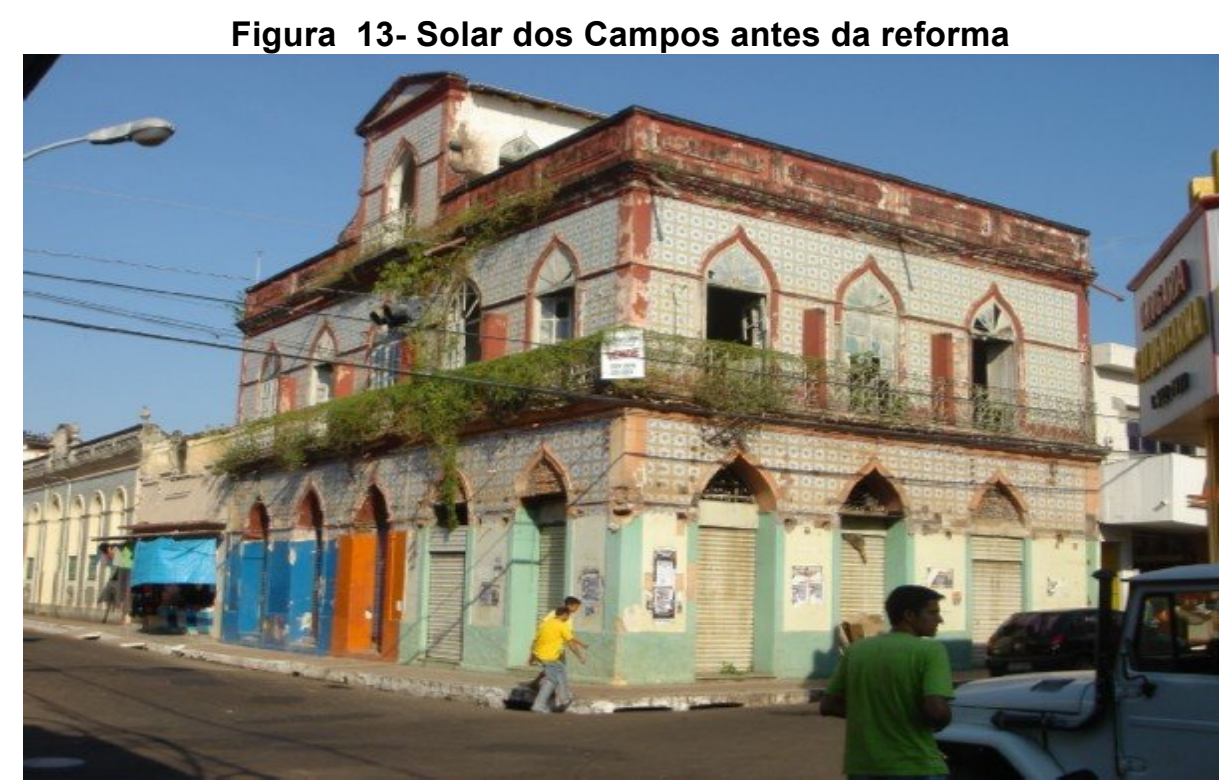

Fonte: Couto, 2013.

Figura 14- Solar dos Campos na atualidade

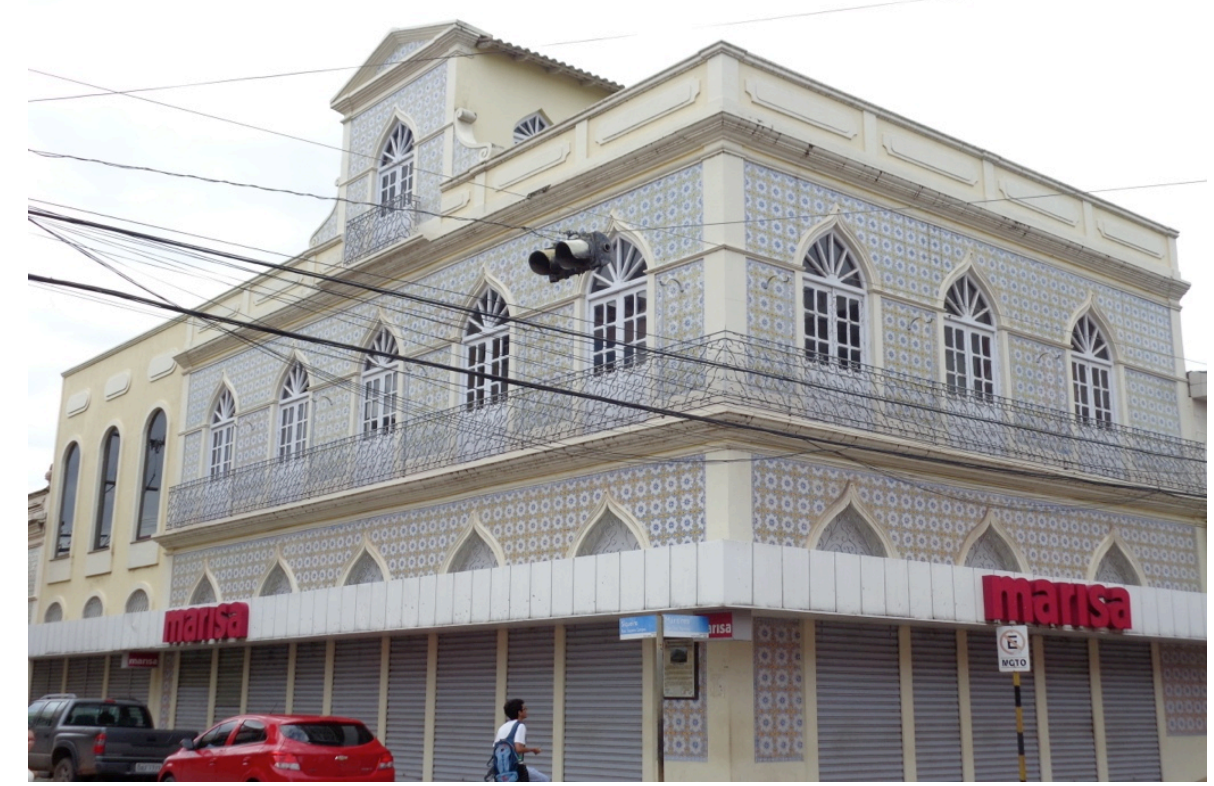

Fonte: Elias Mota 
Figura 15- Patrimônio Edificado em bom estado de conservação

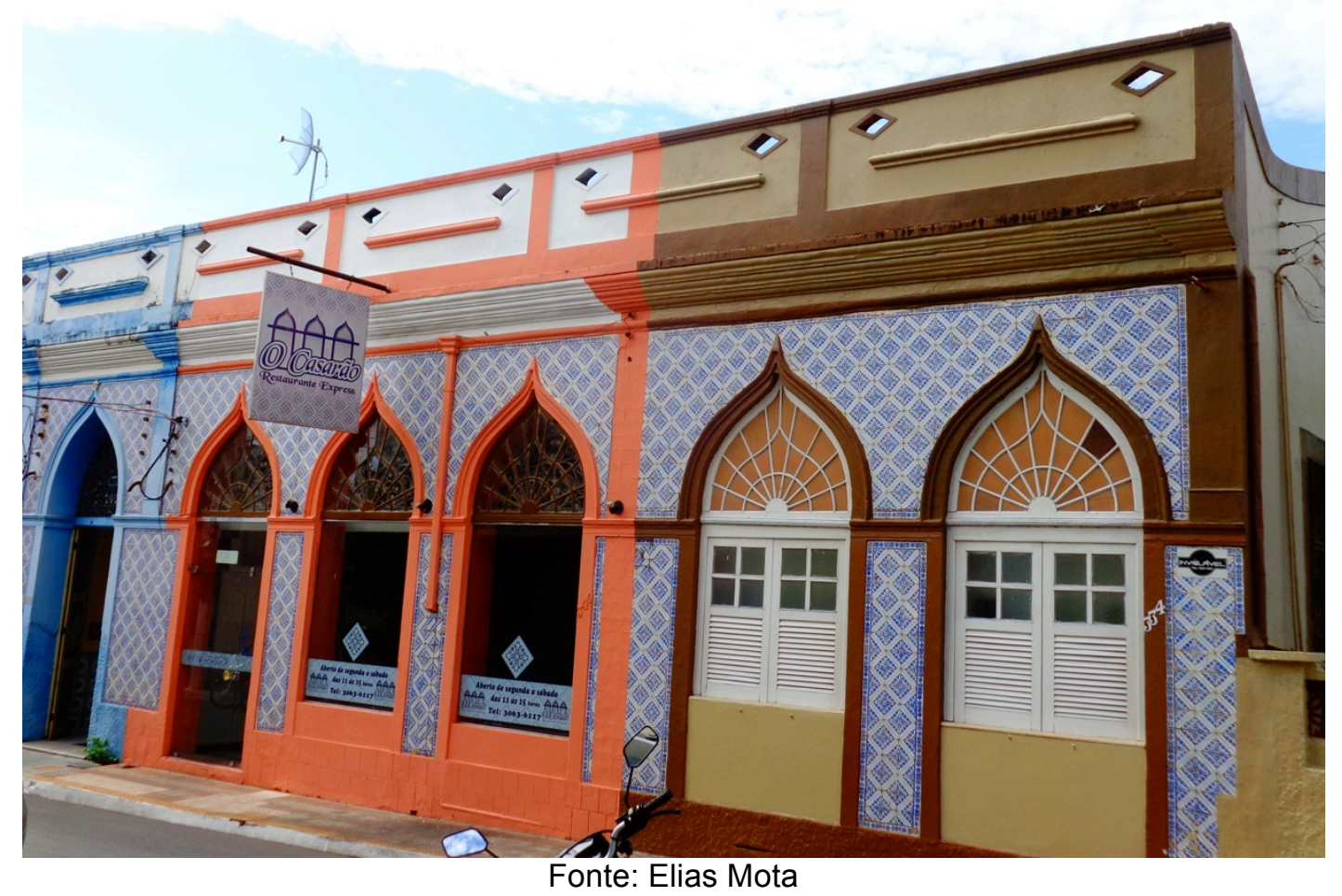

Mas, o descaso com o Patrimônio tornou-se regra e não exceção em Santarém. O fato mais recente desse descaso com o bem patrimonial aconteceu, em setembro de 2014, com o "Casarão Tapajônico", também conhecido como o "Casarão dos Macambiras", importante construção em estilo colonial que teve sua parte interna toda demolida para construção de um estacionamento. Tal fato gerou grande repercussão na cidade. Houve intensa mobilização da sociedade local e repúdio a total falta de descaso dos órgãos competentes. Vários segmentos da sociedade civil articulados pelo Movimento Arte e Cultura de Santarém, através das redes sociais, estiveram representados: Associação do Teatro Amador de Santarém - ATAS, professores, representantes de ONG, representantes da Ordem dos Advogados do Brasil - OAB, cantores locais, estudantes, dentre outros. Se organizaram e fizeram uma manifestação, um ato simbólico, por meio de uma caminhada pelo Centro Histórico da Cidade, com paradas em frente à antiga "Casa de Saúde de Santarém", Panificadora Lucy, até chegar em frente ao Casarão, usando roupas pretas e velas que simbolizavam o funeral da referida edificação. 


\section{Uma das idealizadoras do Ato Simbólico, a cantora e compositora santarena Cristina Caetano, assim se pronunciou em uma rede social:}

Diante do descaso com a cultura em nossa cidade e principalmente com os tristes acontecimentos de destruição do Casarão Tapajônico e do prédio da antiga Padaria Lucy resolvemos fazer um "Cortejo Fúnebre" em forma de protesto pela omissão de nossos governantes que não cuidam de nosso patrimônio. Precisamos mostrar que Cultura é fundamental e precisa ser prioridade em qualquer governo e atrelada a educação [...] Não queremos um estacionamento com a cara do Casarão Tapajônico. Isso é uma vergonha e afronta para a sociedade!!! ${ }^{5}$

\section{O presidente da Academia de Letras e Artes de Santarém (ALAS),}

Edinaldo Rodrigues, também demonstrou apoio ao movimento em defesa do Patrimônio Cultural da Cidade.

Na condição de membro ativo do movimento cultural de Santarém há mais de 30 anos e com a responsabilidade de atual Presidente da Academia de Letras e Artes de Santarém (ALAS) venho me juntar a todos para manifestar o posicionamento da ALAS contra o descaso, contra a dilapidação do Patrimônio Histórico e Cultural, contra o desrespeito e a indiferença da gestão pública nas instâncias Estadual e Municipal aos segmentos culturais e a cultura TAPAJÔNICA [...] Hoje, a cultura santarena está diante de um dos maiores ostracismos de sua história. Vejamos nós: o Patrimônio Histórico e Arquitetônico está virando pó todos os dias [...] Por isso, vamos nos integrar ainda mais ao movimento cultural de Santarém e da região. Juntos vamos defender a arquitetura, a música, a literatura/poesia, o teatro, a dança, o artesanato, a escultura e todas as manifestações culturais. ${ }^{6}$

\footnotetext{
${ }^{5}$ Fragmento retirado do Facebook, Grupo Ato Simpólico - Cortejo Fúnebre - contra a destruição do Patrimônio Arquitetônio, Paisagístico, Hitórico e Cultural de Santarém - Movimento. Postado em 21 de setembro de 2014. Disponível em: https://www.facebook.com/events/499798496824014/.

${ }^{6}$ Fragmento de texto retirado, de autoria de Ednaldo Rodrigues, retirado do Blog do Jeso. Publicado em 21 de setembro de 2014. Disponível em: http://www.jesocarneiro.com.br/artigos/em-defesa-dacultura-santarena.html
} 
Figura 16- Fachada do Casarão Tapajônico

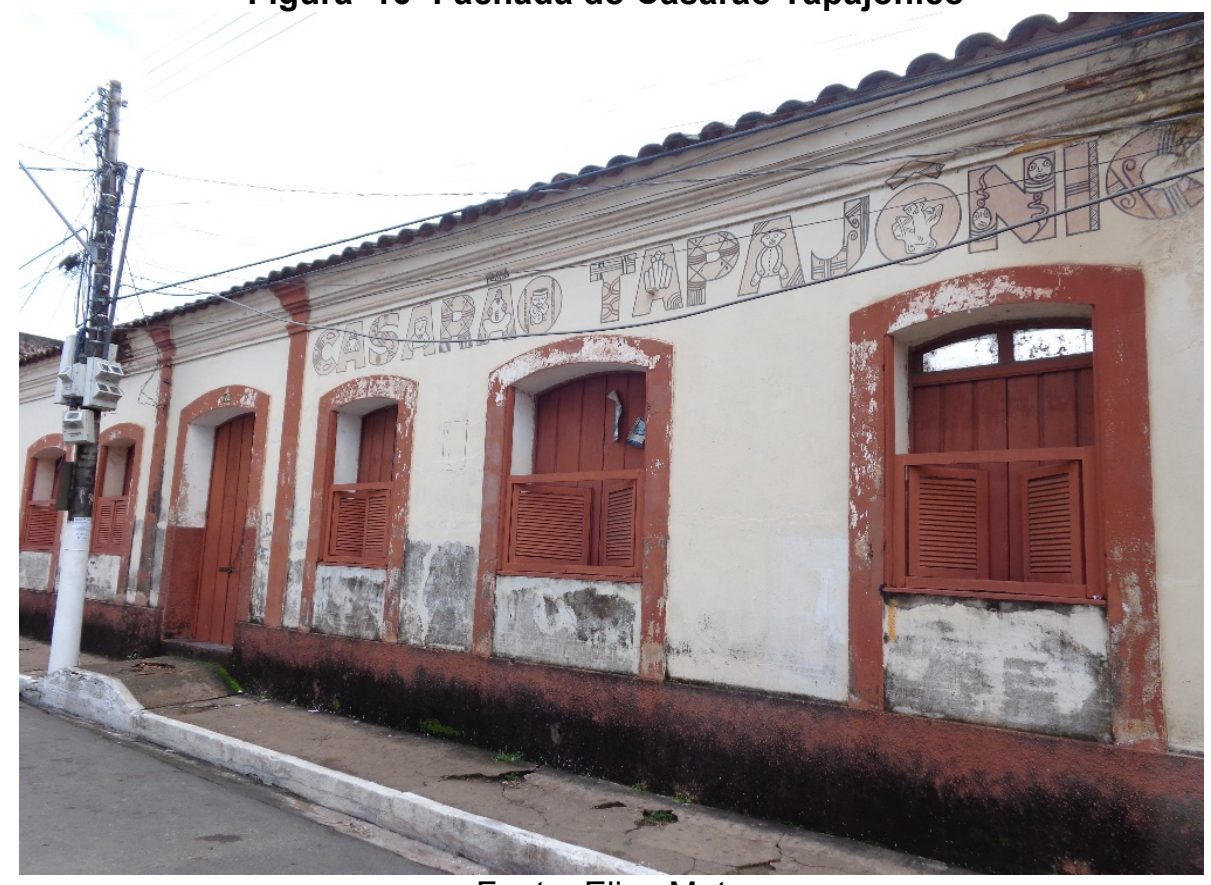

Fonte: Elias Mota

Figura 17- Parte Interna do Casarão Tapajônico totalmente demolida

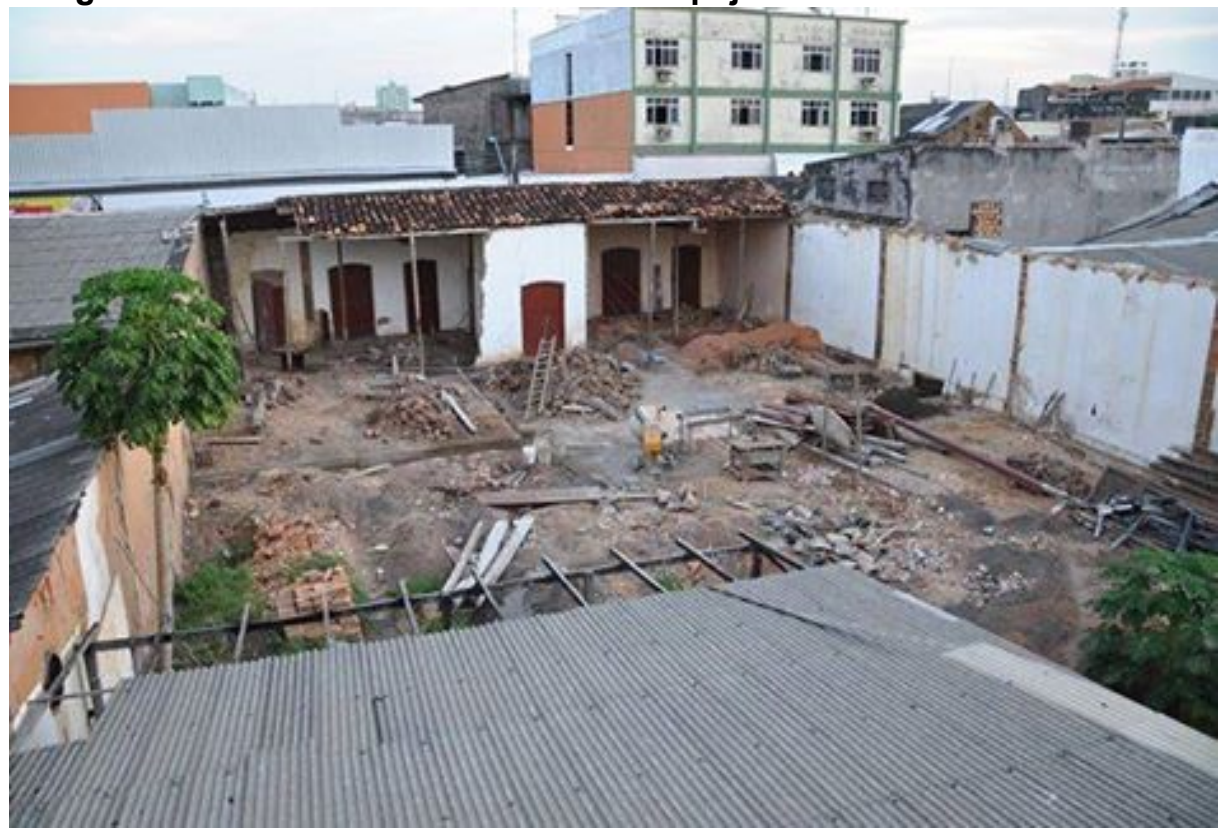

Fonte: Ítala Nepomuceno 
Figura 18 - Ato simbólico em frente à fachada da antiga Padaria Lucy

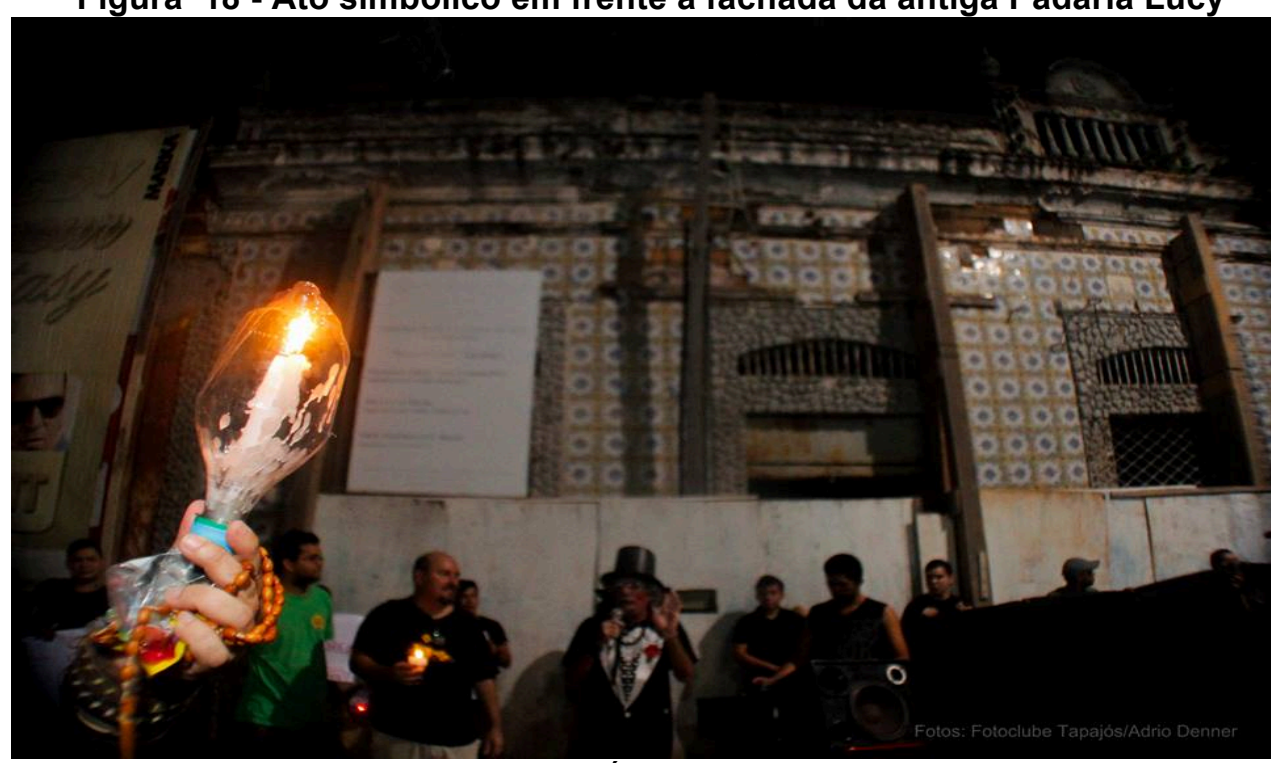

Fonte: Ádrio Dener

Tanto o Casarão Tapajônico, a antiga Padaria Lucy, o Casarão dos Reça, com também a demolição total da antiga Casa de Saúde de Santarém (Casa de Saúde São Sebastião) são exemplos do total descaso em relação aos Patrimônios Edificados da Cidade. Em conversa com uma técnica do Instituto do Patrimônio Histórico e Artístico Nacional (IPHAN), a arquiteta Tatiana Carepa Roffé, em Belém do Pará, em outubro de 2013, o pesquisador foi informado sobre a situação em que se encontra o Patrimônio Edificado em Santarém:

\begin{abstract}
A situação com que se encontra o patrimônio histórico em Santarém é preocupante, de todo o acervo edificado o único que está em processo inicial de tombamento pelo IPHAN é o Centro Cultural João Fona, infelizmente as questões referentes aos bens patrimoniais não avançam por lá, a impressão que temos é que todas as vezes que retornamos a Santarém, encontramos um prédio a menos.
\end{abstract}

Essa afirmação demonstra o real estado em que se encontra a questão da preservação e conservação dos bens patrimoniais da cidade. Se não há leis que amparem esses patrimônios, pouco se pode fazer de oficialmente concreto em Santarém, na atualidade. 
Figura 19 - Fachada da antiga Padaria Lucy

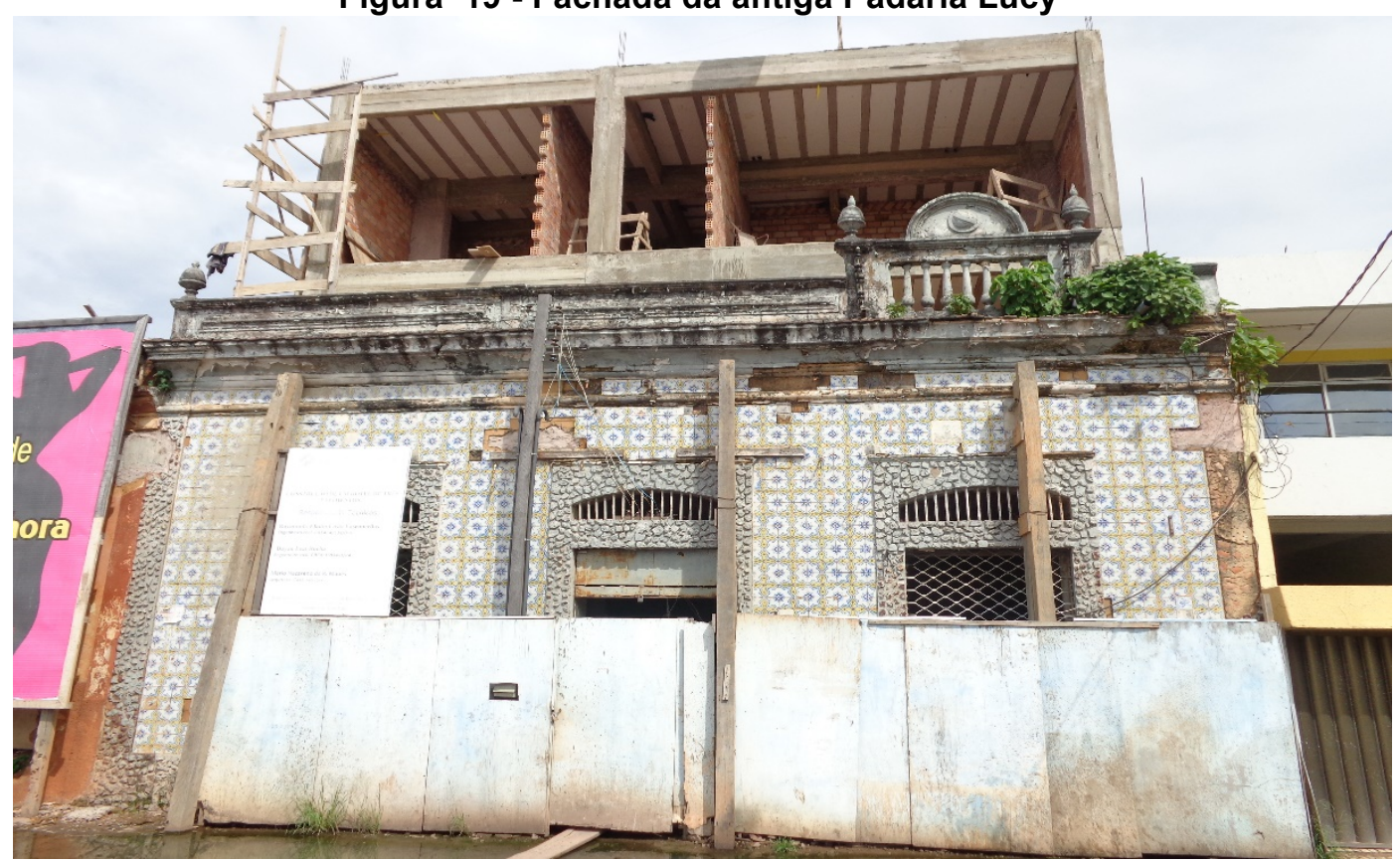

Fonte: Elias Mota

Figura 20- Detalhe da fachada da Padaria Lucy e azulejos portugueses do interior

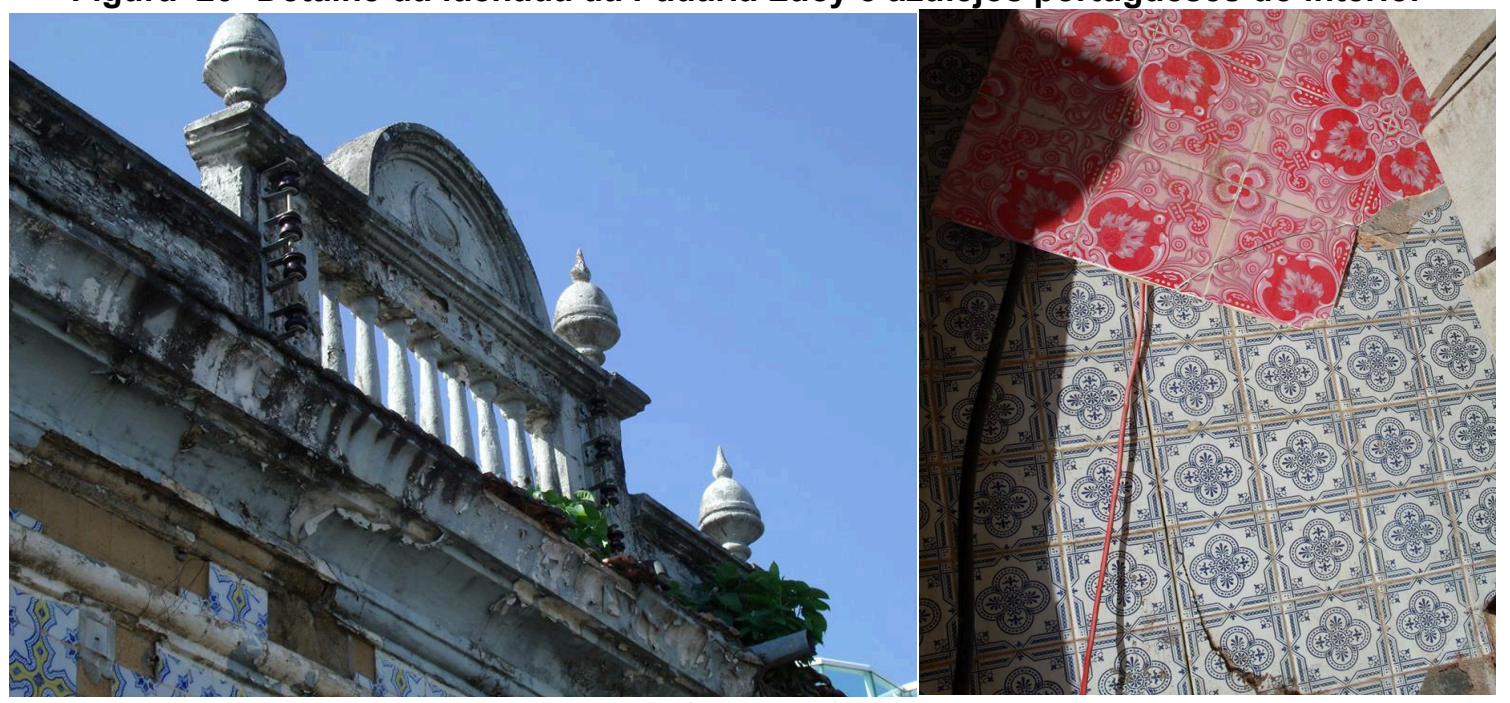

Fonte: Christian Soares 
Figura 21 - Construção na parte interna da antiga padaria Lucy ao lado direito o que restou do antigo Casarão dos Reça

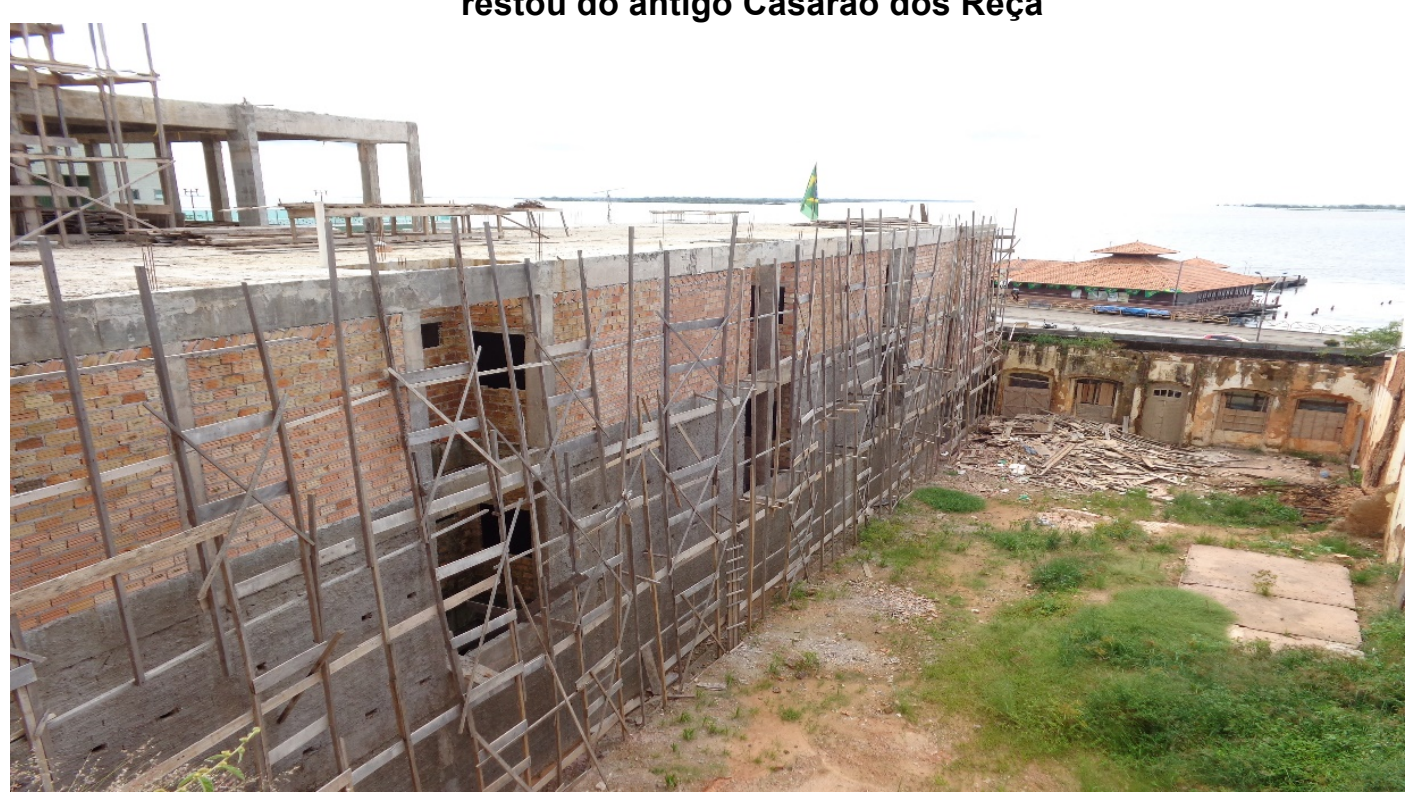

Fonte: Elias Mota

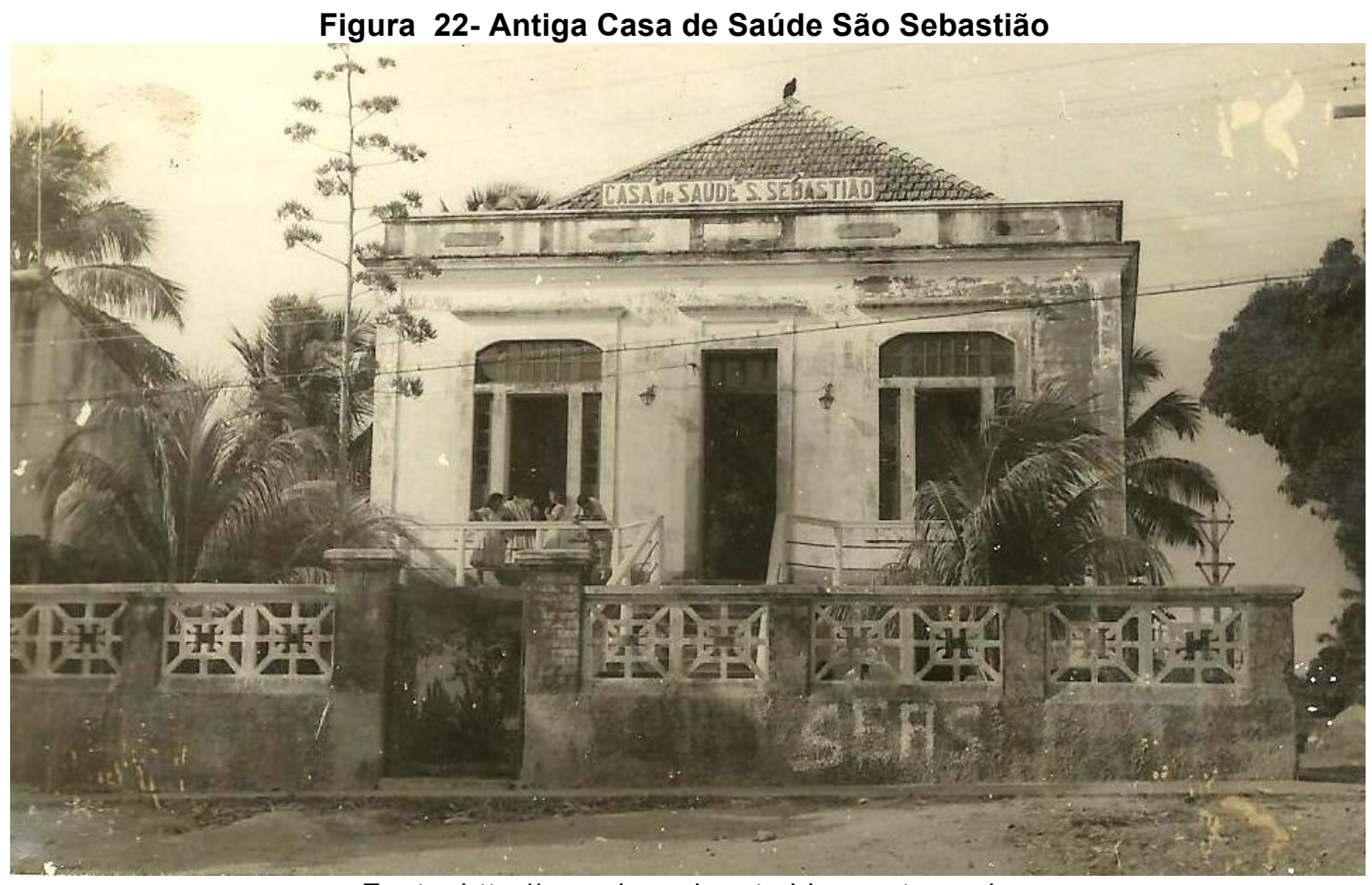

Fonte: http://www.ignacioneto.blogspot.com.br 
Figura 23 - Terreno onde ficava a Casa de Saúde São Sebastião

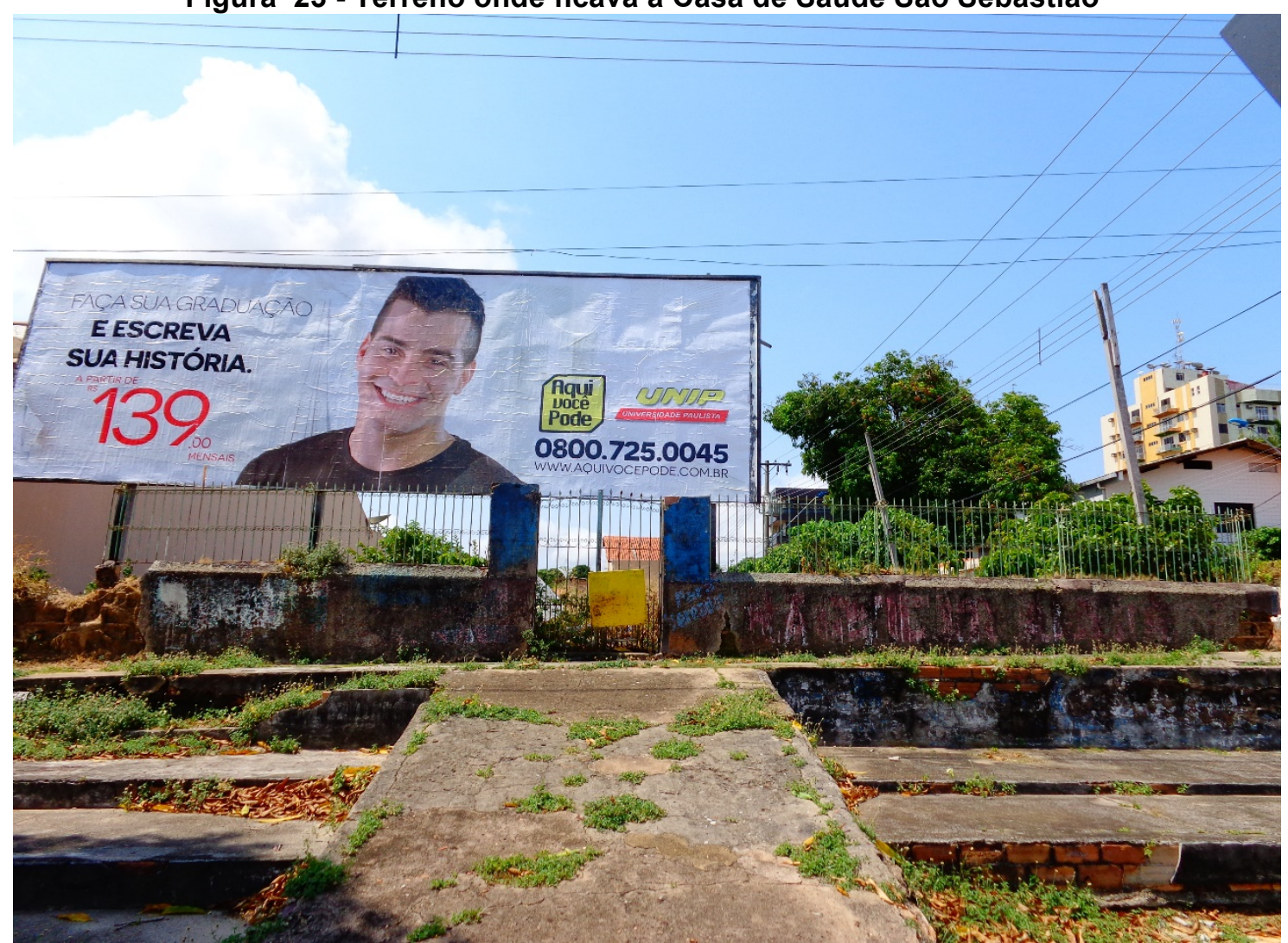

Fonte: Elias Mota

Em setembro de 2011, vários leitores do "Blog do Jeso" manifestaram suas opiniões acerca do que aconteceu com o prédio da antiga Padaria Lucy, que teve toda sua estrutura interna demolida, restando somente a fachada em pé.

Estou lagrimando junto com todos aqueles que provaram do melhor pão de Santarém, isso é uma prova de que a Pérola do Tapajós está ficando sem memória (Pajé Goró).

Sempre que vou ao Rio de Janeiro, "mato" um pouco da saudade da Padaria Lucy, indo na Confeitaria Colombo, no centro do Rio. A Padaria Lucy, não tinha o glamour da Colombo, mas alguns azulejos e os biscoitos deliciosos refrescam a memória dos saudosistas. Os barcos vindo de Alenquer encostavam na frente da Padaria Lucy e antes de sair para fazer os exames médicos, pois só íamos à Santarém pra fazer algum tratamento de saúde, a padaria Lucy era nossa parada obrigatória. Até hoje não sei o nome do meu biscoito preferido, sei apenas que lembra uma empada doce com um "pingo" de goiabada no meio. Jamais poderia imaginar que tudo terminasse assim... (Ximango da Gema)

Ver essas fotos da antiga padaria Lucy neste estado lamentável foi com ver parte da minha infância quebrada (Marcelo).

\footnotetext{
${ }^{7}$ O Blog do Jeso existe a mais de dez anos e tem como editor o jornalista Jeso Carneiro, é muito respeitado em toda a região oeste do Pará, constituindo-se como "formador de opinião". Endereço do Blog: http://www.jesocarneiro.com.br/artigos/em-defesa-da-cultura-santarena.html.
} 
Infelizmente a lógica do capital se faz mais 'racional' (à força) do que manter a memória de uma cidade e de um povo. Quando li os comentários sobre a padaria, de histórias pueris, de relatos de viagens, é incontestável que esse imóvel tem mais valor de identidade, do que arquitetônico. Apesar de tanta tecnologia, de fotografia, vídeos e impressoras 3d, nada é mais importante do que a sentir a espacialidade desse monumento. Ainda há tempo de não se deixar perder uma parte da nossa gente, de nossa história (Anisio Quincó).

Me lembro que quando criança, costumava ficar girando naqueles bancos brancos, rss. E sempre que podia, me pesava naquela balança enorme que lá tinha. E o olho de boi, o sorvete de cupuaçu então? Saudades de um tempo que não volta mais. Tive pelo menos a felicidade, de durante a minha infância ir na padaria Lucy" (Sara).

Através dos depoimentos supracitados, fica evidente a indignação, o repúdio e o descontentamento das pessoas que tiveram suas vidas marcadas de alguma forma por esse Patrimônio Edificado.

Choay (1996), citada por Sant'anna (2009, p. 49), destaca que "o monumento trabalha e mobiliza a memória coletiva por meio da emoção e da afetividade, fazendo vibrar um passado selecionado, com vistas a "preservar a identidade de uma comunidade étnica, religiosa, nacional, tribal ou familiar”. Já Funari e Pelegrini (2009, p. 35) sustentam que "a memória da cidade se expressa mediante a conservação dos estilos arquitetônicos do casario, das igrejas, dos edifícios públicos e monumentos, no contexto de suas respectivas paisagens culturais".

Jeudy (1990, p. 16) afirma que "a memória coletiva é trabalhada em meio à ameaça de seu próprio desaparecimento", fato que aconteceu com a antiga Padaria Lucy e outros Patrimônios Edificados em Santarém. O autor sustenta ainda que a memória da cidade é, por um lado, monumental e dela fazem parte a catedral, uma hospedaria e, por outro, ela é cotidiana, vivida nos percursos de ruas e praças. Sandra Jatahy Pesavento (2012) corrobora ao afirmar que a memória de uma cidade se apoia na materialidade, nas vivências e na sensibilidade do vivido.

Parafraseando Halbwachs, Barreto (2007, p. 134) infere que:

O conceito de memória coletiva tem a ver com uma memória social, exterior ao indivíduo, estendida no tempo, que guarda arquivados fatos acontecidos há muito. Essa memória é o invólucro das memórias individuais e conserva, à sua maneira, os fatos que aconteceram na sociedade à qual o indivíduo pertence. Os indivíduos, por sua vez, precisam dessa memória coletiva quando desejam saber sobre fatos que 
não testemunharam e que fazem parte do seu passado e da comunidade a que pertencem.

Pierre Nora (1993, p. 14), em seu texto Entre memória e história: a problemática dos lugares, afirma que "o sentimento de um desaparecimento rápido e definitivo combina-se à preocupação com o exato significado do presente e com a incerteza do futuro para dar ao mais modesto dos vestígios, ao mais humilde testemunho a dignidade virtual do memorável".

Dessa forma, a cidade precisa que seu morador, visitantes e turistas tenham sensibilidade em relação à importância de se preservar e conservar seu Patrimônio Histórico e Cultural, tais como os elencados neste estudo - casarões, logradouros, praças, museus, igrejas, coreto, teatro, centro cultural, entre outros -, contribuindo, dessa forma, para que a história e a memória ${ }^{8}$ de Santarém não fiquem guardadas apenas em fotos e em livros, mas sejam objetos de apropriação e pertença de sua gente.

Acerca dessa discussão, o padre e coordenador da Comissão de Justiça e Paz da Diocese de Santarém, Edilberto Sena, publicou o artigo Colônia, culto e cultura, em 19/11/2014, no "Blog do Jeso", onde declarou que o "povo que não cuida de seu passado cultural, que permite a destruição de seus símbolos de identidade, é fadado a ser colonizado perpetuamente".

A categoria Patrimônio estava ligada, no passado, à aquisição de bens e à herança $^{9}$ deixada/transmitida de alguém a outrem. Ao longo da história, houve uma ressignificação e, na atualidade, engendra uma infinidade de significados, quais sejam: patrimônio econômico, financeiro, imobiliário, cultural, arquitetônico, histórico, artístico, etnográfico, ecológico, genético e, recentemente, reconheceuse a categoria imaterial ou intangível. Portanto, estamos diante de uma palavra polissêmica e inerente à condição humana, há muitos anos ${ }^{10}$. Como afirma Gonçalves (2009, p. 25), "parece não haver limite para o processo de qualificação dessa palavra".

\footnotetext{
${ }^{8}$ Segundo Nora (1993, p. 9), "a memória é a vida, sempre carregada por grupos vivos e, nesse sentido, ela está em permanente evolução, aberta à dialética da lembrança e do esquecimento, inconsciente de suas deformações sucessivas, vulnerável a todos os usos e manipulações, susceptível de longas latências e de repentinas revitalizações [...] ela é um fenômeno sempre atual, um elo vivido no eterno presente [...] ela se alimenta de lembranças vagas, telescópicas, globais ou flutuantes, particulares ou simbólicas, sensível a todas as transferências, cenas, censura ou projeções [...] a memória emerge de um grupo que ela une".

${ }^{9}$ Ver Choay (2006); Barretto (2000); Oliveira (2008); Rodrigues (2003); Poulot (2009); Chuva (2009).

${ }^{10}$ Para Poulot (2009, p. 12), "a história do Patrimônio é amplamente a história da maneira como uma sociedade constrói seu patrimônio".
} 
Para Oliveira (2008), quando se fala em Patrimônio, fala-se também de história, memória e identidade, categorias inter-relacionadas, cujos conteúdos são definidos e modificados ao longo do tempo.

Conforme Françoise Choay (2006, p. 11):

A expressão patrimônio histórico designa um bem destinado ao usufruto de uma comunidade que se ampliou a dimensões planetárias, constituindo pela acumulação contínua de uma diversidade de objetos que se congregam por seu passado comum: obras e obras-primas das belas artes [...] trabalhos e produtos de todos os saberes dos seres humanos.

Margarita Barretto (2000) afirma que o Patrimônio pode ser classificado em duas grandes divisões: natural e cultural. Partindo-se desta perspectiva, pode-se aferir que o Patrimônio Natural de Santarém é muito conhecido nacional e internacionalmente, principalmente por conta da beleza cênica de sua natureza, das muitas praias de água doce e areia branca que a cidade possui, com ênfase maior para a praia de Alter do Chão, distante do centro da cidade, aproximadamente, $35 \mathrm{~km}$. É conhecida como "Caribe Brasileiro" ou "Caribe Amazônico" e recebe, todos os anos, tanto na época de cheia com na de vazante, milhares de turistas. O jornal britânico The Guardian ${ }^{11}$ elegeu, pela segunda vez, a praia de Alter-do-Chão como uma das oito melhores do Brasil, em 2012. Além de Alter do Chão, existem quilômetros de praias às margens do Rio Tapajós, como, a não menos bela, Ponta de Pedras.

Merece destaque, ainda, a Cachoeira do Aruã localizada no rio Arapiuns, distante a aproximadamente 10 horas por via fluvial, a partir de Santarém. Do patrimônio natural, fazem parte ainda igarapés, florestas, lagos, rios, serras e morros, ilhas, bosques, dentre outros.

Se por um lado o Patrimônio Natural já é explorado e conhecido internacionalmente, por outro, o Patrimônio Cultural da cidade ainda é quase desconhecido, sendo pouco valorizado e divulgado local, regional, nacional e internacionalmente. Talvez, essa falta de informação/conhecimento acerca da história de Santarém seja um dos fatores pelos quais vem se perdendo, há anos, parte de seus Patrimônios Edificados, como os relatados anteriormente.

\footnotetext{
11 Afirmação extraída da página oficial do Governo do Estado do Pará. Disponível em: http://www.paraturismo.pa.gov.br
} 
O chamado "Patrimônio de Pedra e Cal" precisa ser entendido pelo nativo/morador de Santarém como parte de sua história e memória. Essa informação não pode ficar somente na universidade, na escola ou com aqueles oficialmente ligados à cultura. $O$ poder público tem um papel fundamental nesse processo. Afinal, cabe a ele delegar ações, leis, decretos para a salvaguarda dos Bens Patrimoniais. Por outro lado, a comunidade também tem importante papel de exigir, fiscalizar e zelar por seu Patrimônio.

O Patrimônio Público Edificado, em sua essência, deveria ser de todos. Logo, cabe à comunidade o zelo e salvaguarda juntamente com as autoridades competentes, afinal, como postula Goodey (2002, p. 45), "quem tem o conhecimento mais enraizado, profundo e rico sobre um lugar? São aquelas pessoas que lá cresceram, ou aquelas que lá se estabeleceram como moradores e/ou profissionais". Para Funari e Pelegrini (2009, p. 35), "a preservação dos espaços de sociabilidade e do patrimônio material e imaterial contribui para aflorar afetos que estimulam o sentido de pertencimento da comunidade".

Em 1832, o escritor Vitor Hugo escreveu um artigo intitulado Guerre aux demolisseurs, no qual já manifestava sua preocupação com Patrimônio Histórico. Segundo ele, "a destruição de um prédio histórico e monumental não deve ser permitida a nenhum proprietário [...] há duas coisas num edifício: seu uso e sua beleza. Seu uso pertence ao proprietário, mas a beleza é de todos" (HUGO apud FONSECA, 1997 p. 29)

Quando um Patrimônio Edificado como Padaria Lucy é demolido vai-se junto uma parte da história e memória da cidade, das pessoas, o que foi muito bem colocado por um dos seguidores do "Blog do Jeso", ao afirmar que: "ver essas fotos da antiga padaria Lucy neste estado lamentável foi com ver parte da minha infância quebrada" (Marcelo).

Sobre a preservação e conservação dos Patrimônios Históricos, Oliveira (2008, p. 26) ressalta que:

Os chamados patrimônios históricos e artísticos têm, nas modernas sociedades ocidentais, a função de representar simbolicamente a identidade e a memória de uma nação. O pertencimento a uma comunidade nacional é produzido a partir da ideia de propriedade sobre um conjunto de bens: relíquias, monumentos, cidades históricas, entre outros. Daí o termo patrimônio. 
Conforme a Declaração do México na Conferência Mundial sobre as Políticas Culturais, o Patrimônio Cultural, em seu artigo 23, é assim definido:

Compreende as obras de seus artistas, arquitetos, músicos, escritores e sábios, assim como as criações anônimas surgidas da alma popular e o conjunto de valores que dão sentido à vida. Ou seja, as obras materiais e não materiais que expressam a criatividade desse povo: a língua, os ritos, as crenças, os lugares e monumentos históricos, a cultura, as obras de arte e os arquivos e bibliotecas (CURY, 2004 p. 275).

Nossa legislação máxima - Constituição Federal de 1988 - reservou dois artigos (215 e 216) para tratar da questão Cultural/Patrimonial, vejamos seus principais pontos:

Art. 215 O Estado garantirá a todos o pleno exercício dos direitos culturais e acesso às fontes da cultura nacional, e apoiará e incentivará a valorização e difusão das manifestações culturais.

Art. 216 Constituem patrimônio cultural brasileiro os bens de natureza material e imaterial, tomados individualmente ou em conjunto, portadores de referência à identidade, à ação, à memória dos diferentes grupos formadores da sociedade brasileira, nos quais se incluem: I as formas de expressão; II os modos de criar, fazer e viver; III as criações científicas, artísticas e tecnológicas; IV as obras, objetos, documentos, edificações e demais espaços destinados às manifestações artístico-culturais; $V$ os conjuntos urbanos e sítios de valor histórico, paisagístico, artístico, arqueológico, paleontológico, ecológico e científico.

$\S 1^{\circ} \mathrm{O}$ poder público, com a colaboração da comunidade, promoverá e protegerá o patrimônio cultural brasileiro, por meio de inventários, registros, vigilância, tombamento e desapropriação, e de outras formas de acautelamento e preservação.

$\S 2^{\circ}$ Cabem à administração pública, na forma da lei, a gestão da documentação governamental e as providências para franquear sua consulta a quantos dela necessitem.

$\S 3^{\circ} \mathrm{A}$ lei estabelecerá incentivos para a produção e o conhecimento de bens e valores culturais.

$\S 4^{\circ}$ Os danos e ameaças ao patrimônio cultural serão punidos, na forma da lei.

$\S 5^{\circ}$ Ficam tombados todos os documentos e os sítios detentores de reminiscências históricas dos antigos quilombos.

O Patrimônio Histórico Cultural de Santarém precisa ser tratado com a importância que tem, tanto pelos nativos, como pelos visitantes e turistas, juntamente com o poder público, afinal é a história, cultura e identidade de um povo que se ressignificam a mais de 350 anos, com características distintas, formadas a partir de sua descendência portuguesa, indígena e negra.

A cultura em Santarém é rica e diversificada. São exemplos representativos da colonização portuguesa, os edifícios localizados por todo o Centro Histórico e entorno, conforme já mencionados anteriormente; Patrimônios 
Edificados em localização mais afastada, tais como: a Igreja de Nossa Senhora da Saúde, no Distrito de Alter do Chão; o Colégio São José, situado na BR 163, km 19; a Fazenda Taperinha, situada a 80 km à leste de Santarém, via fluvial; Igreja na Vila de Arapixuna, distante a aproximadamente 40 minutos de Santarém, via fluvial.

Figura 24 - Igreja de Nossa Senhora da Saúde - Alter do Chão

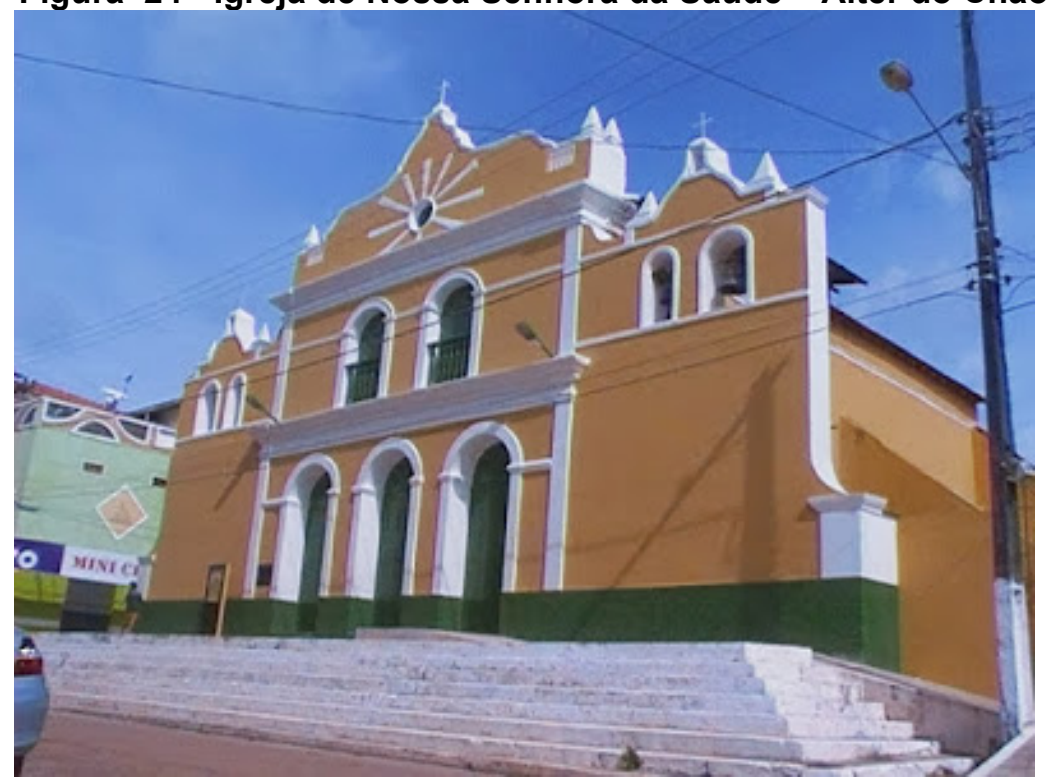

Fonte: http://macedoelivaldo.blogspot.com.br

Figura 25- Colégio São José

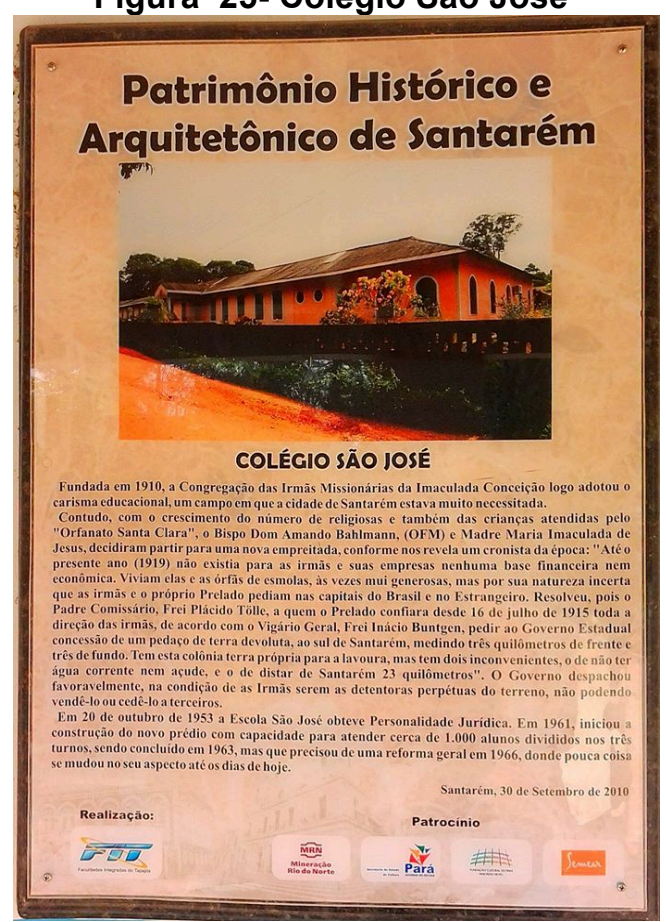

Fonte: https://www.facebook.com/pages/Escola-São-José 
Figura 26 - Fazenda Taperinha

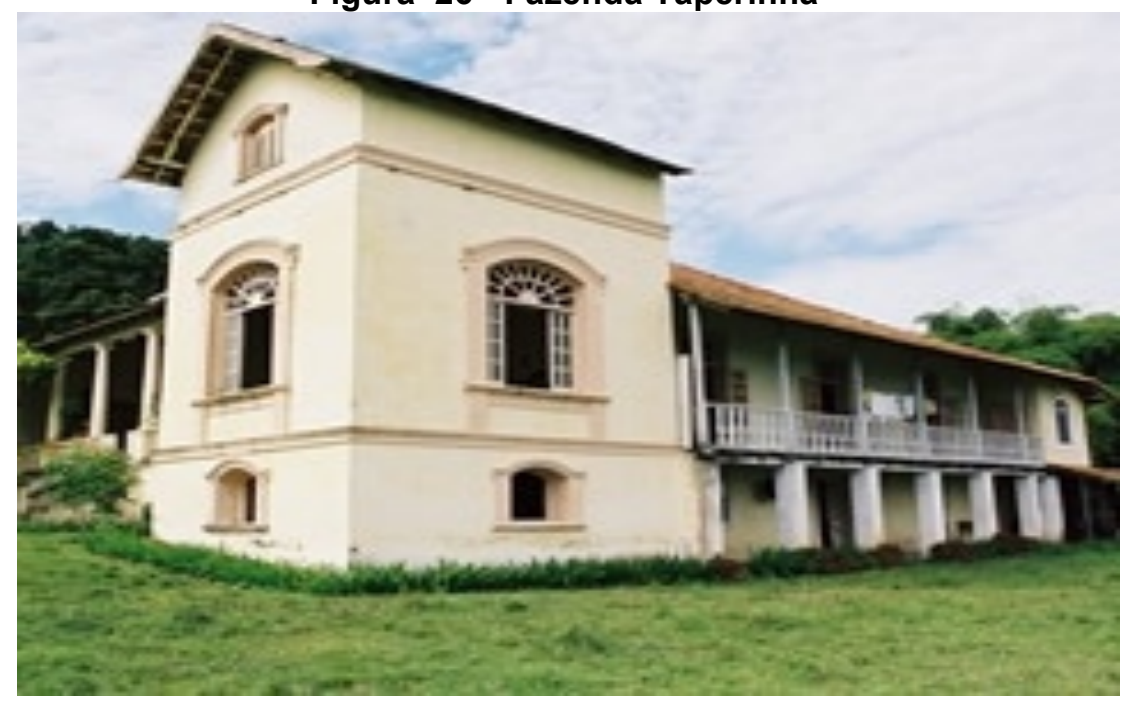

Fonte: http://historiacsd.blogspot.com.br

Figura 27- Igreja de Sant ana na Vila de Arapixuna

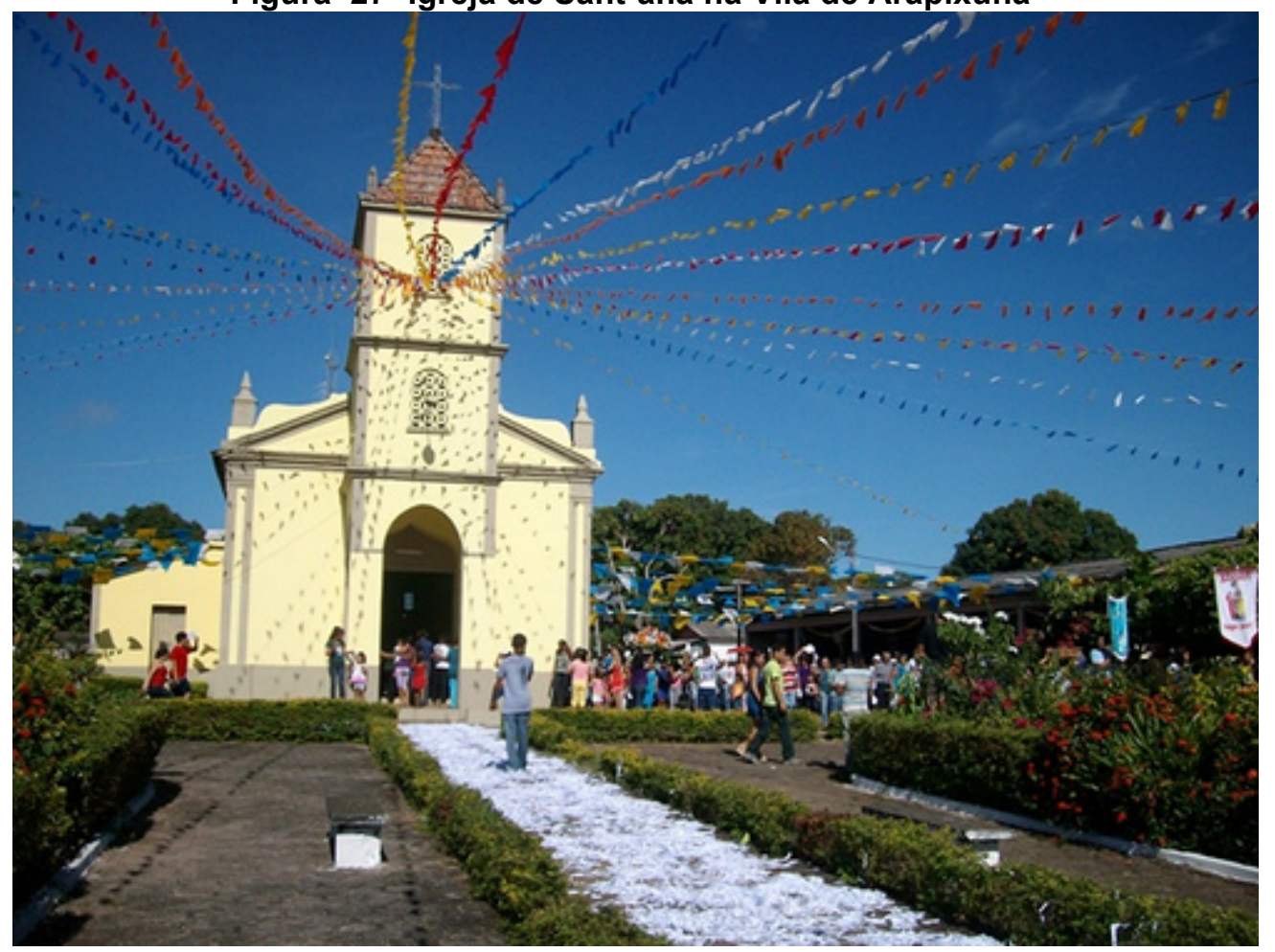

Fonte: http://www.jesocarneiro.com.br

Além de toda essa herança edificada, os portugueses trouxeram, para essa região, os costumes, a religiosidade e hábitos alimentares que se constituem em "Patrimônio Imaterial ou Intangível".

Segundo Gonçalves (2009, p. 28), fazem parte da categoria de Patrimônio Imaterial ou Intangível os "lugares, festas, religiões, formas de medicina popular, 
música, dança, culinária, técnicas". Para o referido autor, o mais importante está no aspecto valorativo e diferente do Patrimônio de Pedra e Cal que tem o tombamento como medida cautelar de proteção oficializada pelo Estado. Para tal categoria, o registro e o acompanhamento dessas práticas e representações são medidas indicadas. Sant'anna (2009) concorda com o mesmo pensamento ao afirmar que os Bens Culturais de natureza imaterial são dotados de uma dinâmica de desenvolvimento e transformação que não cabem nos conceitos de permanência e autenticidade. Para ela, registro e documentação apropriados em detrimento de intervenção, restauração e conservação.

Funari e Pelegrini (2006) contribuem para o debate ao afirmarem que a maneira de se fazer nhoques, a maneira como sambamos, os provérbios e ditos populares constituem-se também como Patrimônio Imaterial.

Os Bens de natureza imaterial estão amparados pelo decreto 3.551/2000 que estabelece uma política pública de identificação, inventariação e valorização desse Patrimônio, a saber: Livro de Registro dos Saberes (para registro de conhecimentos e modos de fazer), Livro das Celebrações (para as festas, rituais e os folguedos), Livro das Formas de Expressão (para a inscrição de manifestações literárias, musicais, plásticas, cênicas e lúdicas) e o Livro dos Lugares (destinado à inscrição de espaços onde concentram-se e reproduzem-se práticas culturais coletivas) (SANT'ANNA, 2009).

No artigo Para além da pedra e cal: por uma concepção ampla de patrimônio cultural, Maria Cecília Londres Fonseca cita como exemplo de Patrimônio Imaterial a arte dos repentistas e diz que, embora a presença física dos artistas e seus instrumentos musicais seja imprescindível para a realização do repente, a capacidade de improviso, as técnicas de composição dos versos, a agilidade dos interlocutores em responder à fala anterior é o que garante, a cada 'performance', sua originalidade. Dessa forma, se não for por algum meio de registro audiovisual, não tem como se perpetuar esse momento (FONSECA, 2009).

Recentemente (setembro de 2014), o Carimbó ${ }^{12}$, dança muito comum no estado do Pará, foi considerado como Patrimônio Cultural Imaterial do Brasil pelo IPHAN, fato que gerou muita alegria ao povo do Pará.

\footnotetext{
${ }^{12}$ O Carimbó é um ritmo paraense famoso pela batida do tambor chamado "curimbó". A manifestação cultural envolve passos característicos de casais de dançarinos, que usam um figurino que chama
} 
As lendas, rituais, festas, danças, artesanatos, culinária e boa parte dos hábitos alimentares são heranças dos índios que por aqui viveram em épocas passadas; já os negros trouxeram os rituais africanos, as danças, crenças, etc.

Tudo isso são exemplos da cultura imaterial da cidade, representada também pela música, poesia, escultura, pintura, dentre outros.

Por ser um Estado de dimensões continentais, o Pará tem, em seus municípios, diferentes sotaques e expressões muito peculiares. Dentre as palavras que constituem a cultura linguística no Pará, uma delas é única e, por isso, torna-se um grande diferencial entre os paraenses: "ÉGUA".

"Égua", que para as outras pessoas é o feminino de cavalo, para o paraense é uma espécie de vírgula em seu vocabulário e, dependendo do contexto, adquire a função de interjeição. Serve para várias situações como, por exemplo: um sentimento de espanto, admiração, rejeição, alívio, descontentamento, entre outros. Essa palavra é uma espécie de "marca registrada" dos paraenses. Se alguém "soltar" um égua perto de você, saiba que estará na presença de um paraense nato.

Em Santarém, existem algumas particularidades culturais que só se encontram por lá, dentre eles destaque-se: Piracuí (farinha de peixe, principalmente o Acari); Avium (minúscula espécie de camarão encontrado em grande quantidade na cidade da qual se fazem salgados diversos, tortas salgadas, patês, etc); Piracaia (herança indígena que consiste em fazer um pequeno buraco na areia da praia, a fim de que sejam assados os peixes na brasa que foram pescados na hora, de preferência em noite de luar).

Todos esses elementos enriquecem a cultura local que está em constante processo de mudança e fazem parte do patrimônio imaterial ou intangível da cidade.

Cultura é um termo complexo e está em constante processo de transformação, significação e ressignificação. Ela, "assim como a linguagem, mantêm sua distinção - sua 'identidade' -, mas ela nunca é a 'mesma' por muito tempo, ela permanece pela mudança" (BAUMAN, 2012, p. 43). Este autor 
sustenta que "a cultura é o inimigo natural da alienação [...], que ela é singularmente humana no sentido de que só o homem, entre todas as criaturas vivas, é capaz de desafiar sua realidade e reivindicar um significado mais profundo, a justiça, a liberdade e o bem, individual ou coletivo" (BAUMAN, 2012 pp. 301-302).

A cultura de Santarém é muito marcante, o que pode ser observado nas lendas como a do boto (cetáceo parecido com o golfinho), que vira homem e engravida as moças às margens dos rios, em noites de lua cheia; ou a lenda da cobra grande que se faz presente no imaginário dos povos dessa região; através da música muito bem representada pelo violonista Sebastião Tapajós, conhecido nacional e internacionalmente, pela cantora e compositora Maria Lídia, pelo imortal maestro Wilson Fonseca, carinhosamente conhecido como maestro Isoca; pela Festa do Sairé, uma das maiores manifestações culturais da região; pela rica diversidade de peixes de água doce; pelo artesanato das cuias pintadas; pelos traçados em palha do Rio Arapiuns; pelos artistas plásticos como Laurimar Leal, Elias do Rosário e mestre Isauro, dentre tantos outros.

O antropólogo Clifford Geertz afirma: "O conceito de cultura que eu defendo [...] é essencialmente semiótico. Alicerçado em Max Weber que sustenta que o homem é um animal amarrado a teias de significados que ele mesmo teceu, assumo a cultura como sendo essas teias e a sua análise" (Geertz, 1989, p.4).

Para Martins (2003, pp. 44-45),

O conceito de cultura complementa o de sociedade [...], pois a cultura representa as ideias, os conceitos e os valores que regulam coletivamente e individualmente tais relações, transmitidos no processo de socialização, por sua vez criados pela transformação ou invenção, cuja qualidade mais significativa é de ser basicamente homogênea.

Acerca da cultura popular, Alfredo Bosi (1987, p. 44) infere que se ela for realmente emanada do povo nunca morrerá, afinal enquanto ele existir (o povo), ela estará viva. "Cultura popular é a cultura que o povo faz no seu cotidiano e nas condições em que ele a pode fazer". Nessa perspectiva, a Festa do Sairé é uma manifestação eminentemente de cultura popular, pois sempre foi sustentada pelo povo, pelos antigos moradores da Vila de Alter do Chão. Tal festa já passou por 
tantas ressignificações, mas continua viva, em nossa contemporaneidade, atraindo mais turistas para a região.

A Festa do Sairé (SANTIAGO, 1996) existe a mais de 300 anos na Vila Balneária de Alter do Chão, localizada a aproximadamente $35 \mathrm{~km}$ do centro de Santarém. Trata-se de uma mistura de elementos religiosos e profanos. Tem início sempre na segunda semana de setembro e vai de quinta a segunda (cinco dias corridos). A festa inicia com a busca dos mastros, que consiste em retirá-los da floresta para posteriormente fincá-los na "Praça do Sairé", sendo que um é de responsabilidade dos homens, e o outro das mulheres. Em seguida, são enfeitados com frutas e outros objetos (simbolizando fartura). No último dia da festa, há a disputa entre homens e mulheres para ver quem derruba primeiro os mastros.

Conforme estudos sobre a festa do Sairé, uma corrente de pesquisadores afirma que ela teve origem quando os índios Boraris começaram a receber os colonizadores. Como sinal de reverência a estes, confeccionaram o semi-arco com fitas coloridas e algodão que simbolizam a fartura. Entretanto, outros estudiosos afirmam que o símbolo do Sairé tem origem com a catequese dos jesuítas, e o semi-arco enfeitado de fitas e algodão, juntamente com as três cruzes, representam a Santíssima Trindade.

Em 1997, a festa passou por mudanças profundas: o nome Sairé passou a ser grafado Çairé. A festa, que então ocorria no mês de julho, passou a acontecer no mês de setembro, e o que mais "mexeu" na estrutura da festa foi, sem dúvida, a inserção da disputa dos Botos Cor de Rosa e Tucuxi. Essas transformações, ocorridas a partir de 1997, só reforçam a ideia de que as tradições não são estáticas, ou seja, são históricas e, portanto, sujeitas a transformações e ressignificações. Nesse sentido, a Festa de Sairé, como qualquer outro tipo de manifestação cultural é, ao longo do tempo, tessida e retessida dentro dessa teia de significados que denominamos cultura.

Outro conceito de cultura que se buscou, sustenta que "cultura é um conjunto interligado de regras e parâmetros compartilhados por uma sociedade que produz o comportamento considerado aceitável por esta" (BURNS, 2002, p. 77).

Para Claval: 


\begin{abstract}
'A cultura constitui-se de tudo que os homens adquirem no transcurso de sua vida'. Recebemos um emaranhado significativo de comportamentos, de saber-fazer, de conhecimentos e crenças de nossos pais e das pessoas com as quais convivemos jovens: a cultura constitui-se por meio de objetos e ritos do passado, é um patrimônio; é a experiência individual e coletiva, a maneira como reagimos aos eventos cotidianos, o que também integra o presente; a cultura consolida-se e se movimenta nos planos que os grupos sociais imaginam para o futuro. A cultura deve ser lida como uma noção dinâmica, que interliga o passado, o presente e o futuro" (COSTA, 2012, p.106).
\end{abstract}

Já Bauman (2012, pp. 26-27) infere que "falamos de cultura sempre que a vida produz certas formas pelas quais se expressa e se realiza, obras de arte, religiões, ciências, tecnologia, leis e uma infinidade de outras". Para Denys Cuche (2002), o homem é, em sua essência, um ser de cultura, ou seja, a cultura é própria dele.

Brusadim (2012, p. 35-36), parafraseando Roger Chartier, destaca que o conceito de cultura:

Denota um padrão, transmitindo historicamente, de significados corporizados em símbolos, um sistema de concepções herdadas, expressas em formas simbólicas, por meio das quais os homens se comunicam, perpetuam e desenvolvem seu conhecimento e atitudes perante a vida.

A ideia de cultura defendida por Chartier está em consonância com a definição de cultura postulada por Lévi-Straus (1950, p. 19), ao afirmar que "toda cultura pode ser considerada como um conjunto de sistemas simbólicos". Nessa mesma linha de pensamento, Barretto (2007) sustenta a mesa ideia de Adam Kuper, ao enfatizar que, apesar de não haver um consenso universal acerca da definição de cultura, há convergências quanto ao tratamento que se dá a determinados sistemas simbólicos - ideias, valores, atitude mental coletiva -, visto que há variações de significados em cada grupo humano.

Além da Festa do Sairé - rica em simbolismos, imaginários, dança, tradição, cores, aromas, performances, religião -, existe também o Festival Folclórico do Colégio Dom Amando (um dos mais tradicionais da cidade); o Festival Borari na Vila Balneária de Alter do Chão, em julho; o Festival do Açaí na comunidade de Santa Luzia; o Festival do Charutinho (espécie de peixe muito apreciado nessa região que pode ser preparado de muitas maneiras, porém o mais tradicional é frito até ficar crocante), na comunidade de Ponta de Pedras; o Festival do Folclore, que ocorre todos os anos no mês de agosto em uma das 
principais praças da cidade - Barão de Santarém; o Festival da Cultura Popular; a Mostra de Teatro Amador de Santarém, etc.

A preocupação com o Patrimônio Natural, Material e Imaterial de Santarém sempre foi motivo de inquietações pelo pesquisador. Sabe-se que o Patrimônio Cultural é um somatório, um conjunto de bens inerentes ao conceito de cultura e, para efeito desta pesquisa, deu-se ênfase maior aos ditos de "Pedra e Cal", sem desmerecer o natural e imaterial ou intangível, mas por entender que os Patrimônios Edificados de Santarém necessitam urgentemente de políticas públicas que zelem por sua salvaguarda, juntamente com ações de informação e sensibilização da sociedade local.

Não se pode falar em cultura em Santarém ou de Santarém sem considerar seu Patrimônio rico em memória e identidade. E o Patrimônio Edificado faz parte desse acervo todo. O Centro Histórico constitui-se em "lugar de memória", história, identidade individual e coletiva. Sua preservação contribui para aflorar afetos e podem estimular o sentido de pertencimento da comunidade (FUNARI e PELEGRINI, 2009).

\subsection{Um tour pelo Centro Histórico de Santarém}

A partir de agora, procurar-se-á elencar os Patrimônios Edificados existentes no Centro Histórico de Santarém. Para atender aos objetivos desta pesquisa, dar-se-á maior evidência aos Patrimônios que os alunos da Escola Estadual de Ensino Fundamental e Médio Frei Ambrósio citaram durante as entrevistas: Igreja Matriz de Nossa Senhora da Conceição (padroeira dos santarenos), Centro Cultural João Fona e Museu Dica Frazão. Estes Patrimônios Edificados se sobressaíram no momento da entrevista, dessa forma, fazem parte das memórias dos alunos. Em algum momento, tais alunos já estiveram no interior desses prédios ou já passaram pela frente deles, notando sua presença como Patrimônio da cidade, como Patrimônio que pertence a eles.

\subsubsection{Igreja Matriz de Nossa Senhora da Conceição}


A Igreja Matriz de Nossa Senhora da Conceição (a padroeira dos santarenos) - Catedral de Santarém - teve sua primeira instalação no Largo do Pelourinho, onde hoje é a Praça Rodrigues dos Santos. Era uma pequena capelinha erguida pelo fundador da cidade, o jesuíta Padre João Felipe Bettendorff.

No ano de 1761, houve o início da construção da atual Catedral, mais a leste, sobre um antigo cemitério dos índios Tupaius. Conforme Fonseca (1996) e Santos (1999), a igreja anterior apresentava aspecto diferente da atual no que se refere às torres laterais, por serem mais baixas.

$\mathrm{Na}$ entrada principal da Igreja Matriz de Nossa Senhora da Conceição, encontra-se uma placa em metal onde o Bispo, à época (1992), Dom Lino Vombommel e o Vigário Padre Valdir Silveira fizeram um breve histórico da edificação. Há informações importantes como, por exemplo, o ano do início da construção da atual Matriz. Em 1851, a torre do lado esquerdo desabou e, meses depois, a torre do lado direito foi demolida, pois, segundo dois engenheiros civis franceses que estavam em trânsito pela cidade, ao fazerem uma perícia, diagnosticaram que "a parede lateral do templo estava desiquilibrada, sem condições, portanto, para suportar uma nova torre" (FONSECA, 1996 p. 35).

Entre 1876 e 1881, houve a restauração das paredes do templo e, em 1895 , ocorreu a reforma geral e colocação de vidros coloridos nas janelas laterais e frontispício (SANTOS, 1999 p. 283).

Em 1903, o templo foi denominado Catedral de Santarém e, entre 1930 e 1933, ocorreu a construção das torres atuais.

Como se observa, a atual Igreja Matriz já passou por várias intervenções tanto interna como externamente, conforme informações colhidas da placa de metal citada anteriormente. Da planta original só restam as paredes. Entretanto, apesar de todas essas modificações, o templo continua imponente e recebe muitos visitantes e turistas todos os dias. 
Figura 28 - Igreja Matriz de Nossa Senhora da Conceição

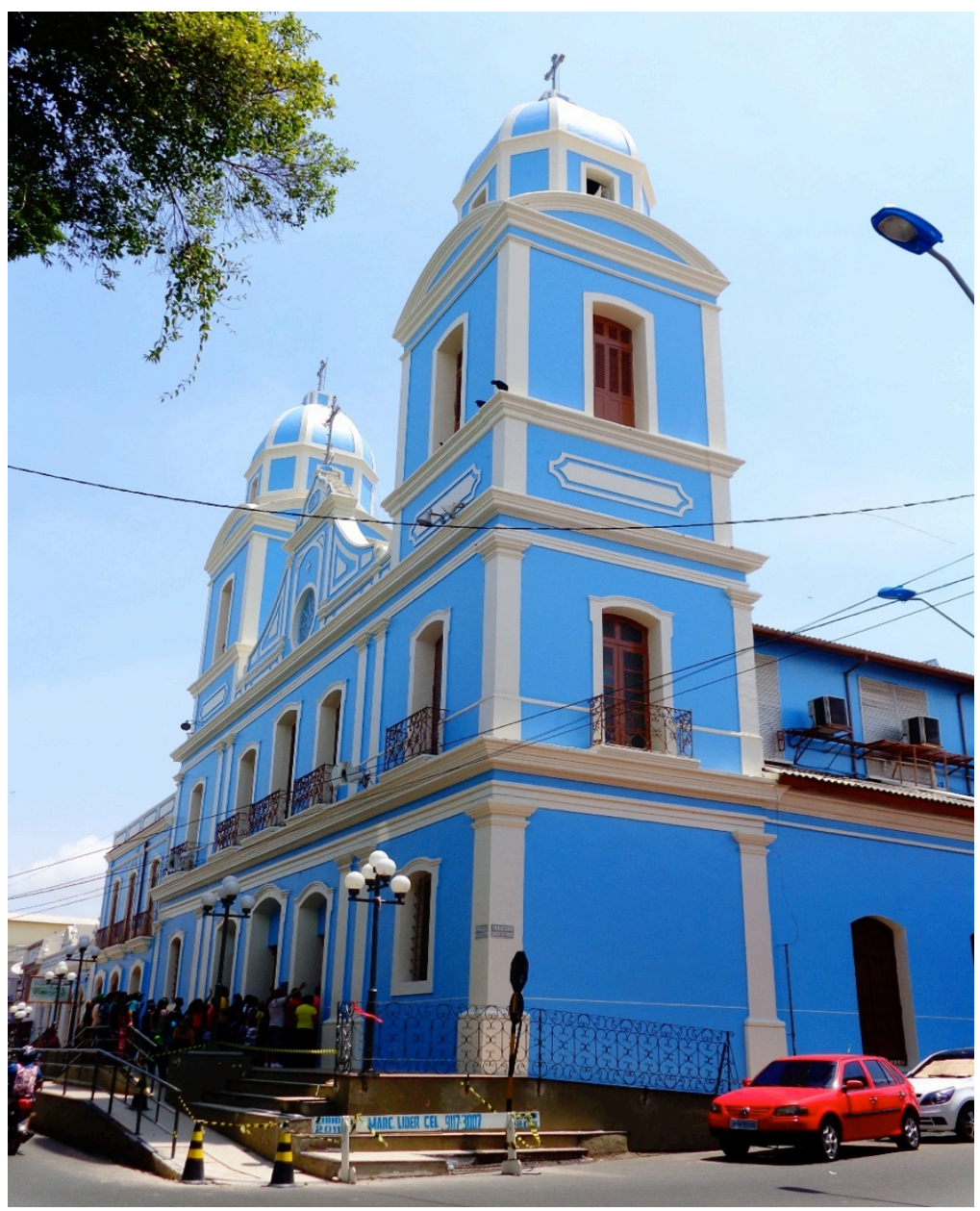

Fonte: Elias Mota

Figura 29- Antiga Igreja Matriz de Nossa Senhora da Conceição

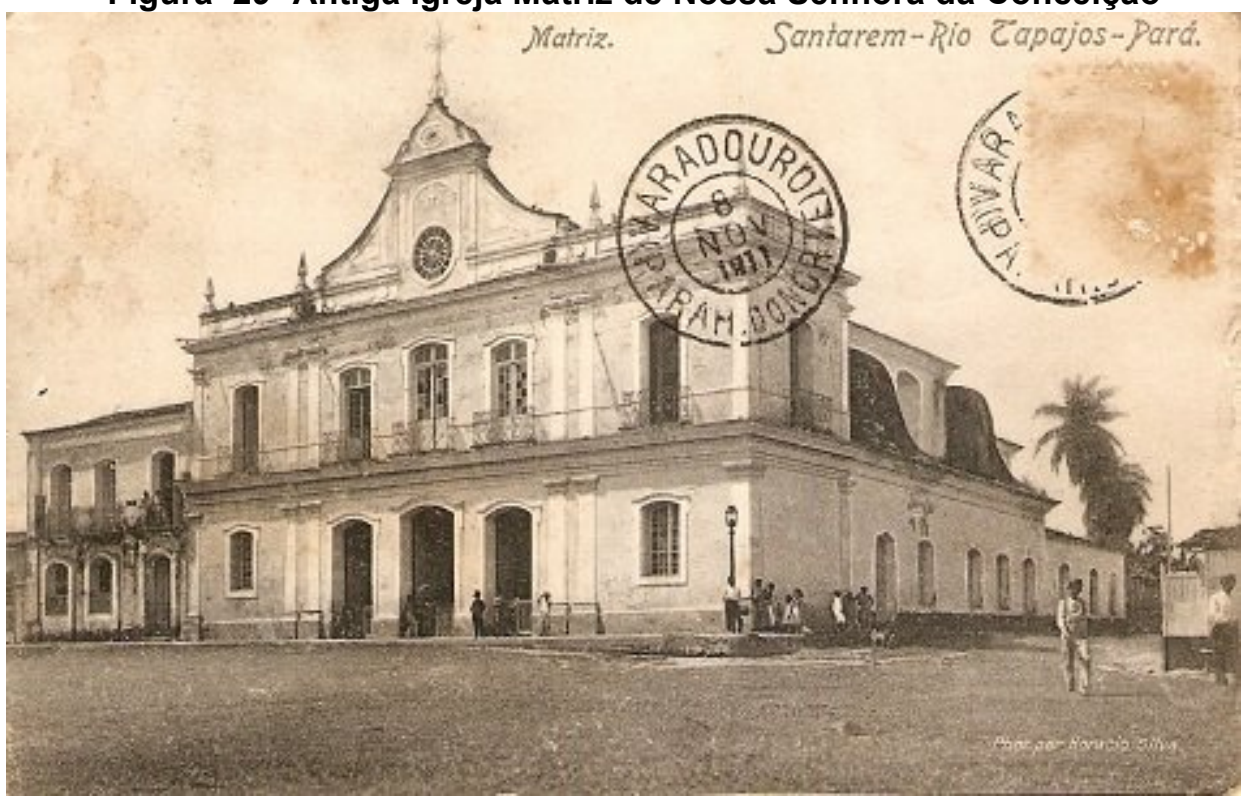

Fonte: http://www.ignacioneto.blogspot.com.br 
Em seu interior, encontra-se o Crucifixo Von Martius, feito de ferro fundido, com 1,62 metros de altura. Esse crucifixo foi doado pelo cientista alemão Karl Friedrich Von Martius, depois que este sofreu um naufrágio, quando navegava pelo rio Amazonas, próximo a Santarém. O objeto foi doado em agradecimento por ter sobrevivido.

O Cavalleiro Carlos Fred. Phil. de Martius, membro da Academia R. das Ciências de Munich, fazendo de 1817 a 1820 de ordem de Maximiliano José, Rei da Baviera, uma viagem scientifica pelo Brazil, e tendo sido aos 18 de setembro de 1819 salvo por misericórdia divina do furor das ondas do Amazonas, junto à Villa de Santarém, mandou, como monumento de sua pia gratidão ao todo poderoso, erigir este crucifixo nesta igreja de nossa Senhora da Conceição, no ano de 1846. (gravação, em relevo, na chapa de ferro do Crucifixo de Von Martius).

\section{Figura 30 - Crucifixo Von Martius}

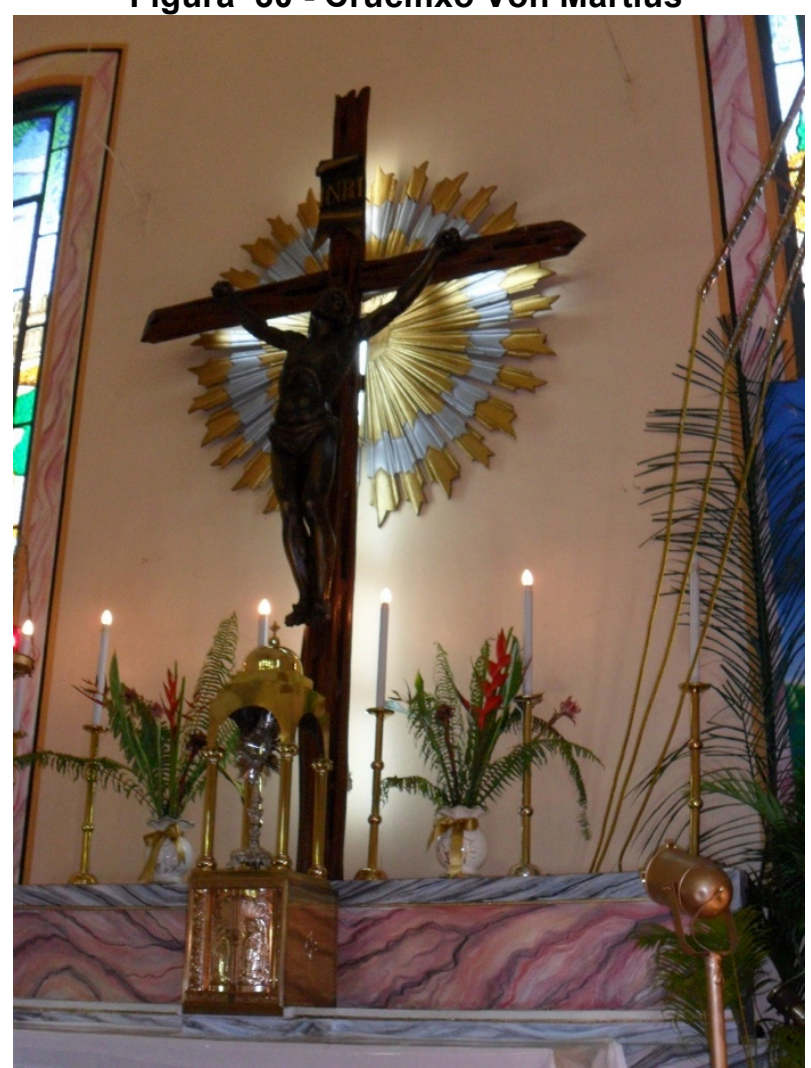

Fonte: Elias Mota

Ao lado da Igreja Matriz (anexo), encontra-se o Museu de História e Arte Sacra de Santarém que contempla, em seu interior, algumas imagens confeccionadas em madeira talhada - objetos usados em ocasiões especiais pelos primeiros religiosos que vieram para Santarém -, telas, livros e catálogos das festividades da Padroeira da cidade, Nossa Senhora da Conceição. 
Figura 31-Museu de Arte Sacra de Santarém

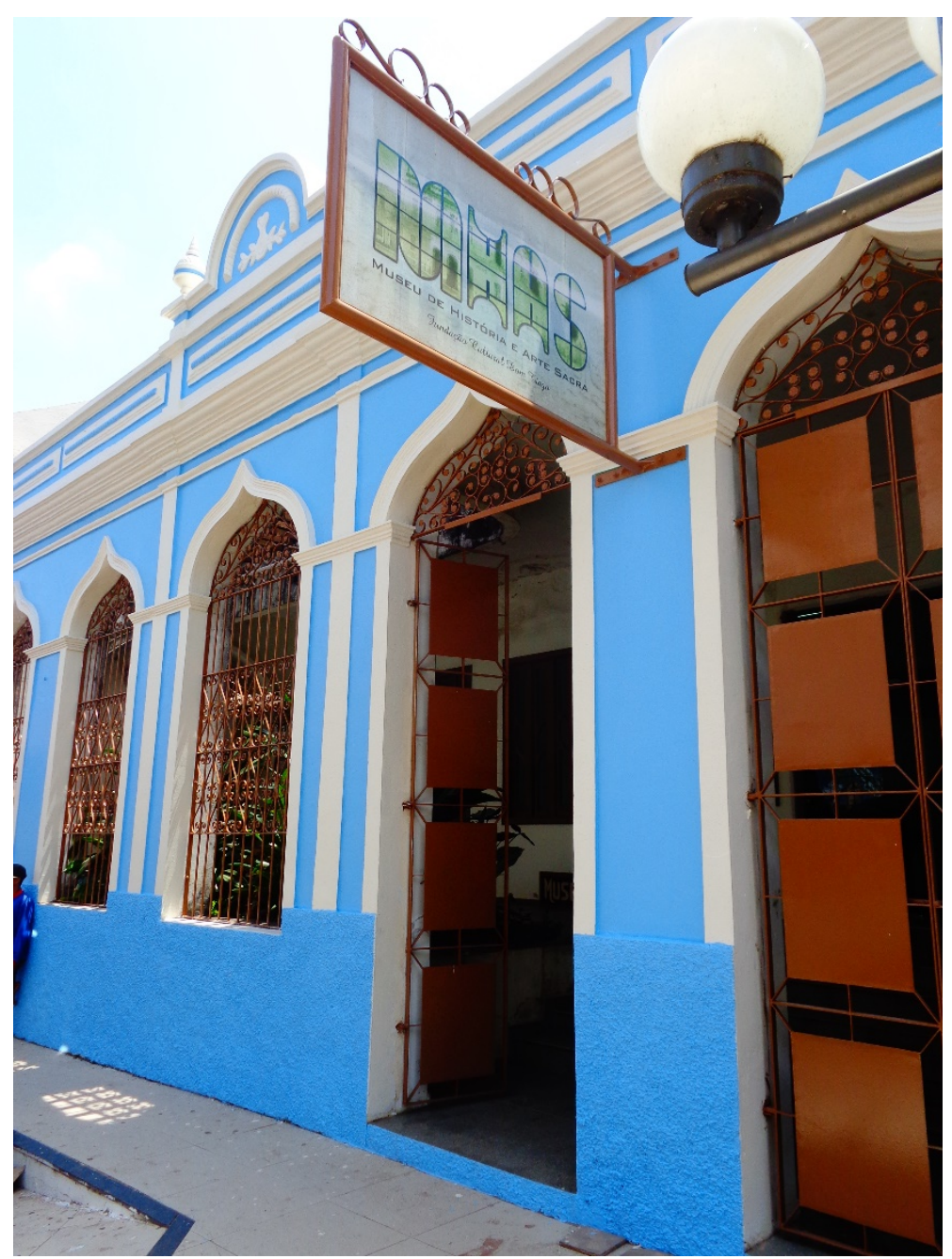

Fonte: Elias Mota

Em frente à igreja matriz estão localizados mais dois importantes exemplos de Patrimônio Edificado da cidade: a Garapeira Ypiranga e o Coreto da Praça Monsenhor José Gregório. A primeira é local de venda de caldo de cana, também conhecido pelos moradores de Santarém como "garapa", salgados diversos e, no passado, era ponto de encontro da sociedade local; já o coreto funcionou no passado como espaço para declamações de poesias, comunicados, apresentações de bandas de músicas regionais. Na atualidade, está sem uso específico. 


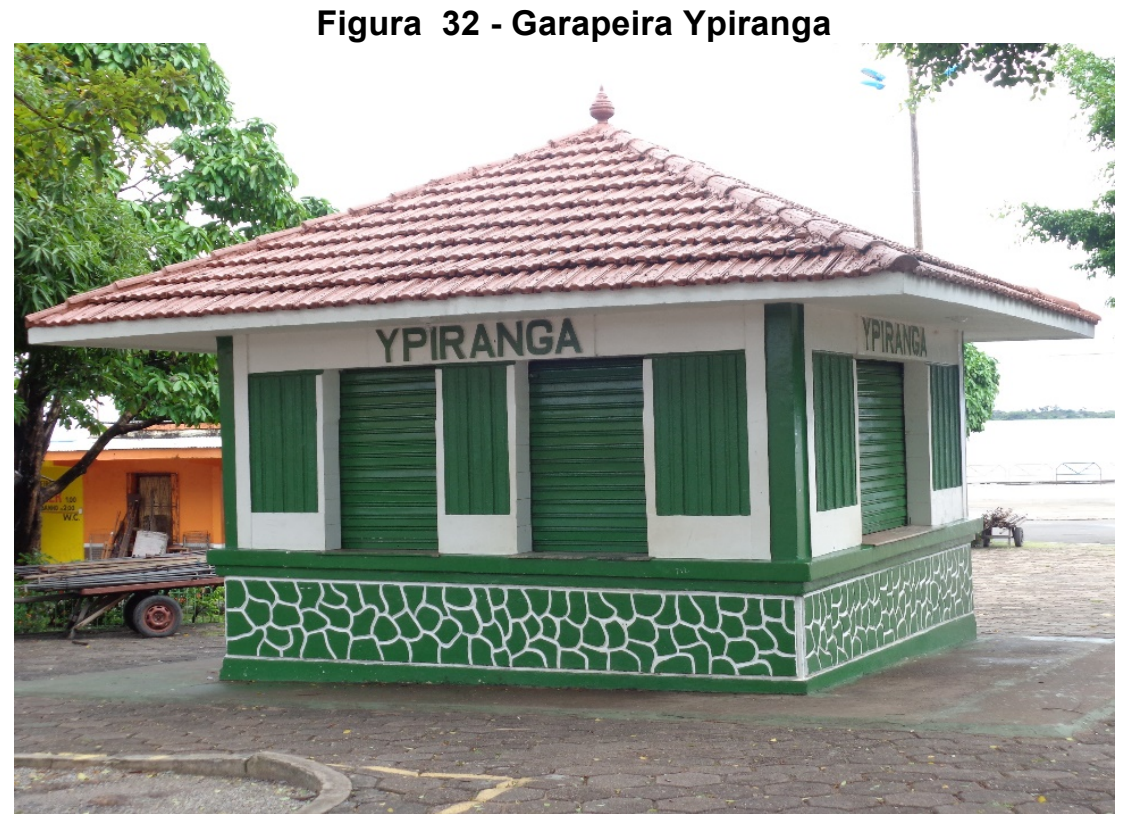

Fonte: Elias Mota

Figura 33 - Garapeira Ypiranga no passado

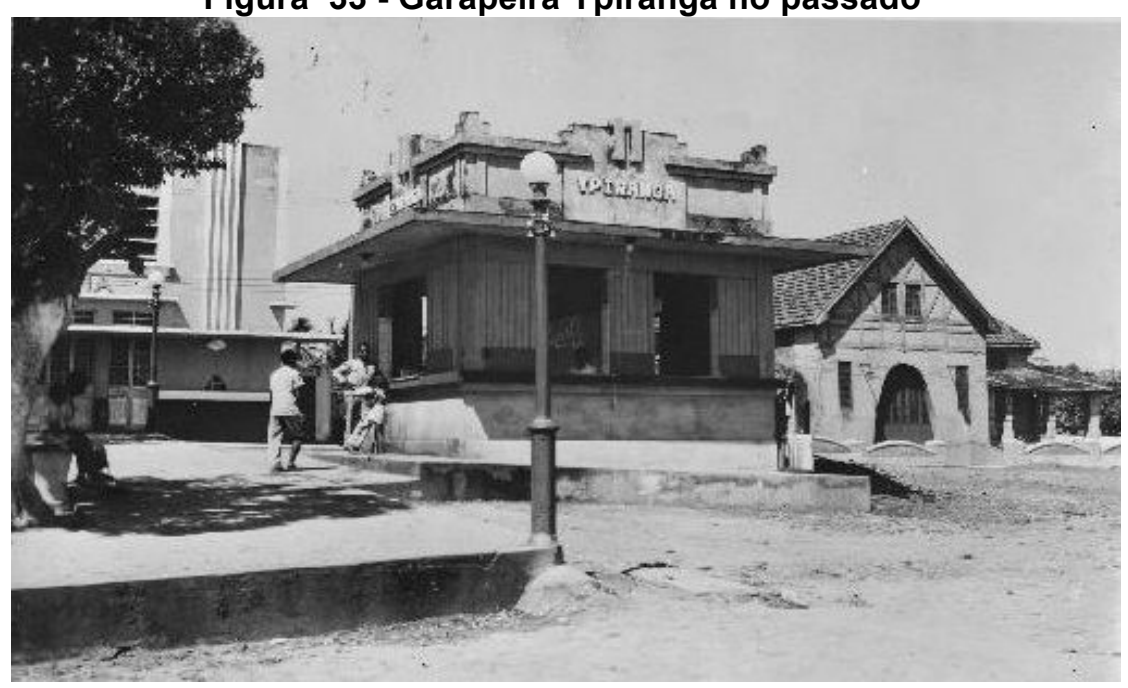

Fonte: Fonte: http://www.ignacioneto.blogspot.com.br 
Figura 34- Coreto da Praça Monsenhor José Gregório

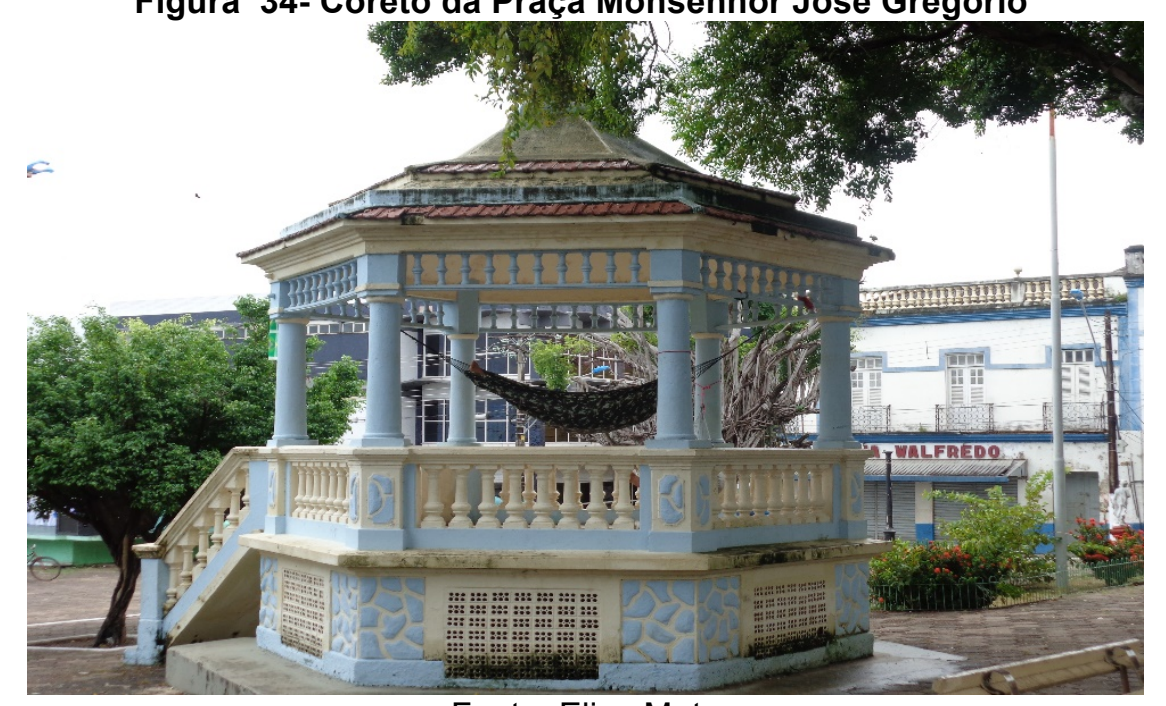

Fonte: Elias Mota

Em 2009, a Matriz teve sua área externa toda pintada e, em 2012, foram colocadas rampas para facilitar a acessibilidade de pessoas portadoras de necessidades especiais onde, antes, só havia escadas.

No ano de 2014, a Matriz passou novamente por pintura total na parte externa. Talvez, por ser cenário todos os anos do Círio de Nossa Senhora da Conceição, com saída da Igreja de São Sebastião e chegada à Matriz, esse Patrimônio Edificado é o mais bem cuidado da cidade, constituindo-se também como a edificação mais antiga de Santarém (FONSECA, 2007).

\subsubsection{Centro Cultural João Fona - Museu de Santarém}

Esse importante patrimônio edificado está localizado na Rua do Imperador, na Praça Barão de Santarém, em área nobre da cidade, de frente para o encontro das águas dos rios Amazonas e Tapajós. Sua construção teve início no ano de 1853, concluído em 1867 e oficialmente ocupado em 1868. É atribuída sua autoria ao major engenheiro Marcos Pereira Salles.

Tempos atrás, o prédio já funcionou como Fórum de Justiça de Santarém, Presídio, Intendência e Prefeitura Municipal e, hoje, é denominado Centro Cultural por haver, em seu interior, muito da história de Santarém como réplicas dos Vasos de Gargalo e Cariátides, móveis antigos, telas de artistas locais, 
fragmentos da Cerâmica Tapajônica e o esqueleto de uma baleia Minke, que encalhou em um banco de areia no Rio Tapajós, em 2007.

O atual diretor do Centro Cultural João Fona é o artista plástico (pintor, escultor e artesão) Laurimar Leal, um ícone da cultural em Santarém, com vasta obra na cidade, no país e internacionalmente. Sua marca registrada é a pintura a óleo, e no interior do Centro Cultural há uma exposição permanente de suas telas dos antigos prefeitos de Santarém.

O nome do Centro Cultural é uma homenagem a João Batista Pereira Fona, exímio pintor e hábil violonista autodidata que introduziu um dos traços mais marcantes da cultura em Santarém - a pintura em cuias. Essas pinturas, feitas de forma artesanal, até hoje são referências culturais na cidade, cuja beleza encanta turistas do mundo inteiro que por aqui passam.

João Fona faleceu em São Paulo, em 25 de fevereiro de 1964 (SEMTUR, 2013 p. 174).

Atualmente, o Centro Cultural está fechado para reforma.

Figura 35 - Centro Cultural João Fona - Museu de Santarém

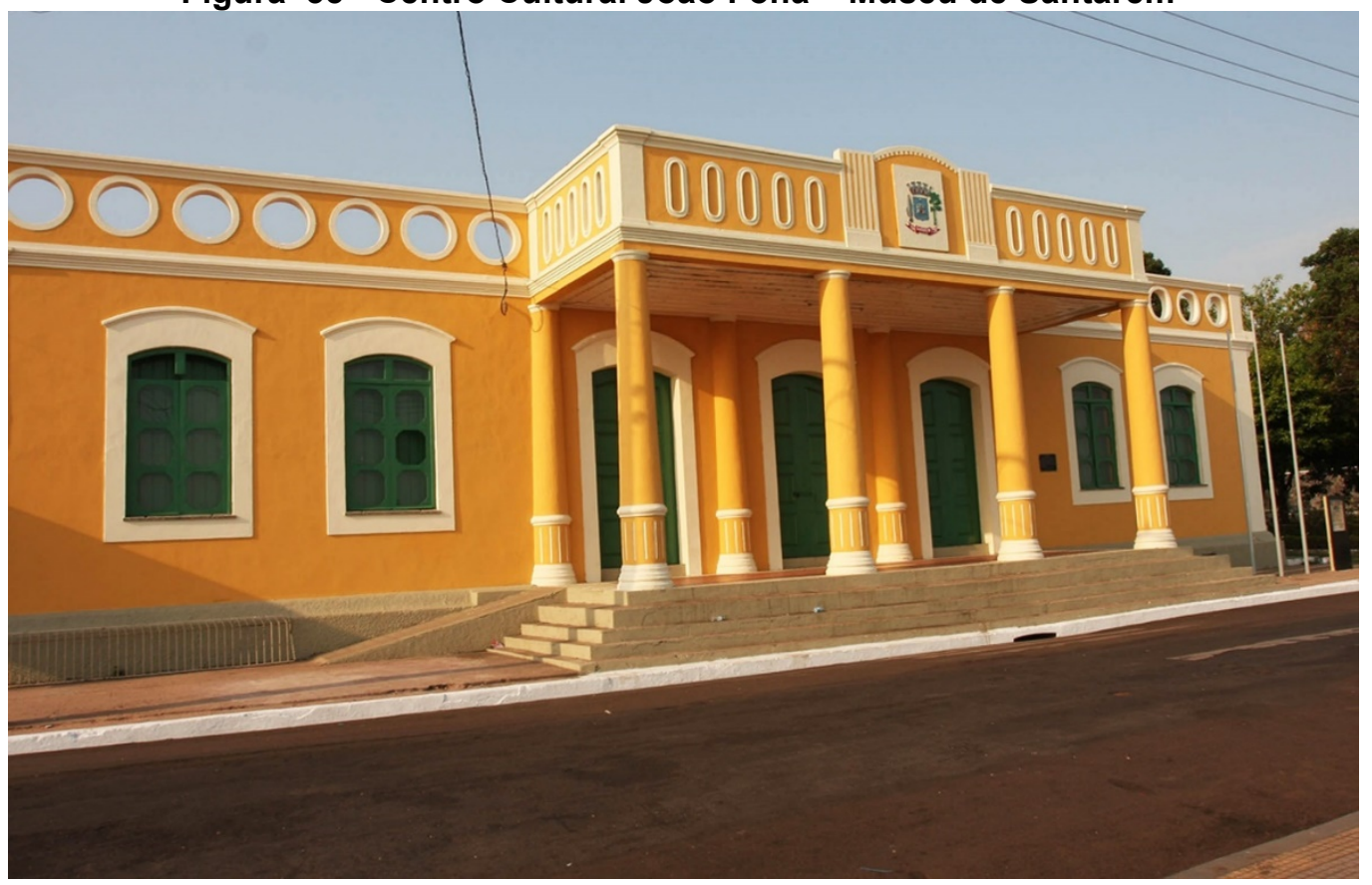

Fonte: http://saire.pa.gov.br 
Figura 36 - Interior do Centro Cultural João Fona - Museu de Santarém

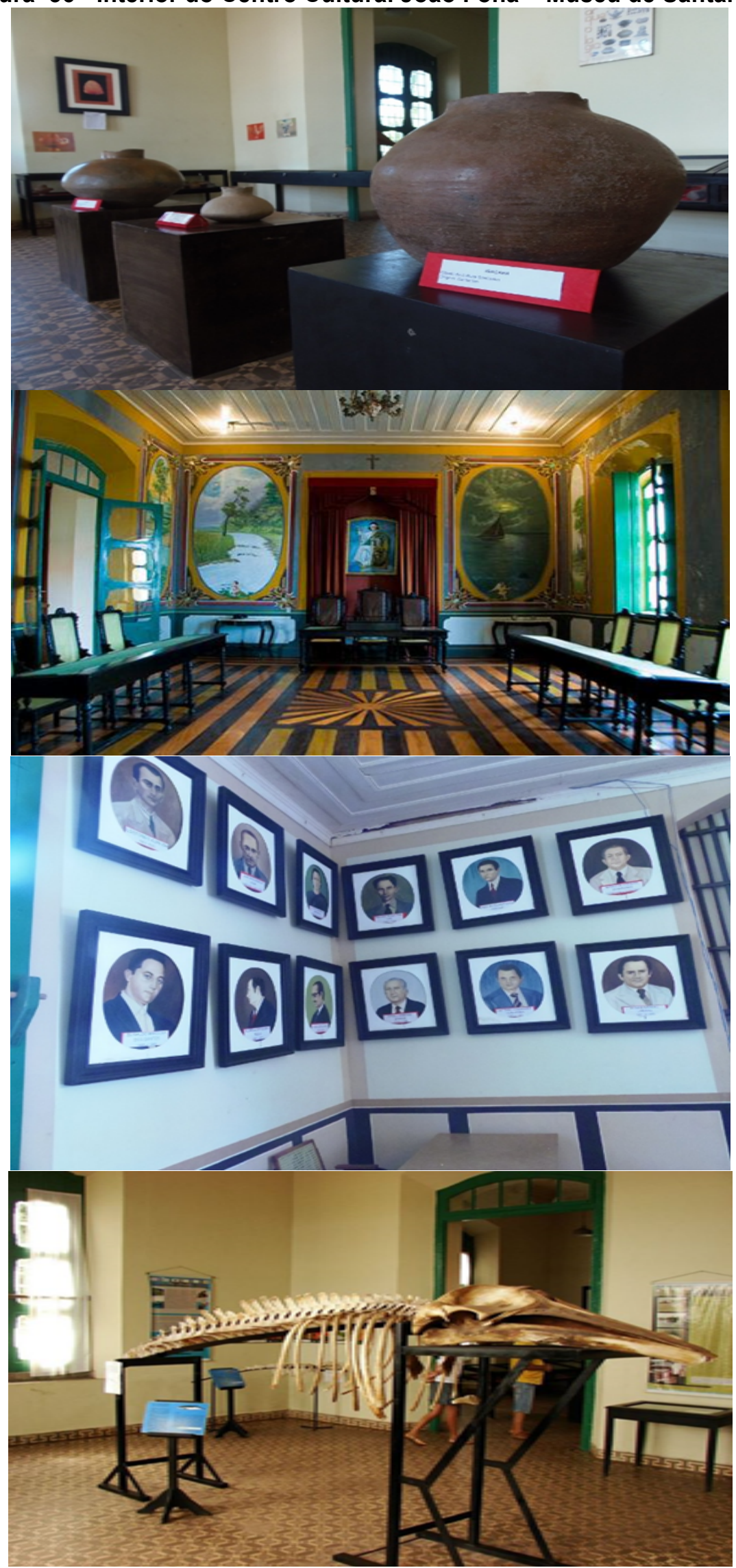

Fonte: http://saire.pa.gov.br 


\subsubsection{Museu Dica Frazão}

A senhora Raimunda Rodrigues Frazão, mais conhecida em Santarém como Dica Frazão, é a idealizadora do Museu que recebe seu nome. Nascida em Capanema/PA, em 29 de setembro de 1920, chegou em Santarém em 1943, de onde não saiu mais.

Exímia artesã, com sua matéria prima, retirada da floresta através dos índios (como ela fala), confecciona peças de vestuário como vestidos, saias e acessórios, a exemplo de bolsas e carteiras feitas de fibras naturais de malva e juta, raízes, palha de tucum, de buriti e açaizeiro, sementes de melancia, melão, jerimum e pepino, leques feitos de pena de ganso criados no quintal de sua residência.

Orgulha-se de ter criado peças para a Rainha Fabíola, da Bélgica, para o ex-presidente Jucelino Kubitschek e, também, para o Papa João Paulo II (SEMTUR, 2013).

O Museu funciona em sua casa, localizado à Rua Floriano Peixoto, 281 Centro. Foi inaugurado em 22 de junho de 1999. A referida artesã foi a primeira a utilizar raiz de patchuli no artesanato em Santarém.

Fazem parte do museu mais de 150 peças de artesanato, entre as quais, réplicas das vestimentas de figuras ilustres, como as citadas anteriormente.

Uma de suas características principais é a vivacidade e alegria de viver, contar suas histórias...conversar por horas. Dona Dica, assim como o artista plástico Laurimar Leal, são Patrimônio vivos da cidade de Santarém. 
Figura 37 - Museu Dica Frazão

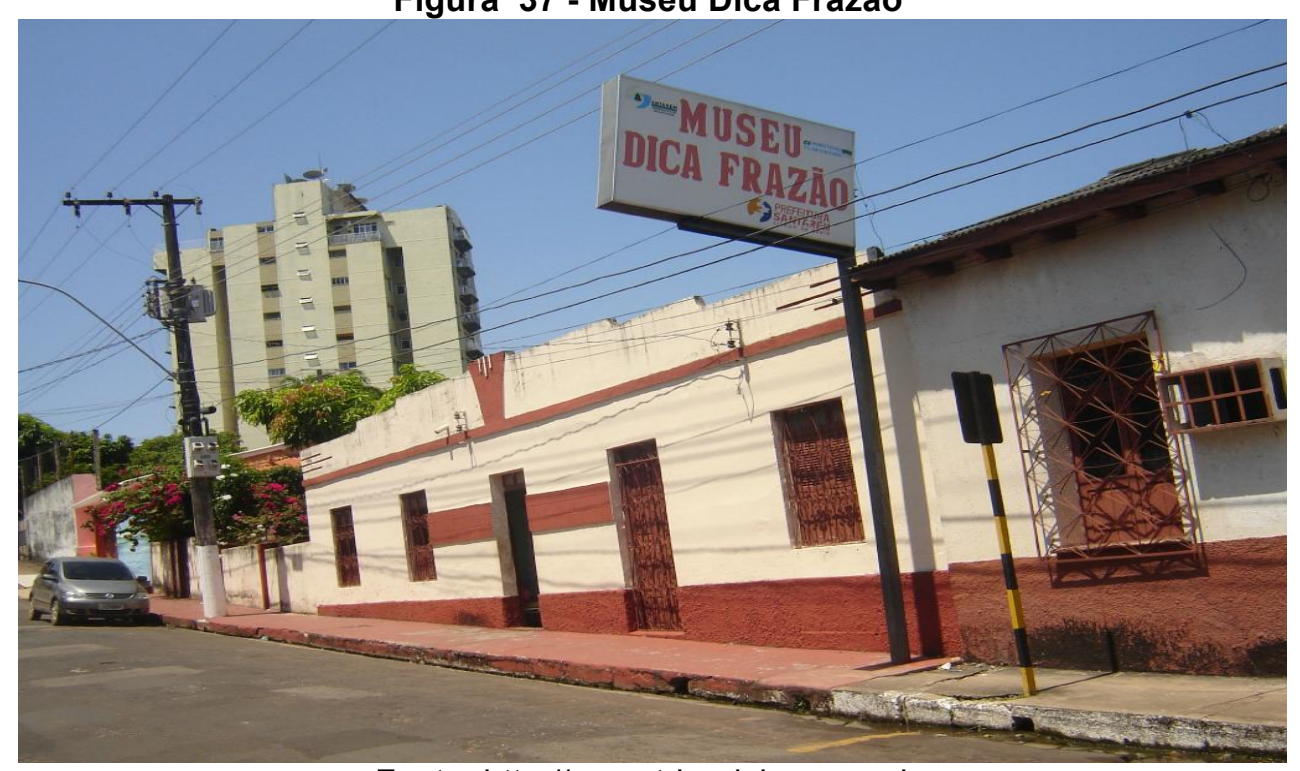

Fonte: http://www.tripadvisor.com.br

Figura 38 - Réplica da Vestimenta da Rainha Fabíola da Bélgica

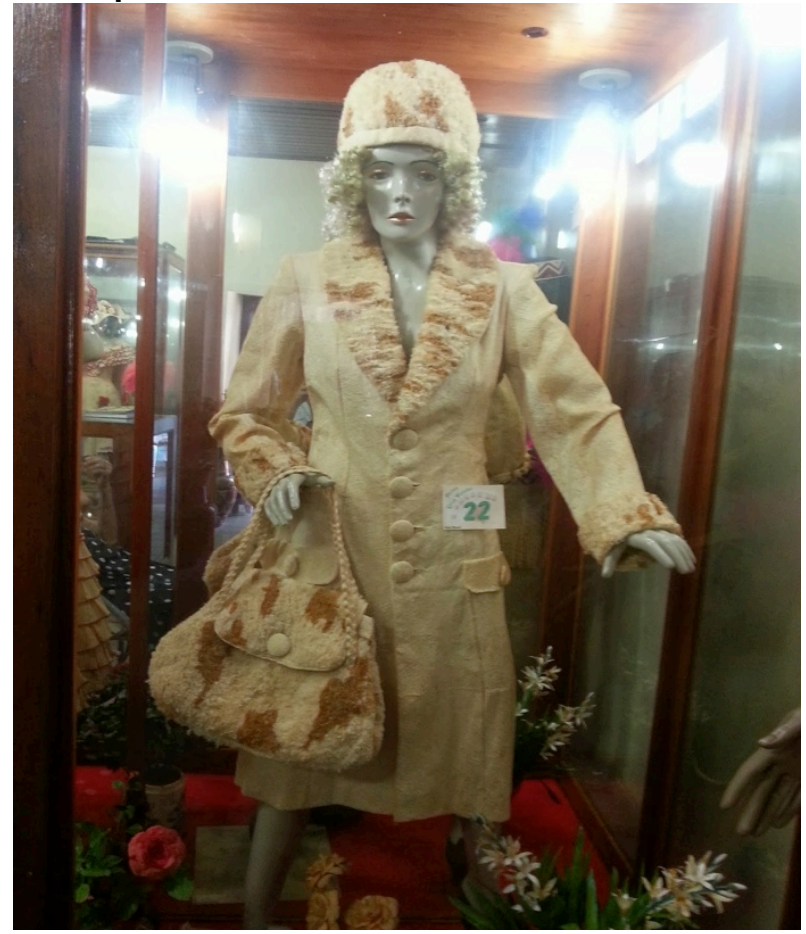

Fonte: http://mansardas.blogspot.com.br 
Figura 39 - Interior do Museu Dica Frazão

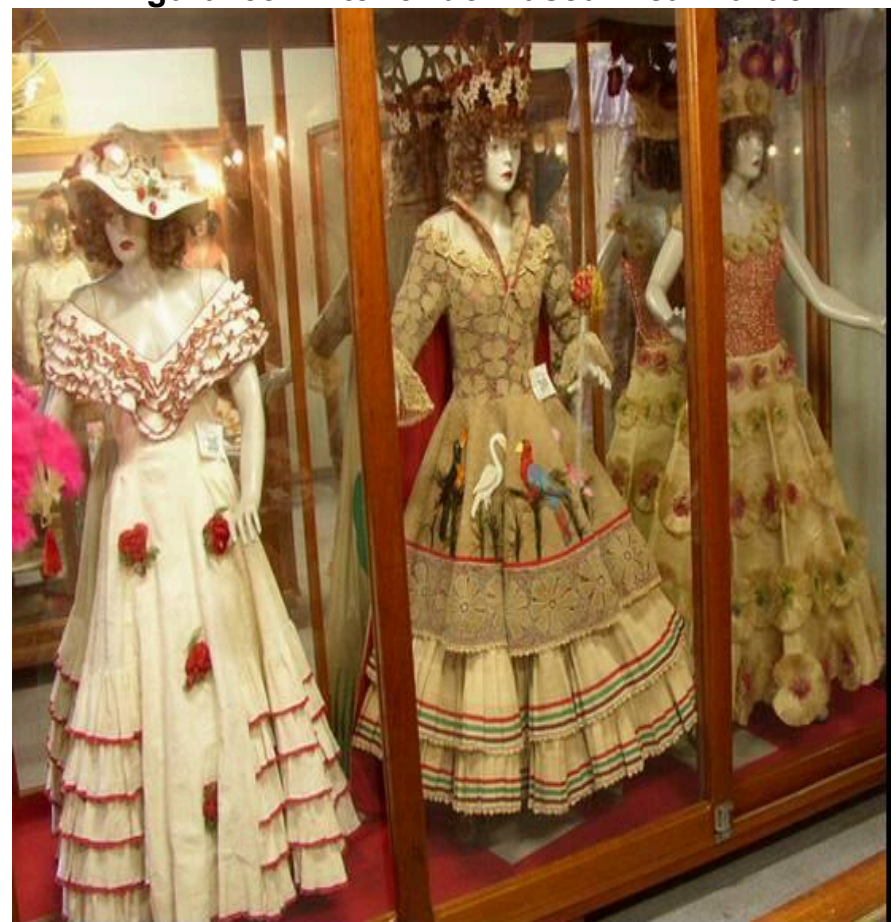

Fonte: http://www.museus.gov.br/tag/museu-dica-frazao

\subsubsection{Outros Patrimônios Edificados}

Figura 40 - Solar dos Campos

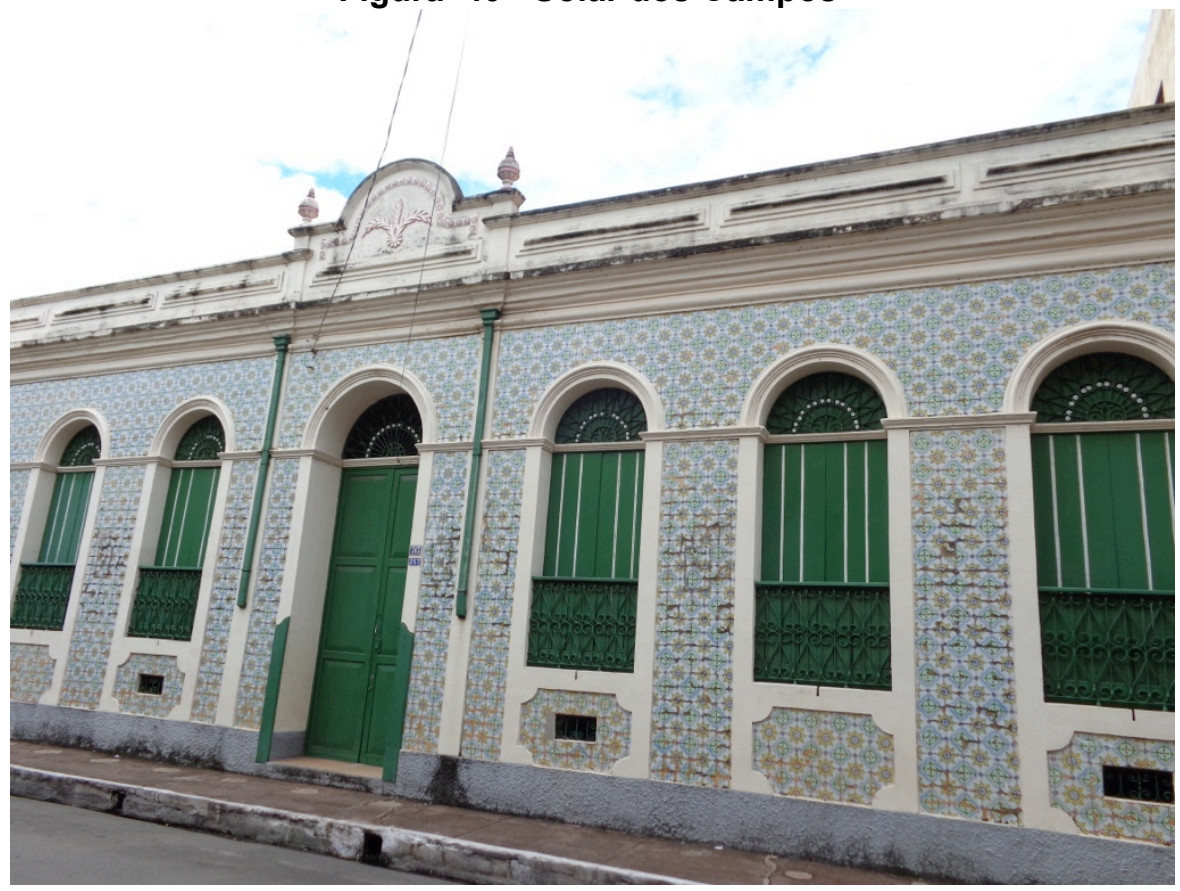

Fonte: Elias Mota 
Figura 41- Edificações Históricas

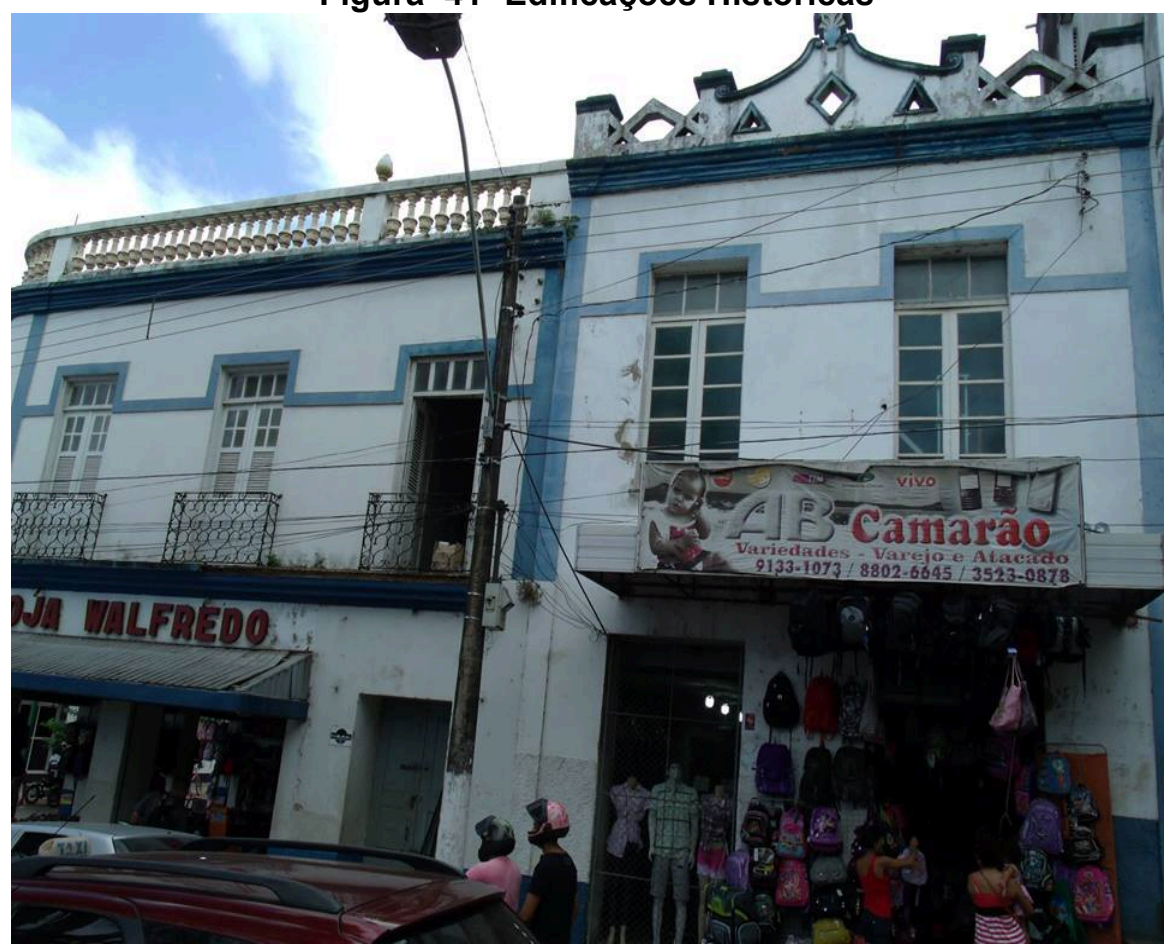

Fonte: Christian Soares

Figura 42- Edificação Histórica I

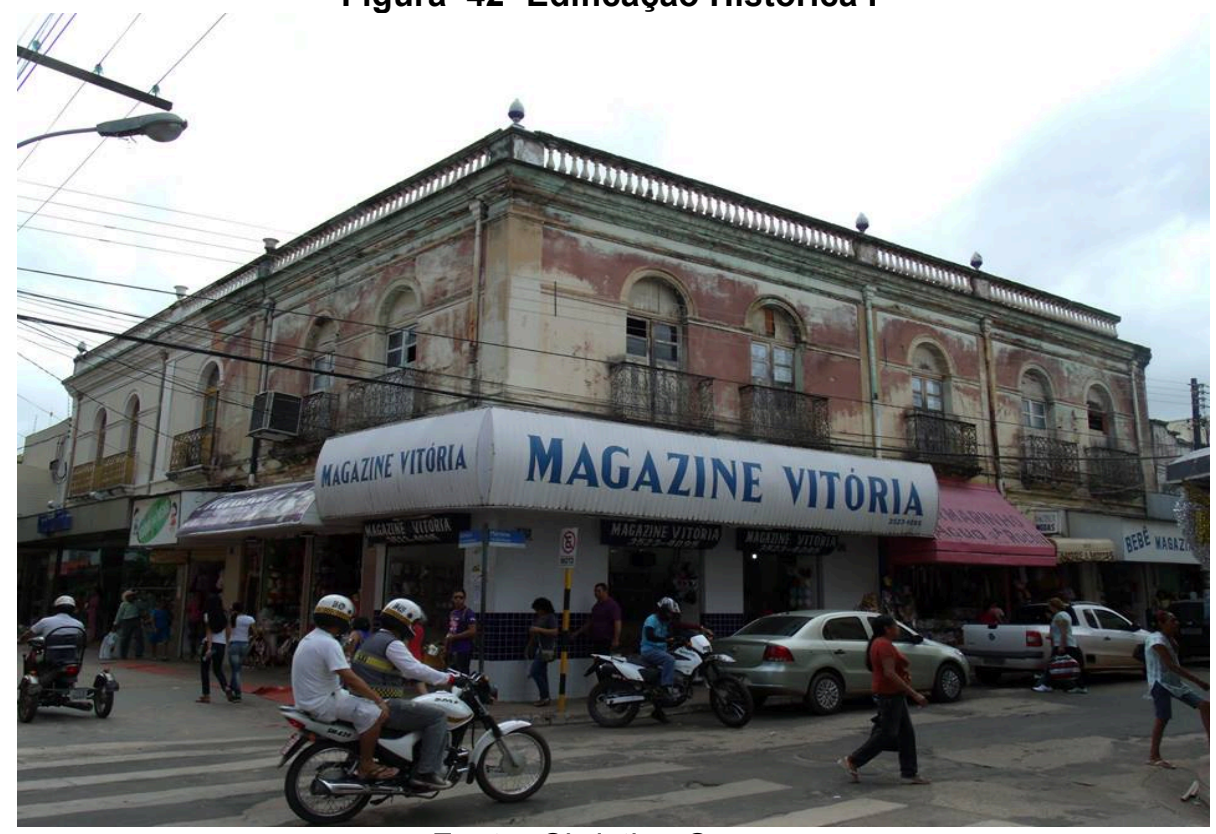

Fonte: Christian Soares 
Figura 43- Solar do Barão de São Nicolau

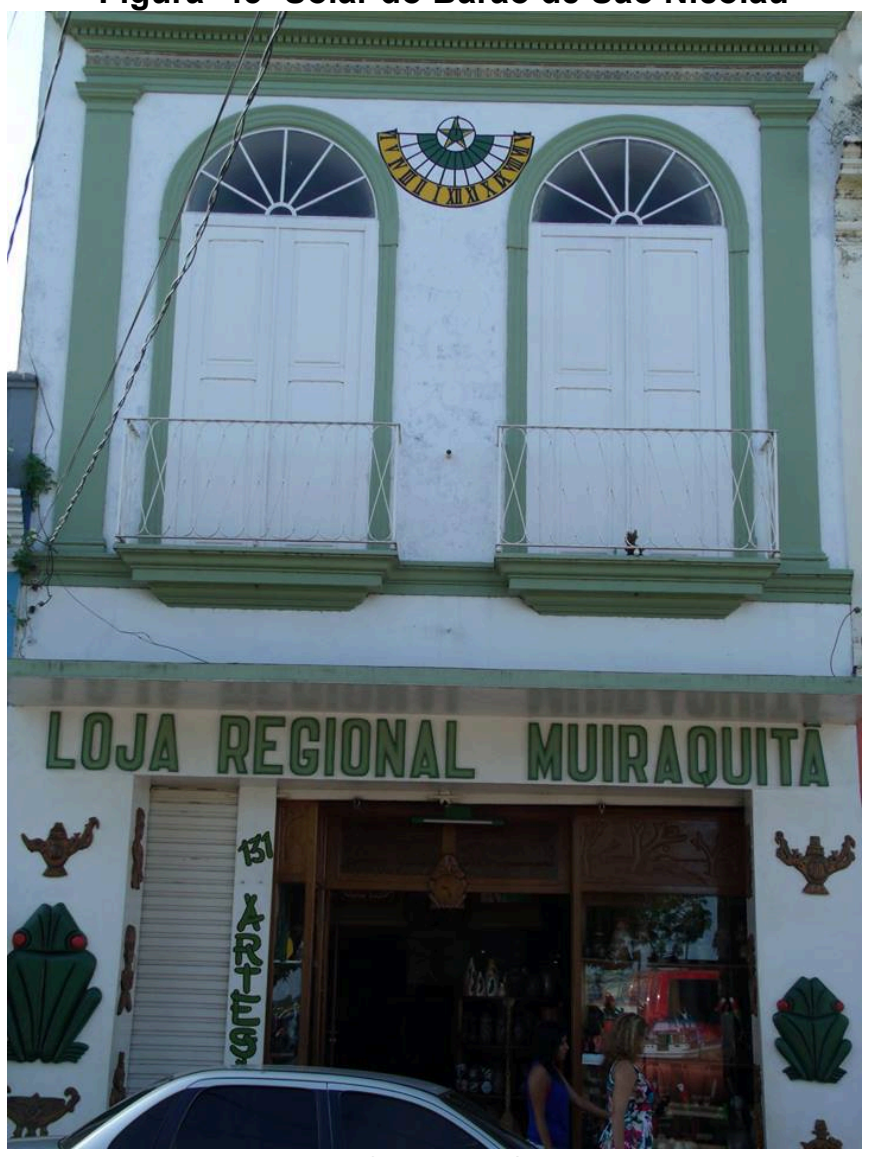

Fonte: Christian Soares

Figura 44 - Fachada do Hotel Alvorada

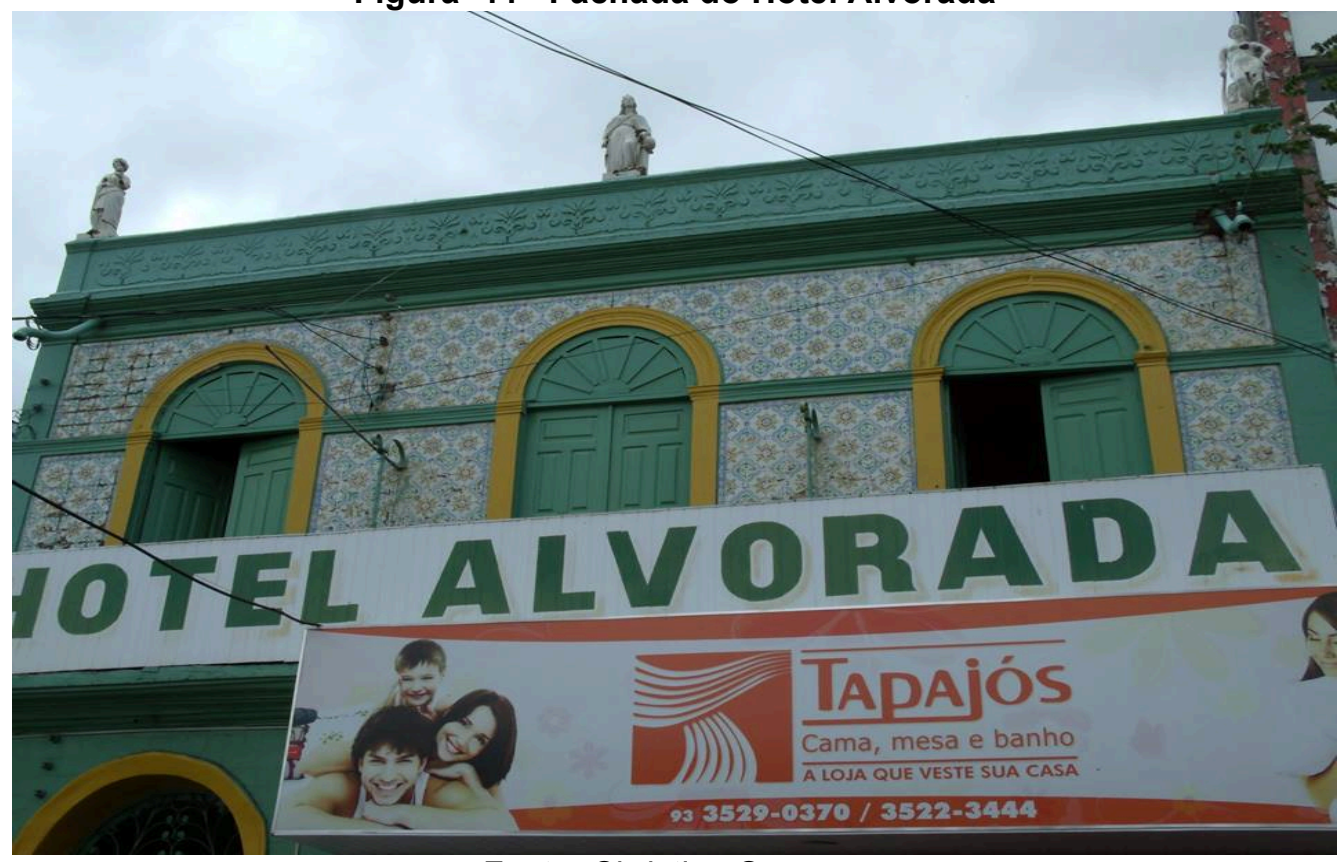

Fonte: Christian Soares 
Figura 45- Edificações Históricas I

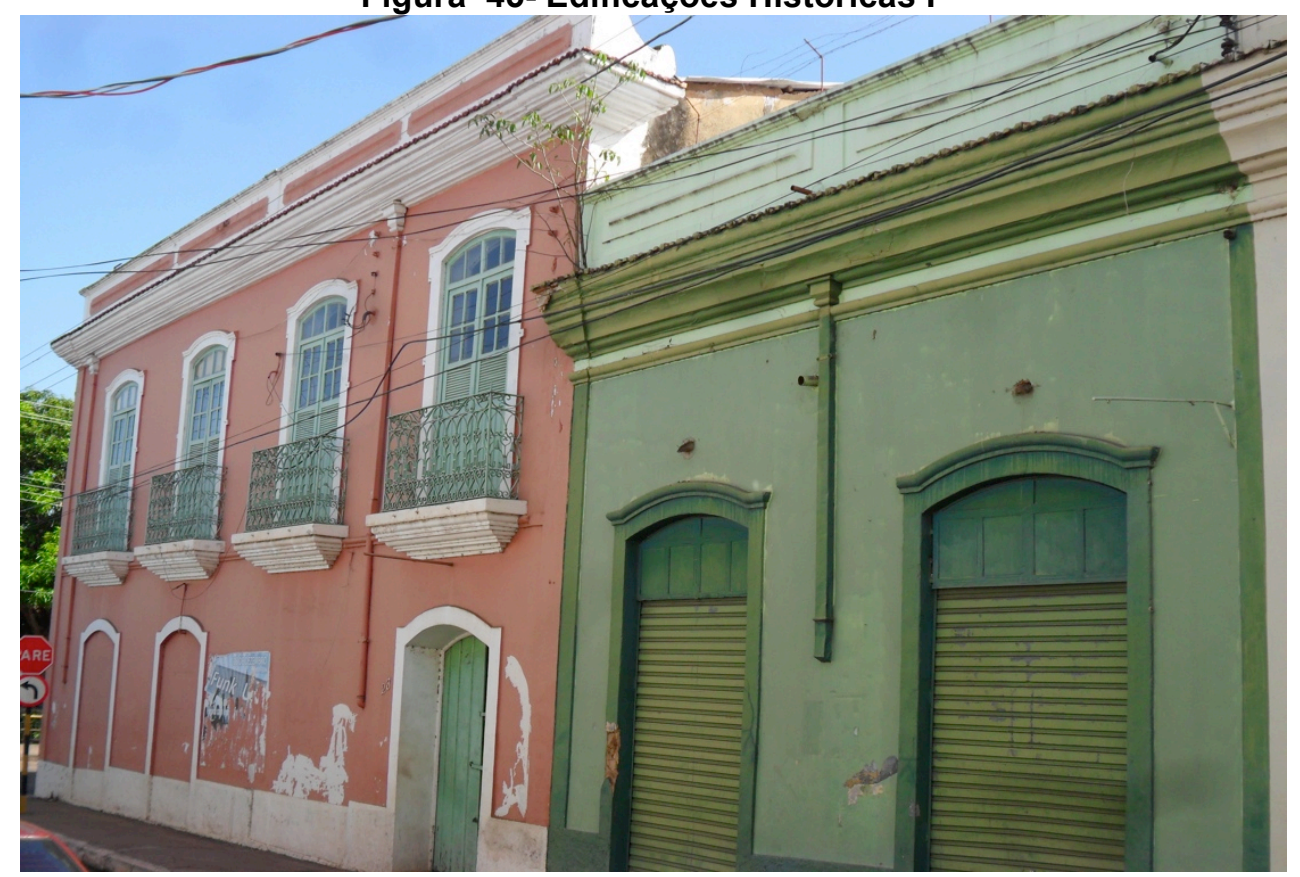

Fonte: Elias Mota

Figura 46 - Sobrados

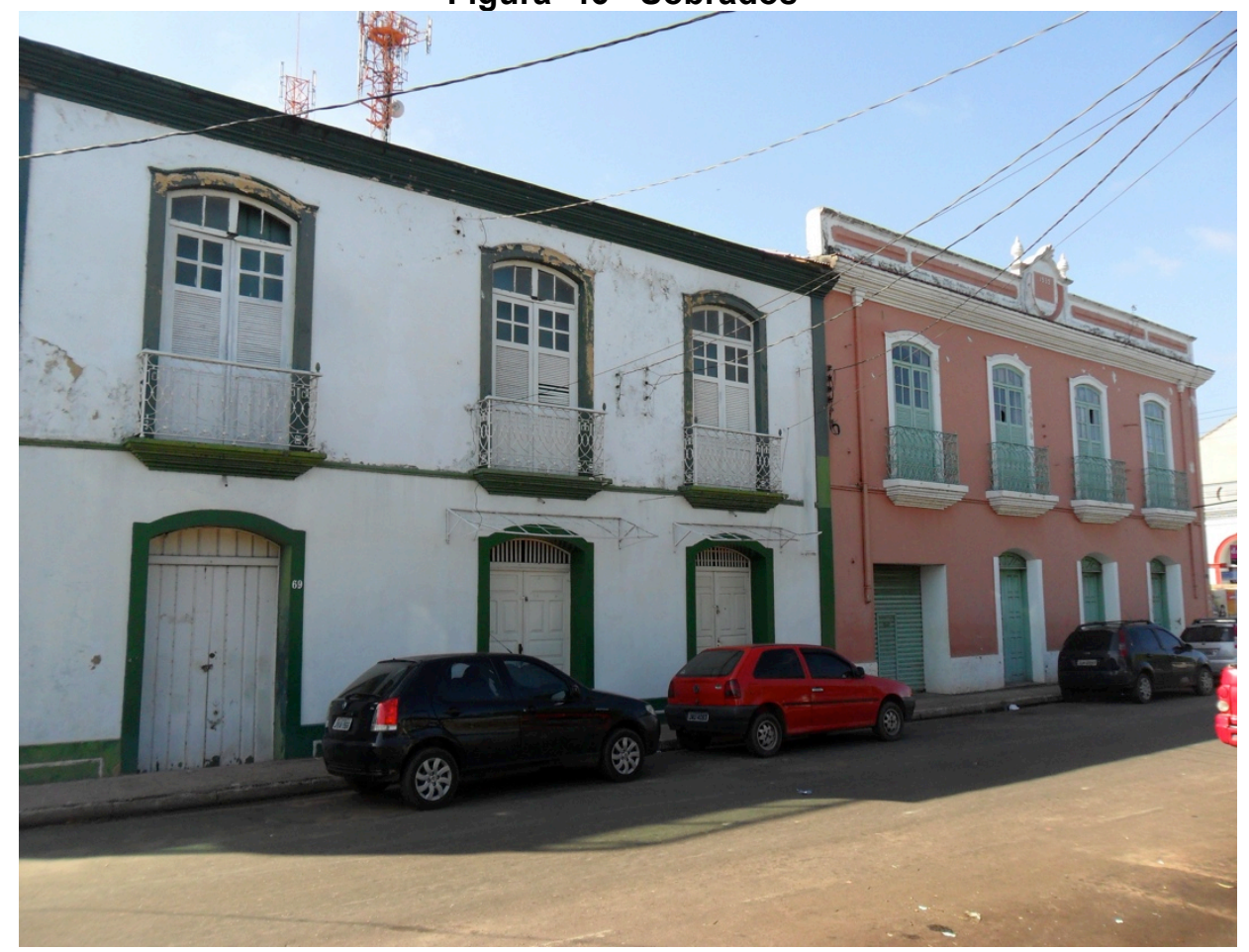

Fonte: Elias Mota 


\section{Figura 47-Sobrados I}

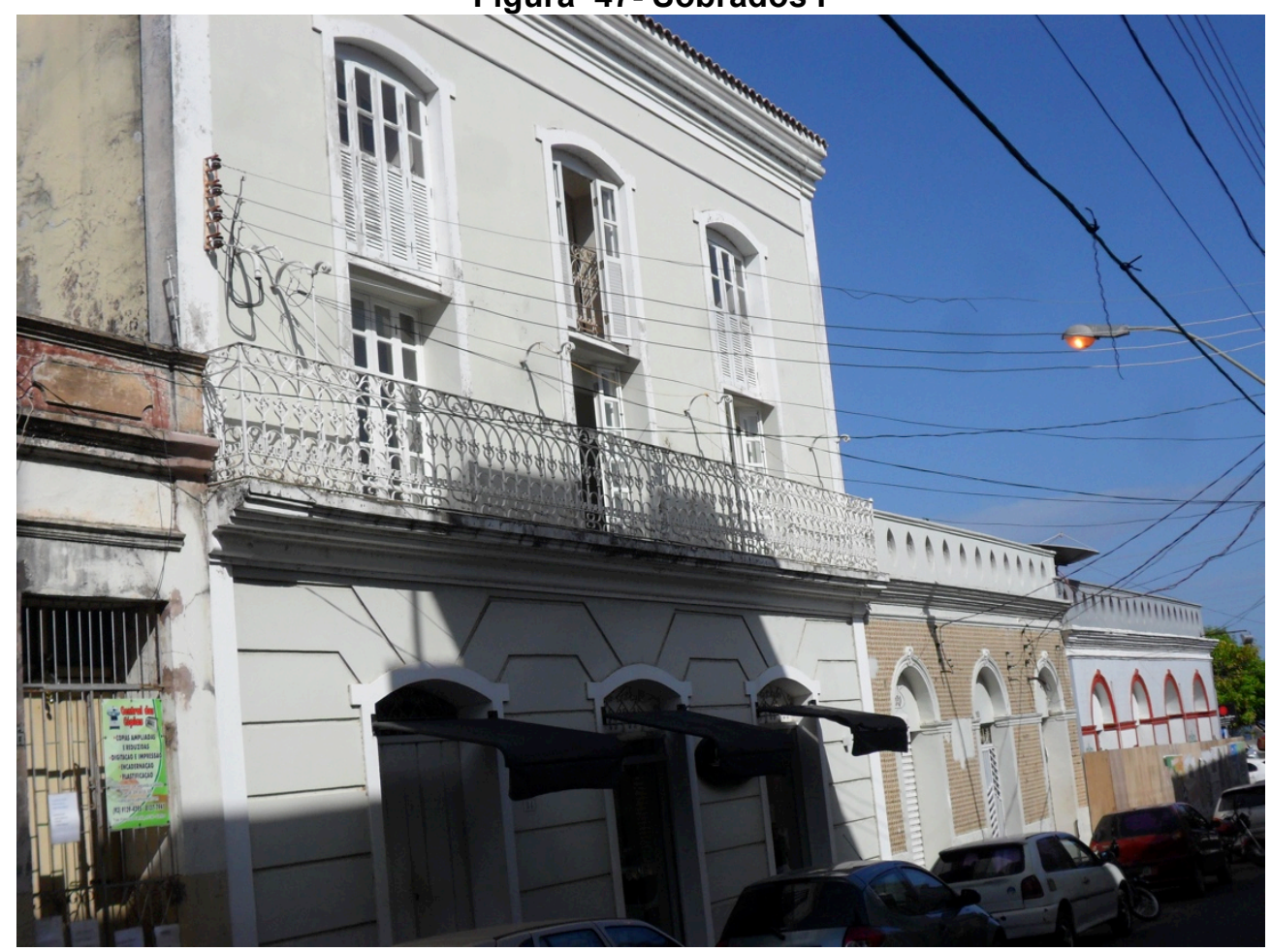

Fonte: Elias Mota

Todos esses Patrimônios Edificados fazem parte da cultura de Santarém que, assim como a memória, estão sujeitos à dinâmica da transformação, significação e ressignificação. Como afirma Bauman (2013), a cultura é fluida. Esse autor sustenta que, com a globalização ou o que ele chama de modernidade líquida, categorias como cultura e identidade não são mais únicas, estáticas, pois não existe uma única cultura ou identidade, tamanha a complexidade que essas categorias representam hoje para os grupos sociais. Assim, é pertinente falar em identidades e não em identidade, quando se fala de Santarém.

Para Meneses (2012, p. 30), "lidar com a memória é entende-la em sua construção, tendo a consciência de que ela é devir, é processo dinâmico e em andamento [...] é representação social, é busca de inserção identitária”.

Os Patrimônios Edificados do Centro Histórico de Santarém fazem parte da construção da cultura ou culturas locais, os quais estão imbricados de sentidos, simbologias e movimento. Como afirma Michel Mafesoli (1996), uma cidade é composta por muito mais do que os esboços e desenhos das ruas e da arquitetura construída, ela mescla fantasias, mistérios e interpretações que seus habitantes fazem dela. A cidade é espaço em construção "por sensações, 
aromas, ruídos, lugares de encontros constitutivos dessa teatralidade cotidiana" (MAFESOLI, 1996, p. 277).

Dessa forma, uma das possibilidades para a preservação e conservação da história, cultura, identidade e memória em Santarém é a Educação Patrimonial, meio que vem sendo utilizado em muitas cidades do Brasil e que será um dos assuntos a ser abordado no capítulo seguinte. 


\section{EDUCAÇÃO PATRIMONIAL E A FORMAÇÃO DO TURISTA CIDADÃO: UMA POSSIBILIDADE EM SANTARÉM}

Conforme a Lei de Diretrizes e Bases da Educação Nacional (LDB) do Ministério da Educação, 2006 n 9394/96, em seu artigo 2º a Educação no Brasil tem por finalidade o pleno desenvolvimento do educando, seu preparo para o exercício da cidadania e sua qualificação profissional (CARNEIRO, 1998).

$O$ desenvolvimento do educando denota a educação como processo intencional, portanto deve contribuir para que o organismo psicológico do aluno se desenvolva numa trajetória harmoniosa e progressiva. Já o exercício da cidadania infere a condição básica de ser cidadão, titular de direitos e deveres a partir de uma condição universal. Por outro lado, a qualificação para o trabalho consiste na necessidade de fazer do trabalho socialmente produtivo elemento de dinâmica escolar (CARNEIRO, 1998).

Neste trabalho, a educação é vista como meio pelo qual o aluno poderá se transformar em sujeito histórico, numa perspectiva crítico-progressista.

Segundo Paulo Freire (2011), uma prática educativa-crítica ou progressista, parte do pressuposto de que "ensinar não é transferir conhecimento, mas criar as possibilidades para a sua produção ou a sua construção" (FREIRE, p. 24). Desse mesmo pensamento, Durkheim apud Morin (2012, p. 47) compartilha, ao afirmar que "o objetivo da educação não é o de transmitir conhecimentos sempre mais numerosos ao aluno, mas o de criar nele um estado interior e profundo [...], que o oriente não somente na infância, mas por toda a vida". Morin (2012, p. 65) completa esta percepção durkheiminiana ao afirmar que "a educação deve contribuir para a autoformação da pessoa (ensinar a assumir a condição humana, ensinar a viver) e ensinar como se tornar cidadão".

Para Freire (2011, p. 25), não há docência sem discência, "quem ensina aprende ao ensinar e quem aprende ensina ao aprender. Quem ensina, ensina alguma coisa a alguém". Nesse processo de interação entre docência e discência, ambos interagem na construção do conhecimento. Esse autor afirma ainda, que "ensinar inexiste sem aprender e vice-versa" (FREIRE, 2011).

$\mathrm{Na}$ perspectiva educacional freireana, o processo se faz entre o que ele chama de educador e educando. Para ele, o processo educativo não se realiza sem essa simbiose. Freire infere que "quando vivemos a autenticidade exigida pela 
prática de ensinar-aprender, participamos de uma experiência total, diretiva, política, ideológica, gnosiológica, pedagógica, estética e ética” (FREIRE, p. 26).

O educador progressista não pode se achar o "dono da verdade", pelo contrário, deve considerar todo o acúmulo histórico-social que o educando traz ao adentrar a escola, onde aprender criticamente é possível. Nesse sentido:

\begin{abstract}
Pensar certo coloca ao professor ou, mais amplamente, à escola, o dever de não só respeitar os saberes com que os educandos, sobretudo os das classes populares chegam a ela, saberes socialmente construídos na prática comunitária [...], por que não aproveitar a experiência que têm os alunos de viver em áreas da cidade descuidadas pelo poder público para discutir, por exemplo, a poluição dos riachos [...], por que não estabelecer uma "intimidade" entre os saberes curriculares fundamentais aos alunos e a experiência social que eles têm como indivíduos? (FREIRE, 2011, p. 31-32).
\end{abstract}

Para Freire, a escola precisa de educadores e educandos com perfis criadores, instigadores, inquietos, rigorosamente curiosos, humildes e persistentes, bem diferente do que ele considera como "educação bancária". Do mesmo pensamento corroboram Weil \& Tompakow apud Demo (2011, p. 22), ao afirmarem que "é preferível um aluno que fala, a outro que se cala, ou que se comunica muito, a outro que se esconde, o que inventa moda, a outro que apenas escuta, ou que é curioso, a outro apático, e assim por diante".

Conforme Demo (2011), é necessário que o aluno saia da condição de objeto a sujeito, onde passa a ser parceiro de trabalho do professor. Nesta perspectiva, o aluno não estará fadado só a escutar as aulas, tomar notas, decorar e fazer provas, mas ser sujeito histórico (que questiona, argumenta, fundamenta, propõe e contrapõe) afinal, para este autor "a educação não é só ensinar, instruir, treinar, domesticar é, sobretudo formar a autonomia crítica e criativa do sujeito histórico competente" (DEMO, 2011, p. 20).

Morin (2012, p. 103) endossa a discussão ao afirmar que:

Formar cidadãos capazes de enfrentar os problemas de sua época é frear o enfraquecimento democrático que suscita, em todas as áreas da política, a expansão da autoridade dos 'experts', especialistas de toda ordem, que restringe progressivamente a competência dos cidadãos. Estes são condenados à aceitação ignorante das decisões daqueles que se presumem sabedores, mas cuja inteligência é míope, porque fracionária e abstrata

A "educação bancária" é tudo de pior que pode existir na escola ou fora dela, afinal não é só na escola que existe educação. É o tipo de educação que não leva em consideração a opinião do aluno, o professor é o detentor do conhecimento, 
enquanto que o aluno só o recebe, serve como depósito de conhecimento, daí a denominação "bancária", como se fosse algo depositado no aluno por outrem, o professor. Nessa concepção, o "educador é o que sabe; os educandos, os que não sabem; o educador é o que pensa; os educandos, os pensados [...], o educador escolhe o conteúdo programático; os educandos, jamais ouvidos nesta escolha, se acomodam a ele" (FREIRE, 2005, p. 68).

A educação crítica ou progressista é o oposto da concepção bancária, enquanto a primeira afirma a dialogicidade e se faz dialógica, aberta, indagadora, crítica, a segunda nega a dialogicidade e "assistencializa".

Enquanto na educação crítica ou progressista os educandos, segundo Freire (2011, p. 28), "vão se transformando em reais sujeitos da construção e da reconstrução do saber ensinado, ao lado do educador, igualmente sujeito do processo", na concepção "bancária”, o aluno é mero receptor, expectador, passivo.

Para Freire, a educação é um processo permanente, em que mulheres e homens se tornam educáveis na medida em que se reconhecem inacabados, inconclusos. Ele sustenta que mulheres e homens são os únicos seres que, social e historicamente, se tornam capazes de apreender, logo são únicos em que "aprender é uma aventura criadora, algo, por isso mesmo, muito mais rico do que meramente repetir a lição dada" (FREIRE, 2011, p. 68).

Nessa perspectiva, aprender, para os humanos, é construção e reconstrução, constatar para mudar, o que está susceptível ao risco (FREIRE, 2011). Ou ainda, segundo Morin (2011, p. 31), "o dever principal da educação é de armar cada um para o combate vital para a lucidez". Para Morin (2011, p. 73), "é preciso aprender com as incertezas, já que vivemos em uma época de mudanças, na qual os valores são ambivalentes, em que tudo é ligado". Assim, a educação do futuro deve atentarse para as incertezas inerentes ao conhecimento.

Outra característica da educação referendada por Freire é seu caráter de intervenção no mundo, onde não se pode ficar neutro, "em cima do muro", pois "a educação jamais foi, é, ou pode ser neutra". Pelo contrário, ela tanto poderá ser usada para reproduzir a ideologia dominante, como o seu desmascaramento. Rego (1995, p. 124) corrobora para o debate, ao afirmar que "a educação, por ser uma prática de intervenção na realidade social, é um fenômeno multifacetado composto por um conjunto complexo de perspectivas e enfoques". Dessa forma, cabe ao professor/educador ter senso crítico, conhecimento necessário do seu papel 
transformador na escola e coragem diante das adversidades no processo de ensino. Nesse sentido, Freire (2011, p. 100) destaca algumas de suas virtudes enquanto professor:

\begin{abstract}
Sou professor a favor da decência contra o despudor, a favor da liberdade contra o autoritarismo, da autoridade contra a licenciosidade, da democracia contra a ditadura de direita ou de esquerda. Sou professor contra qualquer forma de discriminação, contra a dominação econômica dos indivíduos ou das classes sociais [...], sou professor a favor da esperança que me anima apesar de tudo. Sou professor contra o desengano que me consome e imobiliza.
\end{abstract}

A Educação defendida por Freire, Morin e Demo parte do pressuposto de uma construção coletiva do conhecimento entre o professor/educador, o sujeito social e o meio.

Nessa perspectiva educacional, que concebe o indivíduo como sujeito na construção do seu próprio conhecimento, se insere a Educação Patrimonial, uma educação que tem como pressuposto suscitar o conhecimento crítico e o envolvimento da comunidade nas questões referentes à preservação e conservação de seu Patrimônio Cultural.

A Educação Patrimonial de Horta, Grunberg e Monteiro (1999) está em consonância com a Educação dialógica de Freire (2011), na medida em que ambas sustentam o debate permanente, num processo que "estimula e facilita a comunicação e a interação entre as comunidades e os agentes responsáveis pela preservação e estudo dos bens culturais" (HORTA, GUNBERG e MONTEIRO, 1999, p. 6), em uma permuta de conhecimentos.

A Educação Patrimonial tem seu marco inicial no Brasil em 1983, no Museu Imperial, Petrópolis-RJ, através de um Seminário que tratou de sua utilização, naquele momento, em museus e monumentos, tendo inspiração no trabalho pedagógico desenvolvido na Inglaterra, sob a designação Heritage Education (HORTA; GRUNBERG; MONTEIRO, 1999).

Após a introdução da Educação Patrimonial no Brasil, várias ações foram implementadas e o Guia Básico de Educação Patrimonial desenvolvido por Horta, Grunberg e Monteiro, em 1999, veio definir o conceito, a metodologia e as atividades da Educação Patrimonial. Esta obra é um documento que institucionaliza a Educação Patrimonial no Brasil, serve como parâmetro das atividades desenvolvidas por profissionais de diferentes áreas e constitui-se hoje, passados mais de 30 anos, 
como base para ações de Educação Patrimonial desenvolvidas em várias partes do país.

A Educação Patrimonial (1999), assim como a educação defendida por Morin (2011), é um sistema aberto onde todos os públicos podem ser contemplados (da criança ao idoso), não podendo ser vista de forma fragmentada, isolada, mas integradora, participativa e libertadora.

Nessa ordem de pensamento, falar de Educação Patrimonial é falar da educação libertadora nos termos de Freire (2011), na medida em que o aluno/educando se torna sujeito ativo no processo educacional. Quando este assume uma postura questionadora, sensível às questões de sua cultura e sua identidade, ele se conscientiza e passa a conscientizar, se assumindo como sujeito histórico, pleno e cidadão.

Dessa forma, a convergência entre Freire, Morin e Demo acerca da educação apontam para a autonomia do aluno/educando como sujeito não acabado, mas em processo de transformação contínuo - tanto no contexto social, econômico, cultural e histórico - na construção de uma sociedade melhor, pois como afirma Morin (2012, p. 11), “a educação pode ajudar a nos tornarmos melhores, se não mais felizes".

A Educação Patrimonial é um processo contínuo de conhecimento baseado na preservação, conservação, conscientização e sensibilização do Patrimônio Cultural (material e imaterial). Trata-se de um meio que pode ser trabalhado, tanto para crianças, jovens, adultos e idosos, constituindo-se, dessa forma, num processo multidisciplinar e aberto a todos os públicos, devendo ser adaptada à realidade de cada comunidade onde for desenvolvida. Aliás, a comunidade é peça fundamental, pois é ela que elege o que deve ser considerado como seu Patrimônio. Dias \& Soares (2007, p. 69) colaboram para o debate ao afirmarem que "antes de qualquer coisa é preciso possibilitar ao educando que perceba sua condição na sociedade e que escolha o que deve ser eleito como patrimônio". Os mesmos autores inferem ainda que "é preciso uma educação que dê autonomia, uma educação libertadora [...], uma educação que permita aos educandos elegerem seus patrimônios de acordo a representatividade dos mesmos em suas realidades" (DIAS \& SOARES, 2007, p. 72-73).

Florêncio (2012, p. 29), utilizando-se de uma premissa Freireana, destaca em seu artigo, Educação Patrimonial: um processo de mediação, que a "Educação 
Patrimonial pode ser uma importante ferramenta na afirmação de identidades e para que as pessoas se assumam como seres sociais e históricos, como seres pensantes, comunicantes, transformadores, criadores".

Nessa perspectiva, Itaqui (1998) afirma que:

O trabalho da Educação Patrimonial é levar os indivíduos a um processo ativo de conhecimento, apropriação e valorização de sua herança cultural, capacitando-os para uma melhor utilização destes bens e propiciando a geração e a produção de novos conhecimentos, tendo assim um contínuo processo de criação cultural (ITAQUI, 1998, p. 20).

Scifoni (2012) sustenta que a Educação Patrimonial pode ser compreendida como um campo ampliado de atuação, não se limitando à visitação a museus ou Bens Patrimoniais, mas diversificando ações educativas onde a participação da população local é primordial. Essa inclusão se faz necessária, pois é ela que elege seus bens referenciais.

Para as autoras do Guia Básico de Educação Patrimonial Horta, Grunberg e Monteiro (1999, p. 6), "trata-se de um processo permanente e sistemático de trabalho educacional centrado no patrimônio cultural como fonte primária de conhecimento e enriquecimento individual e coletivo".

Nessa perspectiva, a Educação Patrimonial para a escola Frei Ambrósio poderá trazer resultados positivos acerca de assuntos que envolvam Patrimônio, cultura, identidade, memória e cidadania, pois, como afirma Sales (2006, p. 41), ao proporcionar "às pessoas de estar em contato com o seu passado, história e raízes, estar-se-ia oportunizando que as mesmas construam relações afetivas com seu legado cultural".

A Educação Patrimonial, como processo contínuo de ensino centrado no Patrimônio Cultural, pode ser um instrumento de mudança de comportamento e atitudes por parte dos alunos/educandos, pois ao se tornarem sujeitos conscientes, esclarecidos sobre sua história, cultura e cidadania, poderão reaplicar esse conhecimento a outros indivíduos.

A informação e compreensão dos fatos, das coisas, do contexto social são imprescindíveis para uma educação do século XXI. Conforme Morin (2011, p. 82), "a informação, se for bem transmitida e compreendida, traz inteligibilidade, condição primeira necessária, mas não suficiente, para a compreensão". O teórico frisa que "ensinar a compreensão entre as pessoas como condição e garantia da solidariedade intelectual e moral da humanidade", torna-se essencial para uma 
educação do futuro. "Compreender inclui, necessariamente, um processo de empatia, de identificação" (MORIN, 2011, p. 82). Dessa forma, a identificação do aluno/educando com seu patrimônio cultural poderão transformar-se, com o tempo, em pertencimento.

A Coordenação de Educação Patrimonial (CEDUC), do Instituto do Patrimônio Histórico e Artístico Nacional (IPHAN), em publicação de 2014, intitulada Educação Patrimonial: histórico, conceitos e processos, afirma que:

\begin{abstract}
A Educação Patrimonial constitui-se de todos os processos educativos formais e não formais que tem como foco o Patrimônio Cultural, apropriado socialmente como recurso para a compreensão sócio-histórica das referências culturais em todas as suas manifestações, a fim de colaborar para seu reconhecimento, sua valorização e preservação. Considera ainda que os processos educativos devem primar pela construção coletiva e democrática do conhecimento, por meio do diálogo permanente entre os agentes culturais e sociais e pela participação efetiva das comunidades detentoras e produtoras das referências culturais, onde convivem diversas noções de Patrimônio Cultural (IPHAN, 2014, p. 19).
\end{abstract}

Para Cerqueira (2008), um dos principais objetivos que motivam a Educação Patrimonial é, sem dúvida alguma, seu caráter inclusivo, o fomento à autoestima das comunidades envolvidas, estimulando o conhecimento e valorizando seu Patrimônio. Esse autor, sustenta ainda que "de forma idealista, podemos imaginar que a Educação Patrimonial seja um instrumento importante para a construção de uma democracia cultural em escala planetária, baseada em formas de cidadania" (CERQUEIRA, 2008, p. 14).

Pensar a Educação Patrimonial para a escola Frei Ambrósio é compreender que o conhecimento é capaz de trazer novos olhares, novas posturas e múltiplas possibilidades para serem inseridas no cotidiano dos alunos/educandos no que se refere aos Bens Patrimoniais; é ter compreensão que a educação não é para domesticar, mas é para libertar, não é para alienar e sim oferecer autonomia (FREIRE, 2011).

O educando consciente, sujeito de sua história, partícipe dos problemas sociais de sua comunidade, das dificuldades enfrentadas pelos professores - como baixos salários, sem formação continuada, com uma carga horária que o impõe a ter que trabalhar em várias escolas em turnos diferentes ou em turmas multisseriadas, etc. - pode ser um aliado na construção de uma educação menos excludente e com equidade.

Uma Escola Cidadã conforme Paulo Freire apud Gadotti (2010, pp. 11-12): 
É aquela que se assume como centro de direitos e deveres. O que a caracteriza é a formação para a cidadania. A Escola Cidadã, então, é a escola que viabiliza a cidadania de quem está nela e de quem vem a ela. Ela não pode ser uma escola cidadã em si e para si. Ela é cidadã na medida mesma em que se exercita na construção da cidadania de quem usa o seu espaço. A Escola Cidadã é uma escola coerente com a liberdade. É coerente com o seu discurso formador, libertador. É toda escola que, brigando para ser ela mesma, luta para que os educandos-educadores também sejam eles mesmos. E como ninguém pode ser só, a Escola Cidadã é uma escola de comunidade, de companheirismo. É uma escola de produção comum do saber e da liberdade. É uma escola que vive a experiência tensa da democracia.

Difundir a Educação Patrimonial na escola é instigar a curiosidade do educando acerca de sua história e cultura, entendida por Horta, Grunberg e Monteiro (1999, p. 7) como "um processo eminentemente dinâmico, transmitido de geração em geração, que se aprende com os ancestrais e se cria e recria no cotidiano do presente". É possibilitar ao educando ferramentas para que ele ao passar em frente ou adentar a um bem patrimonial faça uma leitura diferenciada, crítica, sensível, da qual faz parte como cidadão.

Em artigo intitulado Educação Patrimonial: uma análise conceitual, Magalhães (2009, p. 69) infere que:

A Educação Patrimonial deve ser entendida como um instrumento de afirmação da cidadania, envolver a comunidade, levando-a a apropriar-se e usufruir do patrimônio, capacitar o indivíduo para a leitura e compreensão do universo sócio-cultural que está inserido, produzir novos conhecimentos, possibilitando um enriquecimento individual, coletivo e institucional, tornar accessível instrumentos para leitura crítica dos bens culturais em suas múltiplas manifestações, fortalecer a identidade cultural, entender a cultura brasileira como múltipla e plural e estimular o diálogo com órgãos responsáveis.

A Educação Patrimonial, conforme o guia básico (1999), tem uma metodologia criada em princípio para ser desenvolvida em museus, porém, com o passar do tempo, foi ressignificada e adaptada a cada contexto social a qual é utilizada, e compreende 04 etapas:

a) Observação através de exercícios de percepção visual/sensorial, objetivando a identificação do objeto/função/significado e o desenvolvimento da percepção visual e simbólica;

b) Registro do objeto através de desenho, descrição verbal ou escrita, gráficos, fotografias, maquetes, mapas e plantas baixas objetivando a fixação do conhecimento percebido, aprofundamento da observação e análise crítica e o desenvolvimento da memória, pensamento lógico, intuitivo e operacional.

c) Exploração através da análise do problema, levantamento de hipóteses, discussão, questionamento, avaliação, pesquisa em fontes como bibliotecas, arquivos, cartórios, instituições, jornais e entrevistas com objetivo do 
desenvolvimento das capacidades de análise e julgamento crítico, interpretação das evidências e significados.

d) Apropriação do objeto através da recriação, releitura, dramatização, interpretação em diferentes meios de expressão como pintura, escultura, drama, dança, música, poesia, texto, filme e vídeo objetivando o envolvimento afetivo, internalização, desenvolvimento da capacidade de auto-expressão, apropriação, participação coletiva e valorização do bem cultural (HORTA; GRUNBERG; MONTEIRO, 1999, p.11).

Dessa forma, cabe ao professor/educador a utilização dos passos necessários à efetivação das ações de Educação Patrimonial, considerando a realidade local.

Evelina Grunberg (2007) publicou o Manual de atividades práticas de Educação Patrimonial, no qual elenca várias sugestões de ações que podem ser realizadas como, por exemplo, a visitação a uma edificação (museu, igreja, casarão, mercado, edifício público ou privado, escola) e, a partir daí, desenvolver atividades com o público participante.

Outra sugestão é uma caminhada pelo Centro Histórico de uma cidade, a fim de saber qual a percepção do público envolvido acerca do Patrimônio Edificado, as fachadas, conversar com os transeuntes sobre a importância da preservação e conservação do bem edificado, observar o estado em que se encontram os bens do roteiro, se estão cuidados ou abandonados, etc.

Acerca da metodologia da Educação Patrimonial Horta, Grunberg e Monteiro (1999) afirmam que ela pode ser utilizada a qualquer evidência material ou imaterial da cultura, "seja um objeto ou conjunto de bens, um monumento ou sítio histórico, uma paisagem natural [...], um centro histórico urbano [...], qualquer expressão resultante da relação entre indivíduos e seu meio ambiente" (HORTA, GRUNBERG e MONTEIRO, 1999, p. 6).

Sabe-se que existem hoje no Brasil várias ações de Educação Patrimonial desenvolvidas de norte a sul do país e, apesar do Rio de Janeiro ser o Estado pioneiro neste processo, é no sul do país que as experiências de Educação Patrimonial demonstram campo fértil.

Sobre a expansão da Educação Patrimonial pelo Brasil, Horta (2005, p. 221) afirma:

A proposta da Educação Patrimonial se expandiu e criou raízes cujos frutos vêm sendo colhidos com sucesso e entusiasmo nas múltiplas experiências educacionais, patrimoniais e comunitárias em que esse instrumento foi utilizado, e a partir das quais foi enriquecido e consolidado, com a contribuição de inúmeros profissionais e atores no campo da cultura e do patrimônio cultural. 
A exemplo, temos o que ocorreu nos quatro sítios arqueológicos no Rio Grande do Sul: São Miguel Arcanjo, São Nicolau, São João Batista e São Lourenço Mártir. A Educação Patrimonial foi introduzida em 1987 nessas localidades e tem sido fundamental no entendimento, por parte das comunidades que habitam esses sítios. Ela tem mostrado a importância histórica e a necessidade da preservação e valorização desses locais. Uma das metodologias da Educação Patrimonial desenvolvida foi uma oficina arqueológica.

Outra experiência de utilização da Educação Patrimonial aconteceu no Centro Histórico de Antônio Prado no Rio Grande do Sul, em 1989. Trata-se de uma oficina de Educação Patrimonial, a qual faz parte de um processo de sensibilização da população para a valorização de seu Patrimônio Cultural. A oficina realizada em Antônio Prado, ocorreu durante um encontro regional de museus e arquivos históricos e envolveu a Secretaria Municipal de Educação, técnicos do Iphan e professores que abordaram temas como a evolução urbana do município no seu espaço geográfico e histórico; o início da colonização que abordou a vida econômica, política e social fazendo uma comparação com o município hoje e a casa da Dona Neni (residência típica da região, trata-se de casarão de madeira que abrigou os primeiros imigrantes italianos que chegaram a Antônio Prado). Os participantes tiveram como base a reorganização do museu da cidade e elaboraram propostas de trabalho a serem desenvolvidas nas escolas, vivenciaram metodologias de educação patrimonial como: folhas didáticas para dar suporte a uma caminhada pelo centro histórico, a exploração do acervo do museu e também foi elaborada uma coletânea de receitas típicas italianas, jogos e uma revista em quadrinhos abordando o conflito entre a preservação e o desenvolvimento da cidade.

A experiência da Quarta Colônia de Imigração Italiana, também no Rio Grande do Sul, constitui-se em um dos mais bem sucedidos exemplos de Educação Patrimonial já posto em prática no Brasil. Trata-se de um projeto regional que foi desenvolvido pela Secretaria de Cultura e Turismo de Silveira Martins/RS, a partir de 1993, abrangendo o sistema educacional dos municípios da região. O projeto teve a duração e três anos e desenvolveu uma metodologia específica para o trabalho da Educação Patrimonial na área rural. A metodologia utilizada partiu de uma oficina de Educação Patrimonial e desenvolveu-se junto a professores locais que, a partir da 
coleta, identificação e análise da cultura material e da tradição oral do município trabalharam temáticas como: a casa, espaços e mobiliários, documentos familiares, entre outros, para servirem de objeto de estudo e exploração envolvendo todas as disciplinas do currículo, a partir de observação, coleta, pesquisa e exploração, tendo como referencial o quotidiano dos alunos. Ao final de cada etapa, organizou-se, em cada escola, uma exposição dos resultados coletados e trabalhos realizados (desenhos, maquetes, fotografias, mapas, relatos, dramatizações).

$\mathrm{Na}$ atualidade, existem muitos projetos espalhados pelo Brasil. Há projetos de Educação Patrimonial no Norte (Belém e Óbidos/PA); no Nordeste, em cidades como: João Pessoa/PB, Nova Olinda/CE, Recife/PE; no Sudeste: Ouro Preto/MG, Vale do Ribeira/SP, Região dos Lagos/RJ e; no Centro-Oeste: Goiás/GO. No entanto, há carência de literatura na área, o que sinaliza a necessidade de outras pesquisas em relação à Educação Patrimonial. O Iphan, como órgão fomentador e norteador de ações voltadas a temática de Educação Patrimonial, já disponibiliza, em seu site, alguns textos acerca da Educação Patrimonial e suas interfaces.

O pesquisador Soares (2003) organizou uma publicação intitulada Educação Patrimonial: relatos e experiências, editada pela Universidade Federal de Santa Maria (UFSM/RS), com uma série de artigos sobre o projeto-piloto Interface para a valorização da Memória e Identidade Cultural em São Martinho da Serra, RS: um programa de Educação Patrimonial. Outra publicação importante para o avanço da Educação Patrimonial em nosso país foi organizada por Klamt e Soares (2007), como o título Educação Patrimonial: teoria e prática. A obra reúne artigos que utilizaram a metodologia da Educação Patrimonial com experiências em escolas ou instituições de ensino, com professores e alunos.

Em 2010, no Estado de Goiás a pesquisadora Pires organizou o livro intitulado Educação Patrimonial Memória e Identidades da cidade de Goiás: patrimônio pra que te quero!, editado pelo IPHAN. A obra relata experiências de Educação Patrimonial em escolas da rede pública do ensino fundamental. Foi um projeto desenvolvido em três etapas voltado para 150 professores.

Todas as experiências de Educação Patrimonial desenvolvidas de norte a sul do país são exemplos de que esse processo é uma realidade no Brasil, e de como os resultados são animadores em relação a mudanças de atitudes $\mathrm{e}$ comportamentos em relação ao Patrimônio Cultural. 
Pensar em Educação Patrimonial para a Escola Frei Ambrósio, como tema transversal, é acreditar na possibilidade de mudança de atitudes e comportamentos de seus alunos para um olhar consciente, cuidadoso de seus bens patrimoniais e sujeitos de sua história. É acreditar que, através dessa metodologia de ensino, os alunos possam assumir uma consciência cidadã, pois como postulam Klamt e Soares (2007, p. 191), “a Educação Patrimonial visa a formação de uma consciência cidadã, na qual todos os cidadãos brasileiros em um processo de inclusão sociocultural, alicerçado sobre a diversidade como riqueza do país". Dessa forma, a Educação Patrimonial poderá ser um meio, um canal na construção de ações para a preservação e conservação dos bens patrimoniais no Centro Histórico de Santarém.

A Educação Patrimonial sugere a educação do olhar. Para Cardoso (1998), ver é diferente de olhar. Enquanto o ver suscita no vidente reserva, discrição, passividade, docilidade e desatenção, o olhar, por sua vez é intencional, atento, tenso e alerta. O teórico infere que "na verdade, entre o ver e o olhar é a própria configuração do mundo que se transforma" (CARDOSO, 1998, p. 348). Nessa perspectiva, o educando que consegue ter esse entendimento acerca do patrimônio cultural de sua cidade poderá se conscientizar e se sensibilizar acerca da preservação e conservação da sua história e identidade.

Ao assumir sua identidade, através também das construções antigas situadas no Centro Histórico de Santarém, o aluno experimenta algo novo, uma experiência que ainda não havia sido vivenciada, em que poderá, a partir de então, ter um olhar diferenciado daquela edificação, antes vista como feia, estática, velha, sem utilidade. Por outro lado, ao se identificar com o bem patrimonial, ver esse bem como de todos e ter a noção de pertencimento, esse aluno poderá ser forte aliado na preservação e conservação do Patrimônio Edificado.

O aluno que tem conhecimento acerca de sua história, cultura e Bens Patrimoniais poderá se tornar um indutor/disseminador do que aprende na escola para outros ambientes como: sua casa, igreja, comunidade, etc.

A experiência da identificação cultural é uma das várias possibilidades de identidade que o aluno poderá assumir na escola, para outros ambientes por onde transita. Para Bauman (2005, p. 91), "a construção da identidade assumiu a forma de uma experimentação infindável onde os experimentos jamais terminam". Nessa perspectiva, o aluno consciente, crítico e sensibilizado para a preservação e 
conservação dos bens patrimoniais de sua cidade poderá sempre estar aberto a novas descobertas na construção de sua identidade cultural e social.

Conforme Cardoso (1998, p. 349), "o olhar pensa; é a visão feita de interrogação". Dessa forma, levar o educando ao conhecimento questionador, a ter um olhar atento e alerta acerca de seus bens patrimoniais, poderá constituir consciência crítica. Bosi (1998, p. 78) infere que "olhar [...] é, tantas vezes, sinônimo de cuidar, zelar, guardar". Logo, o educando conhecedor de sua história, cultura e Bens Patrimoniais estará mais propenso a atitudes de preservação e conservação do Patrimônio de sua cidade.

Para Merleau-Ponty apud Novaes (1998, p. 15), "todo o saber se instala nos horizontes abertos pela percepção". Nessa perspectiva, o educando que sai da sala de aula para uma visita técnica a um museu, um prédio antigo ou a uma igreja; ou que através de um projeto desenvolvido pela escola sobre patrimônio cultural, tem acesso à informação e, por conseguinte, pode produzir conhecimento acerca desses temas e ser capaz de formar um olhar crítico, questionador, curioso, perceptivo.

O aluno da Escola Frei Ambrósio que participa de projetos culturais, que sai da sala de aula para visitar seus bens patrimoniais, que tem conhecimento acerca de sua história, que sabe da importância de determinado casarão histórico para a cultura, história, identidade e memória de sua cidade, está no caminho para a construção de sua cidadania e de sua formação enquanto sujeito histórico. Mas é necessário que esse aluno queira assumir-se como sujeito histórico, questionador, crítico e curioso.

Santo Agostinho apud Chaui (1998, p. 34) infere que "a curiosidade [...] é afecção primordial dos olhos", o que corrobora com os ensinamentos de Freire (2011), ao ressaltar que a curiosidade é pedra fundamental na vida do ser humano, pois é ela que leva ao questionamento, a conhecer e re-conhecer. Freire sustenta ainda, que "o exercício da curiosidade convoca a imaginação, a intuição, as emoções, a capacidade de conjecturar, de comparar" (FREIRE, 2011, p. 85).

Novaes (1998) lança a seguinte indagação: a vista é o que nos faz adquirir mais conhecimentos e, dessa forma, descobrir mais diferenças? Acredita-se que sim, pois é através do olhar que as ideias são construídas, as opiniões são formadas, o conhecimento se mostra, se explicita. Nessa perspectiva, Chaui (1998, p. 35) ressalta que "ver é olhar para tomar conhecimento e para ter conhecimento" e 
ainda "a aptidão da vista para o discernimento é o que nos faz descobrir mais diferenças" (CHAUI, 1998, p. 38).

\subsection{O Turismo e o Turista Cidadão: relações com a Educação Patrimonial}

O Turismo moderno, como conhecemos hoje, tem seu início no século XIX e vem se modificando com o passar dos anos, tornando-se uma atividade cada vez mais multidisciplinar e dinâmica. Conforme Dias (2002, p. 21), "a palavra turismo deriva do latim tornus, substantivo que significa a ação de movimento e retorno, e que dá origem a tornare, girar". Para o teórico, o turismo denota a ideia de ida e volta, nesse sentido o retorno é essencial.

Segundo a Organização Mundial do Turismo (OMT) (2001, p. 38), “o Turismo compreende as atividades que realizam as pessoas durante suas viagens e estadas a lugares diferentes ao seu entorno habitual, por um período consecutivo inferior a um ano, com finalidade de lazer, negócios e outras". Há de se ressaltar nessa definição ampla e flexível do órgão oficial mundial algumas características importantes quando se realiza turismo, a saber: os elementos motivadores da viagem (lazer, saúde, cultura, religião, natureza, etc), o tempo máximo de um ano, a delimitação da atividade desenvolvida antes e durante o período de estada e o deslocamento para fora do seu entorno habitual. Para a OMT (2001, p. 38), "o entorno habitual de uma pessoa consiste em certa área que circunda sua residência mais todos aqueles lugares que visita frequentemente". A definição de turismo para o MTur é a mesma adotada pela OMT.

Para Barretto (2012), o turismo é movimento de pessoas, é um fenômeno que envolve, antes de tudo, gente. Portanto, para essa autora, a essência do Turismo, na atualidade, acontece quando se estabelecem relações múltiplas entre visitantes e visitados. A sociedade, que antes era sedentária, hoje é movimento (KRIPPENDORF, 2003). Na mesma publicação de Margarita Barretto (2012, p. 13) encontra-se uma definição do mexicano Oscar de La Torre para o fenômeno turístico, que se aproxima do objeto de estudo dessa dissertação ao afirmar que:

O turismo é um fenômeno social que consiste no deslocamento voluntário e temporário de indivíduos ou grupos de pessoas que, fundamentalmente por motivos de recreação, descanso, cultura ou saúde, saem do seu local de residência habitual para outro, no qual não exercem nenhuma atividade 
lucrativa nem remunerada, gerando múltiplas inter-relações de importância social, econômica e cultural.

Ao analisar as definições oficiais e a de De La Torre, pode-se afirmar que existem confluências, ambos afirmam que: há a existência de um movimento físico dos turistas, os turistas se deslocam para fora de seu local de residência, os turista têm um tempo de permanência no destino limitado, o turismo compreende todas as etapas da viagem (partida, atividades realizadas na estada e retorno), não importa a motivação da viagem. O turismo inclui serviços e produtos criados para a satisfação das necessidades dos turistas.

Considera-se também, neste trabalho, que o Turismo é um sistema (OMT, 2001; Burns, 2002; Beni, 1998), sendo, dessa forma, "um conjunto complexo de inter-relações de diferentes fatores que devem ser considerados conjuntamente sob uma ótica sistemática, ou seja, um conjunto de elementos inter-relacionados que evoluem de forma dinâmica" (OMT, 2001, p. 39).

Dentro das relações estabelecidas no fenômeno turístico estão presentes a demanda, a oferta, o espaço geográfico e os operadores de mercado. A demanda consiste em um conjunto de consumidores ou consumidores em potencial de bens e serviços turísticos; a oferta em um conjunto de produtos, serviços e organizações envolvidas ativamente na experiência turística; o espaço geográfico é o local onde se estabelecem as relações entre demanda e oferta e; os operadores de mercado compreendem as empresas e organismos que facilitam as inter-relações entre oferta e demanda. São as agências de viagens, companhias aéreas, órgãos públicos e privados que trabalham na organização e promoção do turismo (OMT, 2001).

Não existe uma unanimidade para a definição de turismo (existem quase cem), conforme Barretto (2007). O que se pretende neste estudo é uma aproximação do seu objeto com o fenômeno, a fim de sua melhor compreensão. Van Harssel apud Burns (2002, p. 42) sustenta que essa dificuldade se dá "em parte devido à complexidade da atividade turística e, em parte, porque diferentes interesses estão envolvidos com aspectos diversos da atividade turística".

A maioria das definições está relacionada apenas do ponto de vista capitalista, em que a atividade turística representa fonte de lucros, não considerando aspectos naturais, sociais e culturais. Considerar o turismo apenas com o enfoque econômico, é correr o risco de o fenômeno ser prejudicial às comunidades onde ele pretende se desenvolver. Afinal, como postula Ansarah (2010, p. 68), "o turismo tem 
um importante papel no desenvolvimento, na educação e formação social do indivíduo". Ou, ainda, o que referendam Cerdan e Ramos (2010), ao afirmarem que o produto turístico tem que ser desenvolvido com qualidade para os turistas, porém "é preciso pensar em bem estar e melhoria das condições de vida da população local como um compromisso social, porque há uma relação íntima entre qualidade do produto turístico e qualidade de vida da população" (CERDAN E RAMOS, 2010, p. 13).

Felizmente, o turismo contemporâneo vem trazendo novos enfoques e sendo analisado como prática social. Nessa perspectiva, Moesch (2002) postula que o epicentro do fenômeno social é de caráter humano, pois são os homens que se deslocam, e não as mercadorias.

Para Gastal (2005), o turismo é um fenômeno social, cultural e econômico muito complexo. Ela sustenta que falar em turismo significa fazer referência àquelas pessoas que saem de suas rotinas espaciais e temporais por um período de tempo determinado: o cidadão que sai em férias, os netos que visitam os avós, o executivo que viaja a negócios. Gastal (2007, p. 11) postulou ainda que "o turismo é um campo de práticas histórico-sociais que pressupõem o deslocamento dos sujeitos em tempos e espaços diferentes daqueles dos seus cotidianos. É um deslocamento coberto de subjetividades."

Moesch (2004) afirma que "o turismo é um fenômeno dinâmico, real postulado no cotidiano de milhões de sujeitos consumidores e produtores". A autora defende a definição de Turismo como construto, e seu objeto parte do paradigma da complexidade (alicerçada nos estudos de Morin), em que esse fenômeno é compreendido como uma prática social, ou melhor, um campo de práticas históricosociais, que pressupõem o deslocamento dos sujeitos, em tempos e espaços produzidos de forma objetiva, possibilitador de afastamentos simbólicos do cotidiano, coberto de subjetividades, portanto explicitadores de uma nova estética diante da busca do prazer. Essa autora infere ainda que:

O turismo é uma combinação complexa de inter-relacionamentos entre produção e serviços, em cuja composição integram-se uma prática social com base cultural, com herança histórica, a um meio ambiente diverso, cartografia natural, relações sociais de hospitalidade, troca de informações interculturais. O somatório desta dinâmica sociocultural gera um fenômeno recheado de objetividade/subjetividade, consumido por milhões de pessoas, como síntese: o produto turístico. 
O turismo, enquanto prática social, pressupõe o sujeito (turista) em harmonia com a comunidade receptora. Essa comunhão deve ser rica em experiência para ambos, de modo que é imperativo que aqueles que viajam devem afetar o mínimo dos espaços percorridos, por outro lado, torna-se fundamental para os que recebem, saber acolher, não com subserviência, mas com orgulho e conhecimento de seu papel enquanto morador hospitaleiro (GASTAL e MOESCH, 2007),

Após a conceituação do que é turismo, buscar-se-á entender o significado da expressão Turista Cidadão, expressão esta que já vem sendo utilizada em alguns Estados e no Distrito Federal.

Turista Cidadão é uma expressão que vem sendo utilizada para designar aquele morador de uma localidade que é consciente de seus direitos, deveres e obrigações referentes ao fenômeno turístico, contribuindo de forma positiva para a construção de uma cidadania nacional e planetária.

A perspectiva do Turista Cidadão se aproxima da definição de turista clássico orientada pela OMT e MTur, no sentido do deslocamento, sendo que o turista cidadão é o próprio morador da cidade, que consegue sair da sua rotina, fazendo o uso do estranhamento dos espaços públicos ou particulares. Esse morador descobre novas oportunidades de lazer e entretenimento. $O$ deslocamento acontece dentro de seu próprio território. Quantas vezes as pessoas passam a caminho da escola, do trabalho ou, por tantos outros motivos, pela frente de um prédio histórico e nunca haviam reparado no detalhe de algum azulejo português, ou de uma particularidade na arquitetura, ou ainda, ao adentrarem uma igreja tiveram a informação sobre alguma imagem ou tela que compõem seu acervo religioso? Nesse sentido, Abreu (2012, p. 3) destaca que "a apropriação de um morador em relação a sua cidade está muito ligada ao desenvolvimento da cidadania no indivíduo".

A cidadania é entendida neste estudo como um conceito que articula outros (direitos, participação, políticas públicas, sociedade civil, educação e o turismo), portanto um conceito-rede (MEKSENAS, 2002). Assim como a educação, a cidadania não nos é dada, mas sim conquistada à luz de muitas lutas sociais por direitos civis (são aqueles fundamentais à vida, à liberdade, à propriedade, à igualdade perante a lei), e, conforme Carvalho (2002, p. 9), "se desdobram na garantia de ir e vir, de escolher o trabalho, de manifestar o pensamento, de organizar-se, de ter respeitada a inviabilidade do lar e da correspondência [...], de 
não ser condenado sem processo legal regular"; direitos políticos (postulam a participação do cidadão no governo da sociedade, organização de partidos, votar e ser votado, quase sempre quando se fala em direitos políticos, faz-se referência ao direito do voto. Os direitos políticos têm nos partidos políticos sua instância principal e um parlamento livre e representativo); e direitos sociais (os direitos sociais devem garantir a participação na riqueza coletiva do país, a saber: direito à educação, ao trabalho, ao salário justo, à saúde, à aposentadoria). Sobre os direitos sociais, Carvalho (2002, p. 10) infere que "eles permitem às sociedades politicamente organizadas reduzir os excessos de desigualdade produzidos pelo capitalismo e garantir um mínimo de bem-estar para todos". Todos esses direitos são assegurados pela Constituição Federal de 1998, considerada cidadã. Nessa perspectiva, Carvalho (2002) ressalta que os direitos civis têm na liberdade individual seu pressuposto máximo, os direitos políticos têm, em sua essência, a ideia de autogoverno, e os direitos sociais têm como premissa a justiça social. Para que ocorra a cidadania plena (talvez uma utopia), é necessário que se entrelace liberdade, participação e equidade para todos. Dessa forma, Carvalho (2002, p. 9) considera que "o cidadão pleno seria aquele que fosse titular dos três direitos, cidadãos incompletos seriam os que possuíssem apenas alguns direitos, os que não se beneficiassem de nenhum direito seriam não-cidadãos".

Na obra Cidadania no Brasil: o longo caminho, José Murilo de Carvalho (2002) apresenta importante contribuição para os estudos sobre a cidadania no Brasil, desde o período colonial até o início do século XXI.

Carvalho (2002) ressalta que o fenômeno da cidadania no Brasil é complexo e historicamente definido. Ele não oferece uma receita de cidadania, mas apresenta um aporte teórico para que cada leitor consiga desenvolver visão própria do assunto. Vejamos alguns pontos: no Brasil, ao contrário da Inglaterra, o processo da cidadania teve como ênfase maior os direitos sociais em detrimento aos direitos políticos e civis. Naquele país, a construção da cidadania teve início com os direitos civis, no século XVIII. No século XIX, vieram os direitos políticos e no século $X X$ os direitos sociais. Para Marshall apud Carvalho (2002), a sequência não é apenas cronológica, mas também lógica. "Foi com base no exercício dos direitos civis, nas liberdades civis, que os ingleses reivindicaram o direito de votar, de participar do governo de seu país" (CARVALHO, 2002, p. 11). 
Para uma análise cronológica da cidadania no Brasil, faz-se necessário entender que a época da independência não havia cidadãos brasileiros, muito menos pátria brasileira, que o futuro país nasceu da conquista de povos seminômades, na idade da pedra polida e por europeus que dominavam uma tecnologia mais avançada, onde milhões de indígenas tiveram suas vidas ceifadas por guerras, doenças ou escravização, sendo essa última considerada o fator mais negativo para a construção da cidadania. Outro fator que deve ser considerado é o comercial, pois a colonização foi um negócio do governo colonial com particulares.

Outro fato que merece destaque na construção democrática do Brasil, na época colonial, é o descaso pela educação primária. Em princípio, eram os jesuítas que se encarregavam de exercê-la, porém com a expulsão desses religiosos, em 1759, o governo se incumbiu de forma inadequada. Não existem dados sobre a alfabetização no final do período colonial (CARVALHO, 2002). Em relação ao ensino superior, Portugal não permitia a criação de universidades em sua colônia, situação oposta verificada na parte colonizada pela Espanha onde havia, no final do período colonial, 23 universidades e, aproximadamente, 150 mil pessoas foram graduadas. Ensino superior no Brasil só foi possível após a chegada da Corte (1808). Os brasileiros que quisessem ingressar em universidades teriam que viajar a Portugal e, quase sempre, estudavam em Coimbra. Calcula-se que, entre 1772 e 18772 , estudaram em Coimbra cerca de 1242 brasileiros, "comparado com os 150 mil da colônia espanhola, o número é ridículo” (CARVALHO, 2002, p. 23). O teórico acrescenta ainda, que, na época colonial, "os direitos civis beneficiavam a poucos, os direitos políticos a pouquíssimos, os direitos sociais ainda não se falava". (CARVALHO, 2002, p. 24). Ao que consta, a principal característica da independência brasileira foi a negociação entre a elite nacional, a Coroa Portuguesa e a Inglaterra.

A Constituição outorgada de 1824 foi o início dos direitos políticos no Brasil e regeu o país até o fim da Monarquia. Por ela, ficou estabelecido quem poderia votar e ser votado, homens com 25 anos ou mais estavam aptos ao voto, desde que tivessem renda mínima de 100 mil réis. Mulheres e escravos não tinham o direito de votar, aliás os escravos não eram considerados cidadãos.

Para Carvalho (2002), o legado colonial pesou muito para a construção da cidadania no Brasil, pois deixou como herança a escravidão que negava a condição humana do escravo, herdou a grande propriedade rural (fator que ainda hoje exerce 
seu poder em algumas áreas no país) e, por fim, um estado comprometido com o poder privado. As consequências da escravidão podem ser observadas ainda hoje, pois "essa população ocupa posição inferior em todos os indicadores de qualidade de vida. É a parcela menos educada da população, com empregos menos qualificados, os menores salários, os piores índices de ascensão social" (CARVALHO, 2002, p. 52).

Ao que tudo indica, até 1930 não havia no Brasil povo organizado politicamente, muito menos um sentimento nacional fortificado. Dessa forma, afirma Carvalho (2002, p. 83): "o povo não tinha lugar no sistema político, seja no Império, seja na República. O Brasil era ainda para ele uma realidade abstrata. Aos grandes acontecimentos políticos nacionais, ele assistia [...] como curioso, desconfiado, temeroso".

Dando um salto cronológico, a primeira experiência democrática no Brasil veio com a Constituição de 1946, que garantiu o voto a todos os cidadãos homens e mulheres com mais de 18 anos, obrigatório, secreto e direto. Entretanto, o voto dos analfabetos e soldados era proibido. Essa legislação não sofreu alterações até 1964.

Após experimentar a democracia incipiente, o Brasil volta a sentir um período conturbado de sua história com os governos militares, que Carvalho (2002) divide em três fases. A primeira, 1964 a 1968, governada pelo general Castelo Branco. Teve como características a repressão, combate à inflação, queda do salário mínimo e pouco crescimento. A segunda fase, que vai de 1968 a 1974, e que foram os piores anos da história do Brasil no que concerne aos direitos civis e políticos. Era o governo do então general Garrastazu Médici. A terceira fase tem início em 1974, sob o governo do general Ernesto Geisel, período em que as leis de repressão vão sendo, aos poucos, revogadas. Esse ciclo termina em 1985, com a eleição indireta de Tancredo Neves.

A chamada Ditadura Militar foi uma época sombria na história mais recente do Brasil. Através dos Atos institucionais, os direitos civis e políticos foram duramente atingidos. Os mais perversos foram o Al-1, Al-2 e o Al-5. Por esses mecanismos, foram cassados direitos políticos pelo período de dez anos de muitos líderes políticos, sindicais, intelectuais e militares. Houve a aposentadoria forçada de funcionários públicos civis e militares. Órgãos sofreram intervenções e foram fechados, como exemplo, a União Nacional dos Estudantes (UNE). Através do Al-2 estabeleceu-se um sistema de dois partidos políticos, aumentou consideravelmente 
o poder do presidente, concedendo-lhe plenos poderes para dissolver o parlamento, intervir nos estados, decretar estado de sítio, entre outros. O Al-5 foi o mais truculento de todos e o que mais atingiu os direitos políticos e civis. O congresso foi fechado, o general Costa e Silva passou a governar ditatorialmente. Em 1969, após Costa e Silva ter sofrido um infarto, assume a presidência do país o general Garrastazu Médici, em que as medidas repressivas têm seu ápice. Houve a introdução da pena de morte por fuzilamento, sendo que esse mecanismo havia sido abolido após a proclamação da República, dessa forma, um retrocesso para a democracia do país.

No início de 1970, foi decretada a censura prévia em jornais, livros e outros meios de comunicação. Na prática, toda e qualquer publicação deveria passar pelo crivo do governo. O governo ditava instruções de assuntos proibidos e o nome de pessoas que não poderia ser mencionados.

A situação era tão extrema que Carvalho (2002, p. 164) afirma que "a integridade física era violada pela tortura nos cárceres do governo, o próprio direito à vida era desrespeitado".

Para Carvalho (2002), os governos militares, no que tange à cidadania, mantiveram o direito do voto em consonância com "o esvaziamento de seu sentido e a expansão dos direitos sociais em momentos de restrição de direitos civis e políticos" (CARVALHO, 2002, p.172).

Após os governos militares, o episódio que merece ser destacado na década de 80 é a mobilização pelas eleições diretas, conhecida por "Diretas Já". Considerase a maior manifestação popular da história do país, haja vista ter atingido milhares de pessoas nas capitais e nas maiores cidades do Brasil. As pessoas saíram às ruas para pedir um pleito direto como exercício de democracia e consequentemente a cidadania. Para Carvalho (2002, p. 193), "pode-se dizer que o movimento pelas diretas serviu de aprendizado para a campanha posterior em favor do impedimento de Fernando Collor, outra importante e inédita demonstração de iniciativa cidadã". O teórico afirma ainda que o movimento "deu aos cidadãos a sensação inédita de que podiam exercer algum controle sobre os governantes" (p. 205).

A Constituição de 1988 foi a que mais ampliou os direitos sociais no Brasil. Para Carvalho (2002, p. 206), 
mais caiu de $25,4 \%$ em 1980 para $14,7 \%$ em 1996. A escolarização da população de sete a 14 anos subiu de $80 \%$ em 1980 para $97 \%$ em 2000

Apesar de todo o avanço conquistado na área educacional, as grandes desigualdades sociais são hoje o que existe de pior para a cidadania em nosso país. Há uma grande desigualdade entre as regiões, o sul e o sudeste são as ditas "regiões ricas e prósperas", em detrimento da região norte e nordeste onde tudo "parece atrasado". A diferença racial também é fator de extrema desigualdade no Brasil. Os negros são alijados na sociedade brasileira desde a época da colônia. Existe no país uma minoria que goza de todas as regalias possíveis em detrimento de uma maioria pobre e muitas vezes miserável.

Conforme Carvalho (2002), ainda hoje no Brasil os direitos que mais apresentam deficiências em termos de seu conhecimento, extensão e garantias são os civis, e a educação para a cidadania é um caminho importante a ser percorrido nesse processo.

A construção da cidadania no Brasil é uma realidade no cotidiano de homens e mulheres que acreditam que outro cenário é possível, onde as diferenças na distribuição das riquezas produzidas no país podem ser compartilhadas, onde é possível a equidade entre brancos, negros, amarelos e índios.

Segundo Carvalho (2002), a diferença na sequência em que foram conquistados os direitos entre o Brasil e a Inglaterra trouxe para o país a supremacia do Estado. Nesse sentido:

Se há algo importante a fazer em termos de consolidação democrática, é
reforçar a organização da sociedade para dar embasamento social ao
político, isto é, para democratizar o poder. A organização da sociedade não
precisa e não deve ser feita contra o estado em si. Ela deve ser feita contra o
estado clientelista, corporativo, colonizado (CARVALHO, p. 227).

Sobre os estudos de cidadania no Brasil recorreu-se a outro importante teórico, Gadotti (2010, p. 68), qual afirma que a:

Cidadania é essencialmente consciência de direitos e deveres e exercício da democracia: direitos civis, como segurança e locomoção; direitos sociais, como trabalho, salário justo, saúde, educação, habitação etc.; direitos políticos, como liberdade de expressão, de voto, de participação em partidos políticos e sindicatos, etc. Não há cidadania sem democracia.

Para Gadotti, cidadania está intrinsecamente relacionada à ideia de autonomia e democracia, onde "cidadão é aquele que participa do governo; e só 
pode participar do governo - participar da tomada de decisões - quem tiver poder e tiver liberdade e autonomia para exercê-lo" (GADOTTI, 2012, p. 51).

Em Práticas de Cidadania Jaime Pinsky (2004) reúne importantes contribuições acerca de ações cidadãs defendidas, praticadas e conquistadas por homens e mulheres em diversos contextos sociais. A publicação tem como artigo inicial o relato do juiz federal José Renato Nalini que discute os caminhos para o acesso da população mais carente/humilde à justiça. As dificuldades encontradas são muitas e a maioria da população não consegue ter acesso ao juiz, por exemplo. O magistrado recorre a Hannah Arendt para situar o conceito técnico de cidadania para as ciências jurídicas, ao afirmar que "é o direito a ter direitos". Porém, "milhões de brasileiros desconhecem os seus direitos, já se acostumaram com a subsistência indigna, à margem da vida, desprovidos de todos os bens, principalmente desprovidos de esperança, de projeto, de qualquer perspectiva de inclusão" (NALINI, 2004, p. 14).

Nalini explica que "a pobreza dificulta a comunicação”, o acesso ao judiciário só acontece via advogado e para se chegar a ele o caminho é burocrático e sofrido. O juiz infere que as pessoas simples não se sentem a vontade no ambiente forense, pois o mesmo é solene, assustador e insólito, outro obstáculo é a linguagem ininteligível, técnica e vernacular. Carvalho (2002, p. 214) endossa essa afirmação de Nalini ao destacar que "o acesso à justiça é limitado à pequena parcela da população. A maioria ou desconhece seus direitos, ou, se os conhece, não tem condições de os fazer valer", ou ainda "os custos dos serviços de um bom advogado estão além da capacidade da grande maioria da população. Embora está na constituição que o Estado tem o dever de prestar assistência gratuita aos pobres".

Com o aporte na Constituição de 1988, o magistrado postula que a reforma do poder judiciário poderá ser uma "luz no fim do túnel" para as questões de aceso do cidadão comum à justiça. A constituinte, para Nalini, fez a sua parte, indicou os caminhos. Ao término do artigo, Nalini (2004, p. 19) infere que "a cada um de nós abriu-se o espaço para concretizar as promessas do constituinte ou para ocupar a passiva letargia de quem observa a história e não se sente dono de seu destino". A escolha é individual.

Outra contribuição às ações de cidadania vem do artigo de Duilio Duka de Souza, intitulado Combate ao Racismo: compromissos e ações propositivas. No referido texto, o autor destaca a ação de entidades que combatem o racismo na 
escola como o Sindicato dos Professores do Ensino Oficial do Estado de São Paulo (APEOESP) e a Confederação Nacional dos Trabalhadores em Educação (CNTE). Entre outras bandeiras, a CNTE defende uma educação pública e de qualidade para todos e todas, a fim da plena cidadania, ou seja, "luta pela erradicação do racismo, da discriminação racial, da xenofobia e de formas conexas de intolerância no país". (SOUZA, 2004, p. 41). Souza dialoga com Freire (2011), ao postular que "os sujeitos são construídos no mesmo ambiente em que vivem, convivem e produzem". O referido professor tem uma visão bem ampla do que é ser cidadão ao afirmar que:

Ser cidadão, ou cidadã, é poder ter condições de romper barreiras da ignorância moral, espiritual e intelectual. É ter a capacidade de pensar e refletir a vida política, econômica, cultural e social em que vive, local e globalmente. Ser capaz de adquirir, e ter sempre presente em si, uma consciência histórica, democrática e internacional, cuja plataforma seja o direito de igualdade e oportunidade, a tolerância, a solidariedade, o respeito, a paz e a justiça.

Dessa forma, a Escola Frei Ambrósio desenvolve um Projeto de cidadania por nome Sol Cidadão Legal. Este Projeto deu tão certo na Escola que está se expandindo em 2015 para outras escolas no município de Santarém. Em 2014, foi vencedor, em primeiro lugar, na categoria escolas em um concurso nacional denominado Prêmio Nacional de Educação Fiscal ${ }^{13}$, como explica uma das coordenadoras do projeto:

O prêmio se chama Prêmio Nacional de Educação Fiscal né, primeiramente só pra situar, eu faço parte do grupo municipal de educação fiscal. A educação fiscal, ela veio justamente para trabalhar essa questão da formação cidadã né, ela é uma... É um plano nacional que se chama PNEF (Plano Nacional de Educação Fiscal), onde através da Internet, por exemplo, eles fazem a formação dos professores, e ai vai numa rede, regional, municipal, e nós somos na verdade disseminadores, fazemos cursos, somos preparados para que nós possamos tá trabalhando com os nossos alunos questões é que envolvem a administração pública né, o poder público como em si, impostos, para que os alunos possam conhecer os seus direitos, e então possam né tá lutando por eles, nós participamos do prêmio nacional já desde 2012, como o Projeto Sol Cidadão Legal onde uma das atividades é a prefeitura mirim. Em 2012, de 200 projetos inscritos no Brasil, onde nós concorremos com prefeituras, com, é... Universidades escolas, nós ficamos em quarto lugar, fomos para Brasília e ficamos em quarto, sendo que os três primeiros eram prefeituras, então, de novo já, já havíamos ficado bem na época né. $E$ em 2014 agora, nós nos inscrevemos e de... Agora foi por é, entidade, foram duas categorias: a categoria universidades e prefeituras e a categoria escolas, então na categoria escolas nós ficamos em primeiro lugar no Prêmio Nacional de Educação Fiscal, e participar dessa premiação é uma

\footnotetext{
${ }^{13}$ Para maiores informações sobre o Prêmio Nacional de Educação Fiscal consultar o site do evento: http://www.premioeducacaofiscal.com.br
} 
importância imensa né, primeiro enquanto professor, porque a gente acredita que enquanto ser professor né, na verdade, se fala muito em mudança no ensino médio, se fala muito em mudanças no ensino fundamental, se fala em aumentar as estruturas das escolas, se aumentou recursos paras as escolas através do Programa Ensino Médio Inovador - PROEMI, através do Mais Educação, mas nós enquanto professores né, a coisa fica solta, não há formação de professores, não há uma formação continuada, não há um incentivo pra que nós possamos tá estudando, não há um incentivo pra que nós possamos está melhorando as nossas aulas, enfim...E ai enquanto professor tu idealizar um projeto né, sair da tua sala de aula, ir pra escola, depois esse projeto tomar uma dimensão municipal, ter o reconhecimento de outros colegas, e enfim...Ter um conhecimento nacional né, ser o primeiro lugar a nível nacional num total de 200 projetos, tem uma significância imensa pra nós enquanto professores, porque é saber que pô vale a pena de alguma forma. Enquanto escola, mais ainda, porque é a percepção de que tá dando certo né, de que na Escola Frei Ambrósio tá se fazendo um trabalho em prol da formação desses nossos alunos né... $E$ melhor, enquanto escola sermos avaliados por técnicos né, sermos avaliados por gente que faz a educação fiscal lá em cima e que são analistas tributários né, receita estadual, receita federal, enfim, que é a Federação Brasileira de Associação de Fiscais de Tributos Estaduais - FEBRAFITE, sermos avaliados e esse mundo ai dizer assim: eles são os melhores né, eles são os primeiros, e numa concorrência assim muito... Sabe, muito forte porque eles vieram na escola, eles vieram fiscalizar, além de toda comunicação, nós passamos por todo um critério, porque o prêmio, ele começa em março pra você ter uma ideia e o resultado só sai em outubro, então durante esse processo todinho ai as escolas que se candidatam, elas são avaliadas, então assim... Enquanto Escola Frei Ambrósio, é de suma importância né, não só trabalha a autoestima nossa enquanto professor, enquanto alunos né, nos coloca num ranking, e é muito legal sabe tá por ai, e dizerem assim: puxa, parabéns a Escola Frei Ambrósio, é muito legal... É, tudo quanto que é evento que nós vamos ou que há por ai, enquanto escola, a escola sempre é referenciada, sempre parabenizada, então assim, enquanto escola a gente ganha, sabe, nada financeiro, nós ganhamos quinze mil reais para implantar no projeto né, mas é mais do que isso, é saber que mesmo com os nossos problemas, ele vem dando certo né, e enquanto cidade, porque a nível nacional, pensa, nós concorremos com São Paulo, Brasília, o Rio, sabe, projetos belíssimos, que são apresentados e foi Santarém do Pará, pra você ter uma ideia o Amazonas, ele inscreveu 51 projetos, nenhuma das escolas ficou nem entre os 10 melhores, eu adoro dizer isso, inclusive. O Pará foram seis projetos inscritos e foi Santarém do Pará que ganhou, então o projeto, ele tem uma significância imensa né pra todos esses segmentos, mas o principal, eu acho, é pro nosso aluno né, que aqui é prefeito, que aqui é vice-prefeito, que aqui é vereador mirim né, que aqui faz parte do teatro, que usa o teatro pra falar de corrupção né, que usa o teatro pra falar...Que, que... Corrupção é tomar o lugar do outro na fila, é não devolver um lápis, sabe, então assim, brincando eles fazem isso, então eu acho que o melhor ganho é esse, é ele poder ser reconhecido. Tu não imaginas o que foi tá em Brasília eu e o Geovane, que é um vereador mirim e tá com quase 100 no whatsapp, sabe, parece que eles estavam lá né, é, eles o tempo todo na festa, vamo, vamos ser primeiro e tal, até a hora da festa e nós festejando junto, eles no whatsapp aqui em Santarém e nós estávamos em Brasília, então tu não imagina o quanto isso é maravilhoso né pra nós enquanto professores e, os reflexos nos já vemos neles né, isso é fundamental, os meninos são altamente participativos na escola, não é à toa que eles hoje trabalham na xerox, não é à toa que eles são procurados para resolver os problemas da escola pelos próprios alunos, agora mesmo o prefeito acabou de me dizer ali que tem um aluno nosso que foi embora para Manaus e ele veio me dizer: professora a escola toda tá me procurando para saber do fulano, porque que ele foi, então assim: ele acaba sendo uma referência né, então pra gente é maravilhoso participar do Prêmio Nacional de 
Educação Fiscal, além de nos deixar muito bem na história, é como eu tô falando: a gente pode abrir a boca nós somos o primeiro lugar né não é um prêmiozinho qualquer, é um prêmio que, que requereu é, objetividade, técnica né e, que dentro da programação dele... Um cronograma, sabe, método de avaliação, então é todo um critério que nós obedecemos, então é híper importante pra nós.

Ao se fazer uma análise da fala da professora, percebe-se como é importante para alunos e professores estarem em sintonia, saírem de sala de aula e participarem de projetos que construam novos olhares, novas possibilidades no universo escolar. A cidadania se constrói também a partir do conhecimento dos direitos e do fazer valer deles.

Através dos relatos, percebe-se ainda, que a construção da cidadania é diária e depende muito de uma educação igualitária para todos e todas onde a informação é um imperativo essencial no processo. Não se pode pensar em cidadania sem o direito ao acesso, o direito de ir e vir ou a liberdade de pensamento, sem ser sujeito de sua história.

Conforme Manzini-Covre apud Gastal e Moesch:

A cidadania e seu exercício não se restringem ao direito ao voto. O pleno exercício da cidadania supõe direitos civis, direitos políticos (participação no poder por meio do direito de associação, de livre expressão e de práticas políticas), direitos sociais (regulação do trabalho, aposentadoria, alimentação, habitação, saúde e educação), direitos culturais. Seria, ainda, uma estratégia de luta para uma nova sociedade. A cidadania envolveria [...] atender, cada vez mais, ao bem estar da maior parte da população do planeta. Tal ação social crítica diz respeito ao exercício da cidadania como processo inventivo de cada um e de todos, de forma que possamos ter as mesmas condições comuns, regidas por normas legais de que possamos fazer uso igualmente. Avançamos daí para maior democracia (GASTAL E MOESCH, 2007, p. 3132).

Assim, o sujeito histórico consciente de sua condição passa a usufruir dos espaços públicos construindo uma relação de pertencimento e identificação e não mais precisa deslocar-se de seu local de origem para outro distante, mas apropriarse daquilo que é seu, sua cidade. Pois, "uma cidade só é boa para o turista se for boa para o seu cidadão" (TANIGUCHI apud GASTAL E MOESCH 2007, p. 61).

O Turista Cidadão, conforme Moesch (2007, p. 65) é:

Aquele morador da localidade que vivencia práticas sociais, no seu tempo rotineiro, dentro de sua cidade, de forma não rotineira, onde é provado em relação à cidade. Turista cidadão é aquele que resgata a cultura da sua cidade, fazendo uso do estranhamento da mesma. Este estranhamento inicia no momento em que o indivíduo descobre no espaço cotidiano, outras culturas, outras formas étnicas e outras oportunidades de lazer e entretenimento. Quando se encontra na situação de turista cidadão, este sujeito aprende a utilizar os espaços ambientais, culturais, históricos, 
comerciais e de entretenimento com uma percepção diferenciada do seu cotidiano.

As experiências de cidades como Porto Alegre, Curitiba, Fortaleza, Camboriú e Brasília mostram como essa prática do turista cidadão já é uma realidade no Brasil, porém de forma bem embrionária.

A experiência do Turista Cidadão em Curitiba constitui-se em um dos exemplos referenciais dessa prática. O então prefeito, à época (2003), Cássio Taniguchi declarou: "o planejamento voltado ao cidadão transformou pedreiras em parques e fez do sistema de transporte um exemplo para o Brasil e o mundo" (TANIGUCHI apud GASTAL e MOESCH, 2007, p. 61). Para ele, o curitibano satisfeito com sua cidade a trataria como extensão de sua casa.

Em Brasília, outra iniciativa acerca do Turista Cidadão é o Turismo Cidadão. A inciativa tem por objetivo disseminar a história da capital do país através da visitação aos pontos turísticos, como a Esplanada dos Ministérios, a Catedral Metropolitana (igreja de Nossa Senhora Aparecida), o Palácio do Itamaraty, entre outros. Nesse primeiro momento, para crianças, idosos e deficientes físicos.

A possibilidade da efetivação do Turismo Cidadão em Santarém ainda é uma construção idealizada, pois precisa ser debatida entre o poder público e a comunidade local. Porém, a escola Frei Ambrósio já trabalha a questão da cidadania com seus alunos há alguns anos e, desde 2012, vem desenvolvendo um projeto denominado Sol Cidadão Legal que trabalha especificamente com questões que envolvem a cidadania.

Sobre esse Projeto, um dos professores entrevistados - a coordenadora -, assim se manifestou:

Bem, eu pessoalmente coordeno o Projeto Sol Cidadão Legal né que é um projeto que realmente envolve a cidadania né, nós trabalhamos efetivamente isso. O Sol Cidadão Legal nós temos uma prefeitura mirim instalada na escola, eles recebem a capacitação em cidadania, em direitos e deveres do cidadão né que diz isso né, a questão do sistema tributário nacional, da aplicação dos recursos públicos, o controle social disso, da valorização do patrimônio material da escola a partir do princípio de que todos pagam impostos, da formação cidadã como um todo desses meninos, eles atuam dentro da câmara municipal, nós temos sessões mirins, nós enquanto Frei Ambrósio que instalamos isso na cidade, nós instalamos a primeira prefeitura mirim da cidade, nós temos o primeiro pleito mirim, esse projeto tá instalando mais sete prefeituras mirins porque é um resultado que deu certo, os vereadores da cidade estão constantemente com a prefeitura mirim nas sessões mirins dentro da escola né, então o Sol Cidadão Legal, ele faz esse trabalho que envolve a cidadania sim e a questão patrimonial [...] Dentro da escola tem dois anos completos do projeto Sol Cidadão e ele envolve a 
escola como um todo, elas (ações) são focadas em turmas, mas abrange a escola como um todo. Ele é um projeto que tem a parceria com a Receita Estadual que é o grupo municipal de educação fiscal, então de dentro dele está a Receita Estadual, a Receita Federal, a Secretaria de Finanças do Município, a Câmara de Vereadores né, e a APES que é a Associação dos Amigos do Projeto Sol.

Através da fala da professora pode-se aferir que a Escola Frei Ambrósio é um exemplo a ser seguido por outras instituições de ensino em Santarém, no Pará e em outros Estados do Brasil. É uma escola comprometida com o ensino baseado na participação do aluno no contexto da escola e sociedade, onde o aluno é instigado a refletir sobre sua condição de aluno/cidadão, na escola e fora dela.

Ao proporcionar ao aluno experiências educacionais, práticas aliadas à teoria, como é o exemplo da Prefeitura Mirim, a escola provoca no mesmo o despertar para questões que fazem parte do seu quotidiano como a cidadania e suas interfaces, problemas estruturais da escola, problemas políticos, culturais e sociais da cidade onde residem, dentre outros. O professor Ernani Maria Fiori no prefácio do livro Pedagogia do Oprimido, de Paulo Freire, ressalta que "conscientizar é politizar", logo, se os alunos estão inseridos em projetos dentro da escola sobre temas que os levem a reflexão e, consequentemente, à conscientização poderão constituir-se em cidadãos críticos e reflexivos. Nessa perspectiva Freire (2011, p. 75) destaca:

O meu papel no mundo não é só o de quem constata o que ocorre, mas também o de quem intervém como sujeito de ocorrências. Não sou apenas objeto da história, mas seu sujeito igualmente. No mundo da história, da cultura, da política, constato não para me adaptar, mas para mudar.

Observa-se também que a parceria da escola com o poder público através da Prefeitura de Santarém, Câmara de Vereadores, Receita Estadual e Federal é uma forma de construir algo novo que está dando certo e contribuindo para um ensino cidadão, uma educação diferenciada que permite ao aluno ser objeto e sujeito de sua história em uma relação dialética.

Apesar de todas as dificuldades enfrentadas pelos alunos e professores da Escola Frei Ambrósio, advindas do poder público - a não formação continuada, o não incentivo para os professores continuarem seus estudos, o não incentivo para que as aulas sejam melhor conduzidas (faltam equipamentos áudio visuais, laboratórios, livros, salas arejadas, quadro magnético, etc), ou seja, muito se conspira para um ensino de má qualidade -, a escola idealiza um projeto inovador, que estimula o debate sobre cidadania, cultura, Patrimônio, administração pública, 
corrupção, entre outros, ganhando dimensão municipal e nacional. É uma conquista muito importante e fomenta nos professores e alunos autoestima, e faz com que a escola seja referência e seus alunos construam sua cidadania. Nesses termos, Gadotti (2010, p. 63) infere: "a questão essencial da escola hoje refere-se à sua qualidade. $\mathrm{E}$ a qualidade está diretamente relacionada com pequenos projetos das próprias escolas que são muito mais eficazes na conquista dessa qualidade".

Pensar em Turismo Cidadão e consequentemente em Turista Cidadão para Santarém é acreditar que existe essa possibilidade sim, e que a escola Frei Ambrósio é precursora desse processo não só pelo Projeto Sol Cidadão Legal, mas também por outros projetos que são desenvolvidos pela escola que envolve alunos, professores e comunidade. $O$ fato de o aluno sair de sala de aula e visitar um museu ou uma igreja guiados pelo professor, dialogando com os atores que lá estão, obtendo novos conhecimentos, experimentando o estranhamento do novo, de um olhar diferenciado do costumeiro, já Ihe possibilita a chancela de Turista Cidadão.

A Educação Patrimonial poderá ser um meio na construção desse novo olhar dos alunos da Escola Frei Ambrósio, em que conforme Klamt e Soares (2007, p. 171) "o objeto cultural se torna um ponto de partida do processo de ensinoaprendizagem que capacita para conhecer, usar, desfrutar, recriar e transformar o patrimônio cultural".

A perspectiva de Educação Patrimonial na Escola Frei Ambrósio, do ponto de vista de alunos e professores, será abordada no capítulo seguinte, bem como, questões relacionadas à cidadania, Patrimônio e Turismo. 


\section{EDUCAÇÃO PATRIMONIAL NA ESCOLA ESTADUAL DE ENSINO FUNDAMENTAL E MÉDIO FREI AMBRÓSIO}

\section{1 objeto da pesquisa e suas interfaces}

O presente capítulo aborda a Educação Patrimonial na Escola Estadual de Ensino Fundamental e Médio Freio Ambrósio, através da análise de entrevistas feitas com professores e alunos da instituição, com vistas a apreender o entendimento que tais sujeitos têm das noções de Patrimônio Histórico Cultural e Educação Patrimonial; a relação que estabelecem entre essa noção e o Patrimônio da Cidade de Santarém e; a percepção que eles têm do Patrimônio local e sua História, no contexto de práticas pedagógicas que objetivam o exercício da cidadania e afirmação de identidades culturais locais, em face da globalização que tudo tenta homogeneizar.

Antes de tudo, para que possamos situar melhor o objeto desta pesquisa, fezse uma breve explanação sobre o contexto sócio-histórico e político pedagógico da Escola, para melhor entender as construções dos significados atribuídos ao Patrimônio Histórico Cultural da cidade, e as práticas pedagógicas que têm como fito a Educação Patrimonial como vetor de valoração e incentivo à cultura.

Fundada em 03 de maio de 1900, e primeiramente nominada Grupo Escolar de Santarém, a Escola Estadual de Ensino Fundamental e Médio Frei Ambrósio, como é chamada atualmente, é a mais antiga da cidade de Santarém (FONSECA, 1996).

Criada durante a gestão do governador Paes de Carvalho, constituiu-se no primeiro da categoria no interior, e o segundo da categoria no Estado do Pará. Entre 1900 e 1919 a Escola funcionou no antigo Solar do Barão de Santarém (Figura 04), depois passou a funcionar na Rua Siqueira Campos, espaço onde, atualmente, encontra-se a Escola Estadual de Ensino Médio Rodrigues dos Santos.

Em 1932, a Escola Frei Ambrósio tem novo endereço, agora situado na Rua Joaquim Braga, $\mathrm{n}^{\circ} 36$, no Centro de Santarém. O antigo Grupo Escolar funcionou durante 19 anos no Solar do Barão de Santarém, 13 anos onde está a atual Escola Rodrigues dos Santos e hoje tem prédio próprio. (FONSECA, 1996)

O nome da escola é uma homenagem a um ilustre sacerdote franciscano Ambrósio Philipsenburg - nascido em 01 de outubro de 1880, cidade de Essen, Alemanha, que contribuiu muito com a educação na cidade e pelo ensino religioso. 
O frei faleceu em 14 de março de 1936, quando estava em viagem religiosa entre os índios mundurucus.

O local atual onde está situada a Escola Frei Ambrósio fica em uma colina, lugar onde, outrora, era um Forte construído pelos portugueses no período colonial, que depois recebeu o nome de "Fortaleza dos Tapajós".

Com o intuito de combater os invasores, os portugueses construíram edificações, e o "Forte do Tapajós”, em 1697, foi uma delas. Para Guimarães e Silva (2012, p. 5), "os Fortes, além de servir para que Portugal controlasse as terras invadidas na região amazônica, prestavam-se como base de apoio a religiosos, a missões promovidas por esses e a colonos na busca por mão-de-obra nativa".

Reis (1979, p. 52) descreve assim o projeto da Fortaleza: "era em forma de quadrilátero com 48 metros de lado e um baluarte em cada vértice. No centro estava localizado um paiol, alojamento para a tropa e a cadeia. As muralhas de taipa e pilão possuíam seteiras para os mosquetões". Conforme Guimarães e Silva (2012, p. 5), "a Fortaleza serviu de moradia para os missionários e simbolizou para o contexto histórico a representação luso-portuguesa nas terras amazônicas".

Durante o século XVIII, a "Fortaleza dos Tapajós", por não contar com uma estrutura adequada começou a ruir e foi perdendo seu caráter militar. Em 1835, serviu de resistência pelos cabanos o que gerou grande polêmica pelas autoridades locais. Afinal, a Fortaleza fora erguida com outro intuito, e não para servir de aporte para movimentos populares contrários ao governo português na Amazônia. "Aos poucos a Fortaleza foi perdendo seu sentido militar e a falta de interesses dos representantes locais em preservá-la fez com que as ruínas de uma outrora Fortaleza não passassem de escombros" (GUIMARÃES E SILVA, 2012, p. 7).

Em 1867, houve uma última tentativa de recuperação da Fortaleza, quando o governador imperial enviou um capitão-engenheiro por nome Luiz Antônio de Sousa Pitanga para realizar o trabalho. Além disso, enviou seis canhões para serem colocados na fortificação.

Em 1948, depois de quase um século dos canhões ficarem esquecidos no leito da Rua Galdino Veloso, dois deles foram levados para a Praça do Centenário onde permanecem até hoje; dois encontram-se no Aeroporto de Santarém Maestro Wilson Fonseca; e dois estão no Campus Tapajós da Universidade Federal do Oeste do Pará (UFOPA). 
Acerca do descaso com a fortificação, Reis (1979, p. 122) assim relata: "dentro de poucos anos a fortificação, abandonada de vez, desfazia-se em escombros. Depois Ihes tiraram os canhões, precipitaram-nos pelas ladeiras da colina abaixo, para um terreno particular". Para Fonseca (1996, p. 28), "hoje, nem mais se vislumbra o que quer que seja do antigo Forte, que desapareceu por completo".

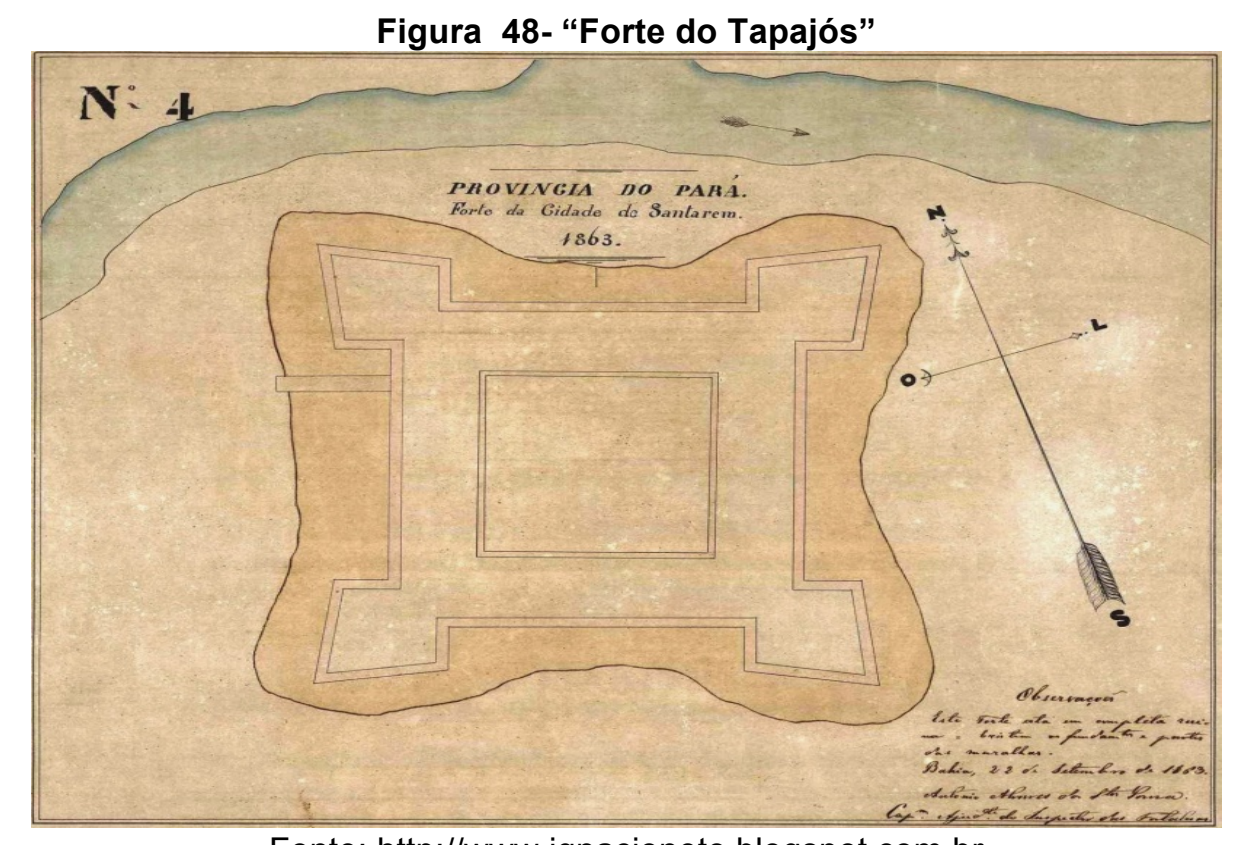

Fonte: http://www.ignacioneto.blogspot.com.br

Figura 49- Frente da cidade com a "Fortaleza do Tapajós" ao fundo

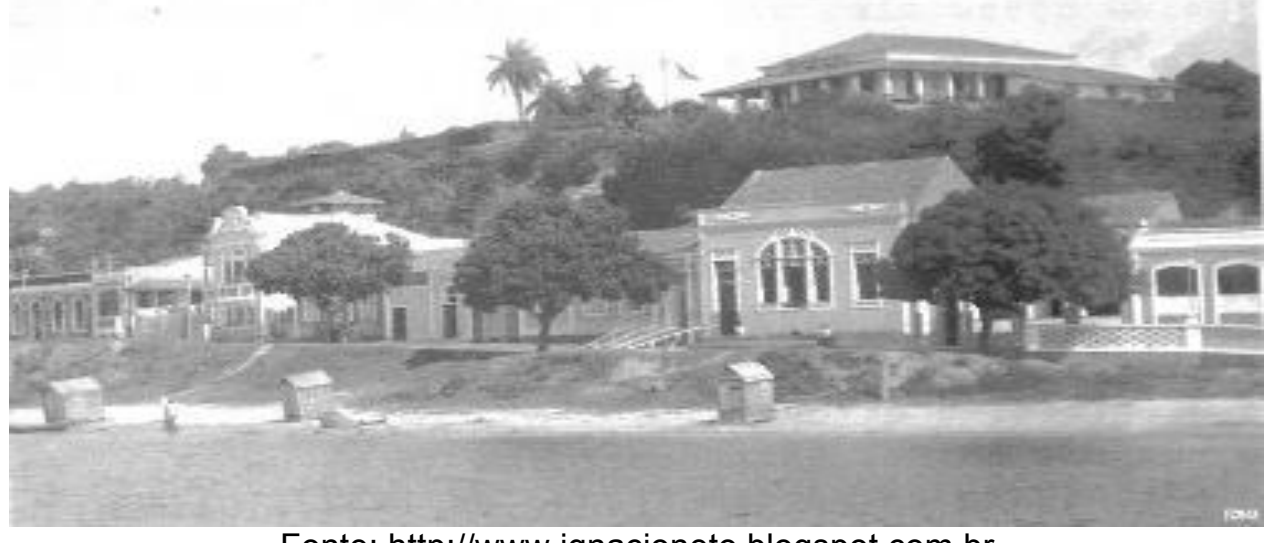

Fonte: http://www.ignacioneto.blogspot.com.br 


\section{Figura 50- Frente da cidade com a "Fortaleza do Tapajós" ao fundo I}

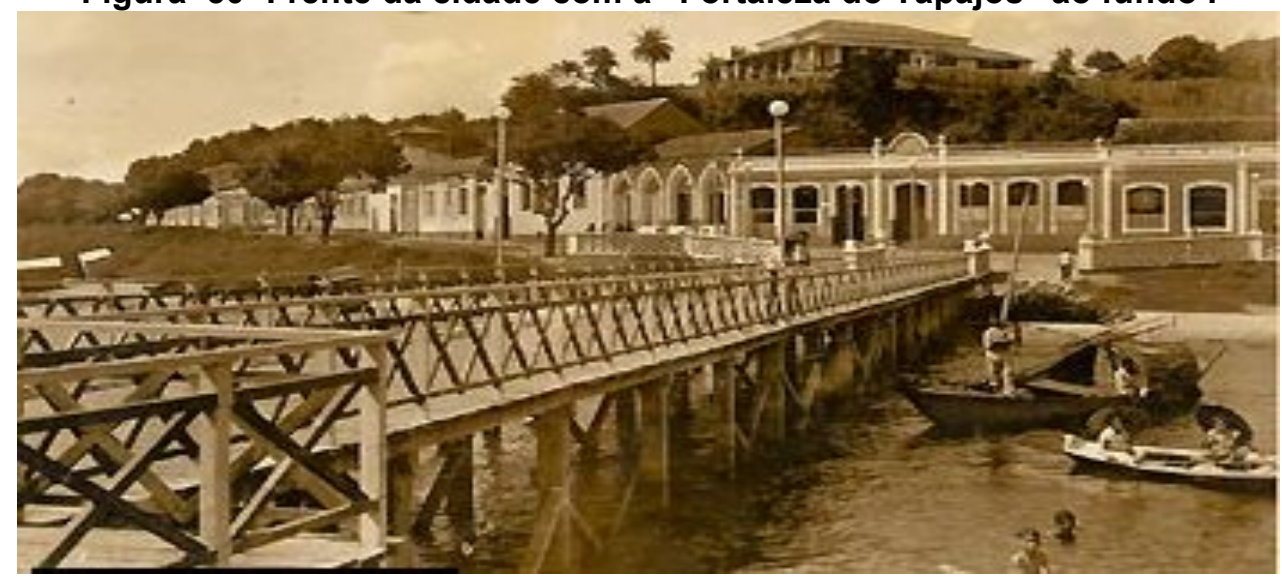

Fonte: http://www.ignacioneto.blogspot.com.br

Em 2006, a Prefeitura de Santarém, através da Secretaria Municipal de Turismo (SEMTUR), revitalizou a Praça Mirante do Tapajós que fica localizada na frente da Escola Frei Ambrósio, onde foram colocados quiosques de vendas de comidas típicas; um elevado em madeira de lei, que funciona como mirante e bancos. O espaço serve como ponto turístico da cidade, com vista privilegiada para o encontro das águas dos Rios Amazonas e Tapajós.

Figura 51- Praça do Mirante antes da revitalização

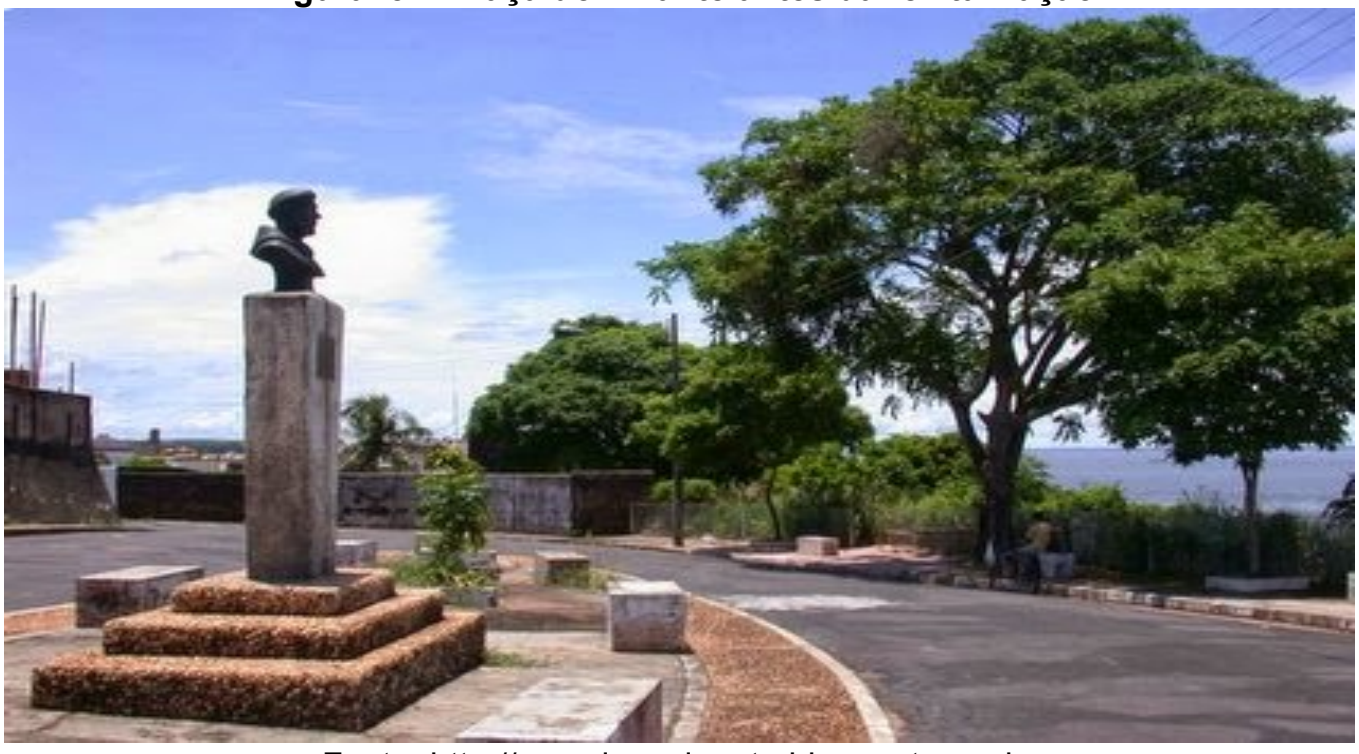

Fonte: http://www.ignacioneto.blogspot.com.br 
Figura 52 - Praça do Mirante na atualidade

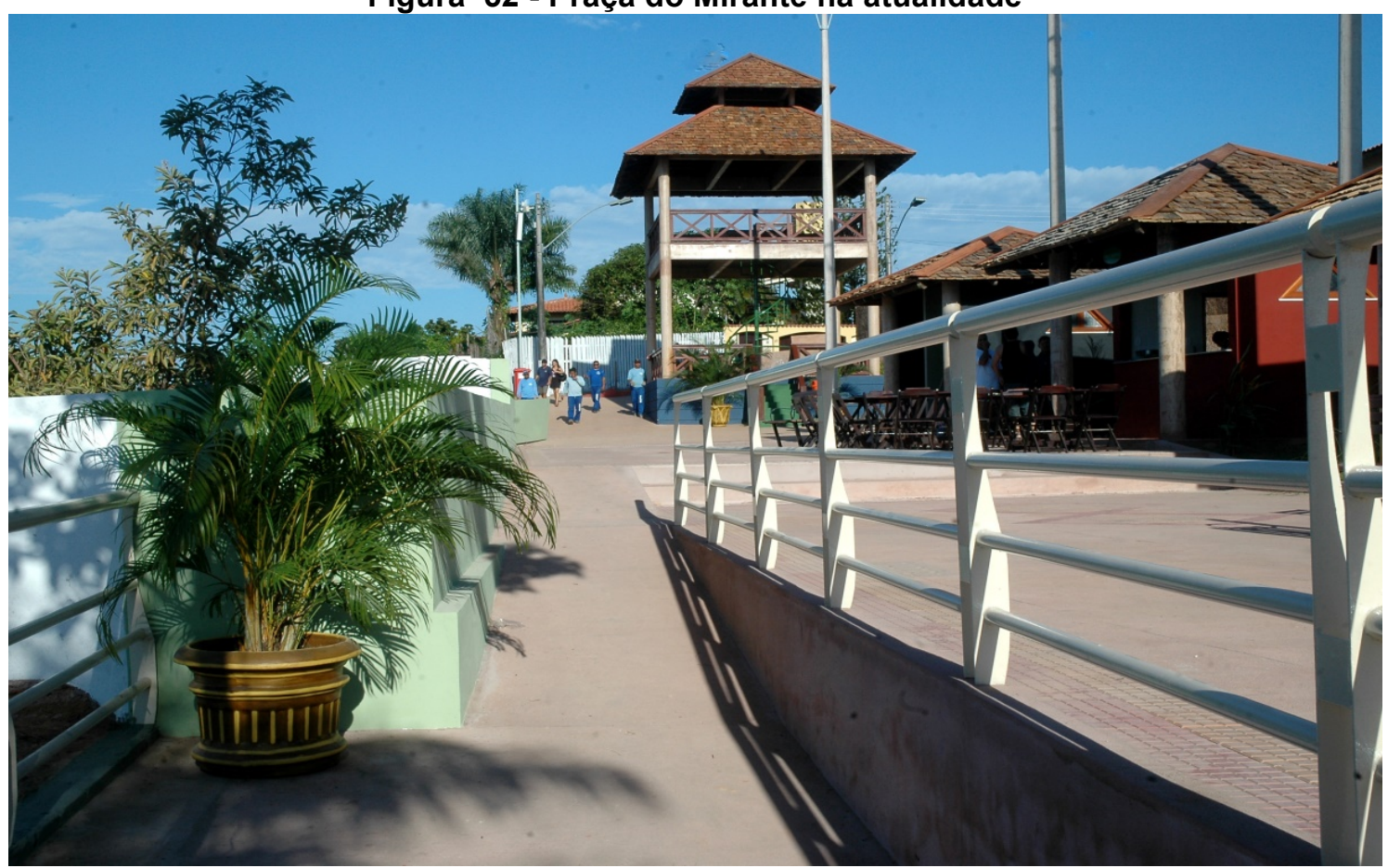

Fonte: Ronaldo Ferreira

Figura 53- Praça do Mirante na atualidade I

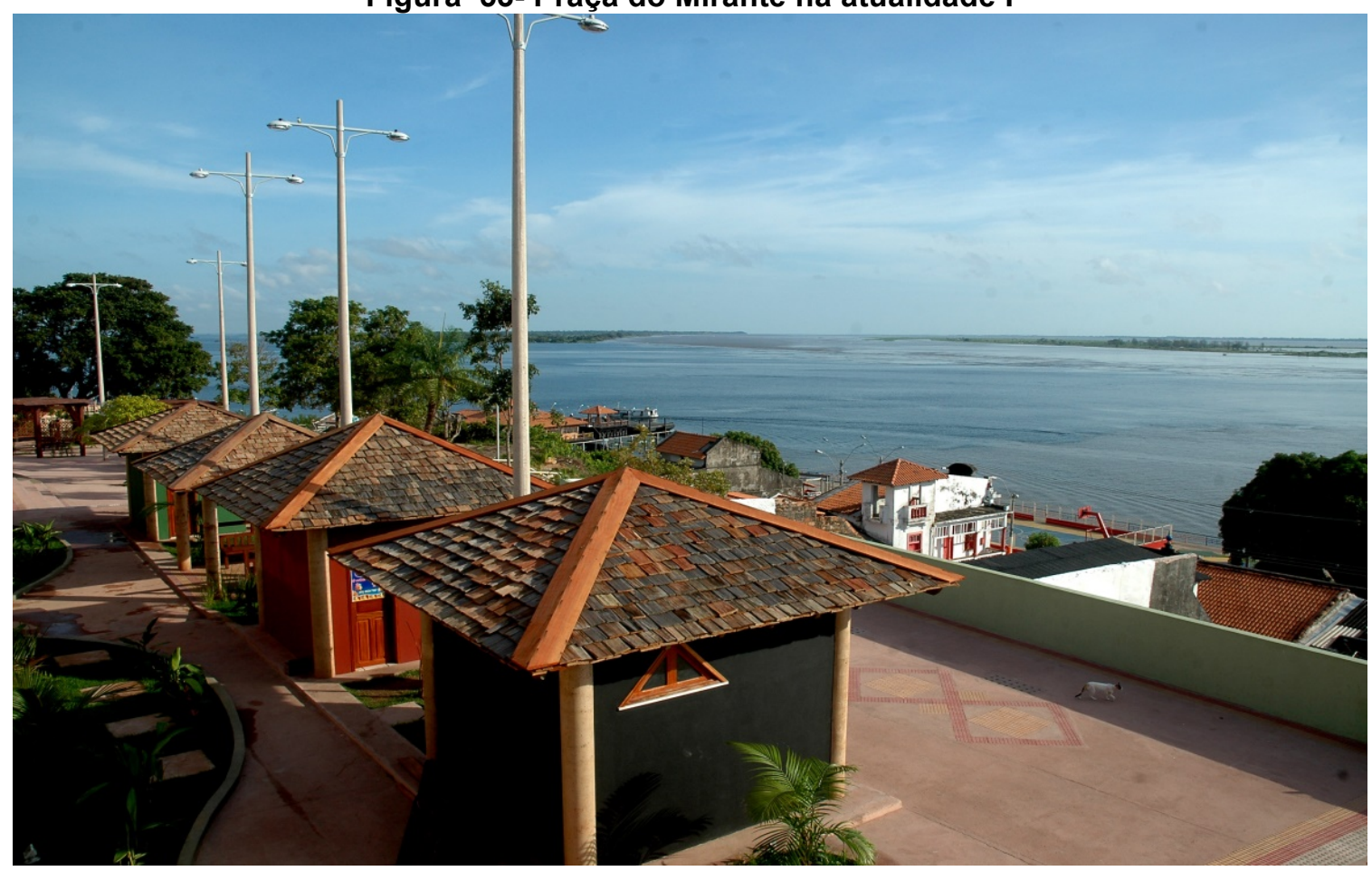

Fonte: Ronaldo Ferreira

A Escola Frei Ambrósio, atualmente, conta com 1.029 alunos distribuídos em três turnos: matutino, vespertino e noturno. 
Quanto aos níveis de ensino e modalidades de ensino, a Escola está assim composta: ensino fundamental, de $5^{\mathrm{a}}$ a $8^{\mathrm{a}}$ séries; ensino fundamental, $6^{\circ}$ e $7^{\circ}$ anos, em processo; ensino médio regular, $1^{\circ}, 2^{\circ}$ e $3^{\circ}$ anos e; Educação de Jovens e Adultos Médio.

No turno matutino, em 2014, havia doze turmas, quais sejam: três de ensino fundamental, de $7^{a}$ a $8^{a}$ séries $/ 6^{\circ}$ e $7^{\circ}$ anos; e sete de ensino médio, do $1^{\circ}$ ao $3^{\circ}$ anos. Turno vespertino, com doze turmas, sendo: três de ensino fundamental, de $5^{a}$ a $8^{a}$ séries $/ 7^{\circ}$ ano; nove de ensino médio, do $1^{\circ}$ ao $3^{\circ}$ ano. Turno noturno, com cinco turmas: duas de EJA, no ensino médio; três de ensino médio regular, $1^{\circ}$ ao $3^{\circ}$ anos (ESCOLA ESTADUAL DE ENSINO FUNDAMENTAL E MÉDIO FREI AMBRÓSIO, 2014).

A Escola está localizada no Bairro Centro, limita-se ao norte com o Rio Tapajós, ao sul com o Bairro Santa Clara, a leste com o Bairro Prainha e a oeste com o Bairro Aldeia. Por sua localização privilegiada, está rodeada de opções de lazer, entretenimento e pontos turísticos como o Centro Cultural João Fona, o Museu Dica Frazão, a Praça Barão de Santarém, a Praça do Pescador, a Orla Fluvial de Santarém, a Praça Mirante do Tapajós, os dois bares mais tradicionais da cidade Mascote (com mais de 75 anos de existência no mesmo lugar) e Mascotinho (ESCOLA ESTADUAL DE ENSINO FUNDAMENTAL E MÉDIO FREI AMBRÓSIO, 2014).

A Escola Frei Ambrósio tem como proposta, segundo seu Projeto Político Pedagógico (PPP), 2014/2015, "servir aos interesses da comunidade escolar garantindo a todos um ensino de qualidade, isto é, a apropriação dos conteúdos escolares básicos que tenham relevância na vida dos alunos".

O objetivo da Escola é ser referência na qualidade da ação educativa desenvolvida de forma crítica, participativa e transformadora. Nesse sentido, sua missão é "fornecer subsídios para o exercício da cidadania, por meio da aquisição de conteúdos, para uma participação organizada e ativa na democratização da sociedade" (ESCOLA ESTADUAL DE ENSINO FUNDAMENTAL E MÉDIO FREI AMBRÓSIO, 2014).

É dentro dessa proposta que a referida Escola empreende a Educação Patrimonial, que tem como fim a valorização da memória e história locais, o respeito às identidades, à alteridade, aos saberes e fazeres que singularizam o povo de Santarém, ou seja, o exercício da cidadania que só se torna possível quando se 
reconhece o outro enquanto um ser que constitui uma coletividade, que tem história, cultura, valores e que precisa ser respeitado frente às tentativas de hierarquizações étnicas e culturais globalizantes que, constantemente, tentam suprimir as diversidades locais. Portanto, a afirmação, amor e respeito à cultura local só é possível quando há conhecimento e valorização da mesma, pois o ser humano só aprende a amar aquilo que conhece - conhecimento que só é possível por meio de práticas educativas, sejam elas dentro ou fora dos muros da escola.

A Escola Frei Ambrósio, conforme seu PPP (2014/2015), tem como objetivo geral "formar cidadãos responsáveis, participativos e críticos para atuarem numa sociedade democrática" e, como objetivos específicos,

$>$ Aprimorar a qualidade do ensino oferecida aos alunos;

> Capacitar educandos para o exercício das atividades produtivas, aprimoramento das competências e habilidades necessárias para a atuação no mundo do trabalho e das práticas sociais que o circundam;

$>$ Garantir a inclusão de alunos com necessidades educacionais especiais;

> Buscar soluções ou parcerias para a resolução ou diminuição dos problemas existentes na escola;

> Fazer estatísticas constantes da situação do desempenho escolar dos alunos;

> Proporcionar um bom ambiente de trabalho no intuito de obter melhores resultados;

> Oportunizar aos educandos condições de ingressar no ensino médio;

> Oferecer aos educandos uma educação que prime pelo sucesso escolar e consciência crítica de todos (ESCOLA ESTADUAL DE ENSINO FUNDAMENTAL E MÉDIO FREI AMBRÓSIO, 2014).

Em seu Projeto Político Pedagógico, está contido que a ação escolar precisa ser planejada entre os atores envolvidos (gestão, professores e técnicos), desse modo, a proposta é uma nova forma de ensinar, baseada em trabalhos interdisciplinares, "buscando superar a fragmentação do conhecimento e formar um aluno com compreensão mais ampla da realidade". Suas propostas são:

$>$ Assiduidade;

$>$ Pontualidade;

Dinamismo;

> Comprometimento com o processo ensino-aprendizagem, bem como, participar de todas as atividades desenvolvidas na escola, incluídas no calendário escolar;

> Responsabilidade com a entrega das notas e avaliações;

> Docentes capacitados e comprometidos e conscientes com a educação, uma vez que as ações necessitam ser integradas e compartilhadas, visando o bom andamento da escola;

> Um trabalho interdisciplinar, promovendo assim, mudança na forma de ensinar, pois requer planejamento conjunto, motivados, empreendedores e criativos.

O perfil da Equipe Gestora da Escola Frei Ambrósio esta alicerçado na democracia e dialogicidade. Partindo destes princípios, o grupo decide o que é 
melhor para o ambiente escolar, estabelece regras e metas, procura superar entraves e divergências, a fim de construir objetivos comuns.

Conforme o PPP da Escola, "trabalhar coletivamente significa envolver ações e decisões de toda uma comunidade escolar [...] compartilhando responsabilidades, aceitando sugestões criativas e inovadoras, respeitando opiniões", com um propósito maior que é o ensino de qualidade.

A Gestão Democrática visa uma liderança com diálogo, mediação de conflitos, acatando as decisões em grupo com ética, a fim de uma educação de qualidade.

\section{O Organograma da Escola Frei Ambrósio está assim constituído ${ }^{14}$ :}

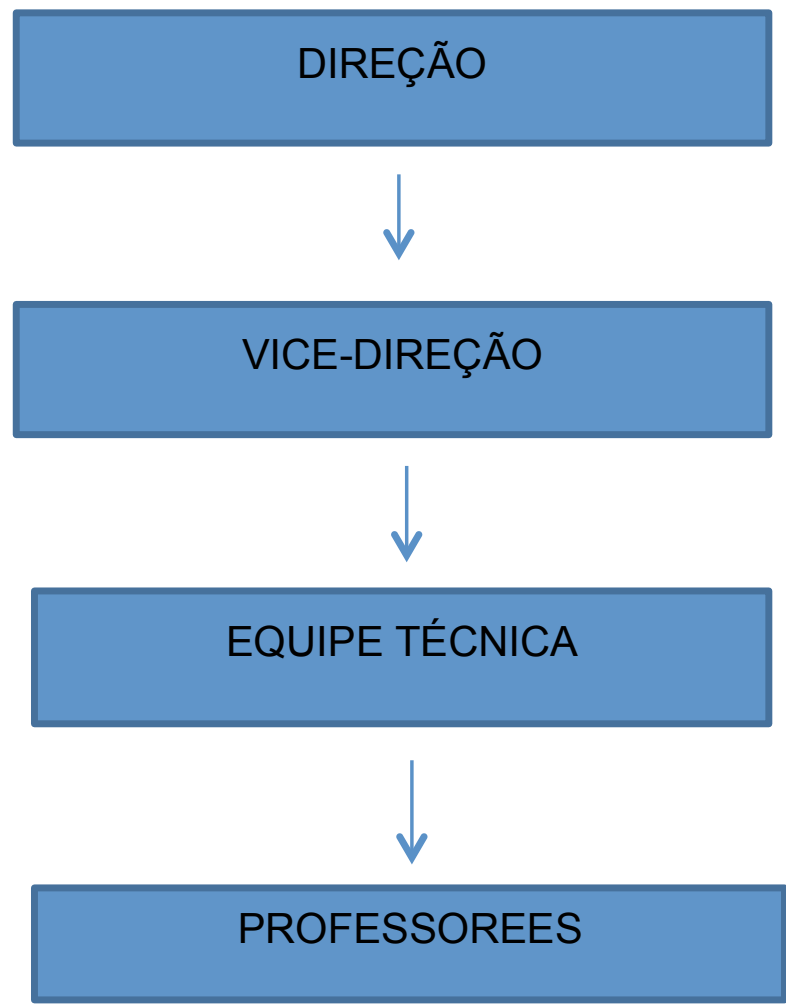

${ }^{14}$ Organograma confeccionado pelo pesquisador com base no Projeto Político Pedagógico da Escola 2014/2015. A escola possuiu um diretor, uma vice-diretora, três técnicos em educação (pedagogos) e vinte e sete professores efetivos. 
Quanto à descrição dos espaços, a Escola Frei Ambrósio está assim distribuída:

> 01 Sala de direção;

> 01 Sala do setor pedagógico;

> 01 Sala dos professores;

$>01$ Secretaria;

> 01 Biblioteca;

> 01 Sala de arquivo;

$>12$ Salas de aula;

> 01 Laboratório de informática;

> 01 Laboratório multidisciplinar;

> 01 Sala multimídia;

> 01 Suíte multimídia;

> 02 Recreios cobertos;

> 04 Depósitos;

> 01 Cantina;

> 01 Cozinha;

> 01 Banheiro para professores;

> 02 Banheiros para alunos;

> 01 Guarita com banheiro. 
Figura 54- Frente da Escola Frei Ambrósio

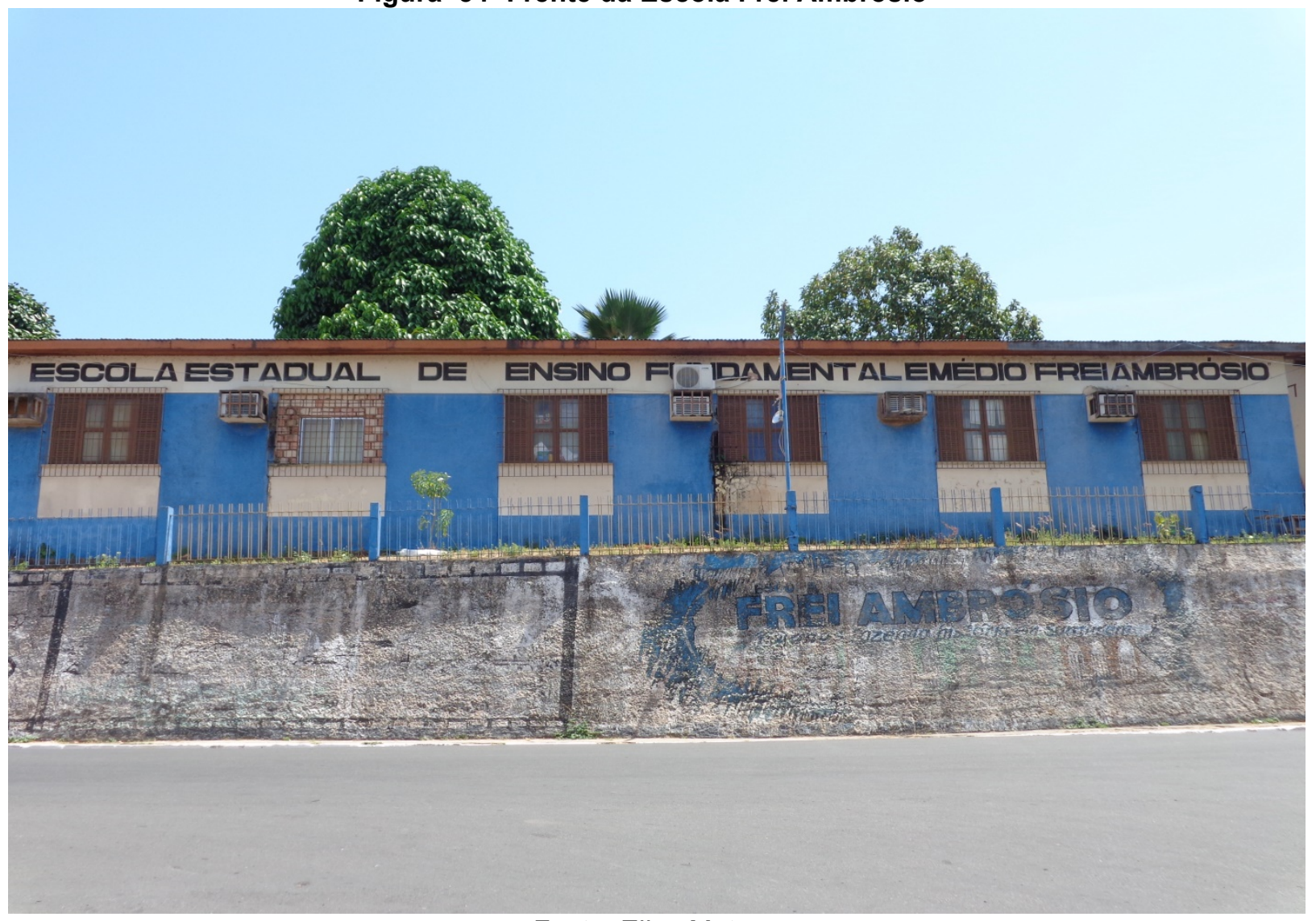

Fonte: Elias Mota

Figura 55 - Vista Aérea da Escola Frei Ambrósio

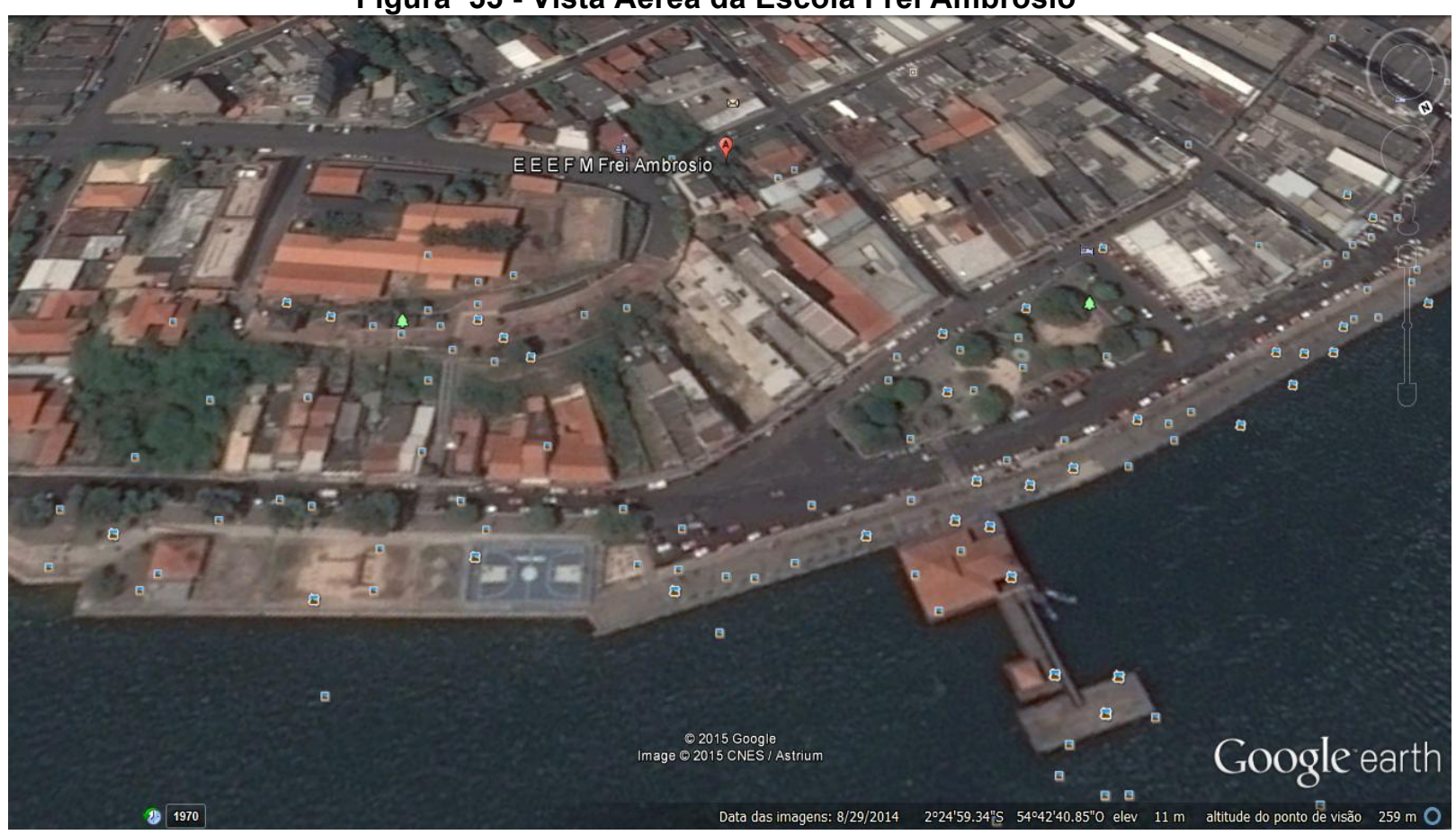

Fonte: Google Earth 
Figura 56- Pavilhão Principal da Escola Frei Ambrósio ${ }^{15}$

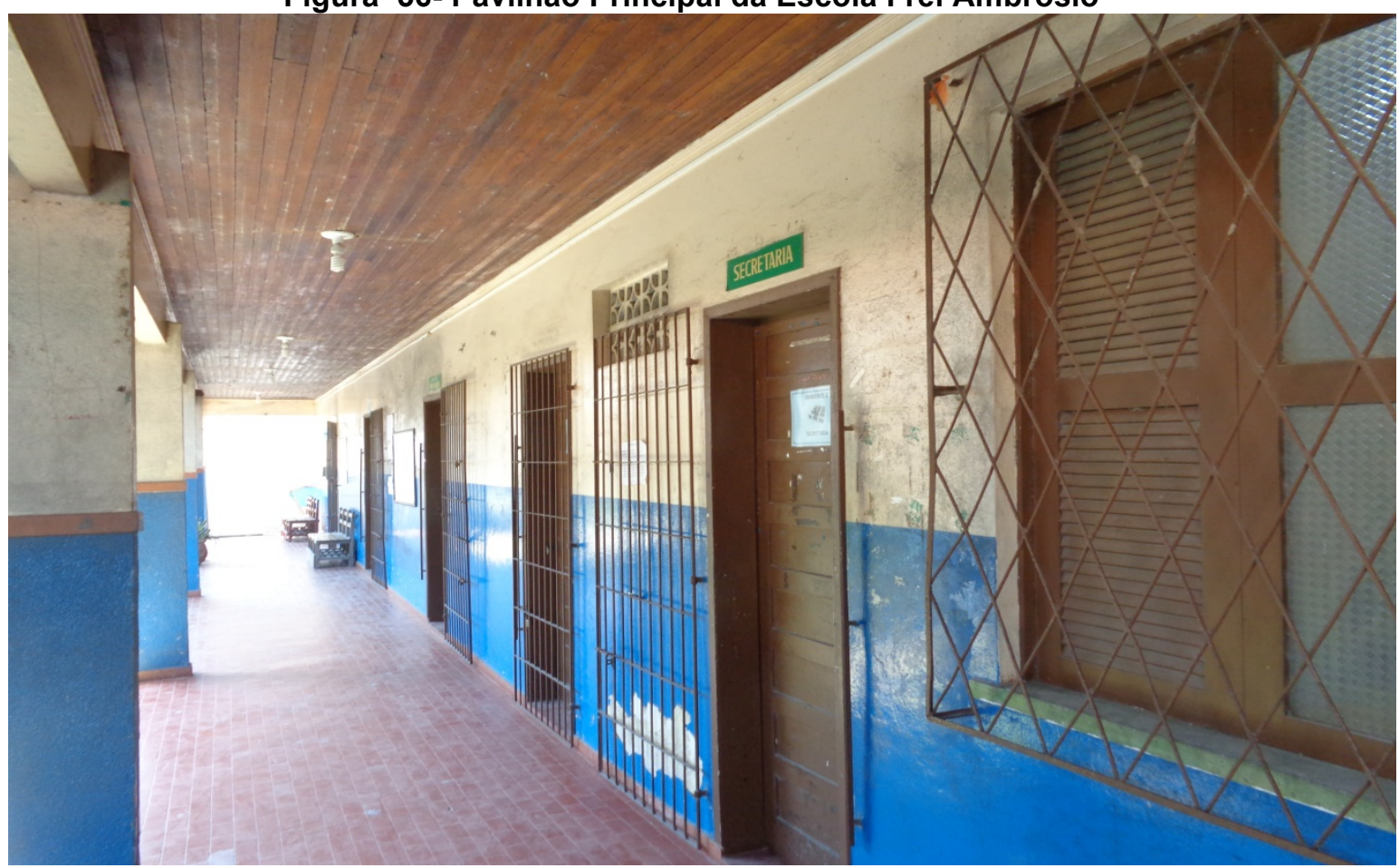

Fonte: Elias Mota

Figura 57-Entrada da Biblioteca da Escola

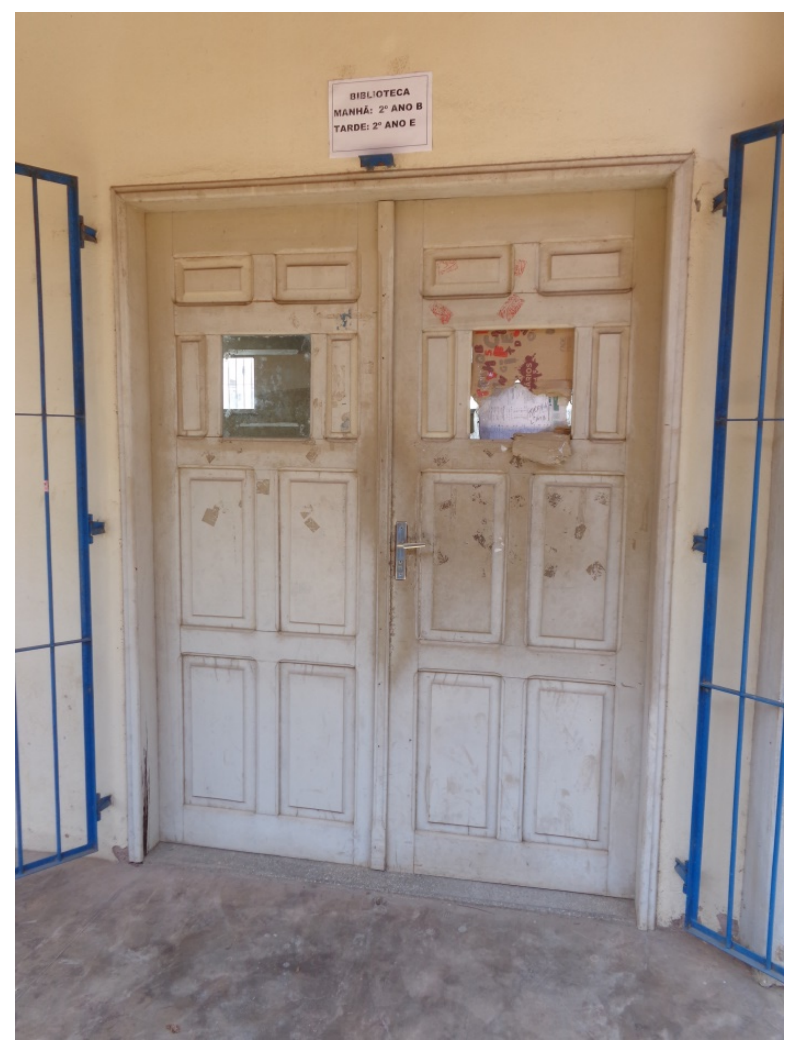

Fonte: Elias Mota

${ }^{15} \mathrm{Na}$ sequência: Secretaria da Escola, Sala de Material Esportivo, Sala dos professores, Equipe pedagógica e Direção da Escola. 
Figura 58- Copa Cozinha da Escola

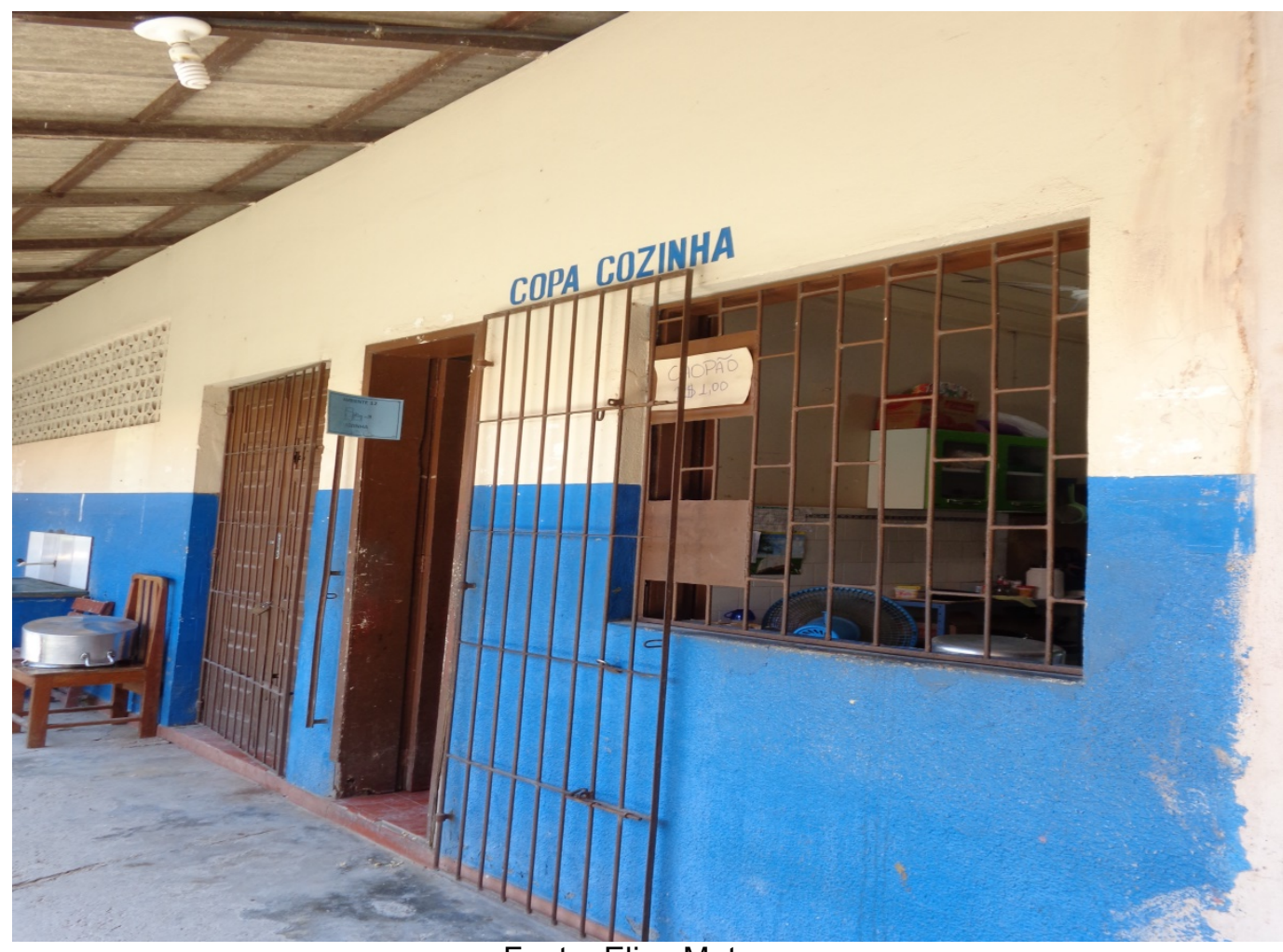

Fonte: Elias Mota

Figura 59 - Cantina da Escola

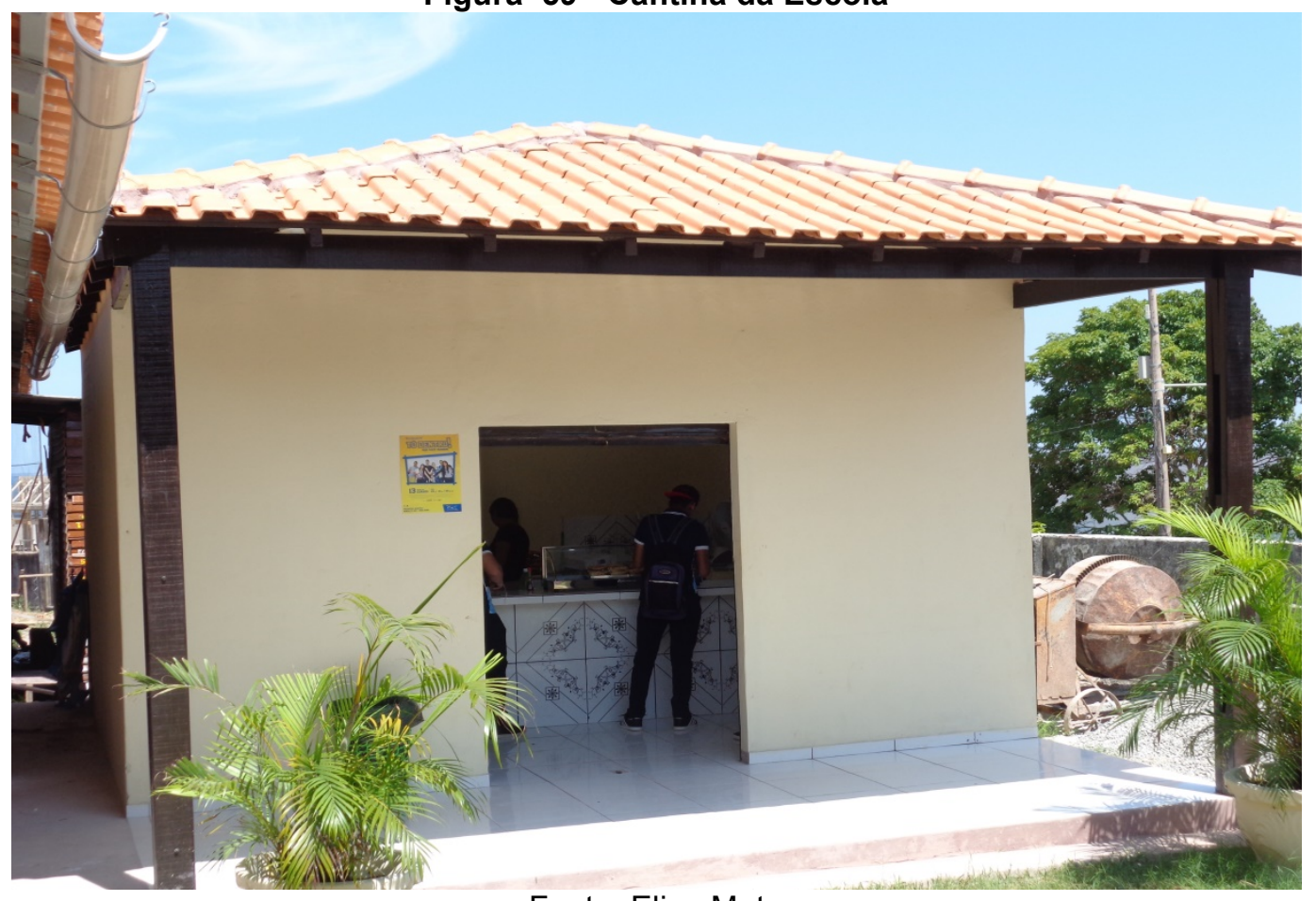

Fonte: Elias Mota 


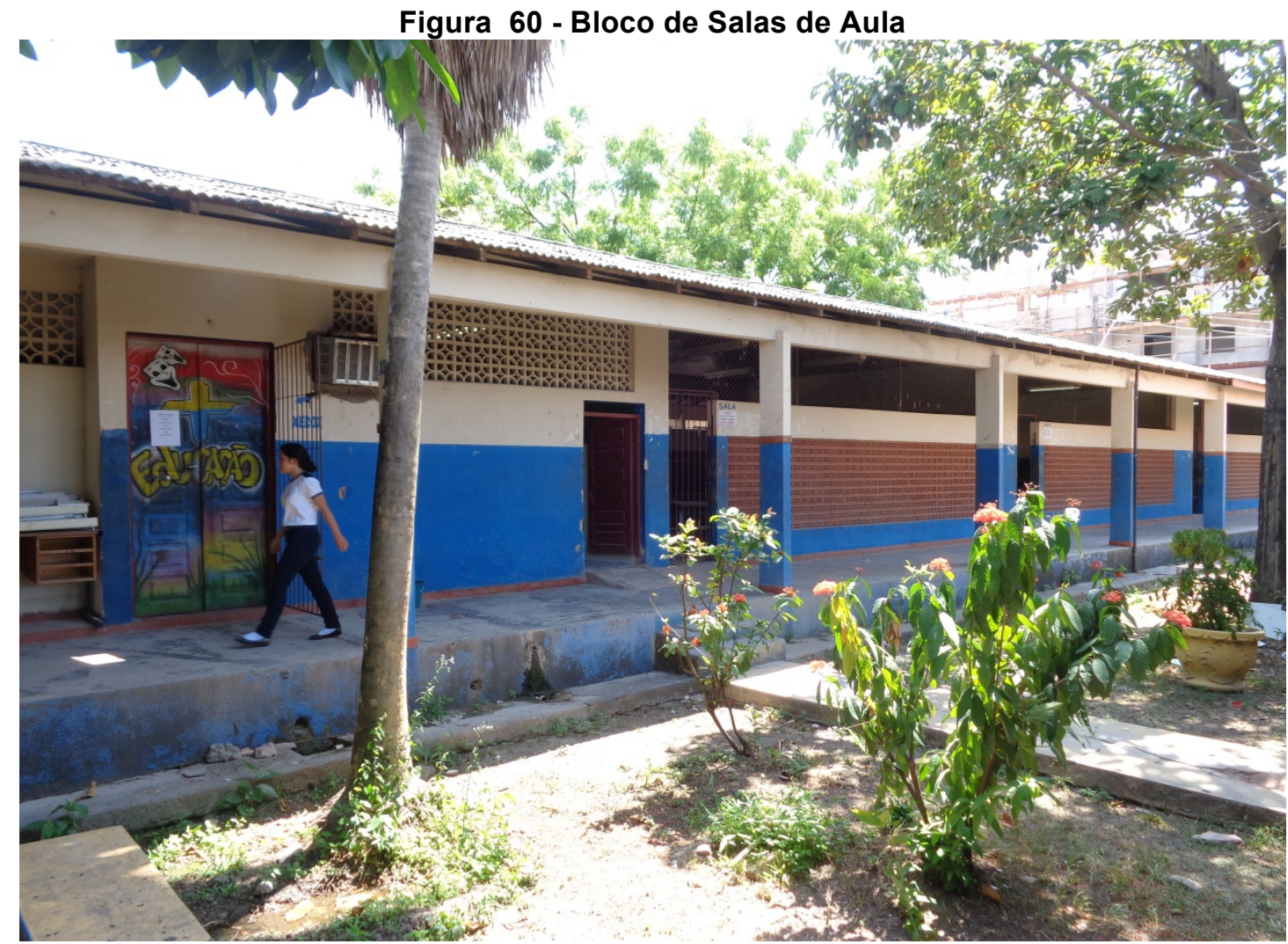

Fonte: Elias Mota

Figura 61 - Bloco de Salas de Aula em Reforma

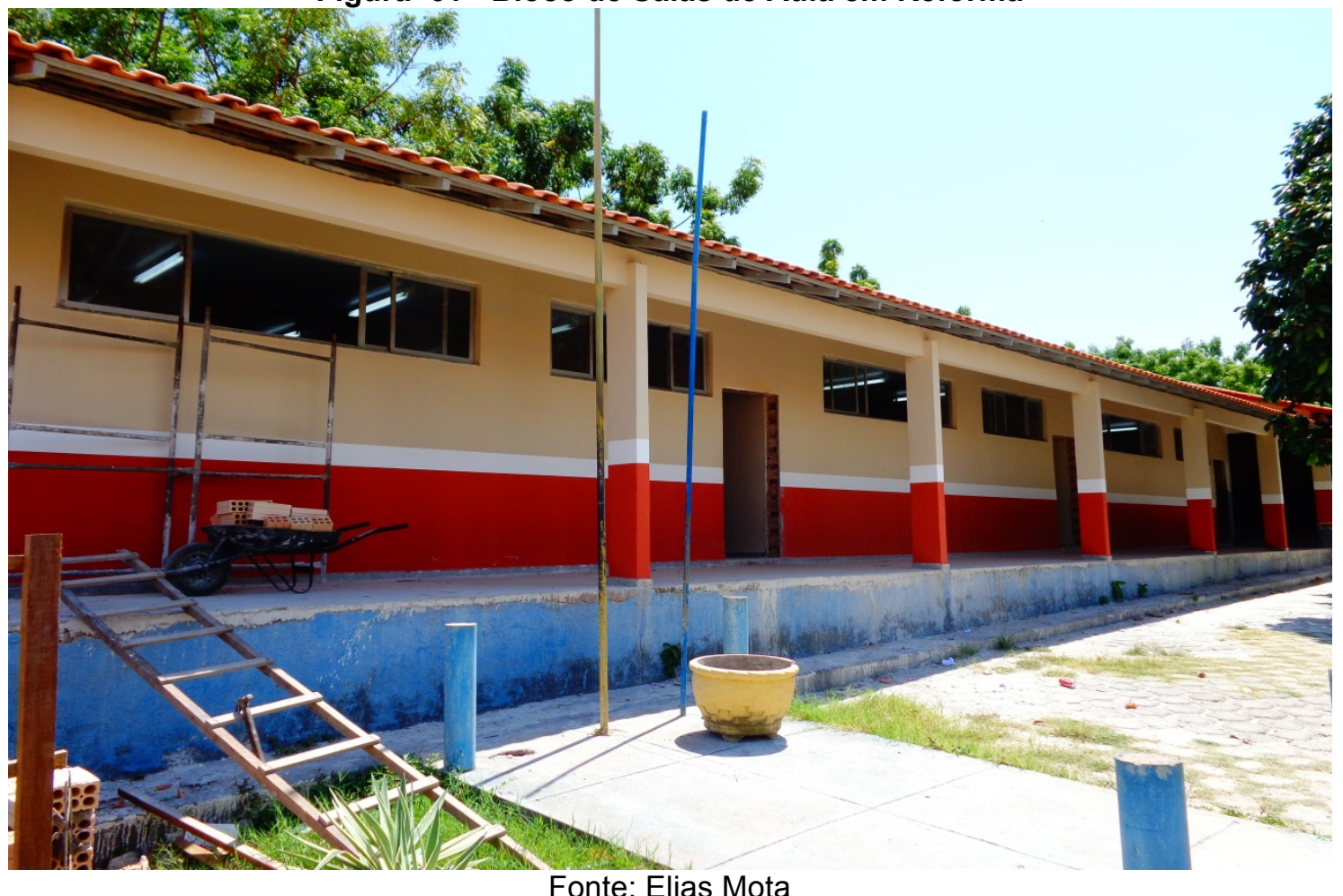

Fonte: Elias Mota 
Figura 62 - Quadra de Esporte da Escola

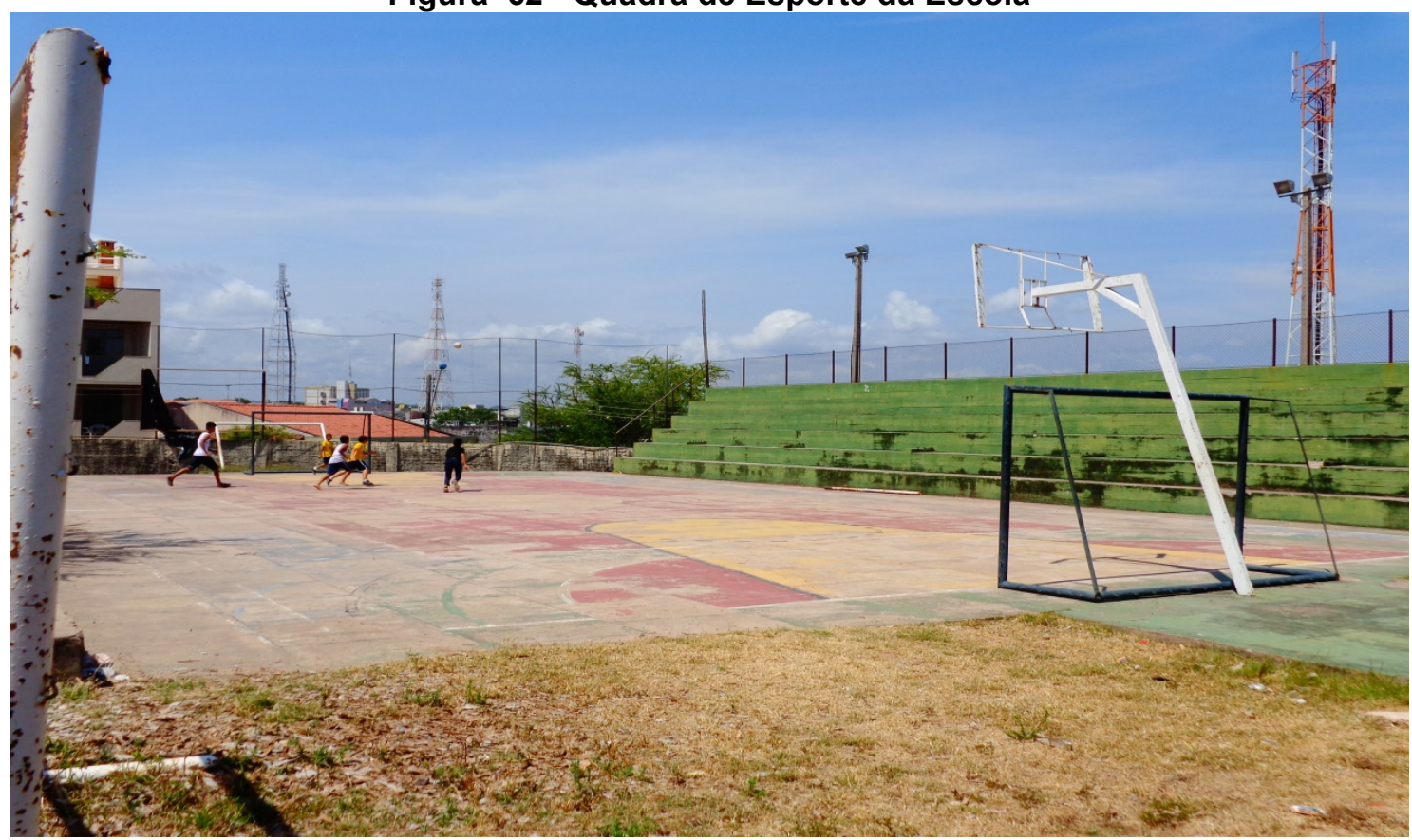

Fonte: Elias Mota

Figura 63 - Construção do Auditório da Escola

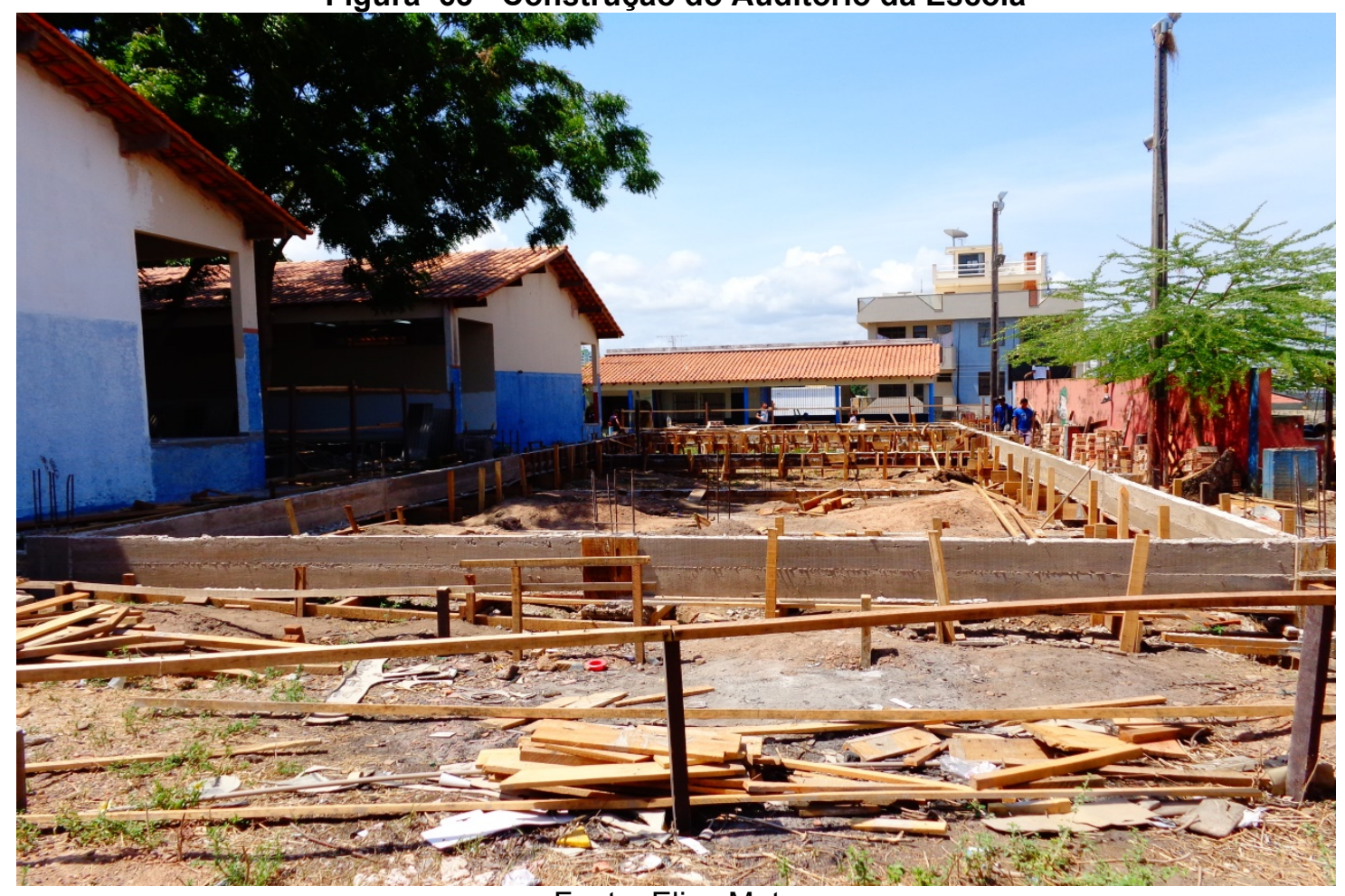

Fonte: Elias Mota 
Figura 64 - Jardim na Entrada da Escola

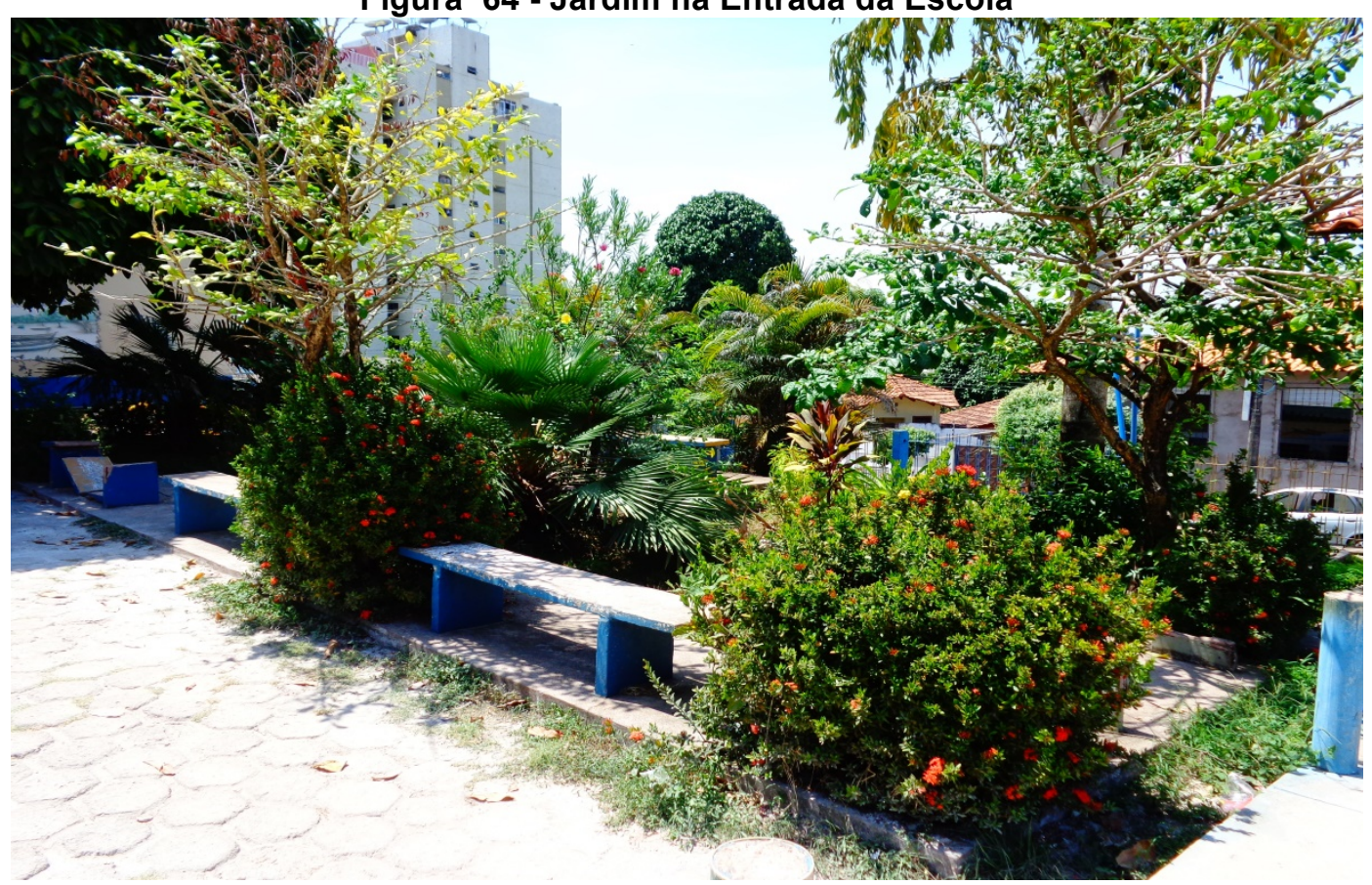

Fonte: Elias Mota

Figura 65 - Portão de Entrada da Escola

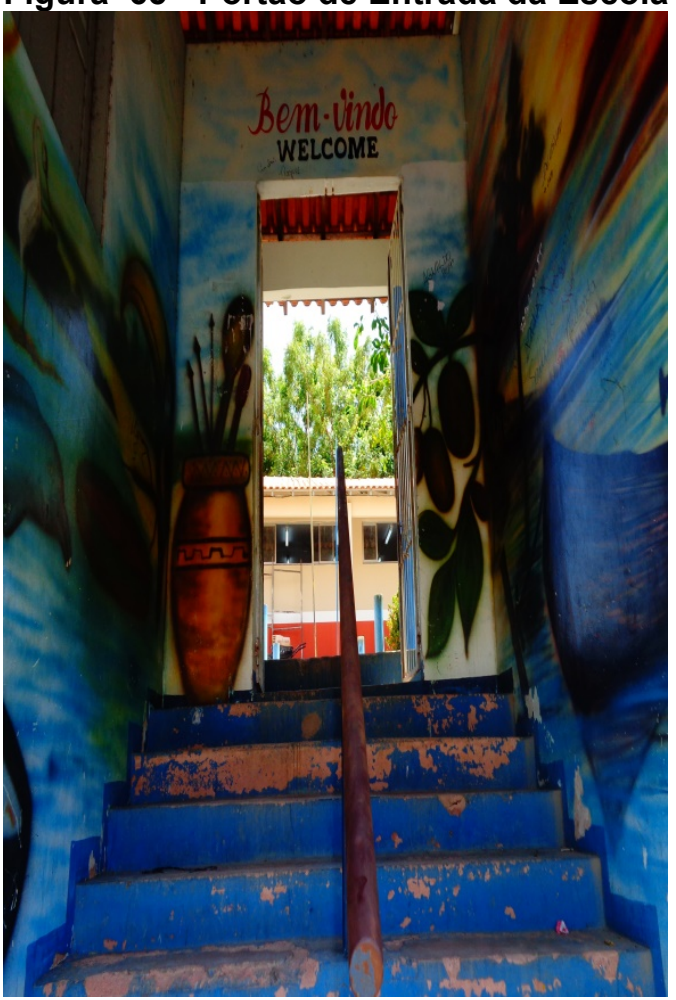

Fonte: Elias Mota 
Figura 66 - Busto de Frei Ambrósio

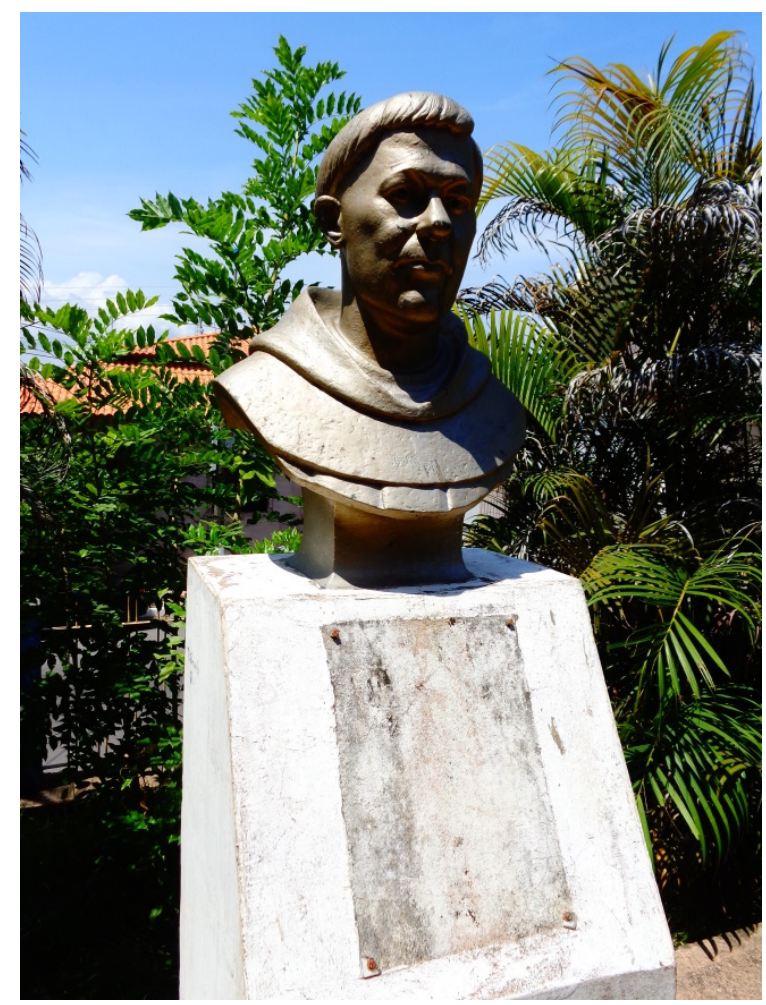

Fonte: Elias Mota

A Escola Frei Ambrósio, visando à construção desse sujeito histórico, desenvolve muitos programas, projetos e ações voltados para a cultura local, regional e nacional, Cidadania e história da Escola, como importante indutora da educação no município, elencados a seguir: Programa Ensino Médio Inovador (PROEMI), Mais Educação, Programa Nacional do Livro Didático (PNLD), Programa Nacional de Alimentação Escolar (PNAE), Programa de Desenvolvimento Educacional (PDE) e Programa Dinheiro Direto na Escola (PDDE). Os projetos desenvolvidos na escola são: ENEM Solidário, Sol Cidadão Legal, Projeto Fanfarra (envolve alunos e ex-alunos), Feira do Conhecimento, Africanidade (nossas raízes, anual) e Resgate da história da Escola. Existem, também, algumas ações que são desenvolvidas na escola como: o Processo Avaliativo Bimestral (PROABI); o aniversário da Escola, no mês de maio; a Festa Junina, no mês de junho; os Jogos Internos, no mês de dezembro; parceria com o Serviço Social do Comércio (SESC), sobre Doenças Sexualmente Transmissíveis (DSTs); o conselho de classe e reunião de pais.

Após a apresentação da Escola Frei Ambrósio, partir-se-á para a pesquisa de campo que foi realizada no período de setembro a dezembro de 2014 , onde foram 
entrevistados dez alunos do ensino fundamental e cinco professores do ensino fundamental e médio. Os alunos foram, a princípio, indicados pelos professores por serem considerados os mais interessados em sala de aula, os que mais participam, os questionadores, aqueles com os melhores rendimentos em conceito. Porém, alguns dos alunos convidados não participaram das entrevistas, ora porque se recusaram, ora porque seus responsáveis não concordaram que seus filhos participassem da pesquisa.

Dos dez alunos entrevistados, nove são do gênero feminino e um do gênero masculino. A fim de preservar a identidade de cada um, eles são tratados nessa pesquisa como aluno. Pela ordem que foram entrevistados, dessa forma, o aluno 1 foi o primeiro a ser entrevistado.

O elenco dos professores foi delimitado por serem os que lecionam as disciplinas que mais se aproximam do o universo da pesquisa, ou seja, História, Estudos Amazônicos, Educação Artística, Artes e professores envolvidos com projetos que abordam a temática da Cidadania e Patrimônio. Quanto ao gênero, foram entrevistados quatro professores do gênero feminino e um professor do gênero masculino. E para preservar suas identidades, serão denominados, nesta pesquisa, de professor A, B, C, D e E, de acordo com a ordem em que foram entrevistados.

As entrevistas com os alunos foram realizadas na sala da coordenação pedagógica e na sala dos professores. Já as entrevistas com os professores foram realizadas em sala de aula, corredor da Escola e área de recreio da instituição. Para os alunos, foram elencadas perguntas abertas (conforme apêndice 2). As perguntas de um a cinco dizem respeito à identificação dos alunos (nome, endereço, contato, idade e série), a partir da pergunta de número seis, cada um falou sobre o seu entendimento ou não das interrogações.

O tempo de duração das entrevistas foi bem flexível, ficando o entrevistado a vontade para expor sua opinião e conhecimento acerca das questões propostas. Os alunos tiveram mais dificuldades para se expressar, visto que, para eles, não é comum participarem de pesquisas e exporem suas opiniões. A princípio, mostraramse tímidos e arredios, mas com o passar do tempo foram tomando gosto pelos assuntos propostos. Em média, vinte a vinte e cinco minutos foi o tempo que cada aluno respondeu as indagações do pesquisador. 
Em relação aos professores, o tempo foi um pouco maior, cerca de quarenta a cinquenta minutos para cada um expor seu ponto de vista sobre as questões propostas.

Todas as entrevistas com os alunos e professores foram realizadas durante turno matutino e noturno, em função do pesquisador desenvolver suas atividades laborais durante o turno vespertino.

A técnica de entrevista semiestruturada, como instrumento de pesquisa, foi de capital importância para a realização deste trabalho, pois, através dela foi possível extrair fragmentos de falas que são, nada mais, nada menos, representações dos alunos e professores sobre o Patrimônio Histórico Cultural, Educação Patrimonial e a relação destes com a história local. Tais representações serão entendidas, neste texto, conforme a acepção de Sandra Pesavento (2005): uma forma de ver e dar sentido à realidade que é construída na e pela experiência humana. Por esse viés, entende-se que os pesquisadores não têm acesso ao real em si, mas apenas às significações que os seres humanos constroem sobre ele.

Dentro dessa perspectiva, afirma-se que as representações expressam a maneira como as pessoas entendem e significam a realidade social, inscrevendo nela sentidos que são sócio-culturalmente construídos e partilhados por determinados grupos sociais. São, portanto, constituintes de um conceito maior, o de cultura. Para Geertz (1989, p. 4),

O conceito de cultura [que ele defende] é essencialmente semiótico. Acreditando, como Max Weber, que o homem é um animal amarrado a teias de significados que ele mesmo teceu, [ele assume] a cultura como sendo essas teias e a sua análise; portanto, não como uma ciência experimental em busca de leis, mas como uma ciência interpretativa, à procura do significado.

Afirma-se que o Patrimônio Histórico é parte de nossa cultura, haja vista sua adjetivação como cultura. É, portanto, tecido dentro dessa rede de significados, por meio da qual os seres humanos dão sentido ao mundo que os rodeia. Seu sentido, porém, não é estático, está em constate processo de ressignificação, sujeito, desse modo, às mudanças temporais.

Portanto, são os grupos sociais quem elegem seus patrimônios históricos e culturais, devido ao valor, ao significado que esses patrimônios têm para esses grupos. A construção desses significados implica processos de identificação de um 
povo, um grupo com suas manifestações culturais, seus saberes e fazeres, monumentos, tradições etc., ou seja, aquilo que o grupo elege como representativo de sua história, de sua cultura, de sua identidade.

\subsection{Com a palavra Os Alunos}

Em Gonçalves (2009), a palavra Patrimônio aparece como uma das mais utilizadas no cotidiano das pessoas. Fala-se em patrimônio econômico, financeiro, imobiliário, cultural, arquitetônico, histórico, artístico, ecológico, genético, imaterial, dentre outros. Nas vozes dos alunos não poderia ser diferente, aparecendo como categoria polissêmica. Vejamos:

"Patrimônio...Áh, Patrimônio né? É uma coisa que a pessoa tem posse, que ela pode guardar..." (Aluno 1)

A leitura que este Aluno tem de Patrimônio está relacionada à ideia de posse, algo que se pode guardar, acumular. No primeiro momento, a afirmativa do Aluno está em consonância com os apontamentos de Abreu (2009, p. 34-35), o qual afirma que no "sentido jurídico, [o patrimônio] refere-se a um complexo de bens, materiais ou não, direitos, ações, posse e tudo o mais que pertença a uma pessoa ou empresa e seja suscetível de apreciação econômica". No segundo, pode-se dizer que está relacionado à ideia de matéria tangível.

Mas, a noção de Patrimônio remete também a ideia de propriedade:

"Bom pra mim Patrimônio é tudo o que é seu né...Patrimônio é...Tudo que é seu, algo que você possui" (Aluno 2).

Nessa perspectiva, o Patrimônio é entendido como um bem que é do indivíduo, que pode ser desde uma casa, um carro, uma joia, ou ainda uma fotografia antiga que traz um valor sentimental; "um livro autografado ou uma imagem religiosa do nosso altar doméstico" (FUNARI E PELEGRINI, 2006, p. 8). A Superintendência do IPHAN (2012, p. 12), na Paraíba, corrobora para o debate ao postular que "a ideia de Patrimônio não está limitada apenas ao conjunto de bens materiais de uma comunidade ou população, mas também se estende a tudo aquilo que é considerado valioso pelas pessoas". 
O Patrimônio é visto, ainda, como algo que a pessoa conquista, está associado a um bem que pode ser móvel ou imóvel, adquirido através de compra.

"Bom, Patrimônio é aquilo que a gente conquista, Patrimônio pode ser a nossa casa, Patrimônio que a gente conquistou, o nosso carro, uma fazenda a gente tenha comprado, uma pousada, pra mim esse é o Patrimônio, aquilo que a gente conquista" (Aluno 3).

Nesta fala, percebe-se o Patrimônio associado a algo material. Para Gonçalves (2009, p. 27), "a noção de Patrimônio confunde-se com a de propriedade". Essa afirmação de Gonçalves é compartilhada com muitos outros teóricos, entre eles Dencker (2012) e Abreu (2009).

Outra perspectiva de Patrimônio é revelado pelo Aluno 4, ao inferir que:

"Pra mim o Patrimônio é um bem onde a sociedade valoriza e tem o dever de zelar juntamente com o poder público" (Aluno 4).

Através da fala deste aluno, evidencia-se o Patrimônio como bem de todos, um bem coletivo. Logo, a comunidade e o poder público devem zelar por sua preservação e conservação, afinal como expressa o Artigo 216 da Constituição Federal, inciso $1^{\circ}$, "o poder público, com a colaboração da comunidade, promoverá e protegerá o Patrimônio Cultural Brasileiro". A fala do Aluno 4 remete a afirmação de Pelegrini (2009, p. 35): “a preservação [...] do Patrimônio material e imaterial contribui para aflorar afetos que estimulam o sentido de pertencimento da comunidade".

O Patrimônio visto como herança tem aporte nos apontamentos de Choay (2006), Barretto (2002), Poulot (2009), Chuva (2009), dentre outros, que entendem esse bem como um legado que é transmitido de geração em geração. Essa é a visão do depoente.

"Os bens deixados pelos nossos antepassados" (Aluno 5).

Essa afirmação dialoga com a posição de Choay (2006) sobre o patrimônio, quando afirma que são os bens, herança que são transmitidos pelos pais aos filhos. Ou ainda, Littré apud Poulot (2009, p. 17), os quais dizem que o "patrimônio referese aos bens de herança [...], passam, segundo as leis, dos pais e das mães para sua filiação".

Em Machado (2004, p. 10), o Patrimônio é tratado como: 
Conjunto de bens produzidos por outras gerações, ou seja, os bens resultantes da experiência coletiva que um grupo deseja manter como perene. Nesse sentido, Patrimônio supera a definição estreita de um conjunto estático de objetos, construções, documentos, obras, etc., sendo uma marca um vestígio cultural, que individualiza os homens em momentos temporal e culturalmente diferentes.

Pelegrini $(2009$, p. 23) corrobora para o debate ao afirmar que "os bens culturais tomados como 'legado vivo' que recebemos do passado, vivemos no presente e transmitimos às gerações futuras, reúnem referenciais identitários, memórias e histórias", elementos essenciais para a formação do cidadão, haja vista que a formação para a cidadania requer exercício de direitos e deveres, dentre os quais o respeito à diversidade cultural, à alteridade, o que pressupõe conhecimento da história e reconhecimento e respeito do outro como portador de identidades historicamente construídas.

O Patrimônio também está relacionado à transmissão, legado, algo que teve grande significado e valor no passado e que é considerado importante para o presente e para o futuro dos grupos sociais. Nessa perspectiva:

"Patrimônio pra mim é tipo algo importante, aquilo que ficou lá atrás... Agora, que a gente vai... Por exemplo, a gente vai precisar, é nosso, eu digo que há muito tempo atrás, as pessoas utilizavam né, construíam, fabricavam, alguma coisa e deixaram agora pra nova geração né, pra essa nova geração, acredito que seja isso o patrimônio, que a gente vai utilizar tudo isso" (Aluno 6).

Para este Aluno o Patrimônio remete também a ideia de utilização, ou seja, algo que a presente geração pode usufruir.

Num primeiro momento, o Patrimônio é entendido pelo Aluno 7 como um "lugar histórico" de todos e antigo. O lugar histórico pode ser entendido, nesta pesquisa, como o Centro Histórico de Santarém e todos os seus bens patrimoniais, como por exemplo, a Igreja Matriz de Nossa Senhora da Conceição, citada por quase todos os alunos entrevistados, ou ainda os sobrados e casarões espalhados pelo Centro Histórico, bem como a Escola Frei Ambrósio. Nesse sentido, Horta et al. (1999) postulam:

Os Centros Históricos de muitas cidades do Brasil são excelentes para estimular o professor e seus alunos a estabelecer e compreender as relações fundamentais entre o presente, o passado, e as mudanças ocorridas nos modos de vida das pessoas que neles viveram, assim como nas próprias cidades (HORTA et al. p. 26). 
Dois dos alunos, 4 e 7, fizeram a afirmativa de que o Patrimônio é um bem que pertence a todos e que cabe a todo cidadão zelar pelos bens patrimoniais, bem como fiscalizar as ações dos governos e órgãos competentes por sua salvaguarda. Tais afirmativas sinalizam que o sentido do patrimônio cultural já permeia o imaginário de alguns estudantes. Fruto de um trabalho contínuo de educação, que tem o patrimônio cultural como um de seus objetos, percebe-se, através das falas dos alunos, que a Escola Frei Ambrósio tem desenvolvido práticas de ensino aprendizagem que aguçam a consciência crítica sobre o valor dos bens patrimoniais, sua importância para a memória e história local, e a responsabilidade que cada ser humano tem sobre sua salvaguarda, portanto, uma educação que prepara o educando para o exercício da cidadania.

"É uma... Um lugar que é histórico, é tudo o que é nosso. Uma coisa antiga".(Aluno 7)

Para o Aluno 8, Patrimônio é um monumento importante para a história de um povo. Horta et al. (1999, p. 16) afirmam que monumento "é uma edificação ou sítio histórico de caráter exemplar por seu significado na trajetória de vida de uma sociedade/comunidade e por suas características peculiares de forma, estilo e função". Dentro dessa perspectiva, e considerando a afirmação do Aluno 8, percebese que em Santarém existem monumentos representativos da história da cidade, a exemplo disso a Intendência, atual Centro Cultural João Fona. Este monumento/patrimônio guarda, em sua estrutura arquitetônica, ressonâncias do outrora que, por não serem alheias ao tempo, estão sujeitas às ressignificações construídas pelos olhares dos sujeitos, os quais inscrevem, através de práticas discursivas, sentidos histórico-culturais aos bens que elegem como referências de suas identidades.

"É um... Um monumento que ficou para a história" (Aluno 8).

Outros monumentos foram erguidos para marcar a importância que algumas pessoas tiveram para a cultura, educação e história daquela comunidade, a exemplo, o busto de Frei Ambrósio, destacado no terceiro capítulo desta pesquisa (Figura 66). 
O Patrimônio, na atualidade, é entendido amplamente como nos orienta Fonseca (2012, p. 5): "o patrimônio é tudo o que criamos, valorizamos e queremos preservar: são os monumentos e obras de arte, e também as festas, músicas e danças, os folguedos e as comidas, os saberes e falares [...], as ideias e a fantasia". $\mathrm{Na}$ perspectiva de Fonseca, portanto, está calcada a ideia de Patrimônio na contemporaneidade.

O Patrimônio Cultural, conforme a Superintendência do IPHAN na Paraíba (2012, p. 12), "é o conjunto de saberes, fazeres, expressões, práticas e produtos considerados de grande valor para uma sociedade ao longo da sua história". A Educação Patrimonial tem no Patrimônio Cultural sua fonte primária de conhecimento, a fim de um enriquecimento individual e coletivo (HORTA et al., 1999). Portanto, ela utiliza-se do Patrimônio Cultural nas suas mais variadas vertentes, a fim de levar o conhecimento, apropriação e valorização desse Patrimônio para crianças, adultos e idosos num processo contínuo de enriquecimento cultural, haja vista ser o Patrimônio não só um construto, algo tecido dentro da rede de significados que Geertz (1989) define como cultura, como também um instrumento que possibilita ao ser humano conhecimento sobre a cultura, por ser uma fonte de acesso à história, à memória, à experiência e identidades de um povo. Nesse aspecto, o Patrimônio é expressão da cultura, como também, por meio da Educação Patrimonial, possibilita o acesso à cultura.

Partindo do pressuposto de que a Educação Patrimonial é um importante meio de transformação social, procurou-se, nesta pesquisa, analisar o entendimento que os alunos têm sobre a Educação Patrimonial. Ao serem inquiridos, os alunos se posicionaram da seguinte forma:

\footnotetext{
"Já ouvi falar algumas vezes, algumas vezes...Educação Patrimonial ensina a respeitar o patrimônio da cidade, do estado, o seu próprio patrimônio, como casa e da cidade o museu...É...o zoológico, esse tipo de coisa que tem na cidade" (Aluno 1)

"Na verdade não, nunca ouvi falar em Educação Patrimonial, mas na minha opinião é tipo, vou dar um exemplo que o Frei Ambrósio (se referindo a escola a qual estuda), é uma escola patrimônio, vamos supor, e eu acho que...A Educação Patrimonial é a educação que a gente tem aqui, uma educação de longa data. Que eles dão a mesma educação que antes" (Aluno 2).

"Educação Patrimonial...Talvez o ensinamento sobre... Mais sobre o patrimônio" (Aluno 3).
} 
Através da fala dos alunos, pode-se perceber que a Educação Patrimonial ensina a respeitar o bem público (Aluno 1), ou seja, todo bem construído e que, por sua natureza pública, deve ser zelado pelo poder público; um legado transmitido de geração a geração (Aluno 2); práticas de ensino aprendizagem que explore, enquanto fonte do saber, os bens patrimoniais (Aluno 3).

O posicionamento dos três alunos descortina uma polissemia de significados sobre a Educação Patrimonial, que vai desde o respeito por tudo o que pertence a uma coletividade, aos legados transmitidos pelos seus antepassados.

Talvez, por ser uma novidade entre eles, muitos alunos não souberam responder a questão proposta.

A compreensão que tem os alunos 1 e 3 está coerente como que postulam os estudiosos do assunto, pois através do conhecimento, conscientização, sensibilização e respeito aos bens patrimoniais, os indivíduos estão praticando a Educação Patrimonial.

A Escola Frei Ambrósio desenvolve alguns projetos que contemplam ações de Educação Patrimonial, porém os alunos não têm esse esclarecimento e entendimento. Eles têm a prática, porém a teoria ainda precisa ser melhor trabalhada. Contudo, pode-se dizer que existe sim Educação Patrimonial na Escola Frei Ambrósio, uma vez que os professores levam seus alunos para conhecerem os museus da cidade, conversarem com os atores que lá se encontram, e receberem informações preciosas sobre a história da Cidade e suas transformações ocorridas no decorrer do tempo.

Sobre a importância que o museu tem para a Educação Patrimonial, recorreuse a Canclini (2006), no Capítulo 4, da obra Culturas Híbridas, O povir do passado, onde o autor relata como o museu de antropologia do México é importante para a história, memória e identidade daquele país, com ênfase para o indígena. Um museu para que os nativos sintam orgulho de serem mexicanos. Da mesma forma, o Centro Cultural João Fona, mais conhecido como Museu de Santarém, guarda em seu acervo importantes obras de arte, artefatos de cerâmica tapajônica e muitos outros elementos que deveriam servir de orgulho para os que nasceram em Santarém. Dessa forma, levar os alunos para visitarem os museus é importante ação de Educação Patrimonial.

Ao visitarem igrejas localizadas no Centro Histórico de Santarém e receberem informações sobre a história, a importância do bem patrimonial para a cultura, 
identidade e memória, como também participarem de feiras culturais, onde são exploradas as categorias história local, regional e nacional, história da Escola, patrimônio, cultura, identidade e memória, estão recebendo Educação Patrimonial. No âmbito do Projeto Mais Educação, desenvolvido pela Escola Frei Ambrósio, os professores introduzem a Educação Patrimonial, por meio de atividades pedagógicas, que têm como foco o conhecimento sobre o Festival do Sairé ${ }^{16}$, sua importância para a cultura local, sua herança indígena, sua tradição de mais de trezentos anos e todas as transformações e ressignificações que o evento sofreu com o passar do tempo. A difusão desse conhecimento extrapola o campo teórico, pois, além da teoria, os alunos têm contato direto com a festa, vivenciam-na. Como atividade educativa, são chamados a registrarem o evento com fotografias $e$ filmagens - material que, posteriormente, é trabalho na ambiência escolar.

Figura 67- Alunos do Projeto Mais Educação Participando do Festival do Sairé 2014 -

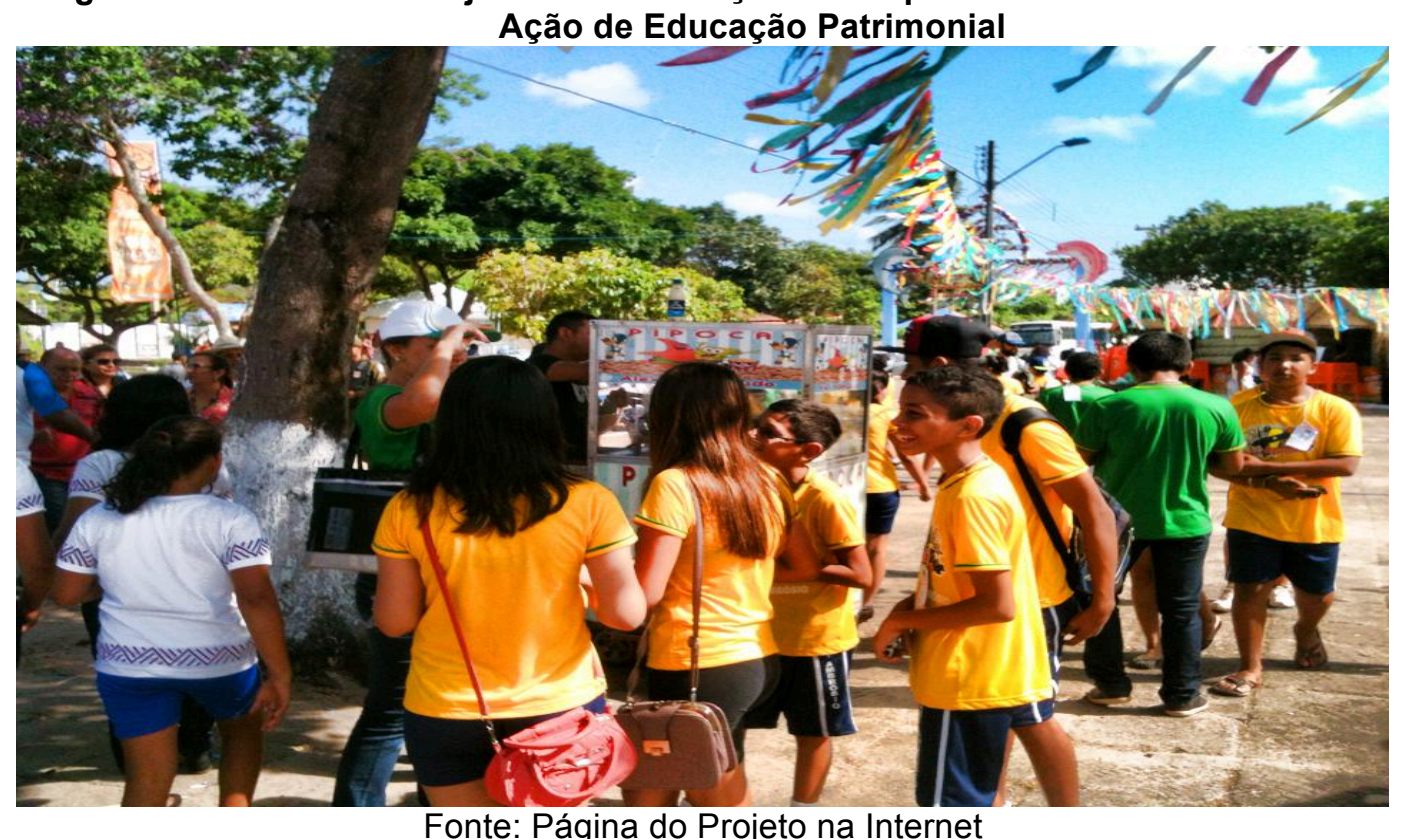

Ao terem o conhecimento sobre a importância dos bens patrimoniais, estes alunos poderão se reconhecer como parte deles e como algo que é seu. Dessa forma, a Educação Patrimonial "é também um processo que se aplica para além das paredes das salas de aula ou dos muros das escolas, já que envolve diretamente a

\footnotetext{
${ }^{16}$ O Festival do Sairé é uma manifestação cultural que acontece na Vila Balneária de Alter do Chão distante de Santarém a aproximadamente $35 \mathrm{~km}$ do centro de Santarém. Faz parte do calendário de eventos do Estado, já existe a mais de trezentos anos, ocorre na segunda semana de setembro e atrai milhares de pessoas todos os anos. É herança dos índios Boraris, antigos habitantes da Vila Balneária.
} 
sociedade e sua percepção de o que são e o que os representa" (SEABRA e TABOSA, 2012, p. 68).

Existe, ainda, na Escola um trabalho de valorização da mesma como Patrimônio Edificado da Cidade, sua importância para a educação, sua história e localização privilegiada. Através da semana e gincana culturais, os professores de História, Estudos Amazônicos, Artes e Educação Artística mobilizam os alunos a participarem ativamente desses eventos que tem como objetivo principal levar 0 conhecimento acerca da história da Escola, perquirindo sua trajetória, desde o primeiro prédio onde foi fundada, passando pelo segundo, até chegar ao espaço onde funciona na atualidade.

Essa valorização da história da Escola ficou evidente nas entrevistas com os alunos, na medida em que a maioria deles tem o conhecimento da importância da mesma enquanto bem patrimonial e educacional para Santarém. Isso mostra como o conhecimento e a informação são importantes para a noção de pertencimento e, consequentemente, do zelo/cuidado com o Patrimônio. O processo de Educação Patrimonial, tal qual desenvolvido pela Escola Frei Ambrósio, tem como premissa uma educação que preza pelo exercício da cidadania, aguçando nos alunos práticas de valorização do patrimônio histórico cultural da cidade onde moram, na tentativa de formação do turista cidadão. Este pode ser o próprio habitante da cidade onde encontram-se os bens patrimoniais, pois a partir do momento em que os alunos, habitantes de Santarém, são levados a visitar os bens patrimoniais de sua cidade e ali, através de práticas pedagógicas, são chamados a um exercício de estranhamento, passam a perceber o patrimônio sob uma nova perspectiva. Esse novo olhar é imbuído de subjetividades, em que o observador sente-se um estrangeiro em sua própria cidade. Através desse novo olhar, os bens patrimoniais são ressignificados e, além disso, o observador começa a se reconhecer no Patrimônio, por perceber ali parte de sua história, de sua identidade.

"Com certeza... É, o Frei Ambrósio é...Como que eu posso Ihe dizer...É uma escola antiga e que é muito respeitada, são 114 anos de história... E, pra mim é algo que eu gosto muito, porque até a minha avó estudou aqui, então se torna algo muito importante pra mim". (Aluno 2)

O conhecimento dos bens patrimoniais pela comunidade é muito importante no processo de Educação Patrimonial, afinal é a comunidade que elege o que é ou não o seu Patrimônio. Nesse sentido, Braga (2011, p. 19) pondera que "a Educação 
Patrimonial é tema de fundamental importância para que as comunidades sejam as grandes protagonistas de seus patrimônios e para que elas possam indicar os rumos que as futuras políticas preservacionistas devem tomar".

Nesta perspectiva, os alunos mostraram-se conhecedores dos Bens Patrimoniais Edificados em Santarém. Na fala a seguir, é possível perceber esta concepção:

\begin{abstract}
"Tem o museu, o casarão que foi derrubado...o que mais... A igreja da matriz...Tem o patrimônio... O que mais...Tipo assim: na revista que a vovó tem lá em casa, que a vovó trabalha na prefeitura, ela tem sobre uns patrimônios de Santarém...E aparece a igreja lá da Vila Franca, que é uma das igrejas bem antigas mesmo, que tem uma imagem tipo de Jesus no caixão, assim, tipo realista...Bacana. Eu não vou muito nesses lugares, só costumo muito viajar para fora. Aqui em Santarém eu só fui no Casarão quando ainda tava de pé, no Museu aqui em baixo que é o Dica Frazão e no Museu aqui na Praça (se referindo ao Centro Cultural João Fona, Museu de Santarém)" (Aluno 1).
\end{abstract}

$\mathrm{Na}$ narrativa acima é possível perceber o conhecimento do aluno sobre alguns Patrimônios Edificados localizados no Centro Histórico de Santarém e, também, de uma igreja bem afastada da zona urbana da cidade. Inclusive, cita o Casarão Tapajônico que teve sua parte interna toda destruída há pouco tempo, o que foi explanado no primeiro capítulo desta dissertação. Isto demonstra o quanto é importante o conhecimento e a proximidade entre o sujeito histórico e o seu meio social.

Mostrando-se conhecedor dos bens patrimoniais locais, o Aluno 2 citou também o Museu Dica Frazão, o Centro Cultural João Fona, mais conhecido como Museu de Santarém, e a antiga Padaria Lucy que teve sua parte interna toda destruída, ficando apenas a fachada de pé, mostrada no primeiro capítulo deste trabalho.

"Tem o Museu Dica Frazão né...Tem... É o Museu daqui da frente da cidade...É, tem a padaria... Esqueci o nome daquela padaria... Mas que já foi até demolido...Foi essa, conheço esses três" (Aluno 2).

O Centro Cultural João Fona, mais conhecido por Museu de Santarém também foi lembrado pelo Aluno 3, bem como a Igreja Matriz de Nossa Senhora da Conceição. Este acrescentou, ainda, o prédio da Prefeitura Municipal e a Praça do Mirante, anexa à Escola Frei Ambrósio, de onde se tem uma visão privilegiada para o encontro das águas dos rios Amazonas e Tapajós (Figura 53). 
"Alguns, por exemplo, que tem: o Museu, a Prefeitura, o Mirante, praticamente que é o Barão do Tapajós, um lugar muito bem visitado pelos turistas e a Catedral de Nossa Senhora da Conceição" (Aluno 3).

A Casa da Cultura de Santarém, o Centro Cultural João Fona e a Prefeitura Municipal foram lembradas pelo Aluno 4 e, assim como Aluno 3, frisou o quanto a Praça do Mirante é visitada pelos turistas que na cidade chegam.

"Sim o Museu (se referindo ao Centro Cultural João Fona, Museu de Santarém), a Casa da Cultura, a Prefeitura e o Mirante que é bem visitado pelos turistas" (Aluno 4).

O resultado dessa pergunta é animador e, ao mesmo tempo, desafiador. Primeiro, porque fica evidente que os alunos conhecem alguns patrimônios edificados de sua cidade. Talvez, porque esses Patrimônios, citados pela maioria deles, já tenham sido visitados em aulas de campo ou por ser palco de algum evento comemorativo realizado pela Escola.

A Igreja Matriz de Nossa Senhora da Conceição é cenário todos os anos da celebração de aniversário da escola. Isso é um fator importante ao se questionar porque a maioria dos alunos a lembrou enquanto Patrimônio Edificado. O Centro Cultural João Fona, mais conhecido como Museu de Santarém, é um espaço turístico muito conhecido da cidade e, através das entrevistas realizadas com os alunos e professores, ficou claro que esse patrimônio edificado é muito visitado pelos alunos da Escola Frei Ambrósio. Dessa forma, foi um dos mais lembrados por eles. Outro patrimônio edificado, próximo a Escola, que foi mencionado pelos alunos é o Museu Dica Frazão, onde eles também visitam com frequência.

A Escola Frei Ambrósio foi reverenciada pelo Aluno 8 como seu Patrimônio. Assim, percebe-se uma aproximação entre o Bem Patrimonial, a ideia de pertencimento e, por conseguinte, o seu cuidado.

"Sim. A igreja aqui...Eu esqueci o nome dela [o pesquisador pergunta se é a Igreja Matriz de Santarém e o depoente afirma que sim]. É essa mesma. 0 Museu João Fona" (Aluno 5).

"Sim, Museu João Fona e Igreja Matriz de Nossa Senhora da Conceição... [o pesquisador pergunta se o depoente quer citar mais algum] Tem, mas não lembro" (Aluno 7).

“A Igreja Matriz de Santarém, a Escola Frei Ambrósio" (Aluno 8).

“Igreja Matriz” (aluno 9). 
"Museu João Fona" (aluno 10).

Desse modo, fica evidente que o Patrimônio, de fato, é aquele que é eleito pela comunidade, onde de alguma forma fez ou faz parte de sua história, sua memória, tem ligação e importância para quem os elege. Os patrimônios ora apresentados pelos alunos são aqueles que têm grande visibilidade na ambiência urbana, devido ao seu valor para comunidade local, sua historicidade e, por vezes, devido ao seu pioneirismo. A exemplo disso, alguns alunos citam a Escola Frei Ambrósio - primeira escola pública implantada na cidade.

Os alunos poderiam ter elegido muitos outros Patrimônios como sendo representativos de sua história, memória e identidade, porém destacaram os que eles têm familiaridade, vínculo, apreço e, acima de tudo, conhecimento. Dessa forma, Prats apud Bomfim (2009, p. 129) sustenta que "o Patrimônio é, portanto, uma construção social, um processo simbólico de legitimação social e cultural, baseado na seleção e ativação de determinados referentes que permitem representar uma determinada identidade".

Se a comunidade já tem consciência e elege seu Patrimônio é porque tem algum conhecimento do que é ser cidadão e viver sua cidadania. Para muitos, ser cidadão é ter o direito de votar, porém quem já teve alguma experiência política no bairro, escola, igreja, sindicato, entre outros, sabe que o ato de votar, por si só, não garante nenhuma cidadania se não vier junto de determinadas condições de nível econômico, político, social e cultural (CERQUIER-MANZINI, 2013).

Nessa perspectiva "ser cidadão significa ter direitos e deveres, ser súdito e ser soberano" (CERQUIER-MANZINI, 2013, p. 11). Esta autora afirma, ainda, que "só existe cidadania se houver a prática da reivindicação, da apropriação de espaços, da pugna para fazer valer os direitos do cidadão [...], cidadania é o próprio direito à vida no sentido pleno" (p. 13-14).

Nesse contexto, a Educação Patrimonial é um importante meio para o desenvolvimento da cidadania, pois através dela os seres humanos têm acesso à sua história e memória, ou seja, cria condições para que o seres humanos tenham acesso a um direito - sua história - e, ao mesmo tempo, os conscientizam sobre a importância de sua preservação - um dever de todos. Ademais, os patrimônios culturais de uma comunidade expressam seus aspectos sinaléticos - aqueles que singularizam os grupos sociais, os distinguem de outros grupos e povos. $O$ 
conhecimento das singularidades (as identidades) de grupos sociais específicos é passo importante para construção do respeito entre culturas, pois o ser humano só aprende a respeitar e amar aquilo que conhece.

Em Hall (2005), a identidade aparece sob três perspectivas: o sujeito do iluminismo que passou para o sujeito sociológico e depois para o sujeito pósmoderno. O primeiro com uma identidade fixa, centrado e unificado, passando a assumir a dimensão do sujeito sociológico mediado entre o eu e a sociedade e, depois, ao sujeito pós-moderno em que, para o teórico, não existe mais uma única identidade, mas várias, múltiplas, fragmentadas, inacabadas, contraditórias, não resolvidas e em constante deslocamento. Para Hall (2005. p. 13), "a identidade plenamente unificada, completa, segura e coerente é uma fantasia [...], somos confrontados por uma multiplicidade desconcertante e cambiante de identidades possíveis".

Os apontamentos de Hall se aproximam das ideias de Bauman (2005), na obra Identidade, onde o teórico exemplifica a questão das identidades que o indivíduo assume no seu cotidiano ao se referir a Agnes Heller, sua colega de trabalho, que, em certa ocasião, queixou-se a ele dizendo que estava sobrecarregada de identidades, ao afirmar que era "mulher, húngara, judia, norteamericana e filósofa". Em outra passagem do livro, Bauman afirma que

\footnotetext{
Estamos agora passando da fase 'sólida' da modernidade para a fase 'fluída'. E os 'fluidos' são assim chamados porque não conseguem manter a forma por muito tempo e, a menos que sejamos derramados num recipiente apertado, continuam mudando de forma sob a influência até mesmo das menores forças. Num ambiente fluido, não há como saber se o que nos espera é uma enchente ou uma seca - é melhor estar preparado para as duas possibilidades (BAUMAN, 2005, p. 57).
}

Bauman continua seu argumento exemplificando a fluidez, a efemeridade e mobilidade, algumas das características da modernidade líquida: "autoridades hoje respeitadas amanhã serão ridicularizadas, ignoradas ou desprezadas; celebridades serão esquecidas [...], poderes indestrutíveis se enfraquecerão e se dissiparão, importantes organizações [...] serão engolidas por outras" (BAUMAN, 2005, p. 58). Para esse autor, a construção da identidade é constituída de experimentos infindáveis. À contrapelo da efemeridade do mundo moderno, dentro do contexto da globalização que vivemos em nossa contemporaneidade, a Educação Patrimonial 
surge como uma possibilidade de preservar os legados de outrora para que as sociedade não percam suas referências identitárias.

Para Tolentino (2013, p. 7), "a identidade é o sentimento de um indivíduo ou grupo em pertencer a uma determinada região, prática social, ideia ou sistema de valores [...], as identidades expressam uma postura e ação de afirmação étnica, local, ideológica [...]".

Já Delgado (2010, p. 49) afirma que:

Os lugares da memória e os objetos biográficos podem ser considerados como esteios das identidades sociais, como monumentos que têm, por assim dizer, a função de evitar que o presente se transforme num processo contínuo, desprendido do passado e descomprometido com o futuro.

A referida autora afirma ainda que "a identidade, além de seus aspectos estritamente individuais, apresenta dimensão coletiva, que se refere à integração do homem como sujeito do processo de construção da história" (DELGADO, 2010, p. 51).

A Educação Patrimonial é a educação para a cidadania, para a afirmação das identidades, tanto individuais como coletivas e compreende também a educação para o olhar dos sujeitos históricos. A observação constitui-se na primeira etapa da metodologia da Educação Patrimonial destacada por Horta et al. (1999), compreendendo exercícios de percepção visual e simbólica. Dessa forma, ao visualizarem os Patrimônios Edificados de sua cidade, os alunos estão atentos, indagadores, afim de "olhar bem". Eles demonstraram o olhar cunhado por Cardoso (1998), quando citaram o Casarão Tapajônico e a antiga Padaria Lucy, pois, para muitos, esses Patrimônios são apenas vistos e nada mais. Nessa perspectiva, o olhar representa o sentido de cuidar, zelar, guardar tanto de um indivíduo, como um bem patrimonial (BOSI, 1998)

Existem muitos outros Patrimônios Edificados no Centro Histórico de Santarém, no entorno e afastados do centro que poderiam ser lembrados pelos alunos, mas não o foram. Talvez, justamente pela ausência de ações mais eficazes de Educação Patrimonial que divulguem esses Patrimônios, que levem esses alunos a conhecerem a teoria e, na prática, cada um desses bens patrimoniais e, assim, estabelecer uma relação mais próxima com eles.

Identificados os Patrimônios Edificados em Santarém e reconhecendo que estes estão contidos no Patrimônio Cultural assumido por Tolentino (2013, p. 7) 
como "o conjunto de manifestações, realizações e representações de um povo", o mesmo autor postula que ele [o Patrimônio] se faz presente em todos os lugares e atividades: ruas, casas, danças, música, artes, museus, escolas, igrejas, praças; nos modos de falar, fazer, criar e recriar, trabalhar, nos livros, poesia, cultos...; ele faz parte do cotidiano das pessoas, está na memória, forma a identidade nossa e dos outros, é ele que nos faz ser o que somos, individualmente ou em grupo.

Pudemos perceber, através das entrevistas, o conhecimento que os alunos têm do patrimônio histórico e cultural da cidade de Santarém e o significado desse dos bens patrimoniais para eles. Feito isso, indagamos os alunos sobre a importância do Patrimônio de Santarém para os moradores da cidade e para os turistas. Vejamos:

"É importante porque pras pessoas que vem de fora, elas vem pra conhecer um pouco a cidade, no museu, nesses pontos turísticos, eles podem saber como é a cidade, conhecer um pouco" (Aluno 1).

Nesta fala é possível perceber que, através dos Patrimônios Edificados, a cidade se mostra tanto para o morador como para quem vem visita-la. Através de seus bens culturais, podem-se descobrir informações pitorescas e mais aprofundadas sobre sua história e cultura. A visitação aos museus e pontos turísticos é importante passo para isso.

A perspectiva de cidade para Villaschi (2012, p. 61) demonstra o quanto ela é complexa, rica, simbólica, viva, movimento, ressignificação e descoberta. A cidade, como expressão cultural orgânica, é o artefato humano mais
complexo e, por isso, é produto sempre inacabado do sistema de relações
entre usuário e espaço, ambos em constante movimento e incessante
processo de transformação.

As respostas dos Alunos identificam a importância dos bens patrimoniais como aglutinadores da história da cidade - a cidade do outrora e do presente, e as transformações pela qual ela passou no percurso dos tempos. Os Patrimônios Edificados são construções sociais representativas da história, cultura, memória e identidade dos grupos que os elegem. Para Meneses (2012, p. 27), “a ideia de Patrimônio deve nos dar a dimensão da consistência inseparável da cultura e de sua construção social, da memória e de sua ética, da política e das escolhas coletivas". Dessa forma, para este teórico, "não se pode, assim, dimensionar o Patrimônio de 
uma sociedade sem considerar as suas escolhas, a construção seletiva da memória social" (MENESES, 2012, p. 27).

"A importância deles é muito grande, porque é pra nós moradores e os turistas... É saberem e aprenderem a nossa história, saberem como foi feito, como era a nossa cidade era antigamente, que patrimônio são coisas antigas, até" (Aluno 2).

Além da história local, a cultura da cidade, como importante vetor de atração para os turistas, foi destacado nas falas dos Alunos 3 e 4 . A cultura será entendida aqui, conforme a acepção de Bosi (1992, p. 309), como uma "herança de valores e objetos compartilhada por um grupo humano relativamente coeso". Ou ainda, o que afirma a Superintendência do IPHAN na Paraíba ( 2011, p. 55): "todo complexo que inclui conhecimentos, crenças, arte, moral, leis, costumes ou qualquer outra capacidade ou hábitos adquiridos pelo homem como membro de uma sociedade".

"A importância deles é conhecer um pouco mais sobre a história Santarena, um pouco mais sobre a nossa cultura, a nossa história" (Aluno 3).

"A importância é que eles servem para contar um pouco da história e a cultura santarena" (Aluno 4).

Percebe-se, através das falas dos depoentes, que a história da cidade, cultura e Patrimônio são temas essenciais para moradores e turistas. Dessa forma, mais uma vez referendam a importância da Educação Patrimonial neste processo de construção do conhecimento.

Para o Aluno 6, os Patrimônios servem para referenciar a cidade, eles simbolizam o que ficou no passado, servindo também de referência no presente. Para saber sobre a cidade, é necessário conhecer sua história e as "coisas antigas" que compõem esse enredo.

"Qual a importância? Acredito que a importância do patrimônio, elas são pra referenciar a cidade, tipo aquilo que foi construído antes, atrás, acredito que isso vai simbolizar a nossa cidade, isso vai se caracterizar a nossa cidade, vem trazer o que é realmente a nossa cidade, de que foi ela construída, de que foi ela feita, quais foram os benefícios, entendeu? Pra nossa geração agora! Atual, Acredito que os, para eles conhecerem verdadeiramente a nossa cidade, eles tem que procuram coisas antigas né? Pra poder saber como era, como é que tá agora. Então, eles não vão procurar agora nas coisas atuais, não! Eles vão procuram primeiro nas coisas antigas, pra poder chegar atualizados. Acredito que seja isso" (Aluno 6). 
A cidade é vista neste estudo como um tecido vivo, palco onde relações sociais se estabelecem, imbricadas de simbologia, estranhamento, diversidade, contrastes, saberes, construção e reconstrução, ressignificação, histórias, memórias e identidades.

A cidade, para Pesavento (2012), é o locus onde se produzem as diferenças, onde há o estímulo da diversidade, expõe o contraste e exclusão, onde se estabelecem as práticas sociais e relações entre grupos. Ela está em constante transformação. Sendo assim, "o modo como a cidade se transforma é essencial para a construção de uma identidade contemporânea e para a manutenção de sua memória" (LAER, 2008, p. 25).

Pesavento (2012, p. 409) infere, ainda, que a "paisagem, monumento, ícone, ruína, história, literatura, estilo arquitetônico [...], os mitos, as lendas urbanas, as modinhas, as histórias extraordinárias [...] corroboram para dar uma cor, um éthos, um perfil à cidade". Esta autora sustenta ainda que:

Uma cidade é, sem dúvida, antes de tudo, uma materialidade de espaços construídos e vazios, assim como é um tecido de relações sociais, mas o que importa, na produção do seu imaginário social, é atribuição de sentido, que Ihe é dado, de forma individual e coletiva, pelos indivíduos que nela habitam (PESAVENTO, 1999, p.32).

Para Gastal (2000, p. 35) as cidades são "medusas sedutoras, abrigam a cada ano um maior contingente de moradores, e são, também, cada vez maiores os contingentes de viajantes que optam por elas como destinos turísticos".

A história e cultura de Santarém são categorias que foram elencadas pelos alunos, com forte poder de motivação para os turistas. Sabe-se que a história e cultura da cidade tem sua origem indígena, portuguesa e africana, dessa forma, multicultural, rica e diversificada. A preservação dos bens culturais, dentro do viés da Educação Patrimonial, contribui para deixar viva na memória a história de determinados grupos sociais, uma forma de resistir ao tempo para que o passado possa sempre ser lembrado. Nesse sentido, os patrimônios de Santarém são representações da identidade e memória daquele povo enquanto grupo social amazônida. Nessa perspectiva, Pesavento (2012, p. 409) infere que o Patrimônio é "aquilo que faz os habitantes tornarem 'seus' um pedaço ou lugar da cidade, fazendo-os visíveis ao coração ou os relegando à invisibilidade”. Esta autora afirma, ainda, que o Patrimônio "remete ao pertencimento, à identidade, à apropriação 
simbólica, ao reconhecimento, ao controle do tempo, ao desejo de preservação e guarda como algo que baliza um pertencimento" (PESAVENTO, 2012, p. 402).

Para Lynch, "cada cidadão tem vastas associações com alguma parte da sua cidade, e a imagem de cada um está impregnada de lembranças e significados" (LYNCH, 2010, p. 1).

"Ah, os patrimônios edificados, tem...É, tem o Museu né, o João Fona, o Dica Frazão, tem também...A Igreja, essa igreja Matriz né, um dos patrimônios e tem mais dois que eu não tô lembrado" (Aluno 6).

Em crônica publicada em 2006, Pinto destaca o que consiste em ser Amazônida: "Amazônidas, somos filhos da água e da floresta. Temos $12 \%$ da água doce superficial da Terra e um terço de suas florestas tropicais remanescentes, que são as mais ricas em biodiversidade desta nossa Gaia".

Descendentes de índios com mistura de portugueses e negros, povos da floresta, chamados de mocorongos por terem nascido em Santarém do Pará, recebem essa denominação não em sentido pejorativo, pelo contrário, como afirmação de identidade, um grupo social pertencente a esta cidade.

Em Pinto (2006), encontra-se uma passagem que corrobora para o debate em tela:

E o que é ser amazônida? Foi o que um valente advogado paranaense (futuro presidente da Funai) me perguntou em 1990, quando participávamos, em Paris, da sessão do Tribunal Permanente dos Povos dedicada à Amazônia. "Somos todos brasileiros. Não existe esse negócio de amazônida", insistiu o advogado, que se aproximou de mim, aflito, quando usei essa expressão na minha exposição aos membros do tribunal. Ele temia que eu estivesse sugerindo (ou propondo diretamente) que éramos um país dentro do país.

E não somos mesmo? Somos, sim. Primeiro porque somos o Brasil tardio, a última região que se tornou brasileira no Império (e, ao tentar se integrar, durante a Cabanagem, foi reprimida brutalmente pelo governo do Rio de Janeiro). E que permaneceu à parte até o advento da República, como se fosse um anexo nacional. E, segundo, porque somos uma região dominada pela floresta num país de bandeirantes, quase sinônimo de predador de gente e predador de mata. Somos a última possibilidade de civilização florestal. Não só no país, é bom acrescentar: na história do gênero humano.

Queremos o Brasil aqui conosco, partilhando nossa rica história, tão ou mais exuberante do que a de qualquer outra região do país. Mas queremos que os brasileiros, reconhecendo nossa condição de amazônidas, queiram ser amazônidas como nós, ao invés de combater esse nosso ethos. Prometemos ser também bons brasileiros, fazendo a fusão que criará um novo e glorioso capítulo na história da humanidade, sem rios violentados e árvores desbastadas. Um Brasil verdadeiramente amazônida e uma Amazônia genuinamente brasileira.

Conhecida e reconhecida pelos alunos e professores como Patrimônio Edificado, a Escola Frei Ambrósio é um desses símbolos de identidades, lugar de 
memória e pertencimento, onde seus alunos passam boa parte de seu tempo construindo sua história, cidadania, a fim de se tornarem sujeitos históricos. Sobre a Escola ser um Patrimônio, os alunos assim se manifestaram:

"É um patrimônio, por causa que foi a primeira escola de Santarém, então é um patrimônio....Histórico" (Aluno 1).

Na perspectiva de Patrimônio elencada pelo Aluno 1, fica evidente a relação entre Patrimônio e o tempo de existência da Escola, mais relacionada com a questão do pioneirismo.

O tempo de contribuição para o ensino foi evidenciado na fala do Aluno 2, pois este tem o conhecimento de que a Escola é a mais antiga da cidade e, por esse motivo, de acordo com o olhar desse aluno, deve ser respeitada. Em 2014, a Escola Frei Ambrósio, completou um trajetória de 114 anos, o que lhe confere, de acordo com o olhar dos alunos, a adjetivação de respeitada.

Outro dado importante colhido nesta entrevista é o fato de saber que a avó do aluno também estudou na Escola. Gonçalves (2005, p. 214), corrobora para o debate ao situar que "um Patrimônio não depende apenas da vontade e decisão políticas de uma agência de Estado. Nem depende exclusivamente de uma atividade consistente e deliberada de indivíduos ou grupos. Os objetos que compõem um Patrimônio precisam encontrar 'ressonância' junto a seu público".

"Com certeza... É, o Frei Ambrósio é...Como que eu posso Ihe dizer...É uma escola antiga e que é muito respeitada, são 114 anos de história... E, pra mim é algo que eu gosto muito, porque até a minha avó estudou aqui, então se torna algo muito importante pra mim" (Aluno 2).

Conforme o Aluno 3, existem outras qualidades na Escola e adiciona ainda o fato da localização privilegiada e do tempo de existência da mesma a serviço da educação na cidade.

"Sim, pois, além de tudo ela...Além de ficar focada no coração de Santarém, ela é uma das escolas mais antigas que está em funcionamento" (Aluno 3).

Bem próxima à perspectiva do Aluno 3, confidenciou o Aluno 4 identificando a Escola como Patrimônio que está a serviço da sociedade local, e ser uma das mais antigas em funcionamento. Nesse sentido, o Patrimônio está a serviço da coletividade. 
"Sim, porque é um patrimônio que serve a sociedade santarena e é uma das escolas mais antigas que ainda funciona" (Aluno 4).

Na mesma perspectiva, o Aluno 5 evidencia a Escola como propulsora do ensino local, educando e formando.

"Sim, eu considero a Escola Frei Ambrósio um patrimônio pelo fato de ser uma das escolas mais antigas de Santarém, e por ser mais de um século educando jovens, formando...E é isso!" (Aluno 5).

O Aluno 6 destaca a importância da Escola enquanto bem patrimonial com um tempo considerável de existência em benefício da educação na cidade, onde gerações inteiras de famílias e amigos passaram pela Escola, criando, desta forma, laços de pertencimento e identificação passados de uma geração a outra. Observação pertinente ao debate faz Meneses (2012, p. 25), quando diz "quem guardou o bem, quem preservou, quem conservou, quem memorizou, foi a comunidade. Antes das leis [...], antes dos instrumentos de interpretação, a sociedade não perdeu o que não queria perder".

"Sim, considero, porque foi à primeira escola estadual que foi fundada aqui
em Santarém, então, ou seja, já faz muito tempo, aqui né, faz...Não me
lembro a idade da nossa escola...(O pesquisador informa que são 114 anos,
o que é confirmado pela depoente). São 114 anos de educação, que a muito
tempo já passaram por muitas gerações, que agora a gente pode ver, que a
atuação de alunos que seus pais, seus tios, seus avós, seus amigos né?
Seus irmãos, estudaram aqui, ou seja, esse foi um patrimônio que a nossa
cidade constituiu e agora a nossa geração de 2014 está utilizando" (Aluno 6).

As respostas dos Alunos 7, 8 e 10 estão em consonância ao reconhecerem a Escola Frei Ambrósio como a primeira escola fundada em Santarém ou a "quase mais velha" ou antiga, associando o Patrimônio à antiguidade. Para Bastos (2012), o Patrimônio constitui-se em importante referencial cultural para o grupo social que o elege, mantém e dele se apropria, sendo portador de memória e identidade. Os monumentos, por exemplo, são significados e ressignificados por práticas discursivas, ou seja, são marcados por sentidos múltiplos que expressam as referências identitárias de um povo, para que tais bens culturais e o passado que eles representam não caiam no limbo do esquecimento, daí a necessidade de preservá-los, tornando sensível sua lembrança. 
"Sim, porque ela é a primeira escola, acho que foi uma das primeiras escolas criadas aqui em Santarém” (Aluno 7).

"Sim, porque é a escola quase mais velha de Santarém e é um patrimônio" (Aluno 8).

"Considero, porque é uma escola antiga, tem 114 anos. E ela tem muitos alunos antigos que até já se formaram em faculdades, etc" (Aluno 10).

O Patrimônio Edificado, que faz parte do Patrimônio Cultural, é visto pelos alunos através da Escola em que estudam como portadores de identidade, memória, como evidenciados no artigo 216 da Constituição Federal de 1988: os bens de natureza material e imaterial, constituídos em conjunto ou individualmente, portadores e referência à identidade, à ação, à memória dos diferentes grupos formadores da sociedade brasileira.

Em Couche (1999, p. 182), encontra-se uma definição para identidade:

\begin{abstract}
A identidade é uma construção que se elabora em uma relação que opõe um grupo aos outros grupos com os quais está em contato [...]. A identidade é um modo de categorização utilizado pelos grupos para organizar suas trocas. Também para definir a identidade de um grupo, o importante não é inventariar seus traços culturais distintivos, mas localizar aqueles que são utilizados pelos membros do grupo para afirmar e manter uma distinção cultural.
\end{abstract}

Dessa forma, ao elegerem a Escola Frei Ambrósio como Patrimônio, seus alunos estão demarcando um espaço do qual fazem parte, se identificam, tem estima, zelo, constituem laços de pertencimento.

Ao reconhecerem a Escola como importante bem patrimonial, os alunos estão chancelando que a mesma é um espaço de construção do conhecimento, da história, cultura, memória, identidade e cidadania.

Pode-se dizer que, através das afirmativas dos alunos, eles têm conhecimento e reconhecimento de que a Escola onde estudam é um Patrimônio importante para Santarém, pois tem consciência de seu valor histórico, seu valor enquanto escola mais antiga da cidade e sua localização privilegiada.

Seu papel na formação educacional de gerações inteiras, conforme destacado na fala de alguns alunos, refletem a confiança, o respeito e a importância dada a essa Escola como instituição de ensino.

A maioria dos alunos sabe quantos anos a Escola tem de fundação e um conhecimento básico sobre as etapas que passou até seu endereço definitivo/atual. 
Isso se justifica pelos projetos e ações desenvolvidos pelos professores e direção no que tange à história e importância da Escola para Santarém. Os alunos sabem que a escola é deles, tem apreço e pertencimento a ela.

A construção do sujeito histórico, através de uma educação de qualidade postulada como critico-reflexiva em Freire (2011), tem de estar em consonância com uma formação cidadã. Assim, fez-se necessário saber o que os alunos pensam sobre cidadania:

"Pra mim cidadania é o exercício de deveres... Direitos e deveres do cidadão, é que ele, como você disse, que ele possa ir a algum lugar com liberdade, se respeitando, claro" (Aluno 1).

A compreensão de cidadania para o Aluno 1 está associada ao exercício de direitos e deveres do cidadão, é, nesse aspecto, ter o direito de ir e vir; ter liberdade para deslocar-se para onde quiser. Em Pinsky (2003, p. 9), ser cidadão

É ter direito à vida, à liberdade, à propriedade, à igualdade perante a lei: é, em resumo, ter direitos civis. É também participar no destino da sociedade, votar, ser votado, ter direitos políticos. Os direitos civis e políticos não asseguram a democracia sem os direitos sociais, aqueles que garantem a participação do indivíduo na riqueza coletiva: o direito à educação, ao trabalho, ao salário justo, à saúde, a uma velhice tranquila. Exercer a cidadania plena é ter direitos civis, políticos e sociais.

A cidadania pressupõe ter direito de ser cidadão, exercer seus direitos e deveres.

"Cidadania pra mim é o direito do cidadão exercer seus direitos e deveres" (Aluno 4).

Quando o Aluno 6 infere que a cidadania faz referência ao povo, lembrou-se dos apontamentos de Chaui apud Meksenas (2002, p. 21): "Povo como uma vontade universal, definido por lei, assim, Cidadão. Por outro lado, temos o povo como uma particularidade social: os pobres, ignorantes, violentos [...], que necessitam de solidariedade e educação".

"Cidadania? Acredito que seja o povo, eu acho, que venha se referir aos cidadãos da nossa cidade, as pessoas, acredito que seja isso" (Aluno 6).

O indivíduo que tem consciência de seus direitos, deveres e obrigações, que cobra por melhores condições sociais e culturais, comprometido com o coletivo, com a melhor distribuição de renda entre as pessoas, com a equidade, sujeito de sua história e ávido por justiça social, é representado na fala do Aluno 10. 
"É uma pessoa cidadã né..." (Aluno 10).

O entendimento de cidadania dos alunos, portanto, está alinhado ao que postula Pinsky (2003) e, também, ao que indica Ferreira (2004, p. 51):

Cidadania implica o reconhecimento e a concretização dos direitos civis, políticos e sociais, cidadania requer a prática de reivindicação, com a ciência de que o interessado pode ser o agente destes direitos, o exercício da cidadania requer o conhecimento dos direitos e também dos deveres, cidadania implica sentimento comunitário, em processos de inclusão, a prática da cidadania apresenta-se como instrumento indispensável para a construção de uma sociedade mais justa e igualitária.

A cidadania tem na educação, por conseguinte, seu principal instrumento de promoção. Bobbio apud Gentilli (2005) assevera que a democracia moderna, tão importante para a cidadania é entendida como "sociedade dos cidadãos", noção que diz respeito à ampliação dos direitos civis, políticos e sociais. Entende-se que não há cidadania sem educação, pois a ampliação dos direitos civis, políticos e sociais passam pelo crivo de uma educação que preza pelo crescimento humano, pelo respeito à diversidade cultural e as identidades. A Educação Patrimonial constitui esse conceito maior de educação para a cidadania, por incluir em suas práticas pedagógicas o conhecimento e respeito aos bens culturais que representam as identidades culturais, tornando sensível a presença destas.

A cidadania é vivenciada no cotidiano dos alunos da Escola Frei Ambrósio, através da Educação, do esclarecimento de sua definição, através dos projetos desenvolvidos pelos professores junto aos alunos e que envolvem toda a comunidade escolar e, por vezes, a sociedade local.

Sobre o assunto cidadania, o pesquisador questionou ao professor $\mathrm{C}$ se ele notou mudanças no comportamento e postura dos alunos. Vejamos sua percepção:

"Com certeza absoluta, as mudanças são visíveis nos alunos que estão envolvidos. Nós dentro do Sol trabalhamos com teatro também, então todos os sábados esses meninos recebem aula de teatro, a gente tem um grupo que é dessa associação que dão aula de teatro voluntariamente, tanto é que nós temos o grupo de teatro na escola. O espetáculo que nós é, elencamos se chama "O alto da barca do fisco", onde se trabalha a questão da corrupção né, ela é uma peça baseada no Ariano Suassuna e no Gil Vicente, porque ela é uma sátira né, onde meninos brincando, porque ela é muito divertida é, falam justamente sobre, é, a corrupção como um todo, eram políticos que iam dentro de um avião para Brasília e o avião explode e morre todo mundo, então todas as almas vão pro purgatório e vão ser julgadas por São Miguel pra ver quem é que vai pro céu ou quem vai pro inferno a partir do que fizeram na terra, então é muito bacana, então a gente trabalha o teatro de uma forma educativa né, onde também dentro do teatro nós trabalhamos a 
questão, por exemplo, dentro do museu com o Laurimar Leal, é um trabalho feito intensivamente que nesse momento tá parado devido o museu está estagnado, em reforma, então nós temos que tá trabalhando dentro, a gente costuma dizer pros alunos que o Laurimar Leal, ele é o guardião dessa cidade, não tem coisa melhor do que chegar no museu e encontrar o Laurimar, que tá cego, mas que enxerga mais do que a gente né, então é com ele...É com o Laurimar que eles aprendem a questão cultural da cidade, as lendas, a questão do patrimônio, as histórias, sabe, então é uma verdadeira aula com ele, então a gente faz, a gente tem essa parte dentro do projeto...Eu esqueci de falar do Programa Mais Educação, que dentro do Mais Educação que também eu coordeno né, nós também trabalhamos, por exemplo, nós temos um dos macro campos que é direitos humanos, lá nós trabalhamos música, que dentro da música eles aprendem o coral, é...Flautas, percussão, nós temos arte marcial que é o judô, karatê, nós temos é... O estudo e leitura onde eles também passam por essa parte histórica, geográfica e temos direitos humanos que é onde eles trabalham justamente a questão da cidadania, então, também os meninos, eles fazem visitas conosco ao museu, tanto o museu João Fona, quanto o museu de Arte Sacra, por exemplo, e de alguns lugares dentro da cidade que é a questão turística também, seja o zoológico, seja em exposições que o Sesc faz, nós levamos eles, então o Mais Educação também acaba auxiliando nessa questão da educação patrimonial.

O Mais Educação, ele é voltado pra alunos do fundamental, de $5^{a}$ a $8^{a}$ séries, mas os alunos da escola são convidados a estarem, tanto que nós temos lá alguns alunos que são do ensino médio, o Projeto Sol Cidadão não, ele é aberto, qualquer aluno dessa escola faz parte dele e realmente nosso público lá é bem diversificado, são alunos que vão desde a $5^{a}$ série até o $3^{\circ}$ ano no caso".

Outro importante assunto necessário para o delineamento desta pesquisa foi saber qual a opinião dos alunos sobre Turismo e a relação deste com a Educação Patrimonial, haja vista ser o Turismo um fenômeno social da contemporaneidade e uma atividade que já é explorada na cidade há muitos anos. Na verdade, a cidade de Santarém é considerada turística tanto pelos moradores, turistas e pelo Ministério do Turismo (MTur).

Turismo é experiência, quer seja para fora de seu local de domicílio ou dentro do seu próprio território como postula o Turista Cidadão. Conforme Quéré e Ogien apud Villaschi (2012, p. 74):

A experiência designa uma travessia que modifica aquele que a realiza. Esta travessia é uma prova, e pode ser ocasionada pela confrontação com um texto (a paisagem), uma obra de arte (o núcleo histórico), um acontecimento (o roteiro sensorial interpretativo) ou uma situação (o compartilhamento de impressões). Implicando a exploração e explicação dos efeitos de interação que a funda, ela é fonte de descobertas sobre o mundo e sobre si, e revela novas possibilidades de compreensão e de interpretação. Ela é produtora não somente de verdade, seja sob a forma de conhecimento ou compreensão, mas também de individualidade (aquela do acontecimento, da situação, do texto ou da obra implicada) e de identidade (aquela de quem faz a experiência e é guiado por ela. 
Baseada nos apontamentos de Marcel Proust, "a verdadeira viagem de descoberta não consiste em buscar novas paisagens, mas em termos um novo olhar". Guimarães (2012) infere que cada experiência vivida permite interpretar a paisagem que nos envolve de diversas formas "propiciando o reconhecimento e a ressignificação de novos cenários demarcados por sensibilidades, intencionalidades e possibilidades que asseguram vivências plenas de significações" (GUIMARÃES, 2012, p. 47). Dessa forma, "a experiência da viagem é de reorganização da própria subjetividade do sujeito. Todo seu repertório se alia ao que ele acaba de ver, olhar, apreender num novo território e essa soma será acrescida ao seu próprio conhecimento" (LEBEDEV, 2010, p. 8).

Compreendemos, portanto, que as viagens sejam sempre experiências de
estranhamento. E podemos mesmo observar que está, talvez, neste efeito de
distanciamento, no sentimento de dépaysement (termo forjado com tanta
felicidade pela língua francesa, cuja significação se aproximaria do nosso
termo "desterro", se tomássemos num registro exclusivamente psicológico e
simbólico) que, de um modo ou de outro, sempre envolve o viajante (que não
se mostra inabalavelmente frívolo), o seu núcleo essencial e sua expressão
mais íntima (CARDOSO, 1998, p. 359).

As experiências, as relações que se estabelecem, as percepções que cada indivíduo vivencia é algo muito pessoal, íntimo que torna a viagem única e subjetiva. Assim, "é o exercício de aguçar a percepção por todos os sentidos e vasculhar os ambientes em seus variados aspectos, o que enriquece a experiência plena dos lugares e a participação sensível do usuário” (VILLASCHI, 2012, p. 69).

"Turismo é a pessoa que vem de fora, de outros lugares, tanto do país, quanto do mundo para visitar uma cidade e um local e ver como funciona, ver a história, ver o passado daquele lugar" (Aluno 1).

Essa narrativa coaduna com o pressuposto de que o Turismo consiste no deslocamento de um indivíduo que vem de fora da cidade, este pode ser brasileiro ou estrangeiro, motivado pela história e o passado do lugar. Pode-se dizer, dessa forma, que sua maneira de entender o Turismo está em convergência com a definição adotada tanto pela Organização Mundial do Turismo (OMT), quanto pelo Ministério do Turismo (MTur).

Turismo é tudo o que as pessoas fazem antes, durante e depois de suas viagens. As relações estabelecidas entre visitantes e visitados. As trocas que são efetivadas. O aluno cita a Praça Mirante do Tapajós, que fica junto a Escola Frei 
Ambrósio, como importante ponto turístico da cidade, onde se estabelecem laços entre os turistas e também os alunos. Villaschi (2012, p. 67) corrobora para o debate ao afirmar que "todo indivíduo estabelece inúmeras relações com os ambientes com os quais convive e a cada um deles correspondem imagens impregnadas de lembranças, valores e significações que lhes atribuem sentido".

"Bom, pra mim turismo é o que as pessoas fazem, é o exercício que as pessoas fazem nas suas viagens, por exemplo, quando eles vem pra cá, os turistas, vem pra cá eles ficam conhecendo a nossa cidade, principalmente quando eles vem, eles vão logo aqui pro Mirante. Eles tiram fotos e fotos, pra eles é legal, porque eles ficam tirando fotos até dos alunos, acho importante isso" (Aluno 2).

O Turismo Cultural é percebido na fala do Aluno 3, quando este faz referência a aspectos da cultura local como fator motivacional para atrair os turistas. Para este Aluno, o Turismo está relacionado principalmente com a cultura.

"O turismo é aquele que envolve mais conhecer um pouco mais sobre a cultura, sobre danças, músicas ou comidas típicas de um local" (Aluno 3).

O MTur (2010, p. 15) postula que "Turismo Cultural compreende as atividades turísticas relacionadas à vivência do conjunto de elementos significativos do patrimônio histórico e cultural e dos eventos culturais, valorizando e promovendo os bens materiais e imateriais da cultura".

Essa perspectiva do órgão oficial está contida no entendimento do Aluno 4 quando este infere que:

"Turismo, é uma forma de fazer, onde se conhece outros tipos de culturas, danças, comidas típicas, praias e novas etnias" (Aluno 4).

O entendimento de Turismo para o Aluno 6 compreende o que autores contemporâneos como Fuster apud Moesch (2000, p. 11) sustentam ao afirmar que "Turismo é, de um lado, conjunto de turistas; do outro, os fenômenos e as relações que esta massa produz em consequência de suas viagens".

"Turismo é a gente... Tem várias relações de turismo né? Tem a gente visitar e tem a gente conhecer, pra mim é assim: visitar e conhecer, ou seja, turismo são relacionados a lugares, lugares que você ainda não foi, ai você se refere a ser tipo turista, acredito que seja isso, turismo. Aqui como a gente pode ver, que vem muita gente pra cá de outros países, de outros lugares, de outras cidades né! Pra cá pra nossa cidade, aqui Santarém, ou seja, acredito que seja isso o turismo" (Aluno 6). 
O Turismo motivado pelos bens culturais é um dos mais realizados na contemporaneidade. Pessoas deslocam-se motivadas por conhecer os centros históricos das cidades onde poderão encontrar igrejas centenárias, museus, espaços culturais, ou motivadas pela gastronomia, religião, modos de vida, etc. Todos esses aspectos contemplam o Turismo Cultural.

"Quando uma pessoa vem de outra cidade conhecer nosso patrimônio da cidade aqui" (Aluno 7).

Associado ao deslocamento é o entendimento que o Aluno 8 tem sobre o Turismo. Quando um indivíduo sai do seu local de origem para outro que lhe é estranho, estabelecendo relações diversas, pode ser caracterizado com fazer turismo, portanto o Aluno 8 tem essa leitura ao afirmar que:

"Turismo é pessoas que vem de fora pra conhecer a nossa cidade" (Aluno 8).

Ao exemplificar seu entendimento sobre Turismo, o Aluno 10 se colocou na condição de turista. Dessa forma para este:

"É a gente andar pelas belezas do Brasil e do mundo, e os turistas que vem de fora pra ver a nossa beleza Santarém. Pra mim é isso" (Aluno 10).

Assim, em relação ao Turismo, os alunos relacionaram o fenômeno e a atividade com o deslocamento que as pessoas realizam para fora de seu local de origem com finalidades diversas: conhecer novas culturas (dança, comida típica, música), estabelecer relações entre visitantes e visitados. Nessa perspectiva, pode se dizer que turismo é experiência, movimento, descoberta, contemplação, conhecimento do novo, daquilo que lhe é estranho, diferente. Porém, o Turismo não pode ser desenvolvido/praticado sem que haja uma Educação Patrimonial. Esta é uma forma importante de sensibilizar a sociedade sobre a importância de seus referenciais identitários, como também torna possível o turista conhecer um pouco mais sobre a história e as múltiplas culturas que os suportes patrimoniais representam.

Acredita-se que com a implantação do Projeto dos Guias Mirins na Escola Frei Ambrósio os alunos terão muito mais conhecimento sobre Turismo e todo o universo que esse fenômeno engloba. 
Ao que se sabe, na literatura nacional, o termo Turista Cidadão foi introduzido no Brasil em 2007 pelas pesquisadoras Suzana Gastal e Marutschka Moesch, portanto, trata-se de um conceito bem recente no país, mas com experiências animadoras nos Estados do Rio Grande do Sul, Ceará, Paraná e no Distrito Federal. Sobre os benefícios que este tipo de Turismo podem proporcionar, Dias e Melo (2014, p. 10) explicam:

\begin{abstract}
A prática do turismo cidadão aprofunda laços com a cultura local, estabelece o sentimento de identidade e pertencimento, por conseguinte, conscientiza da importância e do respeito que se deve ter com a cultura que se encontra em constante construção social. Assim, quando as paisagens cotidianas passam a ter um significado importante para os moradores da cidade que delas usufruem, esses moradores transformam-se em turistas cidadãos.
\end{abstract}

Concorda-se com a citação e acredita-se também que o Turismo Cidadão acontece quando os moradores da cidade assumem-se como cidadãos e passam a cuidar da cidade como uma extensão de suas casas, sensibilizados para as questões sociais e culturais. Para Abreu (2012, p. 3), há turismo cidadão, "desde que este [o morador] consiga desenvolver um processo de estranhamento, perceber locais e costumes já conhecidos sob novas perspectivas, imbuindo-se do olhar de um estrangeiro em sua própria cidade" estabelecendo, dessa forma, novas relações com tais espaços, como preconiza o projeto Guias Mirins ao escolher enquanto rota de exploração o Centro Histórico de Santarém.

Apesar dos alunos não estarem familiarizados com o conceito e significado de Turista Cidadão, isso não quer dizer que eles não praticam o Turismo Cidadão, pois a partir do momento que eles aprendem a valorizar o Patrimônio e são chamados a exercitar um olhar de estranhamento sobre ele e, por conseguinte, se conhecem nele a partir desse novo olhar, estão a praticar o Turismo Cidadão. Com isso, aprendem a valorizar sua história e sua cultura, através de processos de identificação e ressignificação dos bens culturais que os rodeiam.

"Turista Cidadão pra mim é aquele que exerce, investe no turismo e trabalha com ele" (Aluno 3).

"Pra mim o turista cidadão é aquele que dá valor ao turismo e investe no turismo" (Aluno 4). 
É sabido que a Escola Frei Ambrósio desenvolve vários projetos com temas variados e com objetivos múltiplos. Integrar, estimular, desenvolver, questionar, sensibilizar, conhecer, esclarecer, enfim, formar cidadãos para a vida na construção do sujeito histórico. Assim, o último questionamento feito aos alunos indagou se eles já haviam participado de alguma ação, projeto, estudo, oficina sobre Cidadania ou Educação Patrimonial na Escola.

\begin{abstract}
"Eu participei de uma peça do cidadão legal, a morte da cidadania que a gente fez lá na Feira Pan Amazônica. O depoente explica como foi sua participação na peça, foi assim: é por causa que a gente tava meio revoltado por causa desse negócio que fizeram com o casarão, ai fizeram a morte da cidadania... Que é... A gente colocou tipo umas fotos dos pontos turísticos, esse tipo de coisa ai...Fizemos a...Como se, falando pros os alunos das outras escolas que estavam lá...Álvaro Adolfo, Frei Othmar, mostrando que a cidadania e a cultura depende de cada um da cidade" (Aluno 1).
\end{abstract}

O aluno explica que participou de uma peça pelo Projeto Sol Cidadão Legal que ocorreu na Feira Pan Amazônica do Livro no Parque da Cidade, complexo onde as pessoas podem fazer diversas tipos de atividades físicas e onde está localizado o Espaço Pérola, espaço onde ocorre a Feira do Livro.

A peça foi uma ação de repúdio ao que ocorreu com o Casarão Tapajônico que teve destruída toda a parte interna, ficando apenas a fachada. Esse fato foi retratado no primeiro capítulo desta pesquisa.

Através do relato do Aluno, percebe-se que a Escola Frei Ambrósio trabalha com seus alunos questões relacionadas à cidadania e à Educação Patrimonial, mostrando o quão é importante os bens patrimoniais para a história, memória e identidade de um povo.

O aluno consciente, sensibilizado e educado para a cidadania não fica alheio às questões políticas, econômicas e sociais que o rodeia, e a Educação Patrimonial poderá ser um dos caminhos na construção da cidadania.

A "morte da cidadania" foi justamente retratada devido à falta de zelo pelo bem público, fato recorrente há anos na cidade e que deixou muitos alunos indignados.

Como bem colocado pelo Aluno 1, "a cidadania e a cultura depende de cada um da cidade", dessa forma, cada um tem um papel importante na busca de uma sociedade melhor, porém é necessário unir forças para que se consigam ações 
efetivas junto ao poder público e órgãos competentes que cuidam da salvaguarda dos bens patrimoniais.

Os Projetos existem na Escola Frei Ambrósio, porém ainda não contemplam a maioria dos alunos, talvez por falta de uma maior divulgação dentro da Escola ou até falta de interesse de alguns alunos. Contudo, os alunos têm o conhecimento da importância deles, sabem que eles existem, conhecem outros alunos que participam, sabem até o nome dos projetos relatados pelos depoentes

\footnotetext{
"Não, mas aqui no Frei Ambrósio tem o Projeto Sol que eles tratam muito bem sobre isso, tem o Mais Educação, mas não sei se o Mais Educação trata sobre isso. Mas deve tratar" (Aluno 2).

"Não, eu nunca participei disso, mas eu já ouvi várias pessoas participando desse projeto" (Aluno 6).
}

A fala do Aluno a seguir ilustra a questão da participação nos projetos da Escola e das aulas e orientações que fazem parte de seu cotidiano, pois ele assume que nunca participou de nenhuma oficina ou projeto, entretanto, sabe que manter a escola limpa, zelar por ela constitui ações que contribuem para um ambiente melhor, saudável.

"Não, eu nunca participei de oficinas, mas recebi orientações sobre o dever de manter a escola limpa e zelar pelos bens materiais" (Aluno 4).

Através do depoimento do Aluno 10, evidencia-se mais uma vez que os projetos desenvolvidos pela Escola Frei Ambrósio são muito importantes para a formação cidadã, porém ainda precisam estimular ainda mais os alunos a aderirem a eles.

“Já, o projeto Mais Educação” (Aluno 10).

O Projeto Sol Cidadão Legal desenvolve ações de cidadania por meio da Prefeitura Mirim, através de encenações teatrais como a Peça O Alto da Barca do Fisco, visitas a museus, festivais de cultura, entre outros.

São trabalhos que valorizam a cultura local, regional e nacional, destacam a importância da Escola onde eles estudam para a educação e formação cidadã, instigam os alunos para a prática esportiva, para a participação na banda marcial da escola, etc. 
Muitos destes alunos estão praticando Educação Patrimonial, entretanto, não têm essa informação, não está claro para eles que o que eles fazem quando visitam um museu e conversam com os atores, que lá estão, sobre cultura, história, memória, identidade que essa atividade é Educação Patrimonial.

Quando o professor de história, por exemplo, traz um pesquisador da cultura local muito experiente para falar sobre a história de Santarém e falar também dos projetos desenvolvidos por ele na instituição de ensino superior onde trabalha, e depois vão realizar uma caminhada pelo Centro Histórico, esses alunos estão participando de uma atividade de Educação Patrimonial e por extensão se tornam turistas cidadãos quando, a partir dessa atividade ressignificam seu olhar e redimissionam seu modos de perceber a cidade.

Assim, então se pode dizer que os alunos da Escola Frei Ambrósio participam de projetos, ações e estudos sobre cidadania e Educação Patrimonial.

Ouvidos os alunos, partimos agora para a análise sobre o olhar que os professores da Escola Frei Ambrósio construíram sobre o Patrimônio Cultural e a Educação Patrimonial na cidade de Santarém.

\subsection{Com a palavra Os Professores}

A Educação Patrimonial é um processo permanente e sistemático de trabalho educativo, cuja "matéria prima", o cerne, é o Patrimônio Cultural e todas as suas nuances. Para Grunberg (2007, p. 4), o Patrimônio Cultural compreende "todas as manifestações e expressões que a sociedade e os homens criam e que, ao longo dos anos, vão se acumulando com as gerações anteriores [...] cada geração dá a sua contribuição, preservando ou esquecendo essa herança”.

Após saber o que os alunos pensam sobre Educação Patrimonial, chegou a vez dos professores se posicionarem. As respostas foram as seguintes:

\footnotetext{
"Acredito que é conservar e manter o patrimônio, o patrimônio histórico, o patrimônio público, que na verdade são patrimônios nossos né. Nós temos que trabalhar o aluno para que ele possa conservar, pra que ele possa conhecer a importância de preservar esse patrimônio" (Professor A).
}

Através da fala do professor A, percebe-se que a Educação Patrimonial é um instrumento, um meio, muito importante para ser trabalhado com os alunos a fim de pensar na preservação e conservação dos bens patrimoniais. O professor ressalta 
que o Patrimônio é de todos e que o aluno conhecedor desses bens poderá ser disseminador desse conhecimento junto ao meio em que vive.

A Educação Patrimonial para o Professor B é um meio para que o educando tenha consciência da importância do Patrimônio público, seu próprio Patrimônio e a Escola onde estuda.

"Educação Patrimonial é fazer com que o educando possa ter consciência
daquilo que foi construído, daquele patrimônio, principalmente do patrimônio
público, ou pode ser o patrimônio dele mesmo, o patrimônio privado, pode ser
a casa dele, para que ele possa conservar isso... É, manter esse patrimônio,
a própria escola, o próprio prédio da escola é um patrimônio e esse aluno, ele
precisa é...Saber esse patrimônio limpo, esse patrimônio não depredado, ele
precisa...É....Desse esclarecimento, então pra mim educação patrimonial é
fazer com que o educando quando no ambiente escolar possa ter uma
consciência do próprio prédio e dos outros patrimônios que temos pela
cidade, até o seu próprio patrimônio que é a sua casa" (Professor B).

A fala do professor remete ao que postulavam Rodrigo e Mário de Andrade apud Fonseca (1997, p. 139): "o único meio eficaz para criar na população um 'sentido do patrimônio' era a educação popular. Pois, se o contato com os monumentos for integrado ao processo educativo, o impulso de preservá-los será quase instintivo". Para Rodrigo Melo Franco de Andrade apud Fonseca (1997, p. 139) "só do convício com os monumentos e com sua história poderá nascer a estima sincera que eles devem inspirar. Esse sentimento será como o apego às pessoas e às coisas familiares". Ou ainda, Cerqueira (2008, p. 13) "a população diretamente envolvida com os bens culturais patrimonializados precisa conhecê-los e reconhecer-se neles".

O Patrimônio Cultural é muito amplo e não são somente aqueles bens herdados dos nossos antepassados. É também os produzidos no presente, o Patrimônio vivo, os bens imateriais ou intangíveis, apontados pelo Professor C. Tem ainda o Patrimônio Natural.

"Acho que a Educação Patrimonial é a educação voltada pra questão sim do patrimônio da cidade né, acredito que é aquela educação voltada pro que nós temos de valores culturais dentro da nossa cidade, que isso não envolve só o patrimônio material, mas envolve o cuidado com as nossas belezas naturais, com a questão da arte, da música, do teatro né, então essa é a educação voltada para a preservação de, por exemplo, como é que eu posso dizer... Vou dizer aqui, nossa cultura como um todo né. Nós tínhamos aqui em Santarém os bois, por exemplo, os pássaros ai, hoje os meninos nem conhecem esses pássaros que eram na festa junina, porque? Porque não houve uma preocupação em dar continuidade da preservação disso daí". (Professor C) 
Nessa perspectiva Grunberg (2007) infere “[...] culinária, folguedos, expressões artísticas e religiosas..." Tudo faz parte do Patrimônio Cultural. Corroborando para o debate O IPHAN (2012, p. 12) sustenta que o Patrimônio Cultural de um povo "é formado pelo conjunto de saberes, fazeres, expressões, práticas e seus produtos, que remetem à história, à memória e à identidade desse povo".

Com uma concepção bem abrangente se posicionou o Professor D ao afirmar que:

\begin{abstract}
"Bom, a Educação Patrimonial, ela passa por valores, desde a questão do conceito do que é cultura e valorização da questão da cidadania, preservação não só do prédio, mas dos valores específicos que cada cidadão tem que conhecer né, a importância desse prédio, desse conceito patrimônio, a importância do conceito arquitetônico também, porque não é só o prédio em si, mas os valores que são dados desde as pessoas que conviveram na sociedade, que conviveram aqui, neste prédio estudado, eles estão estudando até hoje, tá relacionado à questão da memória, da cidadania, da questão patrimonial, dos valores de cada cidadão". (Professor D)
\end{abstract}

Para este professor a definição de Educação Patrimonial passa por categorias como Cultura e Cidadania, que a preservação vai muito além do espaço edificado. Para Candal apud Bosenbecker (2007, p. 31) "o Patrimônio Cultural é produto da ativação da memória, que selecionando elementos herdados do passado, os inclui na categoria de Patrimônio Cultural seguindo critérios de antiguidade, afeto, sentimento [...]". Bosenbecker (2007, p. 31) afirma que "os lugares patrimoniais ativam o sentido de história no cotidiano" e cita Ecléa Bosi “[...] as lembranças se apoiam nas pedras da cidade [...]".

Tão importante como a Educação formal é a Educação que visa à preservação e conservação do Patrimônio seja ele tangível ou intangível. Ter o conhecimento sobre os bens patrimoniais e sua importância para a história local, saber por que aquele bem patrimonial esta ali, qual o contexto em que ele esta inserido, é o que aponta o Professor E:

"Educação Patrimonial é a gente perceber a existência de algum patrimônio cultural existente na cidade e ao mesmo tempo que a gente tomar conhecimento desse prédio, a gente preservá-lo, conhecendo sua história e sabendo quais motivos ele encontra-se naquele determinado local, o porquê dele estar ali, e qual é a sua...É, o seu contexto histórico, a sua importância, e manter, porque não é o simples fato dele existir e a gente não percebê-lo, a gente perceber, a gente tem que manter, como a gente percebe que hoje em dia alguns já não estão nos seus devidos lugares". (Professor E) 
Através das vozes dos professores pode-se afirmar que elas estão em consonância com os estudiosos do assunto identificados no segundo capítulo desta dissertação e o órgão oficial federal que trata da política de preservação e conservação do Patrimônio no Brasil, IPHAN.

E como postula Florêncio (2012, p. 24) "a Educação Patrimonial deve ser tratada como um conceito basilar para a valorização da diversidade cultural, para o fortalecimento de identidades e de alteridades no mundo contemporâneo".

A Educação Patrimonial para os professores está intrinsecamente ligada à preservação e conservação dos bens patrimoniais, com a educação do aluno para uma consciência e sensibilização de que os bens patrimoniais são de todos, de que a escola é importante para todos.

\footnotetext{
"Acredito que é conservar e manter o patrimônio, o patrimônio histórico, o patrimônio público, que na verdade são patrimônios nossos né". (Professor A)

"Vou dizer aqui, nossa cultura como um todo né". (Professor C)
}

Através da valorização da cultura local, da história, memória e identidade. Não só o Patrimônio material como também o intangível ou imaterial como afirma o professor $\mathrm{C}$ ao se referir à dança, teatro, música e manifestações culturais que ficaram esquecidas com o tempo como os cordões de pássaros e bois bumbá.

"Nós tínhamos aqui em Santarém os bois, por exemplo, os pássaros ai, hoje os meninos nem conhecem esses pássaros que eram na festa junina, porque? Porque não houve uma preocupação em dar continuidade da preservação disso daí". (Professor C)

Pode-se dizer também que é através do conhecimento que poderá haver mudança e transformação na postura dos alunos acerca das questões patrimoniais conforme ressaltam os professores.

Dessa forma, a Educação Patrimonial é uma ferramenta muito importante para a formação cidadã dos alunos da Escola Frei Ambrósio, para uma consciência crítica acerca de sua existência no mundo, ou seja, na escola e nos ambientes por eles vivenciados.

"Bom, a Educação Patrimonial, ela passa por valores, desde a questão do conceito do que é cultura e valorização da questão da cidadania, preservação não só do prédio, mas dos valores específicos que cada cidadão tem". (Professor D) 
Outra importante informação para este estudo foi saber se o Patrimônio Histórico de Santarém, a cultura local e a cidadania são temas abordados nas disciplinas ministradas pelos professores.

"Com certeza, eu tenho uma preocupação muito grande em trabalhar essa questão através das metodologias que eu utilizo na sala de aula como por exemplo a gincana de história que eu faço com os alunos...É, gincana de estudos amazônicos, trabalho uma viagem pela história, são trabalhos de teatro, apresentação teatral e atividades de pesquisa mesmo, de exposições, nós sempre procuramos valorizar a cultura local, através dos trabalhos, mostrar para o aluno que ele precisa conhecer essa história pra poder ele cuidar, cuidar do que é nosso, cuidar do nosso patrimônio". (Professor A)

Ao observar as dependências da Escola Frei Ambrósio é fácil de encontrar traços da Cultura Amazônica através das pinturas nas paredes e muros da Escola, frutos de trabalhos desenvolvidos pelos professores junto aos seus alunos. Durante as idas a Escola para realizar as entrevistas, o pesquisador pode presenciar aulas cujos temas envolviam a história local e regional, apresentações teatrais enfocando a Cidadania o que reforçam a fala do Professor $\mathrm{A}$.

Figura 68 - Detalhe da pintura na parede da Escola que tem por objetivo informar sobre a importância da história da Escola

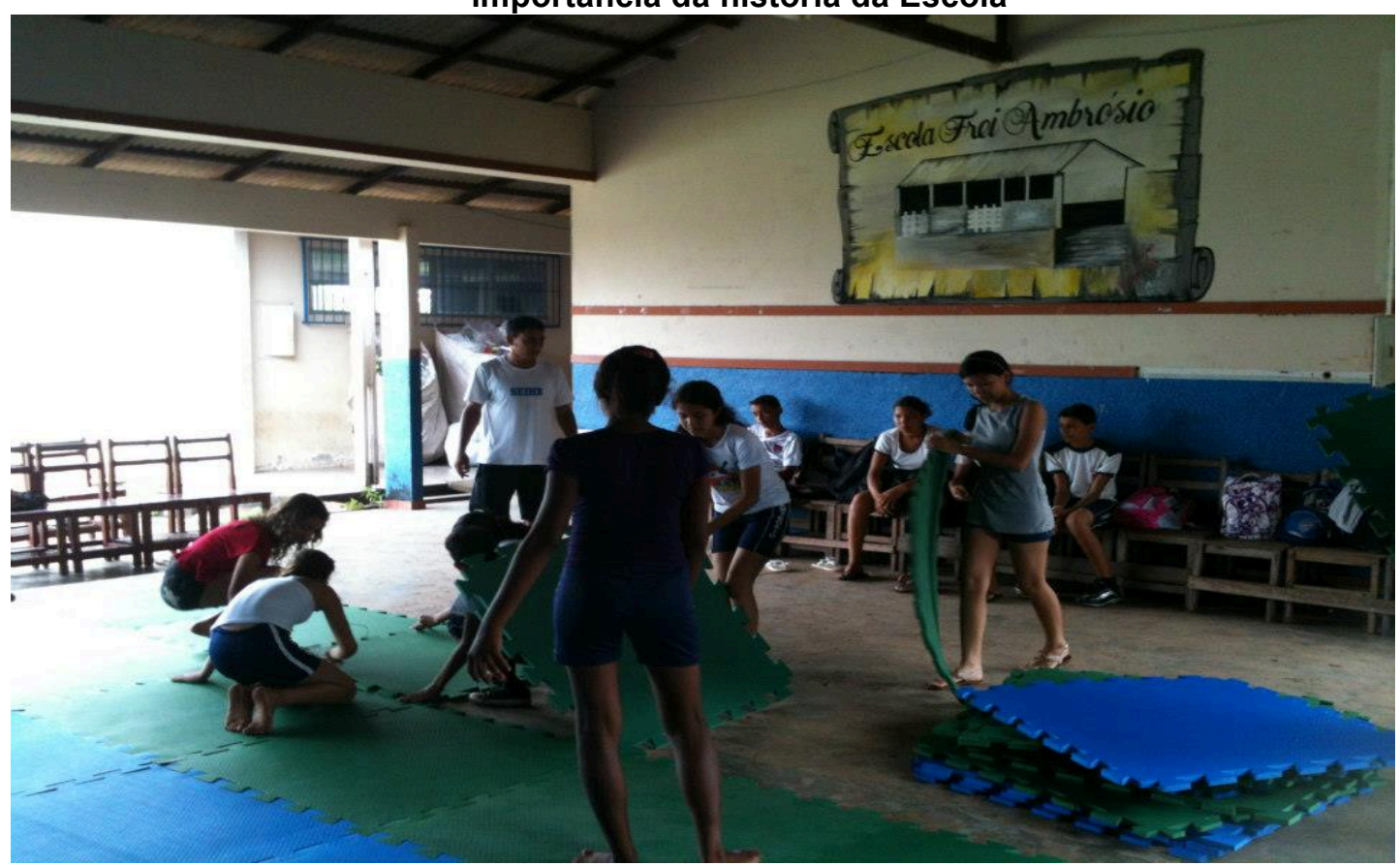

Fonte: Página do Projeto Mais Educação na Internet 
Figura 69- Detalhe da pintura na parede da Escola que tem por objetivo informar sobre a importância da história da Escola I

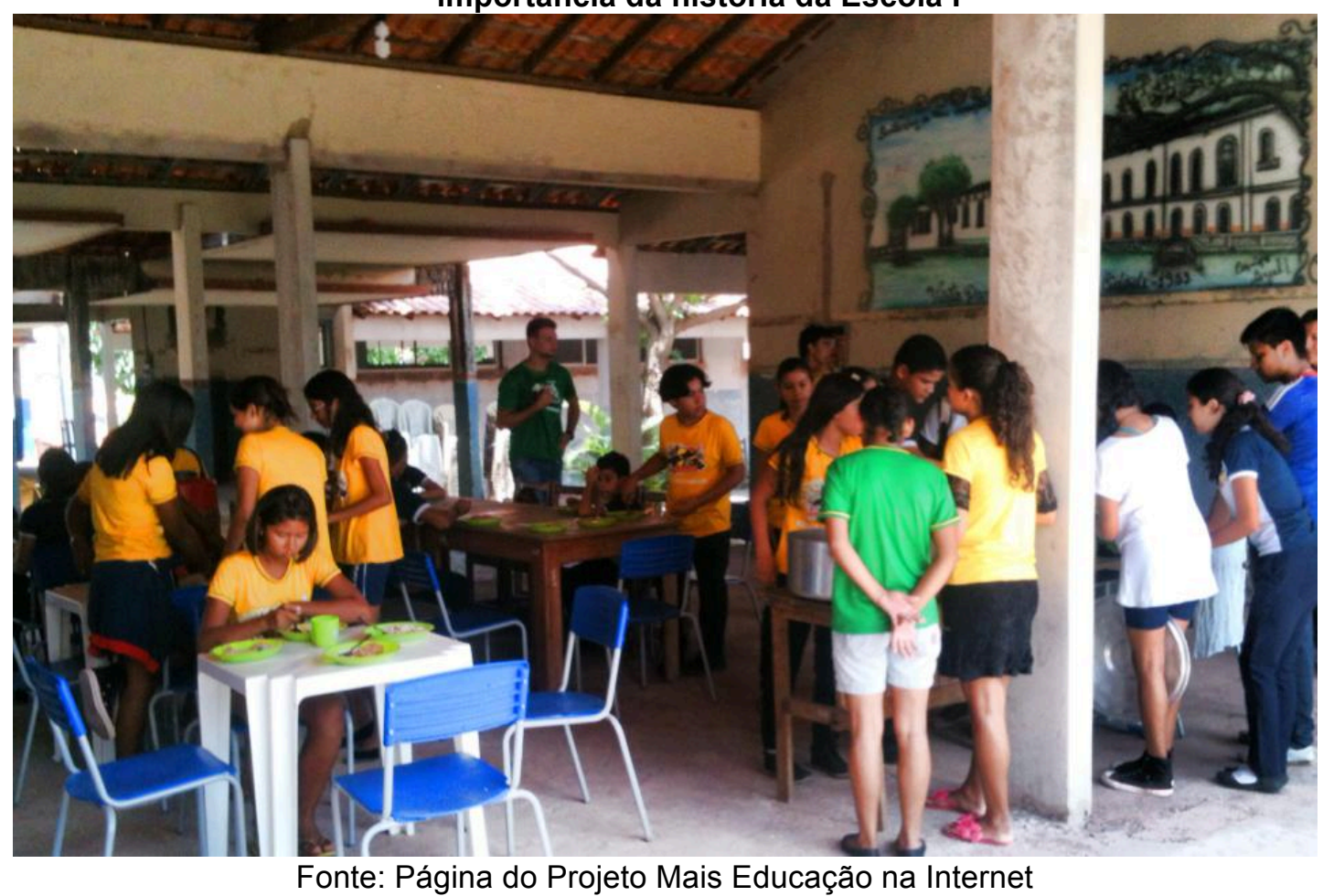

A ida aos museus da cidade são uma constante na Escola Frei Ambrósio, os professores levam seus alunos para descobrirem um pouco mais da história de Santarém e seus antepassados, através das conversas com os atores que por lá se encontram eles obtém novos conhecimentos acerca da Cultura, Identidade e Memória. Praticando a Educação Patrimonial eles são apresentados a um universo que para muitos é novo, instigados pela curiosidade, muitos deles, realizam entrevistas com os atores que lá se encontram.

"São sim, a gente trabalha sim sobre essa questão do patrimônio de Santarém, trabalhamos sim a cultura de Santarém, em estudos amazônicos nós trabalhamos isso, o sexto ano, ele aborda todas essas questões, nós trabalhamos o patrimônio público de Santarém, o museu, a antiga prefeitura, outros tipos de patrimônio que temos aqui em Santarém, é o caso do templo religioso, a própria escola que é aqui o Frei Ambrósio é um patrimônio né, um patrimônio histórico, tem bastante anos e a gente faz toda essa abordagem com eles". (Professor B) 
Figura 70 - Alunos do Projeto Mais Educação em visita a Feira da Cultura Popular

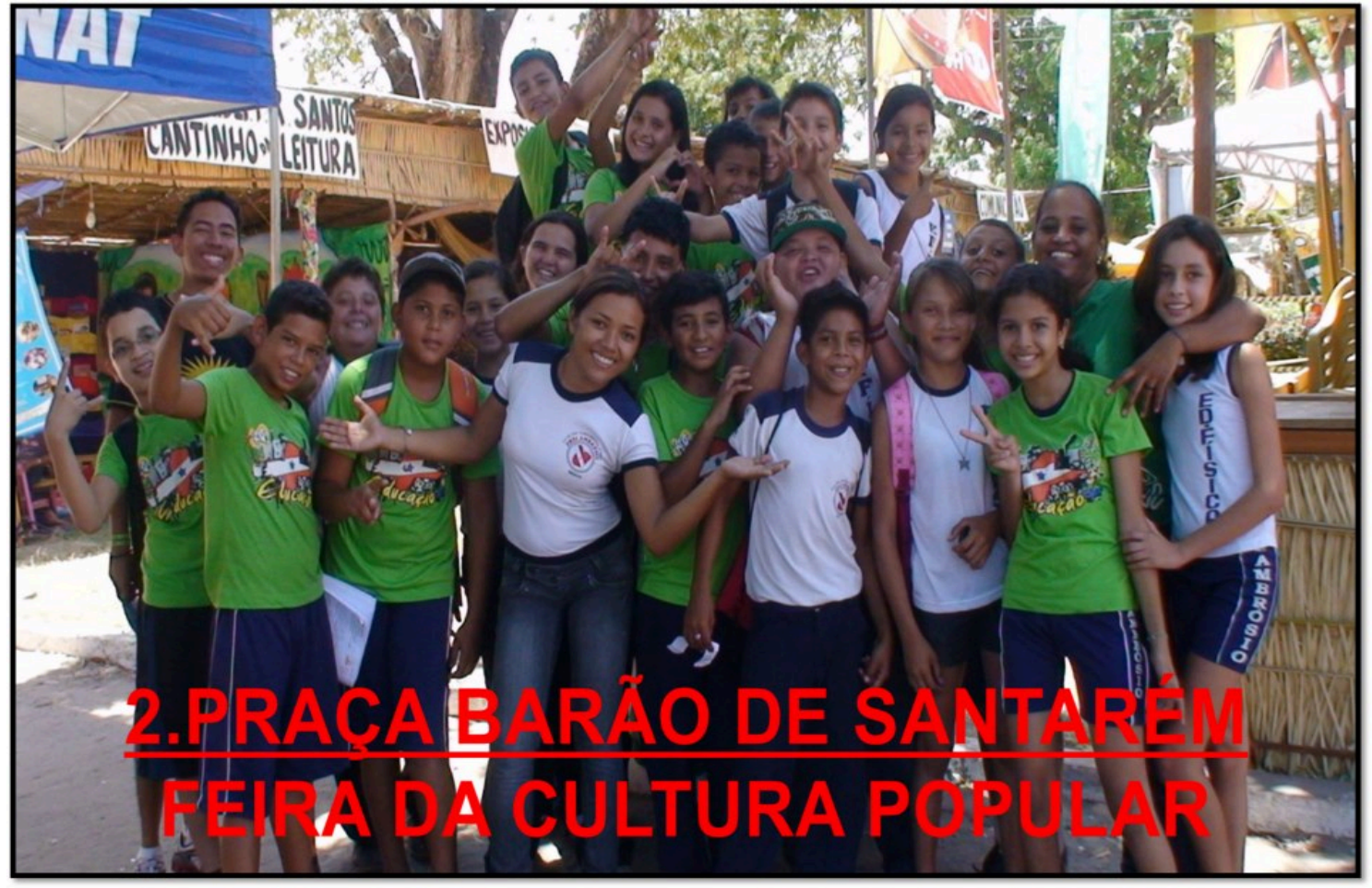

Fonte: Página do Projeto Mais Educação na Internet

Figura 71 - Alunos do Projeto Mais Educação em visita ao Centro Cultural João Fona Ação de Educação Patrimonial desenvolvida pela Escola
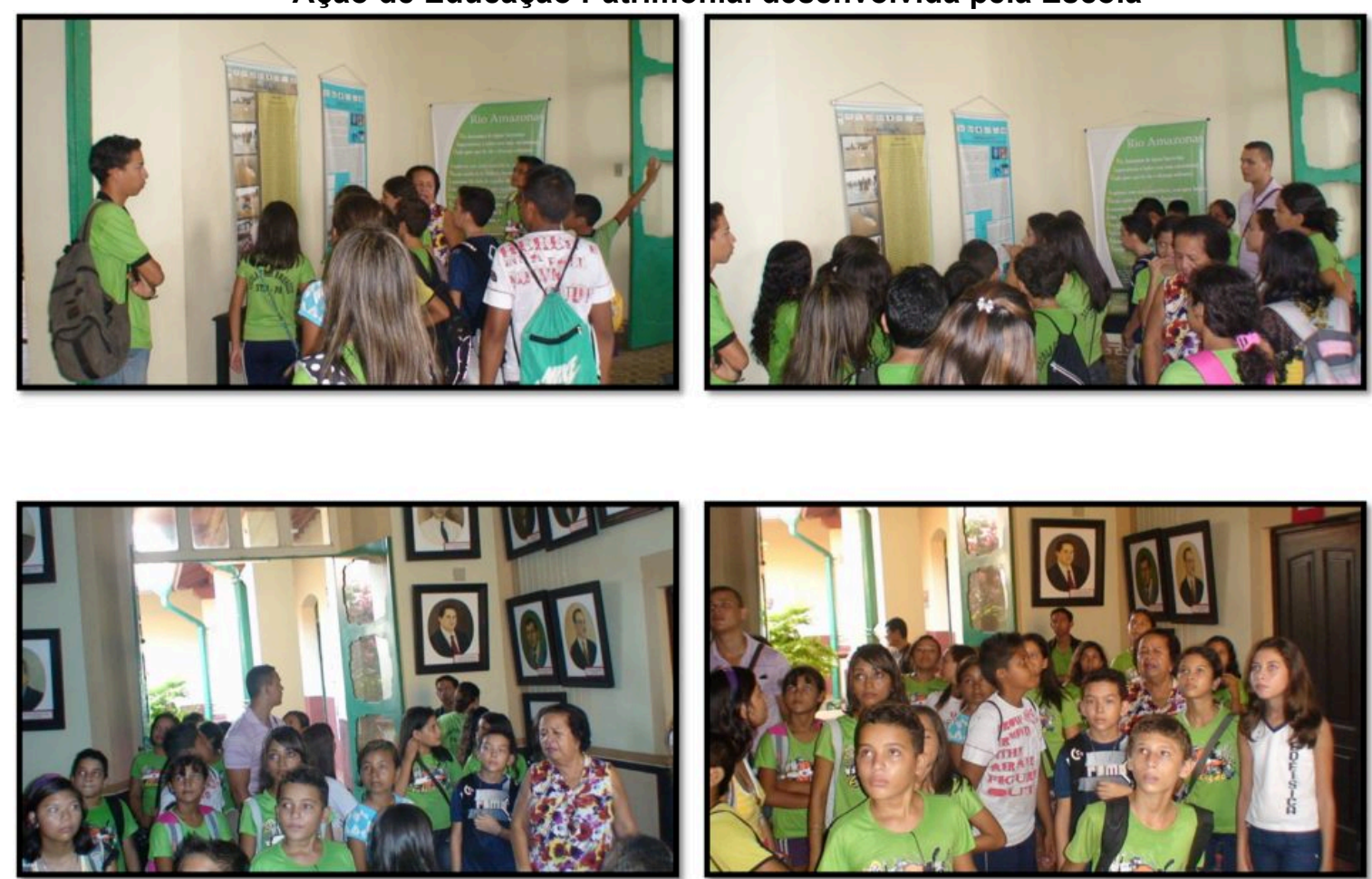

Fonte: Página do Projeto na Internet 
A Educação Patrimonial para o Professor C é tratada como tema transversal, pois através dos eixos temáticos contidos no Projeto Político Pedagógico da Escola ela pode ser inserida em suas aulas, assim como a Cidadania.

"Olha, eu trabalho com a disciplina matemática, mas eu acredito que todos os temas devem ser abordados em todas as disciplinas né, se tu me perguntasse se está dentro do meu conteúdo disciplinar, é claro que ele não vai esta, dentro de conteúdo, mas ele está sim dentro dos eixos, então eu trabalho por exemplo com matemática financeira, dentro da matemática financeira eu trabalho com impostos, então obviamente que eu vou ter que trabalhar né, tô trabalhando de uma certa forma com a questão patrimonial da cidade. A cidadania nem se fala, eu desenvolvo/trabalho com projetos na escola, na verdade eu já trabalho na escola pública com projetos há 14 anos, sempre voltados pra cidadania, porque eu não me vejo enquanto professor de matemática responsável simplesmente por aplicar fórmulas, eu me vejo responsável pela formação cidadã desse aluno né, que a minha matemática sirva pra que ele enquanto cidadão né, que ele, enquanto pai, mãe, enquanto filho, enquanto...Seja o que for né, ela esteja realmente contribuindo". (Professor C)

A fala do Professor C lembra a de Freire quando diz:

Meu papel de professor progressista não é apenas o de ensinar matemática [...] mas o de, tratando a matemática que é, objeto de um lado de meu ensino, de outro, da aprendizagem do aluno, ajudá-lo a reconhecer-se como arquiteto de sua prática cognoscitiva. (FREIRE, 2011, p. 121).

Entre os Projetos e ações que envolvem Educação Patrimonial e Cidadania merecem destaque o Projeto Sol Cidadão Legal com várias atividades desenvolvidas na Escola e fora dela e o Projeto Mais Educação que abarca também uma série de atividades. 
Figura 72 - Alunos do Projeto Mais Educação em Visita ao Centro Cultural João Fona - Ação de Educação Patrimonial/Conversando com o Diretor do Centro, Laurimar Leal
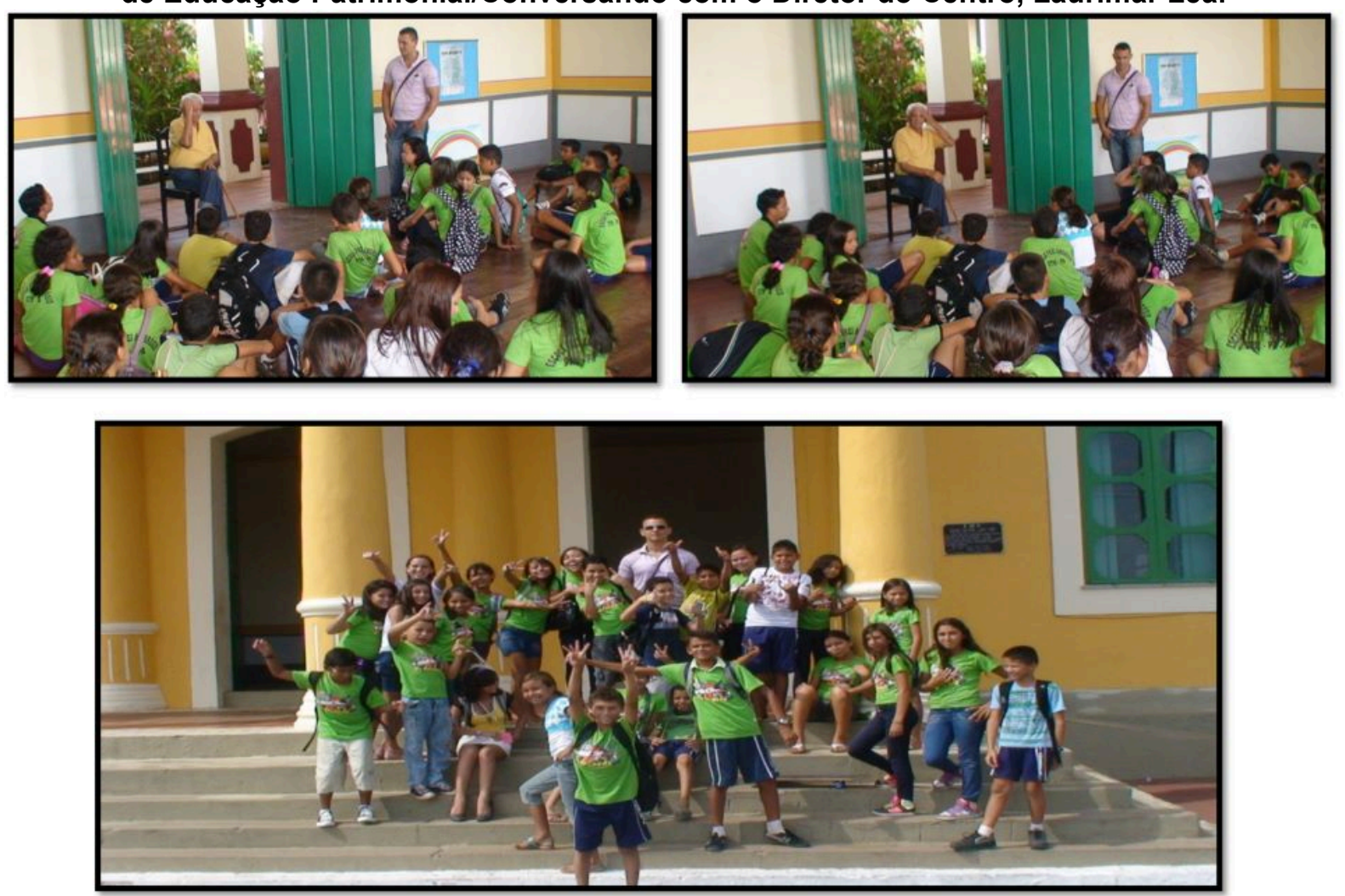

Fonte: Página do Projeto na Internet

Figura 73 - Alunos do Projeto Sol Cidadão Legal depois da apresentação da Peça $O$ Auto da Barca do Fisco que aborda a Cidadania

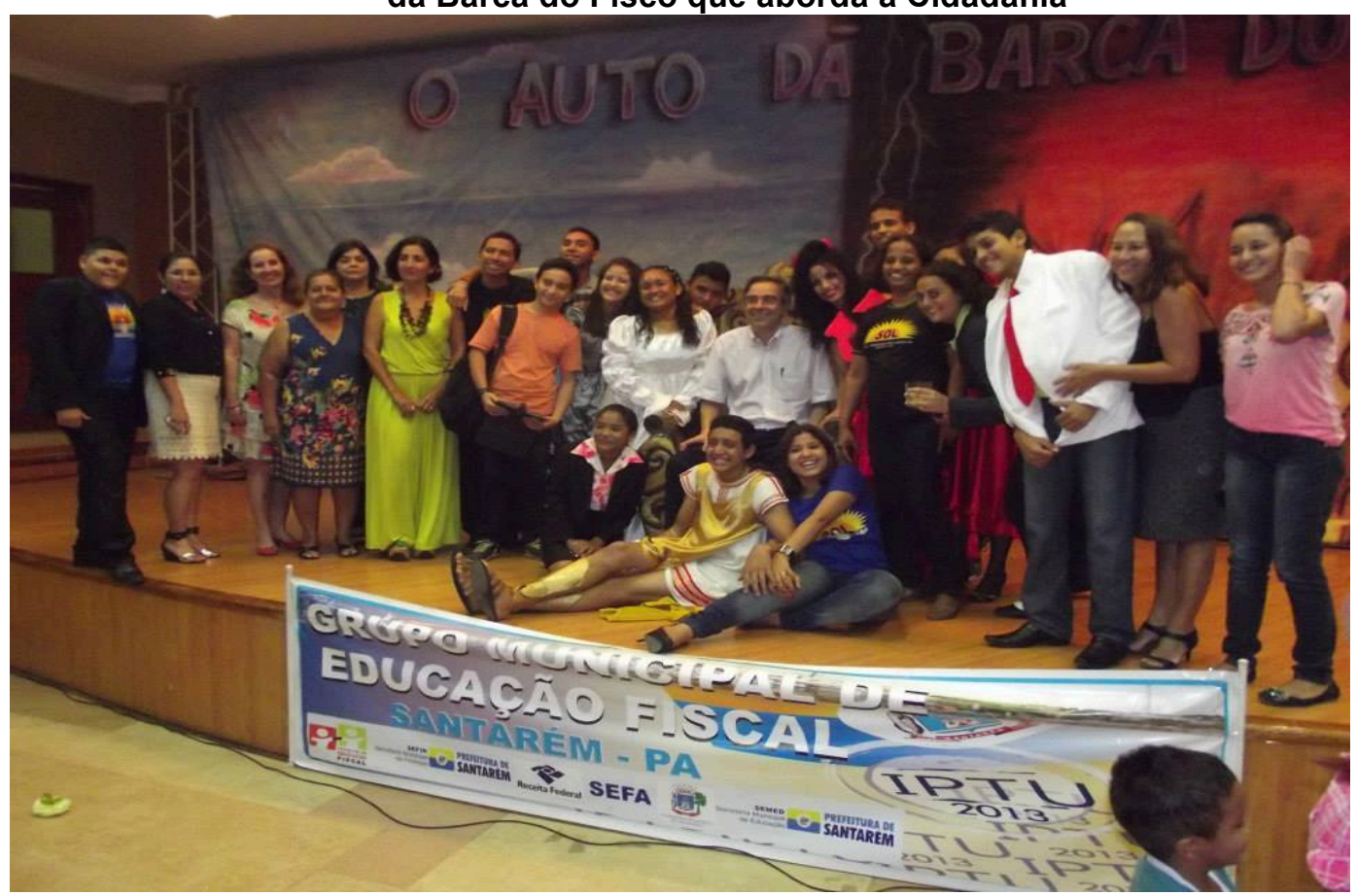

Fonte: Página do Projeto na Internet 
A Escola Frei Ambrósio, através do seu corpo docente, inova em ações e projetos educacionais de forma a proporcionar a seus alunos novas propostas pedagógicas que os conduza a uma teoria alinhada à prática, a exemplo vê-se a proposta elencada pelo Professor D.

"Sim, inclusive é, a gente tem um projeto que é a formação de guias mirins tá, que a gente vai estar estendendo a partir de dezembro de 2014, vem desde a formação dos alunos, que eles tenham a consciência da importância deste lugar, da história do lugar para a sociedade, porque nós entendemos que o aluno, ele, tendo o conhecimento da história, do lugar, que aqui foi uma fortaleza né, do processo histórico da trilogia que a escola passou, ele vai ter mais condições de valorizar, não só a estrutura, mas também os valores e significados da escola, da questão do patrimônio para a sociedade". (Professor D)

A proposta do Projeto Guias Mirins poderá trazer aos alunos muitas experiências acerca do fenômeno turístico e aprofundar conhecimentos importantes referentes à atividade como hospitalidade, história, cultura, patrimônio, identidade, memória e cidadania.

Os Professores entrevistados demonstram através de suas vozes que trabalham os temas Patrimônio, Educação Patrimonial, História local e regional e Cidadania em suas disciplinas como tema transversal e desenvolvem projetos e ações, como explica o Professor E:

\footnotetext{
"Em algumas séries sim, mais assim especificamente no primeiro ano do ensino médio, é, no ensino fundamental, só em algumas séries dependendo do que consta no conteúdo ou assunto em que eu possa encaixá-lo esse, esse tópico do patrimônio né, por exemplo, na sétima série que a gente estuda luz e sombra ai a gente faz um paralelo com o barroco, ai dentro do barroco a gente verifica quais são os prédios que constam, se existe na cidade e ai a gente tenta demonstrar um pouco, mais ai a gente cita sempre fazendo um paralelo com o que a gente tem na cidade e dentro do patrimônio histórico". (Professor E)
}

As respostas só vieram referendar o que antes já havia sido especulado ao se entrevistar os alunos, através da observação participante do pesquisador, das conversas com o diretor e vice-diretora e com uma das pedagogas da Escola.

Os professores desenvolvem projetos, ações, feiras culturais, aulas expositivas, gincanas, teatro, música, dança, acerca de temas que envolvem cidadania, história, cultura local, regional e nacional, Patrimônio, identidade e memória.

Essas atividades proporcionam ao aluno vasto conhecimento acerca de sua formação cidadã e de sua importância enquanto sujeito histórico. Eles têm a 
possibilidade de estabelecerem relações de troca de experiências e aprendizagem com alunos de outras escolas e com os sujeitos que se encontram nos museus, igrejas, festas religiosas, prefeitura e câmara municipal de Santarém.

Além de estarem muito bem informados sobre a história e importância da Escola onde estudam.

A Educação que instiga o aluno a pensar, questionar, refletir, se sensibilizar, conscientizar, que aguça sua curiosidade para as questões em sua volta precisa estar em sintonia com a Educação Patrimonial a fim de se chegar à cidadania.

Para Horta et al. (1999, p. 8) "A Educação Patrimonial consiste em provocar situações de aprendizado sobre o processo cultural e seus produtos e manifestações, que despertem nos alunos o interesse em resolver questões significativas" tanto pessoal como coletivamente. Peregrino (2012, p. 5) endossa o debate ao afirmar que "a Educação Patrimonial apresenta-se como suporte de conhecimento a promover no indivíduo a noção de cidadania, desenvolvendo, assim, de modo coletivo, o sentido de pertencimento e apoderamento". Dessa forma, perguntou-se aos professores se a Educação Patrimonial é um assunto importante para ser tratado com os alunos dentro e fora do ambiente escolar.

"Com certeza, muito importante principalmente porque essa escola, no caso,
o Frei Ambrósio, é a mais antiga de Santarém, então o aluno, ele, precisa
conhecer a história da escola e precisa também ter um olhar de cuidar desse
patrimônio, a muitas vezes ainda, existem alunos que não tem a concepção,
tanto é que você percebe algumas vezes que não cuidam bem do patrimônio,
não zelam tanto como eram pra zelar, então é uma questão de construção
mesmo ao longo do tempo, construção desse conhecimento, então a partir do
momento que for trabalhado, acredito que nós ainda precisamos fazer um
trabalho mais consistente nesse sentido, porque às vezes existem ações,
mas elas são ações muito, elas são ações muito...Assim que não são tão
integradas, acaba não tendo um resultado tão bom quanto deveria ter,
acredito sim que precisa se fazer um trabalho mais consistente". (Professor
A)

O conhecimento e reconhecimento da história da Escola Frei Ambrósio tanto pelos professores como pelos alunos demonstra o quanto ações de Educação Patrimonial são importantes no cotidiano escolar, pois através da informação os alunos vão se familiarizando com aquilo que é seu, embora às vezes isso não esteja claro para ele.

Para Cerqueira (2008, p. 14) a Educação Patrimonial dever ser "necessariamente multidisciplinar e indispensavelmente participativa, precisa não somente introduzir entre os educandos informações técnicas, mas, sobretudo, 
semear a sensibilidade para o Patrimônio Cultural". Nessa perspectiva o Professor B chama a atenção também para a importância do conhecimento acerca da história da Escola, as fases pela qual passou até sua instalação definitiva na atualidade.

\begin{abstract}
"Muito importante, muito importante como já falei é a própria questão do próprio prédio aqui onde está inserida a escola e até o nome da escola, porque esse prédio aqui está a mais de 40 anos aqui já sendo usado, mas a escola tem 114 anos de existência e isso é muito importante para saber de toda uma história de como foi aquele patrimônio, quando foi construído, tempo, qual a importância pra, pra cidade, até pra ele, pra sociedade em geral isso é muito importante o aluno saber". (Professor B)
\end{abstract}

Mais uma vez aparece a Escola como importante Patrimônio Edificado...

"Com certeza, vamos partir do princípio de que nós temos 114 anos de
escola, então nós já somos uma referência dentro da cidade de Santarém,
por termos sido o Forte, pelo privilégio da localização geográfica dentro da
cidade né, por toda uma história ela já é importante né, outro fato é porque,
Santarém, ela é... Eu costumo dizer ela é um berço cultural, então nós temos
sim obrigação de estar dentro da escola trabalhando isso, então, eu acho de
suma importância, porque não basta reclamar que os meninos só ouçam
Rapper é...Funk, né, é aquela questão do preconceito que às vezes temos
enquanto adultos, enquanto mais velhos, não basta, basta oferecer, na
verdade se eles gostam de Rapper, de Funk é porque a mídia, ela faz esse
trabalho todo ai, por outro lado, nós enquanto escola, nós como sociedade
não fazemos, a questão da valorização né, da adaptação de certas culturas
que nós temos durante os anos". (Professor $C$ )

A história da Escola, seus anos de existência contribuindo para a formação de muitas gerações, sua localização geográfica privilegiada são alguns pontos levantados como importantes pelo Professor C que fazem da Escola Frei Ambrósio uma referência na educação local e um importante bem patrimonial que precisa ser preservado e conservado.

Sobre a fala do Professor acerca do Rapper e Funk difundidos amplamente em todo o país como uma "invasão americana" lembrou-se de uma letra de uma extinta banda paraense por nome "Mosaico de Ravena" que tocava muito nos anos 90 a música "Belém, Pará, Brasil" em que certo trecho diz "Aqui a gente toma guaraná, quando não tem coca-cola, chega das coisas da terra, que o que é bom vem lá de fora, transformados até a alma, sem cultura e opinião".

Os dois depoimentos que se seguem dão ênfase também a particularidade da Escola Frei Ambrósio ser centenária e pela cidade de Santarém ter uma Cultura rica e diversificada. Para a Constituição Federal de 1988 em seu artigo 216 Cultura engendra todas as ações por meio dos quais os povos expressam suas "formas de criar e viver". Nessa perspectiva o IPHAN (2012, p. 7) postula que a Cultura 
"engloba tanto a linguagem com que as pessoas se comunicam, contam suas histórias, fazem seus poemas, quanto a forma como constroem suas casas, preparam seus alimentos, rezam, fazem suas festas".

\begin{abstract}
"Com certeza, não só porque é uma escola centenária, mas é uma escola em que nós, por ser a escola mais antiga, nossa cidade é uma cidade cheia de história, assim como qualquer cidade e que os livros didáticos ou poucas pessoas conhecem essa história, então é importante a gente passar isso na escola, na sala de aula pra que o aluno, ele conheça a história do lugar e tenda a valorizar a importância da educação patrimonial, do que é cultura, do que é cidadania, do que que é os conceitos históricos, a importância da escola Frei Ambrósio pra ele enquanto cidadão e assim ele vai ter mais cuidado, mais preocupação de zelar né, pela escola e também manter viva essa questão cultural". (Professor D)

"Com certeza, de suma importância, tanto que nós estamos em um, a nossa escola é um patrimônio histórico cultural, é o prédio mais antigo da cidade, foi aqui que dentro da nossa história foi a fortaleza né, então, claro que ela não está... O nosso prédio escolar está passando por uma reforma e a gente está percebendo que não está sendo mantido algumas, algumas características né, algumas coisas estão sendo modificadas, mas é muito importante que os alunos conheçam, preservem os patrimônios, tenham esse conhecimento sobre o que é o patrimônio, pra vida, pra cultura, enfim". (Professor E)
\end{abstract}

O Professor D chama a atenção para a carência de livros com informação sobre a história da cidade bem como o desconhecimento de boa parte da população. Esse professor entende que o aluno informado vai ter mais cuidado e zelo pela Escola e pelos bens patrimoniais. Já o Professor $E$ reforça a importância do conhecimento sobre os bens patrimoniais para a perpetuação da Cultura local.

A Educação Patrimonial é um tema contemporâneo de suma importância no mundo, no país e não seria diferente em Santarém, logo, os professores foram unânimes em concordar que ela é muito importante para os alunos da Escola Frei Ambrósio.

Através do ensino da Educação Patrimonial os alunos tem o conhecimento sobre a Escola Frei Ambrósio, sobre sua importância enquanto patrimônio histórico e para a educação na cidade. Tem conhecimento sobre cultura, patrimônio histórico e cidadania. Esses alunos bem informados podem vir a serem disseminadores de comportamentos e posturas a favor da conservação e preservação dos bens patrimoniais.

Nessa perspectiva Pelegrini (2009), infere que a inclusão da Educação Patrimonial no ensino fundamental poderá contemplar as identidades plurais e suas 
respectivas memórias, para essa autora a "inclusão da Educação Patrimonial nos diversos níveis de ensino possibilita a irradiação dessas concepções". (PELEGRINI, 2009, p. 114)

Para Soares citado por Oliveira e Wenceslau (2007, p. 33) "a Educação Patrimonial, quando aplicada desde as séries iniciais, vai ao encontro dos educandos que, ainda não tendo uma carga de valores totalmente formada, possuem um maior potencial para adquirir e transmitir" noções de preservação dos bens patrimoniais nos seus espaços de vivência.

Assim, a Educação Patrimonial pode ser uma importante aliada dos professores para uma consciência cidadã em relação aos seus alunos.

Considerando que a Escola Frei Ambrósio desenvolve ações e projetos que envolvem temas como história da Escola, Educação Patrimonial, Cultura e Cidadania referendadas, inclusive, em seu Projeto Político Pedagógico, indagou-se junto aos professores se eles tinham esse conhecimento ou mesmo se estavam inseridos nessas atividades:

\footnotetext{
"Sim, a escola, ela, trabalha com vários projetos né, tem o Projeto Sol, tem o Projeto da Prefeitura Mirim, e tem os subprojetos que são desenvolvidos pelos professores, que no meu caso trabalho dentro da minha área de história, são projetos mais voltados pra produção dentro da sala de aula, então, nessas atividades que nós desenvolvemos, nós sempre estamos buscando essa educação, essa sensibilização da importância de cuidarmos do patrimônio, do patrimônio público, do patrimônio histórico, daquilo que pertence a nós". (Professor A)
}

O Projeto Sol Cidadão Legal da qual faz parte a Prefeitura Mirim da Escola Frei Ambrósio foi lembrado pelo Professor A, sendo que também são desenvolvidos outros subprojetos em sala de aula visando a Educação e a sensibilização para o Patrimônio público e histórico da cidade, afinal o Patrimônio público é de todos.

Do mesmo pensamento comunga o Professor B ao destacar o Projeto Sol Cidadão Legal como referência quando se trata de educação fiscal e Cidadania. 
histórico, patrimônio cultural, patrimônio da escola, o patrimônio que tem aqui em Santarém e na própria escola”. (Professor B)

Figura 74 - Alunos do Projeto Sol Cidadão Legal em atividade contra o Racismo/Afirmação Identidade

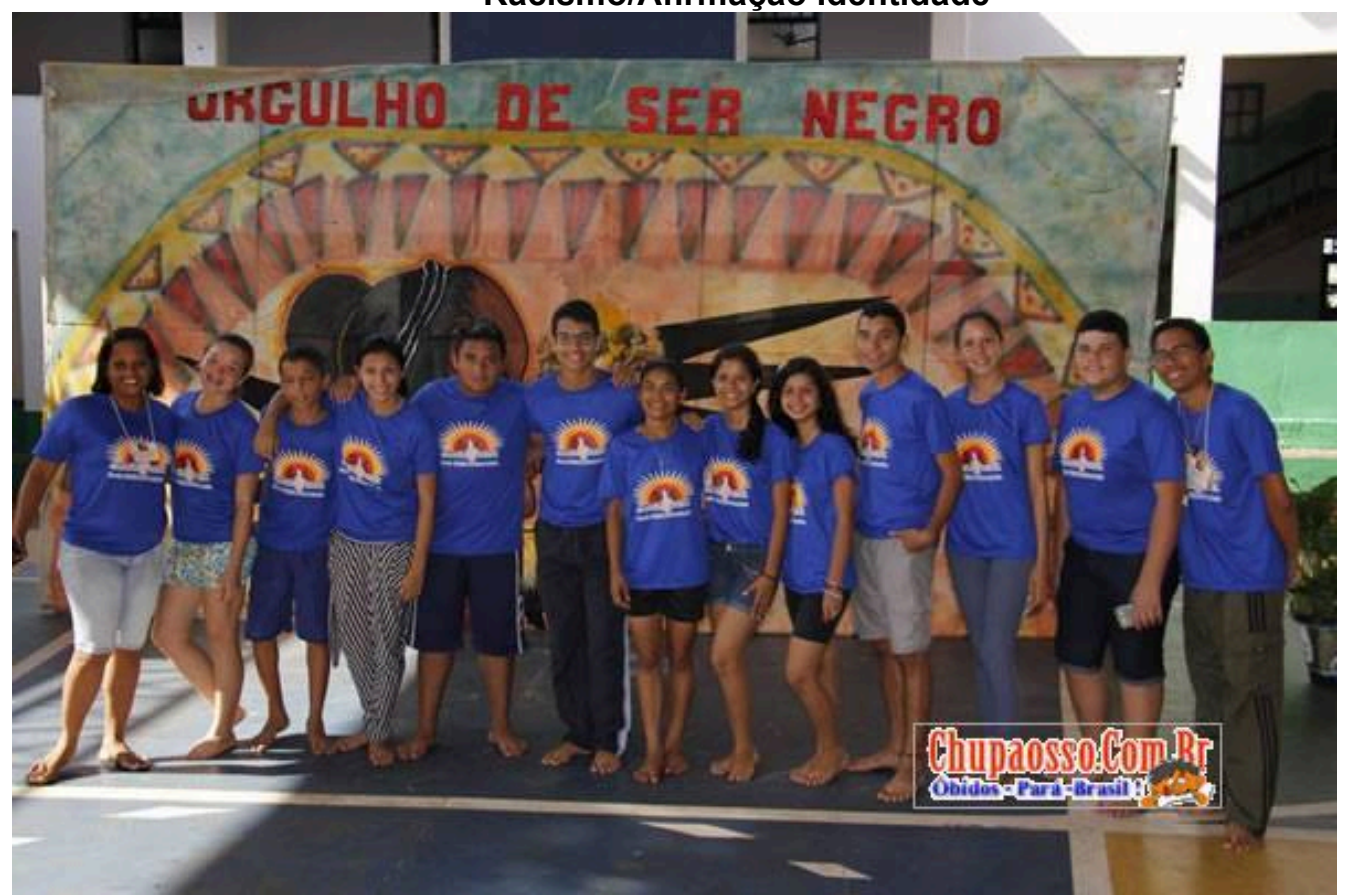

Fonte: Página do Projeto na Internet

Figura 75 - Alunos do Projeto Sol Cidadão Legal realizando atividade que envolve Cidadania

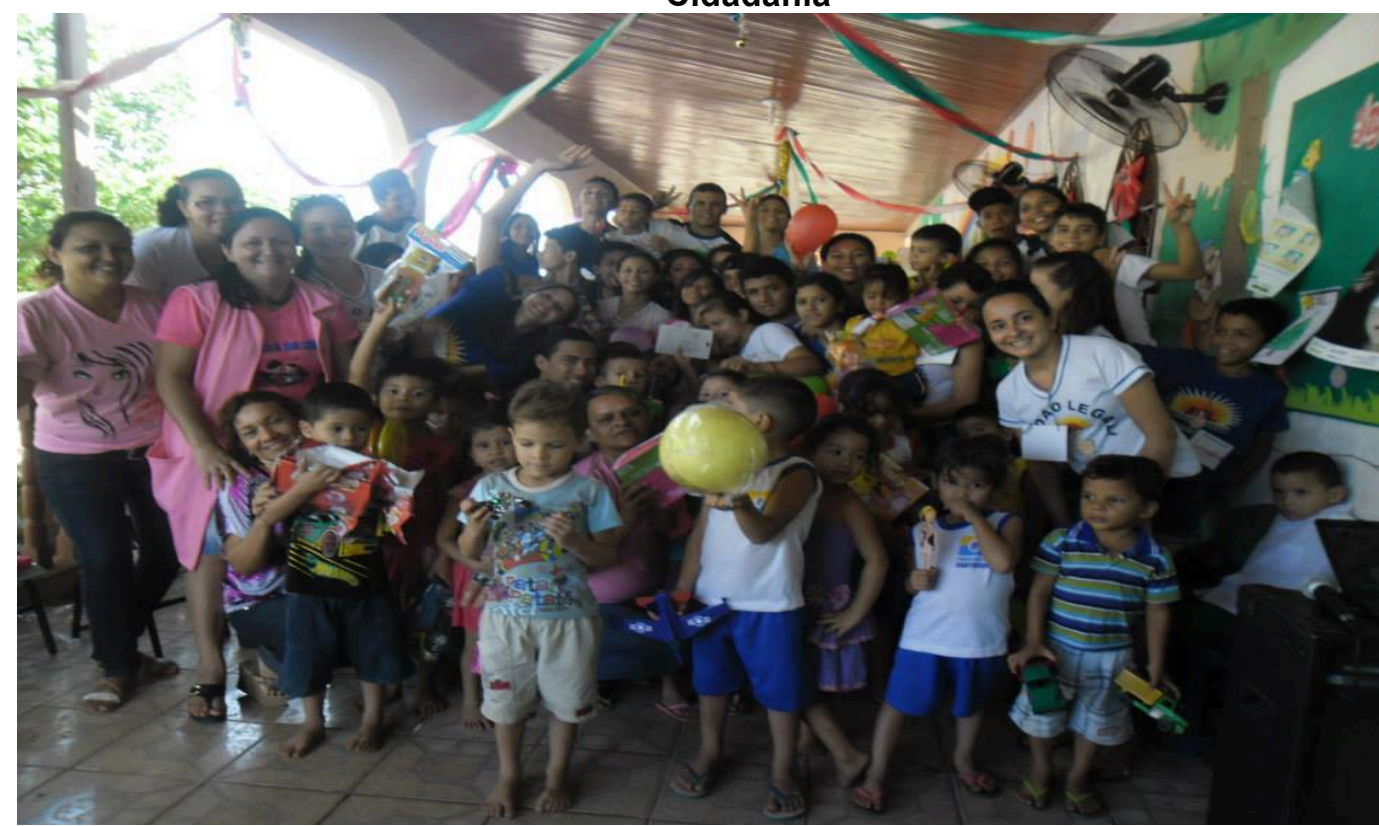

Fonte: Página do Projeto na Internet 
O Professor D também enfatizou o Projeto Sol Cidadão Legal. Para esse professor melhorias como a reforma da quadra esportiva e construção do auditório da Escola foram ganhos advindos desse Projeto.

\begin{abstract}
"Olha nós temos aqui na escola o Projeto Sol Cidadão Legal, dentro do Projeto Sol Cidadão Legal que é uma parceria com a Receita Federal nós trabalhamos a questão do que é ser cidadão, o guia mirim, nós temos o prefeito, nós temos os vereadores dentro da escola, então eles, por exemplo, a nossa quadra hoje, a nossa escola, só está sendo reformada, foi diante de uma...Da eleição do prefeito, dos vereadores, que fizeram um documento e entregaram para...É, na época o vice governador, o Helenilson (Helenilson Pontes era o vice governador do Estado do Pará, à época), que ainda continua na realidade, e ele deu uma olhada especial pra nossa escola, então a prefeitura mirim trabalha com essa questão de cidadania, de preservação, inclusive, eles tiveram palestras, alguns vereadores vieram aqui $e$ conversaram com eles falaram da questão dos direitos e deveres, a questão patrimonial, então, o nosso Projeto Cidadão Legal dentro da escola, ele trabalha essa temática". (Professor D)
\end{abstract}

"Olha, eu não tenho conhecimento, se já houve algum projeto nesse sentido, mas assim, dentre alguns anos atrás teve um projeto na feira que eu fiz sobre...É, o patrimônio né, foi um projeto pequeno, não foi um projeto de grande extensão, somente para uma apresentação em sala de aula e que se estendeu até a nossa feira do conhecimento, mas assim um grande projeto na escola eu não tenho conhecimento se há". (Professor E)

Com exceção do professor $\mathrm{E}$, os demais professores tem conhecimento ou estão inseridos em algum projeto que trata dos assuntos como Cidadania e Educação Patrimonial na Escola Frei Ambrósio.

Através das entrevistas pode-se perceber que existem Projetos como o Sol Cidadão Legal que aborda diretamente a questão da Cidadania, o Projeto Mais Educação que trabalha com o Patrimônio Histórico, O PROEMI também trata de assuntos como Cultura e Patrimônio, inclusive, o professor D informou que desenvolveu no passado uma ação que visou mostrar a importância da Escola Frei Ambrósio como Patrimônio Histórico e para a educação em Santarém, "De uma Fortaleza a uma forte Escola".

Outro projeto que está em estudo é a "Formação de Guias Mirins", que tem por objetivo preparar os alunos para receberem os turistas e visitantes que adentram a Escola com informações sobre a história da Escola e sua localização privilegiada no contexto do turismo local.

Dessa forma, a Escola tem a intenção de preparar seus alunos para a prática do Turismo Cidadão visando receber os turistas que por ventura adentrem o espaço Escolar. Através desse Projeto os alunos poderão ter noções básicas sobre Turismo 
e toda a sua cadeia produtiva, sua importância enquanto fenômeno social e atividade que faz parte da vida do homem moderno.

Sabe-se que os Patrimônios Edificados dizem muito sobre a cidade e seus moradores, estes também, se constituem como lugar de memória que conforme Gastal (2002, p. 77) é "aquele local, bairro, rua, prédio ou mesmo objeto em que a comunidade vê partes significativas do seu passado com imensurável valor afetivo". Diante do postulado pela autora, se questionou aos professores suas opiniões acerca dos Patrimônios Edificados no Centro Histórico de Santarém, se esses Patrimônios estimulam o Turismo na cidade.

\begin{abstract}
"Acredito que eles estimulam, mas é preciso se fazer um trabalho melhor nesse sentido, por que...Porque uma boa parte desses patrimônios, eles são desconhecidos até mesmo pela população. A população não conhece a sua história, na verdade, nós fazemos um trabalhinho de formiguinha né, mas seria necessário um trabalho até mesmo da secretaria de turismo, secretaria de cultura, voltado para a valorização desse patrimônio. Santarém é muito rica na sua cultura, ela tem um patrimônio cultural histórico muito rico, mas ele ainda não é explorado da forma que deveria ser. Talvez falte mais políticas voltadas pra esse sentido". (Professor A)
\end{abstract}

Os Patrimônios Edificados no Centro Histórico de Santarém, conforme o Professor A, estimulam o Turismo, porém ainda faltam ações mais eficazes tanto por parte das escolas e principalmente pelo poder público. O Professor sugere a maior participação do poder público através das Secretarias Municipais de Cultura e Turismo nesse processo, através de ações concretas de sensibilização e esclarecimento acerca da importância dos bens patrimoniais para a história, cultura e turismo.

\footnotetext{
"Na minha opinião tem alguns... É, desses patrimônios, que eles estão apenas para a história mesmo, uns que estão apenas para a história, apesar da importância que eles tem, não tá tendo um esclarecimento, uma informação maior desses patrimônios, muitas vezes o próprio alunado, a própria sociedade, às pessoas aqui da cidade, eles não tem o conhecimento realmente desses patrimônios, e às vezes a gente só vê falar desses patrimônios dentro da escola né, dentro da escola quando a gente tá trabalhando uma disciplina tal ou uma disciplina específica sobre o patrimônio como é o caso da Taperinha, que tem uma história já de bastante tempo, bem longa, e o caso do... Até o próprio museu de Santarém, às vezes não tem uma informação melhor, mais clara sobre ele, e às vezes é pouco visitado, mas são patrimônios importantes, se fosse...Tivesse uma informação melhor, uma divulgação maior sobre a importância dele, seria mais visitado, seria também centro de turismo também pra cidade" (Professor B).
} 
A fala do professor B está em consonância com o professor A no que se refere à falta de informação e conhecimento de muitos alunos e moradores da cidade sobre seus bens patrimoniais. Essa carência de informação é ruim, pois não se preserva ou conserva aquilo que não se conhece, aquilo que the é desconhecido.

Conforme os professores $A$ e $B$, as questões sobre o Patrimônio local e sua importância para o turismo ainda são muito pontuais, dentro da Escola e no contexto de determinada disciplina. Faltam ações mais concretas que precisam ser trabalhadas de forma integrada na Escola como um todo.

O poder público tem papel fundamental no processo de promoção dos bens patrimoniais através de campanhas de Educação Patrimonial com objetivo de conscientizar e sensibilizar a comunidade acerca da importância de se preservar e conservar os bens patrimoniais. Cabe à comunidade cobrar e fiscalizar do poder público ações de preservação e conservação do patrimônio, que é de todos. Dessa forma, Braga (2011, p. 20) esclarece:

A importância do tema Patrimônio Cultural, como elemento de pertencimento
dos indivíduos à sua coletividade, poderá tornar-se uma importante atitude
para a formação de verdadeiros agentes do desenvolvimento local. Crianças,
adolescentes, líderes comunitários, empresários, entre outros segmentos da
sociedade, por meio de um processo educativo, podem passar a valorizar e
considerar o Patrimônio Cultural como elemento chave para um
desenvolvimento sustentável. Sustentável porque permanece, porque
preserva, porque educa [...] A Educação Patrimonial e a Cidadania são os
fundamentos de qualquer ação, programa ou processo de preservação do
Patrimônio Cultural.

Com uma leitura bem aprofundada e incisiva o Professor $\mathrm{C}$ se posicionou sobre a questão Patrimonial e sua importância para o Turismo na Cidade:

"Eu acredito que sim né eu acho que toda a ação que seja voltada para esse sentido, ela tem uma importância significativa né, mas eu acho que também não pode ficar só nisso [...] Se nós enquanto cidade de Santarém, que somos uma cidade turística, temos um potencial turístico muito grande, nós precisamos aprender a preservar isso. Porque não colocar, por exemplo, guias mirins? [...] Eu entendo a educação patrimonial como esse contexto todo, são coisas simples, sabe, ai dentro das disciplinas, por exemplo, é a questão de espaço, ali entra a geografia, entra a história, entra tudo, mas é claro que tem um incentivo. Quer um outro exemplo: o Sairé, o Sairé, ele está dentro do calendário do município de Santarém, mas não está dentro do calendário escolar. Nós levamos o Mais Educação pro dia da abertura que é aquela parte que tem o ritual... Nós levamos nossos alunos, eles ficaram encantados, eles fizeram entrevistas com os mordomos, eles produziram um vídeo bacana e tu precisavas ver assim sabe a eloquência deles fazendo o trabalho, porque tavam conhecendo coisas novas né, ai a gente diz assim, áh o aluno é não quer...Não quer porque não é oferecido, se partir vamos dizer, do poder público poderia colocar dentro do calendário é, da educação em que 
as escolas pudessem ter mais acesso, porque nem todas estavam lá no Sairé, por exemplo, ai eu vou estender mais não só lá, como a questão de espaço na cidade, a questão do museu, se tivesse realmente um incentivo, que a gente chama isso tudo como educação patrimonial, ai com certeza absoluta os resultados seriam outros. Mas ai a gente fica...Só vamos botar plaquinha... E aí? Até o próprio aluno do Dom Amando tenho certeza absoluta que ele não tem conhecimento daquela plaquinha lá na frente né, ai todo mundo passa, tem uns que nem veem e tudo, eu acho que é muito mais do que plaquear. Eu acho que tombamento é sim importante, mas não vamos só tombar fisicamente, vamo tombar sabe...E dá uma utilização pra isso, que qualquer pessoa, qualquer aluno, dessa nossa cidade, jovem, adulto, sinta que é seu [...]Então, eu acho que se nós somos um polo turístico e nós temos sim tudo pra isso né, porque não abraçar de vez, mas tem que começar por ai, fazer com nossas crianças e isso envolve meninos desde 4, 5 anos, os nossos adolescentes, os nossos jovens, nossos adultos, criem uma relação de pertencimento né, mas eu só vou poder dizer que isso é meu se realmente eu me apoderar disso né, e essa informação, ela tem que chegar, ela não tem que chegar de uma forma elitizada, só por tabela né...Há, vamo tombar ali e todo mundo sabe, vamo lançar um livro ali [...] Então se houvesse esse direcionamento do poder público, que eu acho que deveria ser incitado pela universidade, sabe, a universidade...Vamos lá, vamos estudar de que maneira...Eu acho que o ponto, seria dai de discussão...Como o poder público tá instituindo dentro dos conteúdos programáticos, dentro dos parâmetros, pra que a cidade toda, pra que as escolas todas estivessem sendo obrigadas sim a trabalhar dentro de suas bases é, paralelamente, que se chegassem as associações de bairro, quer dizer, existe todo um trabalho ai que precisa ser feito, e eu te digo, sinceramente, é tão fácil, eu não vejo dificuldade, porque se isso chegar amarrado na minha escola, evidentemente que a escola vai instituir, sabe, e a partir daí se fossem promovidos eventos na cidade, onde das escolas saíssem né, essa questão [...] É claro que ele (o aluno) vai dizer que aquilo é feio (se referindo as esculturas da Praça Barão de Santarém), ele não sabe pra que é, mas a partir do momento que ele conhece a história daquilo que ele sabe quem é né...Outra coisa que eu vou te dizer, vou de novo citar o Laurimar Leal, que eu acho que pra mim é uma peça rara em Santarém, o Laurimar Leal, ele já tá cego, então ele vive lá naquele museu (Centro Cultural João Fona), um dos sonhos do Laurimar Leal é escrever, pra tu teres uma ideia, tudo o que ele sabe, e simplesmente o poder público, ele, não disponibiliza alguém para escrever, tá lá, se você for ver, quando nós passamos por lá, os nossos alunos que chegavam a escrever pra ele, ele fez um caderno a mão e ele vai ditando...Ele quer alguém que termine isso...É a nossa história que tá ali, sabe, e tá lá daqui a pouco o Laurimar se vai, é mais um...Como a Dica Frazão se vai e não ficou nada de registros ai depois vai se fazer é homenagem, uma placa...E ai, o que ficou, quantas histórias se ficaram né?". (Professor C)

O professor $\mathrm{C}$ tece algumas críticas de como as ações concernentes ao Patrimônio Edificado vem sendo desenvolvidas na cidade, como a simples colocação de placas em alguns desses patrimônios, sem ter uma divulgação e informação mais abrangente como campanhas de conscientização e sensibilização. O Patrimônio fica restrito, conforme explica o professor, a uma pequena parcela da população, quando deveria ter um alcance muito maior se houver ações mais 
abrangentes. É nesse ponto que entra o papel da Educação Patrimonial como forma de conscientização da sociedade sobre o conhecimento dos seus bens, sua importância e seu valor enquanto referências identitárias. Um olhar que outrora era mediado pelo senso comum pode, com processos educativos, ser ressignificado. Essa ressignificação pressupõe um exercício de Turismo Cidadão, pois deduz o reconhecimento e processos de identificação dos bens que fazem parte do seu cotidiano, estabelecendo com eles novos laços afetivos.

"Não é só tombar o Colégio Dom Amando, colocar uma plaquinha lá na frente, não é só tombar o Casarão e colocar lá, se a gente for ver, inclusive, essas plaquetas que foram colocadas, elas já estão até danificadas, claro, porque fica restrito a público ali, às pessoas que não tem acesso a essas informações, eles vão passar de madrugada e não vão ter aquele cuidado, acho que tombar...Deveria ser tombado de uma forma muito mais ampla, acho que poderia ter sido feito um trabalho, pode ser feito um trabalho muito maior nas escolas né". (Professor C)

Esse professor critica a ausência da Universidade nas discussões sobre Patrimônio junto ao poder público, para ele a Universidade tem um papel fundamental no processo de construção e disseminação do conhecimento acerca do tema Patrimônio, o que não vem ocorrendo na Cidade.

"Ai eu vou chamar a atenção para as universidades, acho uma falha muito grande das universidades né, vamo de cima pra baixo, cadê as universidades que não vem fazer esse tipo de...Sabe, cadê os projetos voltados pra isso? Eu acho que a universidade, ela teria por obrigação tá dentro das escolas [...] Se tu fores ver, nas universidades não se discute isso [...]". (Professor C)

Conforme o Professor $\mathrm{C}$, faltam ações concretas do poder público em relação à valorização do Patrimônio material e imaterial, pouco valor se dá a artistas como Laurimar Leal, Dica Frazão e muitos outros que já estão em idade avançada e não se tem quase nada de registros sobre essas personalidades vivas, verdadeiros Patrimônios Vivos.

"Tá aqui a Praça São Sebastião né, onde dentro da Praça São Sebastião (Barão de Santarém), nós temos essas esculturas feitas por Laurimar Leal, a grande maioria da população, primeiro, não tem ideia desses vasos cariátides, tem ideia só de que foi feito alguma coisa, não tem ideia de que foi Laurimar Leal né, que contribuiu pro desenho e pra confecção dessas coisas ai, e com isso se destrói tudo...Eu acho que é assim sabe, se a educação patrimonial vem dentro do plano de diretrizes da cidade já que ela é um polo turístico, já que nós temos reconhecidamente no mundo, inclusive, as nossas riquezas patrimoniais, sejam elas materiais ou imateriais, ora, deveria vir dentro pra que então as escolas fossem forçadas ou direcionadas a trabalharem essa questão do patrimônio da cidade, e ai eu não falo só do físico né, eu falo não só do Laurimar Leal, mas da Dica Frazão né, de vários 
outros artistas que nós temos aqui na nossa cidade e que são bens patrimoniais nossos, por exemplo né". (Professor C)

\section{O Professor $D$ confidenciou que tem vários projetos pensados para serem} colocados em prática na Escola Frei Ambrósio, alguns já são realidade, outros ainda estão em fase de estudos e outros ainda são sonhos.

"Eu tenho um sonho: o meu sonho é de ter um memorial da fortaleza, junto a Escola Frei Ambrósio e pelo menos dois canhões sejam remanejados pra cá, porque das pessoas que eu ouvi, em suas memórias, elas colocaram né de estar brincando, estudando e brincando, os canhões fazem parte do imaginário de muitas crianças e como historiador eu tenho... Eu sinto essa necessidade de estar recuperando uma parte da memória desta escola, deste lugar [...] Vejo que muitas coisas do centro foram demolidas, principalmente na década de 70. Essa escadaria que construíram aqui ao lado do mirante, essa escadaria não deveria ser ai, a escadaria deveria ser mais aqui em baixo, que eles chamavam de escadaria Frei Ambrósio, que tinha um corre mão... Muitos meninos na época, hoje já de uma certa idade, escorregavam, então tem muitas memórias desse lugar. O teatro Victória que também foi destruído diante de um processo de uma ação foi recuperado, mas você se sabe que não se recupera tal qual, vejo que, por exemplo, o Solar do Barão não deveria ser um prédio comercial, porque isso tá relacionado a história, o Barão, foi o Barão que mais teve escravos em Santarém né e quase não é...Se você analisar pelas seis portas, você vai ver que pela historiografia era os aposentos dos escravos é... E o Barão foi uma pessoa que recebeu um título de Dom Pedro II pra ser o dirigente do lugar né , então, eu acho que deveria ter dado uma história...Um contexto bem maior para o Solar do Barão, o Solar do Barão de São Nicolau que é ao lado também, que é o único solar que tem um relógio solar que não funciona, mas que pra época foi de importância né, então, a própria Matriz, onde ela...Onde a igreja foi construída, é... É, a primeira igreja onde tem aquele crucifixo, quase em frente ao Teatro Victória né, eu acho assim que a Praça Rodrigues dos Santos poderia ser dado um novo olhar, assim como o Mercado Modelo, porque se você for em Manaus, você vê um exemplo de preservação da história, da borracha, dos palacetes é... O teatro, é algo que eles valorizam a história, aqui em Santarém nós não temos algo que nos identifique, até os próprios prédios não são identificados, não são dado uma importância que merecia ser dada, porque assim, um povo sem história é um povo sem memória né, essas pessoas vão morrer, a própria Dica Frazão, por exemplo, é uma artesã conhecidérrima fora de Santarém, o que ela faz com tanta perfeição, mas que foi super valorizado fora, e nós não valorizamos, então quer dizer, não é só a questão do prédio, mas é uma questão de cultura, uma questão da valorização da sociedade como um todo, porque a gente entende que falta isso, e isso vem da sala de aula, vem da escola, porque se a gente não passar é...Estudos Amazônicos e até mesmo em História, a importância de se valorizar o que é nosso, a gente vai ter uma preocupação...Vai continuar valorizando as coisas de fora, vai continuar valorizando o que vem do Estados Unidos, o que que a mídia, inclusive, que vem do Rio de Janeiro e São Paulo...E aqui não se valoriza" (Professor D). 
O professor $\mathrm{D}$ tem um sonho de construir um memorial dentro da Escola Frei Ambrósio para contar toda a história desde a época da Fortaleza até os dias atuais. É desejo desse professor retornar os canhões para junto da Escola, pois estes estão em locais que não têm ligação direta com a história da cidade.

Acerca da memória citada pelo professor, a Superintendência do IPHAN da Paraíba (2011, p. 55) postula que "é a capacidade de perceber e reunir às experiências, os saberes, as sensações, as emoções, os sentimentos que, por um motivo ou outro, escolhemos para guardar". Meneses (2012, p. 30) endossa o debate afirmando que "lidar com a memória é entendê-la em sua construção, tendo a consciência de que ela é devir, é processo dinâmico e em andamento, é opção temporal, é representação social, é busca de inserção identitária".

O professor entende também que falta conhecimento acerca dos bens patrimoniais tanto pelos alunos como também dos próprios moradores da cidade. Ele cita alguns Patrimônios Edificados que precisam de uma maior atenção, pois são muito importantes para a História, Cultura, Identidade e Memória da cidade.

Para o IPHAN (2012, p. 7- 8)

As pessoas de cada grupo social compartilham histórias e memórias
coletivas, visões de mundo e modos de organização social próprios. Ou seja,
as pessoas estão ligadas por um passado comum e por uma mesma língua,
por costumes, crenças e saberes comuns, coletivamente partilhados. A
cultura e a memória são elementos que fazem com que as pessoas se
identifiquem umas com as outras, ou seja, reconheçam que têm e partilham
vários traços em comum. Nesse sentido, pode-se falar da identidade cultural
de um grupo social.

Se o conhecimento desses bens patrimoniais não chega ao aluno, ao morador fica difícil de garantir a preservação e conservação, haja vista não remeterem a estes sujeitos a algo que faz parte de sua história, identidade e memória, algo que é seu. O professor $D$ enfatizou também a importância da valorização do Patrimônio vivo da cidade como a artesã Dica Frazão.

Para os professores os Patrimônios Edificados no Centro Histórico de Santarém estimulam o Turismo na cidade, porém ainda falta muita coisa para que esses Patrimônios possam ser conhecidos e valorizados tanto pelos alunos como por moradores e turistas.

Vale ressaltar que nenhum Patrimônio (material ou imaterial) em Santarém é tombado pelo IPHAN ou tem a salvaguarda pelo município. 
Sobre a importância dos bens patrimoniais e o estímulo ao Turismo $\mathrm{O}$ Professor E afirmou que:

Com certeza, muitos turistas que vem a cidade eles querem ver, conhecer a história da cidade e os patrimônios, eles fazem parte da história da cidade se não existir os patrimônios como eles conhecerão, como eles saberão? Então é um dos grandes atrativos para o turismo com certeza é a existência desses prédios antigos que na cidade ainda existem". (Professor E)

Através da fala do depoente, pode-se dizer que os Patrimônios servem como referencial da História, Memória e Identidade e são motivos de atração dos turistas para Santarém, pois carregam grande carga de simbologia, informações e características particulares da história local.

Os Patrimônios Edificados antes de serem valorizados pelos turistas tem que ser pelo morador de Santarém. Os alunos sensibilizados, dotados de conhecimento sobre sua história no âmbito local e universal, cultura, identidade e memória podem se tornar turistas cidadãos e replicarem essa postura para o meio em que vivem, pois como afirma Fernanda Sant'Anna

\begin{abstract}
A Educação Patrimonial não deve trabalhar apenas no fomento à valorização da cultura de uma determinada comunidade para demonstrar a importância de seu momento atual, ou ainda a importância da compreensão dos novos significados apropriados às práticas e símbolos. É imprescindível que se busque a compreensão dos aspectos que levaram a construção da mesma, transformando esta reflexão em um exercício de conscientização quanto aos motivos que levaram à necessidade de ressignificação ou manutenção da cultura. Deste modo, se torna possível o entendimento quanto ao valor agregado àquele bem material tombado, àquele saber fazer preservado ou, ainda, quanto aos significados dos ditos populares relacionados ao local de residência daquela comunidade. Além disso, tornase capaz o entendimento de determinadas mudanças, semelhanças e diferenças nas formas de viver dos diversos grupos sociais. (SANT'ANNA, 2015, p. 40)
\end{abstract}

Através da Educação Patrimonial percebe-se ser possível desenvolver práticas pedagógica que proporcionem aos seres humanos um olhar de estranhamento sobre os bens patrimoniais de uma forma crítica - um olhar que possibilitará conhecimento sobre a história, memória e culturas que os suportes patrimoniais representam, enfim é possível ao sujeito apropriar-se de sua cultura e, por conseguinte, este tornar-se turista de seu próprio local, um turista cidadão. 


\section{CONSIDERAÇÕES FINAIS}

Ao término desta dissertação, podemos nos arriscar a tecer algumas considerações sobre Educação Patrimonial e as interfaces que este assunto realiza com outras categorias como História, Cultura, Patrimônio, Memória, Identidade, Cidadania, Educação e Turismo.

Por ser inter e transdisciplinar ela dialoga com estes assuntos, ora citados, numa espécie de simbiose, afinal para que haja Educação Patrimonial é necessário o conhecimento e apropriação dos bens culturais onde estão contidos a História, Cultura, Patrimônio, Memória e Identidade. Sobre o Patrimônio Rosario (2006, p. 87) infere "ajuda a fortalecer a memória do indivíduo, e a valorização por parte deste acontece quando ele identifica e reconhece a importância e representação deste bem cultural para sua vida e a história do seu lugar".

Portanto, na contemporaneidade a Educação Patrimonial é um tema que precisa ser estudado nas escolas desde as séries iniciais até o término do ensino médio para que os alunos tenham desde cedo à consciência e sensibilização da conservação e preservação dos bens patrimoniais sejam eles tangíveis ou intangíveis. Dessa forma, mesmo não fazendo parte do currículo obrigatório, ela pode ser trabalhada na sala de aula e fora dela, a partir do momento em que o patrimônio cultural faça parte do cotidiano dos alunos.

O Turismo precisa da Educação Patrimonial para se desenvolver de forma harmoniosa entre visitantes e visitados. Uma comunidade consciente de seus valores culturais, educada para os bens patrimoniais poderá receber melhor e com informações preciosas sobre sua história, cultura, identidade e memória. Nesse sentido Cabral (2012, p. 39) entende "a educação, como uma prática para a cidadania e, simultaneamente, como formadora de indivíduos críticos, criativos e autônomos, capazes de agir no seu meio e transformá-lo".

A percepção que os alunos do Ensino Fundamental da Escola Frei Ambrósio têm de Educação Patrimonial ainda precisa ser trabalhada pelos professores no sentido de esclarecer o que ela é, pois apesar de os mesmos a praticarem no cotidiano da escola, não têm a consciência disso. Falta o esclarecimento formal enquanto componente do Projeto Político Pedagógico do que é Educação Patrimonial e sua importância para a preservação e conservação dos bens patrimoniais. 
Para que a Educação Patrimonial seja melhor trabalhada, debatida e esclarecida no processo de ensino aprendizagem entre professores e educandos, se faz necessária sua formalização no PPP da Escola, enquanto componente vital na formação para a cidadania. Para isso, o fazer pedagógico sobre a Educação Patrimonial deve alinhar teoria e prática e provocar o conhecimento crítico e criativo sobre os bens patrimoniais que fazem parte do cotidiano das pessoas e que, por conseguinte, são constituintes de suas identidades.

O Patrimônio para a maioria dos alunos é visto com a ideia de posse, pertencimento, algo que se adquire, herança, o que está de acordo com a concepção inicial/antiga de Patrimônio. Diferente da concepção moderna, muito mais ampla e polissêmica - Patrimônio vivo.

Em relação ao Centro Histórico de Santarém e todo o seu acervo patrimonial edificado os alunos conhecem alguns deles como a Igreja Matriz de Nossa Senhora da Conceição, O Centro Cultural João Fona, O Museu Dica Frazão, O Mirante do Tapajós e reconhecem a Escola onde estudam como bem patrimonial e importância para a educação na cidade. Talvez porque estes Patrimônios Edificados estejam bem próximos ao cotidiano deles, por isso foram lembrados em detrimento de outros tão importantes quanto.

Os Patrimônios Edificados do Centro Histórico são trabalhados sim pelas disciplinas afins como História, Estudos Amazônicos, Artes e Educação Artística e também através dos Projetos desenvolvidos pela Escola e ações que envolvam a história da Escola e sua importância para a educação, mas ainda não são reconhecidos como parte de um processo de Educação Patrimonial nos documentos que norteiam as práticas pedagógicas dos professores.

O Patrimônio Histórico de Santarém é rico e diversificado, porém encontra-se negligenciado há anos pelo poder público e por vezes até pela Universidade como foi frisado por um dos professores entrevistados. Por outro lado, existem sujeitos históricos que não concordam com esse cenário de descaso e que cobram providências junto aos órgãos competentes como foi relatado no primeiro capítulo desta dissertação.

A cidadania é assunto muito difundido na Escola Frei Ambrósio e o Projeto Sol Cidadão Legal que trata quase que especificamente sobre cidadania já ganhou até um prêmio nacional e está levando para outras cidades suas ações como a Peça "O Alto da Barca do Fisco", recentemente apresentada na capital, Belém. 
O currículo da Escola Frei Ambrósio é organizado como instrumento de cidadania democrática e contempla conteúdos e estratégias de aprendizagem que capacitem o ser humano para a vida em sociedade, a atividade produtiva e experiência subjetiva. Nessa perspectiva, em consonância com a Organização das Nações Unidas para a Educação, a Ciência e a Cultura - UNESCO tem seus eixos estruturantes da educação na sociedade contemporânea são assim elencados: aprender a conhecer, aprender a fazer, aprender a viver e aprender a ser. A parte diversificada do currículo destina-se a atender às características regionais e locais da sociedade, da cultura [...] (PROJETO POLÍTICO PEDAGÓGICO DA ESCOLA FREI AMBRÓSIO 2014-2015) Dessa forma, o Patrimônio Histórico Cultural de Santarém, Cidadania e Educação Patrimonial são temas que são contemplados no PPP da Escola.

A proposta do Projeto de Guias de Turismo Mirins para a Escola Frei Ambrósio é uma ação que poderá disseminar muitos conhecimentos acerca do Turismo e toda a sua cadeia produtiva, bem como contribuir para o fortalecimento de conhecimentos sobre a história da escola e sua importância enquanto Patrimônio Edificado e para a educação na cidade. Além desse projeto, os demais desenvolvidos na escola permitem aos alunos a reapropriação da cidade e a ressignificação do olhar desses. Um olhar que é próprio ao cidadão, um cidadão que no processo de interação com outros sujeitos se apropria do lugar em que vive, não simplesmente o habita. Esse olhar é capaz ver o que não é visível, de reiterar o visível, permitindo a valorização do espaço e, por conseguinte, promover ações que possibilitem a insurgência de praticas social.

$\mathrm{Na}$ medida em que o aluno experimenta práticas incentivadas e propostas pela Educação Patrimonial ele se torna capaz tanto de apreender dinamicamente o patrimônio bem como a praticar o Turismo de forma cidadã.

É a partir da experiência vivenciada por esses indivíduos, no caso desse estudo, professores e alunos da Escola Estadual de Ensino Fundamental e Médio Frei Ambrósio, que se verifica ser possível a ocorrência das mudanças sociais e culturais. Assim a experimentação da Educação Patrimonial surge como o caminho que leva em direção ao ambiente físico e social no qual ela se coloca como um instrumento de preservação e fomento à cultura, portanto ela é pratica essencial ao desenvolvimento do Turismo Cidadão. 
O entendimento do Turismo pode ser alcançado através da investigação e análise da integração entre as praticas culturais vividas pelos indivíduos no processo de Educação Patrimonial e na prática do Turismo cidadão, haja vista ser o Turista Cidadão capaz de perceber e partilhar a experiência turística com outros sujeitos. 


\section{REFERÊNCIAS BIBLIOGRÁFICAS}

ABREU, Carina Vasconcellos. Conceito de Turista Cidadão na Ação Viva o Centro a Pé em Porto Alegre. Caxias do Sul - UCS, 2012. Disponível em http://www.ucs.br/ucs/tpIVSeminTur\%20/eventos/seminarios_semintur/semin_tur_7/g t03/arquivos/03/01_46_19_Abreu acesso em 02/03/2015.

ABREU, Regina. A emergência do Patrimônio Genético e a nova configuração do campo do Patrimônio. In: Memória e patrimônio: ensaios contemporâneos. ABREU, Regina e CHAGAS, Mário (Orgs.). 2 ed. Rio de Janeiro: Lamparina, 2009.

ALBERTI, Verena. Manual de história oral. 3ª ed. Rio de Janeiro: FGV, 2005.

ALVES, Kerley Santos. Notas sobre a relação espaço-identidade no turismo. In: BRUSADIN, Leandro Benedini; COSTA, Everaldo Batista; PIRES, Maria do Carmo. (Orgs.) Valor patrimonial e turismo: limiar entre história, território e poder. 1. ed., São Paulo: outras expressões, 2012.

AMORIM, Antônia Terezinha dos Santos. O patrimônio cultural edificado em Santarém. In: Patrimônio cultural e direitos culturais na Amazônia: experiências de pesquisa e gestão. CARVALHO, Luciana Gonçalves. ; MILÉO, Bruno Alberto Paracampo (Orgs.). Santarém: UFOPA, 2012.

ANSARAH, Marília Gomes dos Reis. Políticas de turismo e segmentação de mercado. In: Turismo, políticas e desenvolvimento humano. CERDAN, Lluís Mundet i et al. (Org.). Porto Alegre-RS: Asterisco, 2010.

BOMFIM, Natanael Reis. Patrimônio, turismo e planejamento: formatação de produtos. In: Turismo Cultural: estratégias, sustentabilidade e tendências. CAMARGO, Patrícia de et al. (Orgs.). Ilhéus: Editus, 2009.

BARRETTO, Margarita. Manual de iniciação ao estudo do turismo. 20 ed. Campinas-SP: Papirus, 2012.

BARRETTO, Margarita. Cultura e turismo: discussões contemporâneas. Campinas, SP: Papirus, 2007.

BARRETTO, Margarita. Turismo e Legado cultural: as possibilidades do planejamento. 3. ed. Campinas-SP: Papirus, 2000.

BASTOS, Sênia. Ativação do patrimônio nas práticas de hospitalidade. In: BRUSADIN, Leandro Benedini; COSTA, Everaldo Batista; PIRES, Maria do Carmo. (Orgs.) Valor patrimonial e turismo: limiar entre história, território e poder. 1. ed., São Paulo: outras expressões, 2012.

BAUMAN, Zygmunt. A cultura no mundo líquido moderno. Rio de Janeiro: Zahar, 2013. 
BAUMAN, Zygmunt. Ensaios sobre o conceito de cultura. Rio de Janeiro: Zahar, 2012.

BAUMAN, Zygmunt. Identidade. Rio de Janeiro: Zahar, 2005.

BAUMAN, Zygmunt. A modernidade líquida. Rio de Janeiro: Zahar, 2001.

BENI, Mário Carlos. Análise Estrutural do Turismo. São Paulo: Senac, 2008.

BOSEMBECKER, Ângela. Reabilitação de centros e bairros antigos: a importância do patrimônio cultural para os moradores locais. In: CERQUEIRA, Fábio Vergara et al. Educação Patrimonial: perspectivas multidisciplinares. Pelotas: editora da UFPel, 2008.

BOSI, Alfredo. Fenomenologia do olhar. In: O olhar. NOVAES, Adauto (Org.) São Paulo: Companhia das Letras, 1998.

BOSI, Alfredo. Dialética da colonização. São Paulo: Companhia das Letras, 1992.

BOSI, Alfredo. Cultura como Tradição, In: Cultura Brasileira: Tradição Contradição. Rio de Janeiro: Zahar/Funerte, 1987.

BRAGA, Emanuel Oliveira. Memória, Patrimônio e Cidade. In: Educação Patrimonial: orientações ao professor. Superintendência do IPHAN na Paraíba. João Pessoa: IPHAN, 2011.

BRASIL. MINISTÉRIO DO TURISMO. Plano Nacional de Turismo 2013-2016. Brasília, DF, 2013.

BRASIL. MINISTÉRIO DO TURISMO. Turismo cultural: orientações básicas. I Ministério do Turismo, Secretaria Nacional de Políticas de Turismo, Departamento de Estruturação, Articulação e Ordenamento Turístico, Coordenação-Geral de Segmentação. - 3. ed.- Brasília: Ministério do Turismo, 2010.

BRASIL. MINISTÉRIO DO TURISMO. Estudo de Competitividade dos 65 Destinos Indutores do Desenvolvimento Turístico Regional - Relatório Brasil. 2 ed. Brasília: MTur, 2008.

BRASIL. MINISTÉRIO DO TURISMO. Marcos conceituais. Brasília: MTur. MTUR. Marcos Conceituais. Disponível em: http://www.turismo.gov.br/export/sites/default/turismo/o_ministerio/publicacoes/downl oads_publicacoes/Marcos_Conceituais.pdf Acesso em 04 de março de 2013.

BRUSADIN, Leandro Benedini. O Turismo e a História sob a ótica do Patrimônio Cultural: interlocuções entre os campos do saber, práticas e representações In: Patrimônio Cultural: políticas e perspectivas de preservação no Brasil. CHUVA, Márcia; NOGUEIRA, Gilberto Ramos. Rio de Janeiro: Mauad X, 2012.

BURNS, Peter M. Turismo e antropologia: uma introdução. São Paulo: Chronos, 2002. 
CABRAL, Magaly. Educação Patrimonial x Educação Museal? In: Educação Patrimonial: reflexões e práticas. TOLENTINO, Átila Bezerra (Org.) João Pessoa: IPHAN, 2012.

CANCLINI, Nestor Garcia. Culturas híbridas: estratégia para entrar e sair da modernidade. 4 ed. São Paulo: Edusp, 2006.

CARDOSO, Sérgio. O olhar viajante (Do etnólogo). In: O olhar. NOVAES, Adauto (Org.) São Paulo: Companhia das Letras, 1998.

CARNEIRO, Moaci Alves. LDB fácil: leitura crítico-compreensiva: artigo a artigo. Petrópolis - RJ: Vozes, 1998.

CARVALHO, José Murilo de. Cidadania no Brasil: o longo caminho. 3 ed. Rio de Janeiro: Civilização Brasileira, 2002.

CARVALHO, Luciana Gonçalves. Materialidade e imaterialidade na cultura do patrimônio cultural em Santarém. In: Patrimônio cultural e direitos culturais na Amazônia: experiências de pesquisa e gestão. CARVALHO, Luciana Gonçalves. ; MILÉO, Bruno Alberto Paracampo (Orgs.). - Santarém: UFOPA, 2012.

CERDAN, Lluís Mundet i; RAMOS, Silvana Pirillo. Turismo, políticas e desenvolvimento humano. Porto Alegre-RS: Asterisco, 2010.

CERQUEIRA, Fábio Vergara et al. Educação Patrimonial: perspectivas multidisciplinares. Pelotas: editora da UFPel, 2008.

CERQUIER-MANZINI, Maria de Lourdes. O que é cidadania. 4 ed. São Paulo: Brasiliense, 2013.

CHAGAS, Mário. Memória política e política de memória. In: Memória e patrimônio: ensaios contemporâneos. ABREU, Regina e CHAGAS, Mário (Orgs.). 2 ed. Rio de Janeiro: Lamparina, 2009.

CHAUI, Marilena. Janela da alma, espelho do mundo. In: O olhar. NOVAES, Adauto (Org.) São Paulo: Companhia das Letras, 1998.

CHOAY, Françoise. A alegoria do patrimônio. Tradução de Luciano Viera Machado. 3. ed. São Paulo: Estação Liberdade: UNESP, 2006.

COUTO, Estefany Miléo de. Casarões históricos de Santarém: estudo sobre os sobrados e prédios históricos e sua significação dentro da área central da cidade de Santarém. Dissertação de Mestrado. UFPA, 2013.

CONSTITUIÇÃO DA REPÚBLICA FEDERATIVA DO BRASIL. Brasília: Senado Federal, 2006.

COSTA, Everaldo Batista; SCARLATO, Francisco Capuano. Patrimônio da humanidade: universalismo de um apoderamento territorial soberano. In: 
BRUSADIN, Leandro Benedini; COSTA, Everaldo Batista; PIRES, Maria do Carmo. (Orgs.) Valor patrimonial e turismo: limiar entre história, território e poder. 1. ed., São Paulo: outras expressões, 2012.

CUCHE, Denys. A noção de cultura nas ciências sociais. 2 ed. Bauru: EDUSC, 2002.

CUCHE, Denys. A noção de cultura nas ciências sociais. Bauru: EDUSC, 1999.

CURY, Isabelle. Cartas patrimoniais. 3 ed. Rio de Janeiro: IPHAN, 2004.

DE LA TORRE, Oscar. El Turismo: fenómeno Social. México: Fondo de Cultura Econômica, 1992.

DEMO, Pedro. Educar pela pesquisa. 9 ed. Campinas: Editores Associados, 2011.

DIAS, Karina e Silva; MELO, Mariana Inocêncio Oliveira. Parque Farroupilha, a natureza na cidade: práticas de lazer e turismo cidadão. Revista de Turismo Contemporâneo - RTC, Natal, v. 2, n. 1, p. 1-26, jan./jun. 2014. Disponível em http://www.periodicos.ufrn.br/turismocontemporaneo/article/view/5472. Acesso em 21/06/2014.

DIAS, Guilherme; SOARES, André Luis Ramos. Educação Patrimonial e educação popular: um viés possível. In: SOARES, André Luis Ramos; KLAMT, Sérgio Célio (Orgs.). Educação patrimonial: teoria e prática. Santa Maria: Editora UFSM, 2007.

DIAS, Reinaldo. Fundamentos do Turismo: conceitos, normas e definições. Campinas - SP: Alínea, 2002.

DUARTE, Luiz Fernando Dias. Memória e reflexividade na cultura ocidental. In: Memória e patrimônio: ensaios contemporâneos. ABREU, Regina e CHAGAS, Mário (Orgs.). 2 ed. Rio de Janeiro: Lamparina, 2009.

DELGADO, Lucilia de Almeida Neves. História oral: memória, tempo, identidades. 2 ed. Belo Horizonte: Autêntica, 2010.

DENCKER, Ada de Freitas Maneti. Valor Patrimonial: memória social e poder. In: BRUSADIN, Leandro Benedini; COSTA, Everaldo Batista; PIRES, Maria do Carmo. (Orgs.) Valor patrimonial e turismo: limiar entre história, território e poder. 1 ed. São Paulo: outras expressões, 2012.

FERREIRA, Luiz Antônio Miguel. Cidadania das crianças, adolescentes e portadores de deficiência e sua implicação nas empresas. http://www.unifae.br/publicacoes/pdf/revista_da_fae/fae_v7_n2/rev_fae_v7_n2_05.p df acessado em 10/05/2015.

FIGARELLA, Jana. Nada se Compara. In: Letras de Músicas. disponível em: http://letras.mus.br/jana-figarella/1032766/ 
FLORÊNCIO, Sônia Regina Rampim. Educação Patrimonial: um processo de mediação. In: Educação Patrimonial: reflexões e práticas. TOLENTINO, Átila Bezerra (Org.) João Pessoa: IPHAN, 2012.

FONSECA, Maria Cecília Londres. Patrimônio Cultural e Imaterial: para saber mais. 3 ed. Brasília: IPHAN, 2012.

FONSECA, Maria Cecília Londres. Para além da pedra e cal: por uma concepção ampla de patrimônio cultural. In: Memória e patrimônio: ensaios contemporâneos. ABREU, Regina e CHAGAS, Mário (Orgs.). 2 ed. Rio de Janeiro: Lamparina, 2009.

FONSECA, Maria Cecília Londres. O patrimônio em processo: trajetória da política federal de preservação no Brasil. Rio de Janeiro: UFPJ, 1997.

FONSECA, Wilde Dias da. Santarém: logradouros públicos. Santarém: ICBS, 2007.

FONSECA, Wilde Dias da. Santarém: momentos históricos. 4 ed. Santarém: gráfica e editora Tiagão, 1996.

FONSECA, Wilson. Meu baú mocorongo. Belém: SECULT/SEDUC, vol. 02, 2006.

FREIRE, Doia; PEREIRA, Lígia Leite. História oral, memoria e turismo cultural. In: MURTA, S. M.; ALBANO, C. (Orgs). Interpretar o patrimônio: um exercício do olhar. Belo horizonte: Ed UFMG. Território Brasilis, 2002.

FREIRE, Paulo. Pedagogia da autonomia: saberes necessários à prática educativa. São Paulo: Paz e Terra, 2011.

FREIRE, Paulo. Pedagogia do oprimido. Rio de Janeiro: Paz e Terra, 2005.

FUNARI, Pedro Paulo Abreu; PELEGRINI, Sandra de Cássia Araújo. Patrimônio histórico e cultural. 2 ed. Rio de Janeiro: Jorge Zahar, 2009.

FUNARI, Pedro Paulo Abreu; PELEGRINI, Sandra de Cássia Araújo. Patrimônio histórico e cultural. Rio de Janeiro: Jorge Zahar, 2006.

GADOTTI, Moacir; Romão, José E. Autonomia da escola: princípios e propostas. (Org.) 7 ed. São Paulo: Cortez, 2012.

GADOTTI, Moacir. Escola Cidadã. 13 ed. São Paulo: Cortez, 2010.

GASTAL, Susana; MOESCH, Marutschka. Turismo, políticas públicas e cidadania. São Paulo: Aleph, 2007.

GASTAL, Susana. Turismo, imagens e imaginários. São Paulo: Aleph, 2005.

GASTAL, Susana. Lugar de memória: por uma nova aproximação teórica ao patrimônio local. In: Turismo Investigação e crítica. GASTAL, Susana et al. (Org.) São Paulo: Contexto, 2002. 
GASTAL, Susana. O produto cidade: caminhos de cultura, caminhos de turismo. In: Turismo Urbano. CASTROGIOVANNI, Antonio Carlos (Org.). São Paulo: Contexto, 2000.

GEERTZ, Clifford. A Interpretação das culturas. Rio de Janeiro: LTC, 1989.

GONÇALVES, José Reginaldo Santos. O patrimônio como categoria de pensamento. In: Memória e patrimônio: ensaios contemporâneos. ABREU, Regina e CHAGAS, Mário (Orgs.). 2 ed. Rio de Janeiro: Lamparina, 2009.

GONÇALVES, José Reginaldo Santos. Ressonância, materialidade e subjetividade: as culturas como patrimônio. In: Antropologia dos objetos: coleções, museus e patrimônios. Rio de Janeiro, 2007. Disponível em http://naui.ufsc.br/files/2010/09/antropologia_dos_objetos_V41.pdf acesso em 04/03/2014.

GENTILLI. Victor. Democracia de massas, jornalismo e cidadania: estudo sobre as sociedades contemporâneas e o direito dos cidadãos à informação. Porto Alegre: EDIPUCRS, 2005.

GOODEY, B. Turismo Cultural: novos viajantes, novas descobertas. In: MURTA, S. M.; ALBANO, C. (orgs). Interpretar o Patrimônio: um exercício do olhar. Belo horizonte: Ed UFMG. Território Brasilis, 2002.

GRUNBERG, Evelina. Manual de atividades práticas de educação patrimonial. Brasília: IPHAN, 2007.

GUIMARÃES, Iza Vanessa P. de F; SILVA, Antonia Eurenice Rodrigues. De uma Fortaleza a uma forte Escola. 2012.

GUIMARÃES, Solange T. de Lima. Valoração de paisagens: campos de visibilidades e de significâncias. In: In: BRUSADIN, Leandro Benedini; COSTA, Everaldo Batista; PIRES, Maria do Carmo. (Orgs.) Valor patrimonial e turismo: limiar entre história, território e poder. 1 ed. São Paulo: outras expressões, 2012.

HALL, Stuart. A identidade cultural na pós-modernidade. Rio de Janeiro: DP\&A, 2005.

HORTA, Maria de Lourdes Parreiras; GRUNBERG, Evelina; MONTEIRO, Adriane Queiroz. Guia básico de Educação Patrimonial. Brasília: IPHAN; Rio de Janeiro: Museu Imperial, 1999.

INSTITUTO BRASILEIRO DE GEOGRAFIA E ESTATíSTICA (IBGE) Censo Demográfico 2010: Resultados Preliminares da Amostra, [http://www.ibge.gov.br/home/estatistica/populacao/censo2010/resultados_preliminar es_amostra/default_resultados_preliminares_amostra.shtm], (Site acessado em 28 outubro 2013). 
INSTITUTO DO PATRIMÔNIO HISTÓRICO E ARTÍSTICO NACIONAL - IPHAN. Educação Patrimonial: histórico, conceitos e processos. IPHAN: Brasília, 2014.

INSTITUTO DO PATRIMÔNIO HISTÓRICO E ARTÍSTICO NACIONAL - IPHAN. Patrimônio Cultural Imaterial: para saber mais. 3 ed. Brasília: IPHAN, 2012.

INVENTÁRIO DA OFERTA TURISTICA DE SANTARÉM. SECRETARIA MUNICIPAL DE TURISMO DE SANTARÉM - SEMTUR. Santarém: Semtur, 2013.

ITAQUI, José; VILLAGRÁN, Maria Angélica. Educação Patrimonial: a experiência da quarta colônia. Santa Maria: Pallotti, 1998.

JEUDY, Henri-Pierre. Memórias do social. Rio de Janeiro: Forense Universitária, 1990.

KRIPPENDORF, Jost. Sociologia do turismo: para uma nova compreensão do lazer e das viagens. 3. ed. São Paulo: Aleph, 2003.

LAER, Paulina Von. Paisagem urbana contemporânea: preexistência, inovação e patrimônio cultural. In: CERQUEIRA, Fábio Vergara et al. Educação Patrimonial: perspectivas multidisciplinares. Pelotas: editora da UFPel, 2008.

LEBEDEV, Nádia. Olhar pela primeira vez: a percepção do estrangeiro. Revista eletrônica do Programa de Pós-graduação da Faculdade Cásper Líbero. 2010. Disponível em http://www.revistas.univerciencia.org/index.php/comtempo/article/viewFile/7496/6917 . Acesso em 26/05/2015.

LE GOFF, Jacques. História e Memória. Tradução: Bernardo Leitão [et al.]. 5. ed. Campinas, SP: Editora UNICAMP, 2003.

LÉVI-STRAUSS, C. Introduction à 1'oeuvrc de Mareei Mauss. In: MAUS, Mareei, Sociologie et Antropologie. Paris: PUF, 1950.

LIRA, Bruno Carneiro. 0 passo a passo do trabalho científico. 2 ed. Petrópolis-RJ: Vozes, 2014.

LYNCH, Kevin. 2010. A imagem da cidade. Rio de Janeiro: Martins Fontes, 2010.

MACHADO. Maria Beatriz Pinheiro. Educação Patrimonial: orientações para professores do ensino fundamental e médio. Caxias do Sul: Maneco, 2004.

MAFFESOLI, Michel. No fundo das aparências. Petrópolis: Vozes, 1996.

MAGALHÃES, Leandro Henrique. Educação Patrimonial: uma análise conceitual. In: Construção de políticas patrimoniais: ações preservacionistas de Londrina, região norte do Paraná e sul do país. BRANCO, Patrícia Castelo et al. Londrina: Ed UniFil, 2009. 
MARTINS, Clerton. Identidade: percepção e contexto. In: MARTINS, Clerton (org.) Turismo, Cultura e Identidade. São Paulo: Roca, 2003.

MEIHY, José Carlos Sebe B; RIBEIRO, Suzana L. Salgado. Guia prático de história oral: para empresas, universidades, comunidades, famílias. São Paulo: Contexto, 2011.

MEKSENAS, Paulo. Cidadania, poder e comunicação. São Paulo: Cortez, 2002.

MENESES, José Newton Coelho. A patrimonialização da vida: vivências, memória social e interpretação do patrimônio cultural. In: BRUSADIN, Leandro Benedini; COSTA, Everaldo Batista; PIRES, Maria do Carmo. (Orgs.) Valor patrimonial e turismo: limiar entre história, território e poder. 1 ed. São Paulo: outras expressões, 2012.

MOESCH, Marutschka. Epistemologia social do turismo. São Paulo: ECA-USP, 2v. (Tese de Doutorado), 2004.

MOESCH, Marutschka. A produção do saber turístico. 2 ed. São Paulo: Contexto, 2002.

MOESCH, Marutschka. Por uma epistemologia do turismo. São Paulo: Contexto, 2000.

MORIN, Edgar. A cabeça bem-feita: pensar a reforma, reformar o pensamento. 20 ed. Rio de Janeiro: Bertrand Brasil, 2012.

MORIN, Edgar. Os sete saberes necessários à educação do futuro. 2 ed. São Paulo: Cortez, 2011.

NALINI, José Renato. Justiça e cidadania. In: PINSKY, Jaime. Práticas de cidadania. (Org.) São Paulo: Contexto, 2004.

NORA, Pierre. Entre memória e história: a problemática dos lugares. São Paulo, 1993.

NOVAES, Adauto. De olhos vendados. In: O olhar. NOVAES, Adauto (Org.) São Paulo: Companhia das Letras, 1998.

OLIVEIRA, Lúcia Luppi. Cultura é patrimônio: um guia. Rio de Janeiro: FGV, 2008.

OLIVEIRA. Maria Marly de. Como fazer pesquisa qualitativa. Petropólis, RJ: Vozes, 2007.

OLIVEIRA, Fabiana; WENCESLAU, Franclin Ferreira. Educação Patrimonial e a pesquisa arqueológica no Sítio Casa de Davi Cababarro em Santana do Livramento-RS. In: SOARES, André Luis Ramos; KLAMT, Sérgio Célio (Orgs.). Educação patrimonial: teoria e prática. Santa Maria: Editora UFSM, 2007. 
ORGANIZAÇÃO MUNDIAL DO TURISMO - OMT. Introdução ao Turismo. São Paulo: Roca, 2001.

PEREGRINO, Umbelino. Patrimônio Cultural: uma construção da cidadania. In: TOLENTINO, Átila (Org.). Educação Patrimonial: reflexões e práticas. João Pessoa: IPHAN, 2012.

PEREIRA, José Carlos Matos. Importância e Significado das Cidades Médias na Amazônia: Uma abordagem a partir de Santarém (PA) - Belém: NAEA/UFPA, Dissertação (Mestrado) - Universidade Federal do Pará, Núcleo de Altos Estudos Amazônicos, Pós-Graduação em Desenvolvimento Sustentável do Trópico Úmido, 2004.

PESAVENTO, Sandra Jatahy. História \& História Cultural. Belo Horizonte: Autêntica, 2012.

PESAVENTO, Sandra Jatahy. História, literatura e cidades: diferentes narrativas para o campo do patrimônio. (in) Revista do patrimônio histórico e artístico nacional $n^{\circ}$ 34. Brasília: IPHAN, 2012.

PESAVENTO, Sandra Jatahi. O Imaginário da Cidade, Visões Literárias do Urbano: Paris, Rio de Janeiro, Porto Alegre. Rio Grande do Sul: Editora Universidade: UFRGS, 1999.

PINSKY, Jaime. Práticas de cidadania. (Org.) São Paulo: Contexto, 2004.

PINSKY, Jaime ; PINSKY, Carla Bassanezi (Orgs). História da Cidadania. $2^{\mathrm{a}}$ Ed. São Paulo: Contexto, 2003.

PINTO, Lucio Flávio. Eu sou Amazônida e você? Disponível em http://www.acessa.com/gramsci/?id=514\&page=visualizar acesso em 11/05/2015

PLANO DE AÇÃO DAS CIDADES HISTÓRICAS SANTARÉM - PARÁ 2010/2013, 2010.

POULOT, Dominique. Uma história do patrimônio no ocidente. São Paulo: estação liberdade, 2009.

PROJETO POLÍTICO PEDAGÓGICO DA ESCOLA ESTADUAL DE ENSINO FUNDAMENTAL E MÉDIO FREI AMBRÓSIO 2014/2015.

REGO. T. C. Vygotski: Uma perspectiva histórico-cultural da educação. Petrópolis-RJ, 1995.

REIS, Arthur Cezar Ferreira. Santarém: seu desenvolvimento histórico. Rio de Janeiro: Civilização Brasileira, 1979.

REVISTA PATRIMÔNIO HISTÓRICO DE SANTARÉM. Faculdades Integradas do Tapajós, 2010. 
RODRIGUES, Marly. Preservar e Consumir: o patrimônio histórico e o turismo. In: FUNARI, Pedro Paulo; PINSKY, Jaime (org.) Turismo e Patrimônio Cultural. 3. ed. São Paulo: Contexto,2003.

ROSARIO, Edson Antonio Costa do. Educação Patrimonial na Baixada Fluminense: uma experiência no Centro Integrado de Educação Pública - CIEP 354 Martins Pena. Dissertação de Mestrado. Universidade Federal do Estado do Rio de Janeiro - UNIRIO, Rio de Janeiro, 2006.

SALES, Fabiana Lima. Educação Patrimonial e o Turismo: o caso da aula no museu municipal de Caxias do Sul. Dissertação de Mestrado, Caxias do Sul: UCS, 2006.

SANT ANNA, Fernanda da Silva. Educação Patrimonial e a formação do Turista Cidadão: um estudo de caso sobre o Projeto Re (vi) vendo Êxodos. Dissertação de Mestrado CET/UnB, Brasília, 2015.

SANT'ANNA, Marcia. A face imaterial do patrimônio cultural: os novos instrumentos de reconhecimento e valorização. In: Memória e patrimônio: ensaios contemporâneos. ABREU, Regina e CHAGAS, Mário (Orgs.). 2 ed. Rio de Janeiro: Lamparina, 2009.

SANTIAGO, Maria do Socorro de Farias. Pelos caminhos do Sairé: um estudo do aproveitamento da cultura popular no teatro-educação. São Paulo, 1996. Tese de Doutorado. Escola de Comunicações e Artes da Universidade de São Paulo.

SANTOS, Paulo Rodrigues. Tupaiulândia. Santarém: ICBS/ACN, 1999.

SANTOS, Milton. O espaço do Cidadão. 7 ed. São Paulo: Edusp, 2007.

SEABRA, Halisson Cardoso; TABOSA, Flora Queiroga. História e Turismo unidos pela Educação Patrimonial: análise do projeto "o futuro visita o passado". In: Educação Patrimonial: reflexões e práticas. TOLENTINO, Átila Bezerra (Org.) João Pessoa: IPHAN, 2012.

SCIFONI, Simone. Educação Patrimonial Cultural: reflexões sobre o tema. In: Educação Patrimonial: reflexões e práticas. TOLENTINO, Átila Bezerra (Org.) João Pessoa: IPHAN, 2012.

SECRETARIA MUNICIPAL DE MEIO AMBIENTE DE SANTARÉM. CENTRO DE INFORMAÇÕES AMBIENTAIS - CIAM. Informações municipais de Santarém. Santarém: Semma/Ciam, 2013.

SOARES, André Luis Ramos; KLAMT, Sérgio Célio (Orgs.). Educação patrimonial: teoria e prática. Santa Maria: Editora UFSM, 2007.

SOARES, André Luis Ramos. Educação Patrimonial: relatos e experiências et al. Santa Maria: UFSM, 2003. 
SOUZA, Duílio Duka de. Combate ao racismo: compromissos e ações propositivas. In: PINSKY, Jaime. Práticas de cidadania. (Org.) São Paulo: Contexto, 2004.

SUPERINTENDÊNCIA DO IPHAN NA PARAÍBA. Educação Patrimonial: orientações ao professor. João Pessoa: IPHAN, 2011.

TOLENTINO, Átila. Educação, memórias e identidades: enlaces e cruzamentos. In: Educação Patrimonial: educação, memórias e identidades. TOLENTINO, Átila Bezerra (Org.). João Pessoa: IPHAN, 2013.

ULHÔA, Maria Inês Adjuto. Entre carnes e livros: a arte plural de um açougue e sua apropriação como patrimônio cultural. Dissertação de Mestrado CET/UnB, Brasília, 2013.

VILLASCHI, Juca. Requalificação da cidadania pela interpretação sensorial: direito ao patrimônio. In: BRUSADIN, Leandro Benedini; COSTA, Everaldo Batista; PIRES, Maria do Carmo. (Orgs.) Valor patrimonial e turismo: limiar entre história, território e poder. . 1. ed., São Paulo: outras expressões, 2012.

\section{Sites Consultados}

http://www.skyscrapercity.com acesso em 02/07/2014

http://www.ignaccioneto.blogspot.com.br acesso em 10/11/2014

http://www.blogdojeso.com.br acesso em 04/05/2014

http://www.paraturismo.pa.gov.br acesso em 05/06/2014

http://www:macedoelivaldo.blogspot.com.br acesso em 08/01/2015

http://www.facebook.com/1417217595160969/photos/pb.1417217595160969.2207520000.1420744917./1417221748493887/?type=3\&theater acesso em $08 / 01 / 2015$

http://www.historiacsd.blogspot.com.br/2010/11/arqueologia-amazonica-fazendataperinha.html acesso em 08/01/2015

http://www.g1.globo.com/pa/para/noticia/2014/09/carimbo-do-pa-e-declaradopatrimonio-cultural-imaterial-do-brasil.html acesso em 14/01/2015

http://www.saire.pa.gov.br acesso em 10/05/2014

http://www.mansardas.blogspot.com.br/2013/11/d-dica-frazao acesso em 16/01/2015 http://www.museus.gov.br/tag/museu-dica-frazao acesso em 02/02/2014 
http://www.premioeducacaofiscal.com.br acesso em 08//08/2014

http://www.googleEarth.com.br acesso em 20/08/2014

http://www.tripadvisor.com.br/Attraction_Review-g673261-d2406747-Reviews-

Museu_Dica_Frazao-Santarem_State_of_Para.html\#photos acesso em 27/11/2014

https://www.facebook.com/pages/Mais-Educa\%C3\%A7\%C3\%A3o-Escola-FreiAmbrosio/440117336067208?fref=photo acesso em 14/05/2015

http://letras.mus.br/mosaico-de-ravena/268048/ acesso em 22/05/2015 


\section{APÊNDICES}




\section{APÊNDICE 1 \\ TERMO DE CONSENTIMENTO}

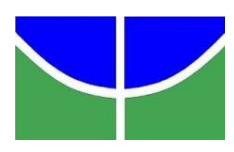

\section{UNIVERSIDADE DE BRASÍLIA \\ CENTRO DE EXCELÊNCIA EM TURISMO \\ PROGRAMA DE MESTRADO PROFISSIONAL EM TURISMO}

Prezado(a) participante:

Sou estudante do curso de Mestrado Profissional em Turismo do Centro de Excelência em Turismo - CET da Universidade de Brasília - UnB. Estou realizando uma pesquisa sob a supervisão da Prof $^{a}$ Dra $^{a}$ Eloísa Pereira Barroso cujo objetivo é Investigar qual a percepção de Educação Patrimonial têm os alunos do Ensino Fundamental e professores da Escola Estadual de Ensino Fundamental e Médio Frei Ambrósio e sua relação para a formação do turista cidadão no Centro Histórico de Santarém-PA.

Sua participação envolve uma entrevista, que será gravada se assim você permitir.

A participação nesse estudo é voluntária e se você decidir não participar ou quiser desistir de continuar em qualquer momento, tem absoluta liberdade de fazê-lo.

Na publicação dos resultados desta pesquisa, sua identidade será mantida no mais rigoroso sigilo. Serão omitidas todas as informações que permitam identificá-lo(a).

Sua participação é muito importante e estará contribuindo para a compreensão do fenômeno estudado e para a produção de conhecimento científico.

Quaisquer dúvidas relativas à pesquisa poderão ser esclarecidas pelo pesquisador Elias Mota Vasconcelos, Mestrando do CET/UnB e-mail: eliasturismo@yahoo.com.br

Atenciosamente

Elias Mota Vasconcelos

Local e data

Matrícula 130084808

Consinto em participar deste estudo e declaro ter recebido uma cópia deste termo de consentimento.

Nome e assinatura do participante

Local e data 


\section{APÊNDICE 2}

TERMO DE CONSENTIMENTO

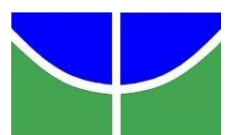

\section{UNIVERSIDADE DE BRASÍLIA CENTRO DE EXCELÊNCIA EM TURISMO PROGRAMA DE MESTRADO PROFISSIONAL EM TURISMO}

Esta entrevista é parte integrante da pesquisa intitulada: Educação Patrimonial na Escola Estadual de Ensino Fundamental e Médio Frei Ambrósio em Santarém-Pa e a formação do Turista Cidadão cujo objetivo geral cujo objetivo geral é Investigar qual a percepção de Educação Patrimonial têm os alunos do Ensino Fundamental e professores da Escola Estadual de Ensino Fundamental e Médio Frei Ambrósio e sua relação para a formação do turista cidadão no Centro Histórico de Santarém-PA.

1. Nome:

2. Endereço:

3. Telefone:

4. Idade:

5. Série:

6. Para você o que é Patrimônio?

7. E Educação Patrimonial?

8. Você conhece os Patrimônios Edificados de Santarém?

9. Se sim, qual a importância deles para os moradores e turistas em Santarém?

10. Você considera a Escola Frei Ambrósio um patrimônio?

11. Você sabe o que é Cidadania?

12. Para você o que é Turismo?

13. Já ouviu falar em Turista Cidadão?

14. Já participou de alguma ação, projeto, estudo, oficina sobre Educação Patrimonial aqui na escola? 


\section{APÊNDICE 3 \\ TERMO DE CONSENTIMENTO}

\section{UNIVERSIDADE DE BRASÍLIA CENTRO DE EXCELÊNCIA EM TURISMO PROGRAMA DE MESTRADO PROFISSIONAL EM TURISMO}

Esta entrevista é parte integrante da pesquisa intitulada: Educação Patrimonial na Escola Estadual de Ensino Fundamental e Médio Frei Ambrósio em Santarém-Pa e a formação do Turista Cidadão cujo objetivo geral é Investigar qual a percepção de Educação Patrimonial têm os alunos do Ensino Fundamental e professores da Escola Estadual de Ensino Fundamental e Médio Frei Ambrósio e sua relação para a formação do turista cidadão no Centro Histórico de Santarém-PA.

Nome/idade:

Formação Acadêmica:

Disciplina Ministrada:

Tempo de serviço na escola:

1. Professor (a), o Patrimônio Histórico de Santarém, nossa cultura, cidadania são temas abordados na disciplina ministrada pelo senhor (a)? Se sim, de que forma?

2. O senhor (a) já ouviu falar em Turista Cidadão?

3. Qual seu entendimento sobre Educação Patrimonial?

4. O senhor (a) conhece alguma ação, projeto, oficina que envolva cidadania, educação patrimonial na escola Frei Ambrósio?

5. Qual sua opinião sobre os Patrimônios Edificados no Centro Histórico de Santarém? 
ANEXOS 


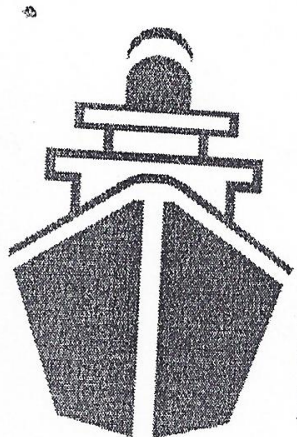

E

NAVIO

SEABOURN QUEST

SEABOURN QUEST

REGATTA

PRINSENDAM

SILVER WHISPER

SEVEN SEAS NAVIGATOR

PRINSENDAM

SEVEN SEAS NAVIGATOR

SILVER WHISPER

INSIGNIA

HAMBURG

HAMBURG

INSIGNIA

HAMBURG

HAMBURG

MARCO POLO

MARCO POLO

ADONIA

SILVER CLOUD

SILVER CLOUD

PRINSENDAM

MAASDAM

MAASDAM

SEABOURN QUEST

REGATTA

REGATTA

SEABOURN QUEST

BREMEN

HANSEATIC

BREMEN

CRYSTAL SERENITY

CRYSTAL SERENITY

HANSEATIC
MC - NÁUTICA EQUIPAMENTOS NAVAIS LTDA.

Corrêa

Avenida Tapajós, $n^{\circ} 1825$ - Aldeia.

FAX: (093) 3523-1576

CEP:68040-000 - SANTAREM-PARA-BRASIL

E-MAIL: manuel.neto@yahoo.com.br

\section{RA}

\section{ESCALA \\ SANTARÉM \\ SANTARÉM \\ SANTARÉM \\ SANTARÉM \\ SANTARÉM}

SANTARÉM

ALTER DO CHÃO

ALTER DO CHÃO

ALTER DO CHÃO

SANTARÉM

SANTARÉM

ALTER DO CHÃO

ALTER DO CHÃO

ALTER DO CHÃO

SANTARÉM

SANTARÉM

ALTER DO CHÃO

SANTARÉM

SANTARÉM

ALTER DO CHÃO

SANTARÉM

SANTARÉM

ALTER DO CHÃO

SANTARÉM

ALTER DO CHÃO

SANTARÉM

SANTARÉM

ALTER DO CHÃO

ALTER DO CHÃO

ALTER DO CHÃO

ALTER DO CHÃO

SANTARÉM

ALTER DO CHÃO

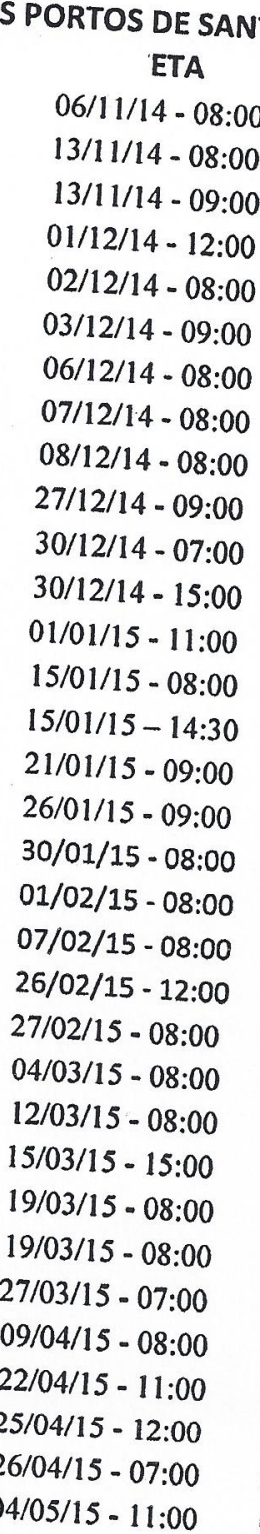

ETA

$06 / 11 / 14-08: 00$

$13 / 11 / 14-08: 00$

$13 / 11 / 14-09: 00$

$02 / 12 / 14-08: 00$

$03 / 12 / 14-09: 00$

$06 / 12 / 14-08: 00$

07/12/14-08:00

27/12/14 - 09:00

30/12/14 - 07:00

$01 / 01 / 15-11: 00$

15/01/15 - 08:00

$15 / 01 / 15-14: 30$

21/01/15 - 09:00

26/01/15 - 09:00

30/01/15 - 08:00

$01 / 02 / 15-08: 00$

07/02/15 - 08:00

26/02/15 - 12:00

27/02/15 - 08:00

04/03/15 - 08:00

12/03/15 - 08:00

$15 / 03 / 15-15: 00$

$19 / 03 / 15-08: 00$

19/03/15 - 08:00

$27 / 03 / 15$ - 07:00

$09 / 04 / 15-08: 00$

$22 / 04 / 15-11: 00$

$25 / 04 / 15-12: 00$

26/04/15 - 07:00

$04 / 05 / 15-11: 00$
08/12/14 - 08:00

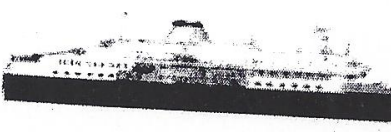

$43 a n o s-1970-2013$
ETS
EO CHÃO DE 06/11/14 A 04/05/15

$06 / 11 / 14-18: 00$

$13 / 11 / 14-18: 00$

13/11/14 - 18:00

$01 / 12 / 14-20: 00$

$02 / 12 / 14-19: 00$

$03 / 12 / 14-18: 00$

$06 / 12 / 14-14: 00$

$08 / 12 / 14-13: 00$

27/12/14 - 18:00

$30 / 12 / 14-12: 30$

$30 / 12 / 14-20: 00$

$01 / 01 / 15-18: 00$

$15 / 01 / 15-12: 00$

15/01/15 - 20:00

$21 / 01 / 15-18: 00$

26/01/15 - 17:00

30/01/15 - 18:00

$01 / 02 / 15-19: 00$

07/02/15 - 13:00

26/02/15 - 20:00

27/02/15 - 18:00

$04 / 03 / 15-17: 00$

12/03/15 - 23:59

$15 / 03 / 15-20: 00$

$19 / 03 / 15-14: 00$

$19 / 03 / 15 \cdot 18: 00$

27/03/15 - 18:00

09/04/15 - 16:00

$22 / 04 / 15-19: 00$

25/04/15 - 18:00

26/04/15 - 16:00

04/05/15 - 19:00
$07 / 12 / 14-14: 00$

ORIGEM
MACAPA
MANAUS
MACAPA
DEVIL'S ISLAN
DEVIL'S ISLA
MACAPA
MANAUS
MANAUS
MANAUS
MACAPA
MACAPA
SANTARÉM
MANAUS
MANAUS
A DO CHÃO

MACAPA

MANAUS

MACAPA

MACAPÁ

MANAUS

MACAPÁ

MACAPÁ

MANAUS

MACAPÁ

MACAPA

MANAUS

MANAUS

BELEM

BELÉM

MANAUS

SALVADOR

A DO CHÃO

MANAUS

\section{DESTINO}

MANAUS

MACAPA

MANAUS

MANAUS

MANAUS

MANAUS

TOBAGO

DEVIL'S ISLAND

MANAUS

MANAUS

DEVIL'SISLAND ISS

SANTARÉM ISS

FRENCH GUYANA ISS

MANAUS

FRENCH GUYANA ISS

MACAPA ISS

MANAUS ISS

MACAPA ISS

MANAUS ISS

MANAUS ISS

ST LUCIA. ISS

MANAUS ISS

MANAUS ISS

MACAPA ISS

MACAPA ISS

MANAUS ISS

MANAUS ISS

BELÉM ISS

SANTAREM ISS

MACAPÁ ISS

BELÉM

S

ISS
BRIDGETOWN

ALTER DO CHÃO
AGÊNCIA

ISS

ISS

ISS

ISS

ISS

ISS

ISS

ISS

SS

SS

\section{SS} ISS ISS . SS S

S

SS

SS
S SS SS 
GOVERNO DO ESTADO DO PARA

SECRETARIA DE ESTADO DO EDUCACAO

ESCOLA ESTADUAL DE ENSINO FUNDAMENTAL E MÉDIO

FREI AMBRÓSIO

PROJETO POLÍTICO PEDAGÓGICO

w

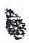

5

楼 


\section{IDENTIFICAÇÃ̃O}

Escola Estadual de Ensino Fundamental e Médio "Frei Ambrósio"

Diretor: Marcos Venício S. Botelho

Vice: Fieriisia Mioreira Pereira

Vice:

Data de Fundação: 03 de Maio de 1900

Clientela atual: 1.029 alunos

Niveis de Ensino e Modalidades de Ensino:

Ensino Fundamental

Ensino Fundamental: $5^{\mathrm{a}}$ a $8^{\mathrm{a}}$ série.

Número de Autorizaçăo da Escola: Ensino Fundamental: REC.AUT. 521/89

Portaria de autorização dos cursos: Ensino Fundariental: № 1334/80 - GS. 01/08/80

Ensino Fundamental: $6^{\circ}$ a $7^{\circ}$, em processo.

\section{Ensino Médio Regular}

Ėnsino Médio Regular: Portaria de autorização №183/96-GS. 02/04/96.

Ensino Médio Regular: $1^{\circ}, 2^{\circ}$ e $3^{9}$, Portaria de autorização REC.AUT. 248/2004

\section{Educação de Jovens e Adultos}

Educação de Jovens e Adultos: Portaria de autorização, № 482/76 - GS. 07/06/76

Educação de Jovens e Adultos Médio: incluithúmero de portaria

\section{Turnos de funcionamento Ano 2014:}

- Turno Matutino

12 turmas sendo:

03 de Ensino Fundamental de $7^{a}$ a $8^{\mathrm{a}}$ séries $6^{\mathrm{a}}, 7^{\mathrm{a}}$ Ano

07 de Ensino Médio, do $1^{9}$ ao $3^{9}$ ano.

- Turno Vespertino

12 turmas sendo:

03 de Ensino Fundamental de $5^{\mathrm{a}}$ a $8^{\mathrm{a}}$ séries $/ 7^{0}$ ano

09 de Ensino Médio do $1^{2}$ ao $3^{9}$ ano

- Turno Noturno

06 turmas sendo:

02 EJA Ensino Médio

03 de Ensino Médio Regular ( $1^{\circ}$ ao $3^{\circ}$ ano) 


\section{MARCO SITUACIONAL}

\section{CARACTERIZAÇÃO DO BAIRRO}

A Escola Frei Ambrósio está situada no bairro central da cidade, onde iininia-se au nutie com o rio Tapajós, ao sui com o bairro Santa Ciara, a leste com o bairn da Prainha e a oeste com o bairro da Aldeia. No mesmo bairro, encontra-se localizado a Escola Estadual de Ensino Médio Rodrigues dos Santos. Polópertencer ao centro. a escola está rodeada de pontos de lazer e atraçoes tai como: Museu João Fona, a Praça Barão de Santarém, a Praça do Pescador, á Orla Fluvial de Santarém, atualmente o "point" da cidade, a praça do Mirante, o Bar Mascote e o Mascotinho, sendo esses, os ambientes mais requisitados pelos cidadãos santarenos nos finais de semana.

Por estar situada no centro da cidade localiza-se próximo de várias instituiçōes privadas como: CREAS, Conselho Tutelar, Secretaria Municipal de Saúde. SESPA, dentre outras.

De acordo com os dados do censo demográfico do IBGE (Instituto Brasileiro de Geografia e Estatística) o bairro apresenta uma população de aproximadamente 1.831 habitantes, sendo domicílios ocupados $496 \mathrm{em}$ uso, incluindo apartamentos. Quanto ao saneamento básico as principais deficiências estão concentradas nos bairrossperiféricos, porém verifica-se que há algumas faltas de medidas práticas de saneamento, pois existe uma rede de esyoto que finaliza seu percurso na orla da cidade no encontro das águas do Tapajós e Amazonas.

Quanto à localizaçăo faz parte da paróquia de Nossa Senhora da Conceição, padroeira dos santarenos, por isso, todas as atividades de cunho religioso săo realizadas nas dependências da referida igreja, assim temos também, outras instituições religiosas próximas da escola tais como: Igreja de São Sebastião, Igreja Universal do Reino de Deus localizada na Praça Barão de Santarém e avenida Rui Barbosa, respectivamente. Encontra-se no bairro presente os mais variados tipos de comércios, como: lojas, magazines, além de grande número de farmácias e bancos. O bairro apresenta muitas pessoas que atuam livremente vendendo determinados produtos como fonte de renda para o sustento de suas famílias, chamados profissionais ambulantes.

O nível socioeconômico da população do bairı centrai, observa-se que é bem elevado, uma vez que, as casas são bem estruturadas e projetadas, existe um grande número de apartamentos que facilitam a vida das pessoas que trabalham no centro do comércio e que ${ }^{6}$ studam a noite nas instituições de nível superior. É um bairro muito movimentado durante a semana, uma vez que encontramos os diferentes tipos de comércio (supermercados, lojas de artigos infanto-juvenis, cama, mesa e banho, butiques, perfumarias e outros). Para que a população tenha mais acesso ao comércio local, os empresários das linhas de transporte coletivo dão uma grande priorijade, onde todos as linhas fazem tráfego, interligando o centro comercial aos demais bairros da cidade, tais como: Conquista, Amparo, Santarenzinho, Prainha, Jaderlândia, Tabocal, Maracanā, Nivva Repúbiica, Cohab, Diamantino, Liberdade, Cucurunã e outros.

Desta forma, pode-se afirmar que há uma boa relação entre a escola e a comunidade, uma vez que a escola completa 112 anos de fundação e por isso, ao redor da escola encontra-se ex-alunos que participam ativamente como amigos da escola, pois sentem-se honrados de terem estudado, na escola mais antiga do município de Santarém. 


\subsection{PRESSUPOSTOS BÁSICOS}

\subsubsection{FILOSOFIA DA ESCOLA}

A Escola deve servir aos interesses da comunidade escolar garantindo a todos um ensino de qualidade, isto é, a apropriação dos conteúdos escolares básicos que tenham relevância na vida dos alunos.

\subsubsection{VISÃ̃O DA ESCOLA}

Ser uma escola de referêneia pela qualidade da ação educativa que desenvolve de forma crítica, participativa e transformadora.

\subsubsection{MISSÃ̃O DÂ ESCOLÂ}

Fornecer ao aluno subsídios para o exercício da cidadania, por meio da aquisição de conteúdos, para uma participação organizada e ativa na democratização da sociedade.

\subsection{OBJETIVOS DA ESCOLA}

\subsubsection{OBJETIVO GERAL}

- Formar cidadãos responsáveis, participativos e críticos para atuarem numa sociedade democrática;

\subsubsection{OBJETIVOS ESPECÍFICOS}

- Aprimorar a qualidade do ensino oferecido aos alunos;

- Capacitar educandos para o exercício das atividades produtivas, aprimoramento das competências e habilidades necessárias para a atuação no. mundo do trabalho e das práticas sociais que o circundam;

- Garantir a inclusão de alunos com necessidades educacionais especiais;

- Buscar soluções ou parcerias para a resolução ou diminuição dos problemas existentes na escola;

- Fazer estatísticas constantes da situação do desempenho escolar dos alunos;

- Proporcionar um bom ambiente de trabalho no intuito de obter melhores resultados

- Oportunizar aos educandos condições de ingressar no ensino médio

- Oferecer aos educandos uma educação que prime pelo sucesso escolar E consciência crítica e todos.

\subsection{METAS DA ESCOLA}

\begin{tabular}{|l|c|c|}
\hline \multicolumn{1}{|c|}{ METAS PLANEIADAS PPP } & $\begin{array}{c}\text { METAS } \\
2013\end{array}$ & METAS2014 \\
\hline $\begin{array}{l}\text { Cumprir 05 200 dias letivos e } 800 \text { horas de trabalho Pedagógico do Ensino } \\
\text { Fundamentale Médio }\end{array}$ & $100 \%$ & $100 \%$ \\
\hline Cumprir 90\% de frequência de professores do Ensino Fundamental e Médio & $90 \%$ & $90 \%$ \\
\hline Cumprir 90\% frequéncia de alunos do Ensino Fundamentale Médio & $90 \%$ & $90 \%$ \\
\hline Cumprir 90\% frequência de jornada de trabalho dos Funcionánios de apoio; & $90 \%$ & $90 \% 2$ anos \\
\hline Aprovar 90\% dos alunos do Ensino Fundamental; & $48,9 \%$ & $90 \%$ \\
\hline Aprovar 90\% dos alunos do Ensino Médio; & $45,3 \%$ & $90 \%$ \\
\hline Aprovar 60\% dos alunos da EJA Médio; & $25 \%$ & $60 \%$ \\
\hline Diminuir o indice de reprovação da escola de 22, 62 para 20\% & $22,62 \%$ & $20 \%$ \\
\hline Manter a evasão abaixo de 10\% dos alunos da EIA Médio & $8,65 \%$ & 8,65 \\
\hline
\end{tabular}

\begin{tabular}{|c|c|c|c|c|c|c|c|c|c|c|c|c|}
\hline \multirow{3}{*}{$\begin{array}{c}\text { Escola } \\
\text { Fres } \\
\text { Ambrosio }\end{array}$} & $\begin{array}{l}\text { TDEE } \\
\text { observado }\end{array}$ & $\begin{array}{c}\text { DDEB } \\
\text { projetado }\end{array}$ & & & & ; & & & & & & \\
\hline & 2005 & 2007 & 2009 & 2011 & 2007 & 2009 & 2011 & 2013 & 2015 & 2017 & 2019 & 2023 \\
\hline & 3.11 & 3.2 & 2.8 & 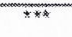 & 3.1 & 3.3 & 3.5 & 3.5 & 3.9 & 4.6 & 4.9 & 5.1 \\
\hline
\end{tabular}


Obs:

*** Sem media na Prova Brasll 2011 devido a creve na Rede Estaduai de Ensino.

\subsection{PERFIL DOS PROFESSORES DA ESCOLA}

"... In profescor sabe gue, se conetruir com amor do vordadc, sua chra com certeza durará para sempre ..."

A açăo escolar precisa ser planejada de forma conjunta com os agentes escolares. Corojeto Pedagógico constitui-se no norteador da escola, por isso, há necessidado de refiletirmos juntos os problemas e os desafios do cotidiano escolar, pois as possíveis respostas só podem expressar a realidade no momento em que a comunidade discute o que realmente deseja.

Considerando todos esses aspectos, os profissionais do ensino da escola, sentem-se desafiados a propor uma nova forma de ensinar, tendo como principio os trabalhos interdisciplinares, buscando superar a fragmentação do conhecimento e formar ûm aluno com uma compreensão mais ampla da realidade, suas propostas sãu:

- Assiduídade

- Pontualidade;

- Dinamismo;

- Comprometimento com o processo ensino-aprendizagem, bem como, participar de todas as atividades desenvolvidas na escola, incluídas no calendário escolar;

- Responsabilidade com a entrega das notas e avaliações;

- Docentes capacitados e comprometidos e conscientes com a educação, uma vez que as ações necessitam ser integradas e compartilhadas, visando o bom andamento da escola;

- Um trabalho interdisciplinar, promovendo assim, mudança na forma de ensinar, pois requer planejamento conjunto.

- Motivados

- Empreendedores e proativos

A escola se propôe a criação de momentos de integração e planejamento por áreas do conhecimento e execução dos projetos previstos no Projeto Político Pedagógico, PROEMI, dentre outros.

\subsection{PERFIL DA EQUIPE GESTORA DA ESCOLA}

O exercicio da democracia se faz através da interação e do diálogo entre pessoas que tem pensamentos distintos e buscam objetivos diferentes. Implica na capacidade de discutir, elaborar, estabelecer metas e regras, aceitando as decisōes tomadas pelo grupo, bem como superar entraves e divergências, por meio do diálogo, a fim de que se construam objetivos comuns. A realidade escolar apresenta-se da mesma forma. Nela encontra-se diversidades e conflitos de interesses.

Gerir uma escola através de ações democráticas e particípativas se faz pelo diálogo e pelas ações dinâmicas da comunidade escolar, estabelecendo metas e diretrizes com base nos principios de gestão participativa.

Trabalhar coletivamente significa envolver açōes e decisōes de toda a comunidade escolar nas atividades desenvolvidas na escola, compartithando responsabilidades, aceitando sugestöes criativas e inovadoras, respeitando 
opiniōes e caminhando junto em busca de um único fim: a educação de qualidade.

A equipe gestora da escola, trabalhará neste sentido, buscando construir e implementar um projeto pedagógico no qual as ações e tomadas de decisōes sejam compartihadas e aprovadas pelo grupo, a fim de difundir a proposta da escola e motivar a participaçäo de toda a comuridade escolar.

De acordo com o seguinte diagrama:

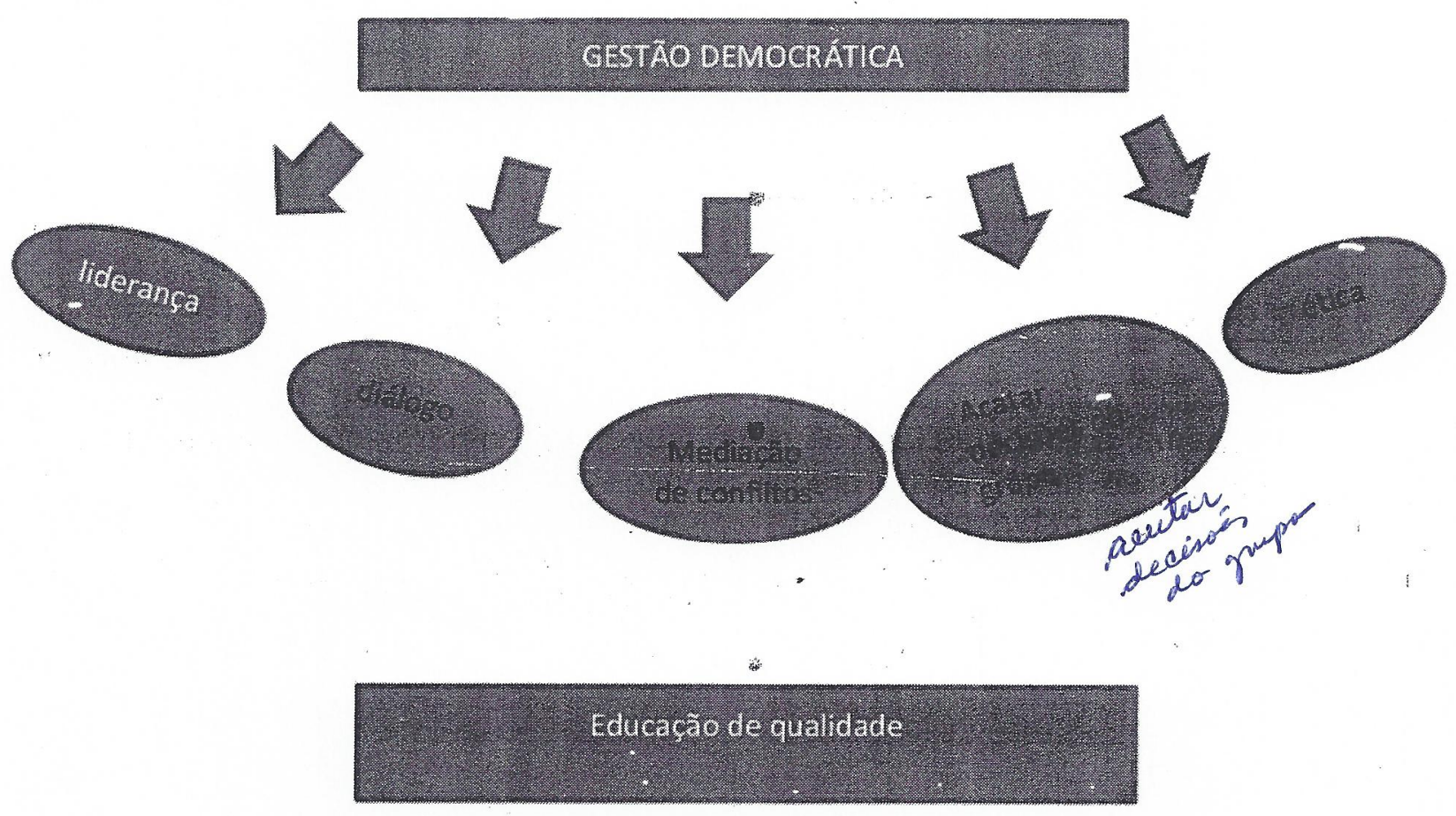

Desta forma a equipe gestora da escola, está assim constituida:

\begin{tabular}{|c|c|c|c|}
\hline NOME & FUNGÁO & FORMACĀOO & TURNO DE ATUACAO \\
\hline Marcos Venicio S. Botelho & Diretor & $\begin{array}{l}\text { Bacharel e Licenciado Pleno em } \\
\text { História } \\
\text { Especialização em Gestăo, } \\
\text { Administração, Supervisão e } \\
\text { Orientação escolar. }\end{array}$ & Manhã,Tarde e Noite \\
\hline Plerlisia Moreira Pereira & $\begin{array}{c}\text { Vice } \\
\text { Diretora }\end{array}$ & $\begin{array}{lcr}\text { Licenciatura } & \text { Plena } & \text { em } \\
\text { Pedagogia. } & \text { Bacharel } & \text { em } \\
\text { Administração. } & & \\
\text { Especialização } & \text { em: - Gestão } \\
\text { Escolar. } & \text { Planejamento } \\
\text { Estratégico. } & \text { Mestranda em } \\
\text { Educação. } & & \end{array}$ & Manhã e Tarde \\
\hline
\end{tabular}

\subsection{PERFIL DA EQUIPE TÉCNICA DA ESCOLA}

A escola tem por finalidade a formação do homem. Nesse sentido é responsável pela garantia das condições necessárias para desenvolver, habilidades, tanto emocional, cultural e intelectual. $E$ com base nesse referencial, que a equipe técnica pedagógica procurará: 
- Participar com a comunidade escolar da construção do projeto politico pedagógico;

- Promover integração da escola, famillia e ccmunidade, envolvendoos nas ações educativas da unidade de ensino;

- Fornecer subsidio ao trabalho docente visando a melhoria do processo ensino aprondizagem;

- Orientar, acompanhar e avaliar o conjunto técnicos

- Informar continuamente aos pais/ responsáveis sobre o desemporho escolar dos filhos

- Interagir interdisciplinarmente com os profissionais da escola

Desta forma estará desenvolvendo um trabalho de acompanhamento dos docentes e discentes, com intuito de dirimir os problemas, dinamizar as açכ̄es a fim de viabilizar objetivos que a escola pretende alcançar dentro de um desenvolvimento competente do processo educacional.

Assim, a equipe se propõe a desenvolver uma ação integrada que atinja não só as reais necessidades dos edúcandos, mas também, toda a comunidade escolar em geral.

Atualmente, a escola conta com o trabalho de 3 técnicos, sendo assim distribuídos:

\begin{tabular}{|c|c|c|c|}
\hline NOME & FUNCAO & FORMACAO & $\begin{array}{l}\text { TURNO } \\
\text { ATUACEAOC }\end{array}$ \\
\hline $\begin{array}{l}\text { Simara Bernardes } \\
\text { Lemos }\end{array}$ & Técnico em Educação & $\begin{array}{l}\text { Licenciatura Plena em } \\
\text { Pedagogia }\end{array}$ & Manhä \\
\hline Adilena Vieira de Araújo & Técnico em Educação & $\begin{array}{l}\text { Licenciatura Plena em } \\
\text { Pedagogia } \\
\text { pós em gestão de } \\
\text { instituicōes de Ensino }\end{array}$ & Tarde \\
\hline $\begin{array}{l}\text { Risete Maria Ferreira de } \\
\text { Sousa }\end{array}$ & Técnico em Educação & $\begin{array}{l}\text { Licenciatura Plena em } \\
\text { Pedagogia }\end{array}$ & Noite \\
\hline
\end{tabular}

\subsection{DESCRIÇÃO DOS ESPAÇOS ESCOLARES}

Ao abordarmos os espaços escolares, relacionamos os diversos segmentos que expressam a realidade educacional, nos aspecios fundamentais quanto à organização do trabalho pedagógico e administrativo, objetivando a qualidade do ensino.

A escola consta assim estruturada:

- 01 secretaria;

- 01 sala dos professores;

- 01 sala de arquivo;

- 01 sala de direção;

- 01 sala do setor pedagógico;

- 02 recreios cobertos;

- 04 depósitos; -

- Oi cozinha

- 02 banheiros para os alunos;

- 01 banheiro na sala dos professores;

- 01 cantina; -

- 12 salas de aulas.

- 01 guarita com banheiro 
- 01 biblioteca

- 01 laboratório de Informática

- 01 laboratório de multidisciplinar

- 01 sala de multimídia -

- 01 sutite multimidia

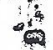

\subsubsection{NECESSIDADES DA ESCOLA}

A educacaano requer mudanças no que tange a forma de ensino, visto que as transiormações ocorridass na sociedade devido às revoluções tecnológicas e a velocidade das informações desafia a escola, pois o conhecimento é reelaborado continuamente. Nesse contexto o ensino precisa primar pela "formação" geral do aluno tendo em vista o desenvolvimento de capacidades de pesquisas, buscar informações analisá-las e selecioná-las; a capacidade de aprender, criar, formular. ao invés do simples exercício de memorização (Parâmetros Curriculares Nacionais/PCN!s).

Na perspectiva dos parâmetros curriculares é evidente a necessiciade da superação das dificuldades da escola. Entre estão:

\begin{tabular}{|c|c|}
\hline $\begin{array}{l}\text { ENSINO FUNDAMENTAL } \\
5^{\mathrm{A} A 8^{\mathrm{S}} \text { SERE }} \\
6^{\circ} \mathrm{AO} 7^{\circ} \mathrm{ANO}\end{array}$ & $\begin{array}{l}\text { - Ausência da familia para acompanhar os trabalhos } \\
\text { escolares; } \\
\text { - Indisciplina por parte dos alunos; } \\
\text { - Falta de metodologias inovadoras; } \\
\text { - Aquisição de mấs recursos didáticos e multimídia; } \\
\text { Redução do número de dependência de estudos, onde eles } \\
\text { não levam a sério; }\end{array}$ \\
\hline $\begin{array}{l}\text { EDUCAGAO DE JOVENS E } \\
\text { ADULTOS }\end{array}$ & $\begin{array}{l}\text { - Os alunos tem deficiência na aprendizagem devido: } \\
\text { - Pouca leitura e a escrita; } \\
\text { - Desinteresse peles estudos; } \\
\text { - Baixa auto-estima } \\
\text { - Cansaco físico e mental }\end{array}$ \\
\hline $\begin{array}{l}\text { ENSINO MEDIO } \\
1^{\circ} \mathrm{A} 3^{\circ} \mathrm{ANO}\end{array}$ & $\begin{array}{l}\text { - Indisciplina } \\
\text { - Desmotivacão } \\
\text { Falta de interesse pelos processos seletivos } \\
\text { - Pouca participacão dos alunos nos eventos da escola }\end{array}$ \\
\hline TODAS AS MODALIDADES & $\begin{array}{l}\text { - Climatizacão das salas de aula; } \\
\text { - Ampliaçáo dos banheiros; } \\
\text { - Falta de material didático } \\
\text { - É preciso melhorar o ensino e a relação do professor com o } \\
\text { aluno. } \\
\text { - Monitorar a assiduidade e a pontualidade de funcionários e } \\
\text { alunos; } \\
\text { - Falta cobertura da quadra esportiva; } \\
\text { - Falta formação continuada para professores- Oficinas; } \\
\text { - Pectece-se ainde que a escela precisa de funcionários de } \\
\text { apoio ao servico administrativo e pedagógico da escola. }\end{array}$ \\
\hline
\end{tabular}

3. MARCO TEÓRICO

3.1. CONCEPÇÃO PEDAGÓGICA

1. 
2. A prática pedagógica será norteada pela linha progressista Crítico Social dos Conteúdos.

A tendência Critico Social dos Conteúdos que propõe uma sintese superadora da pedagogia tradicional e renovada valorizando a açăo pedagógica enquanto inserida na pratica social concreta. Entende-se que a escola coma mediação entre o individual e o social exercendo ai a articulação

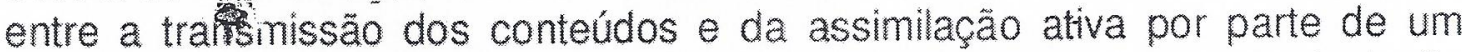
aluno concreto (inserido num contexto de relacōes sociais) dessa articulacão resulta o saber criticamento reelaborado.

Portanto, desses princípios que surgiram à necessidade da Escola Estadual de Ensino Fundamental e Médio Frei Ambrósio demonstrar através de seu projeto pedagógico, a toda comunidade escolar e em geral, a concepção pedagógica que vem desenvolvendo gradativamente: crítico social dos conteúdos. Nossa tarefa através da utilizacão dessa concepção consiste justamente em buscar as expectativas, as contradições, as possibilidades de construção de outra escola, crítica, criativa, capaz de atender aos interesses de todas as classes e não somente daquela que hoje está no poder.

É dentro dessa possibilidade, mesmo que estreita, de transformaçäo que vemos espaço aberto para o educador desempenhar um papel ético politico em defesa da humanização, da formação de pessoas criticas com consciência crítica e reflexiva, capaz de interpretar e intervir em seu meio social, de questionar a legitimação do poder.

Diante das transformações pela qual a sociedade mundial vem passando, a educação hoje desenvolvida em nossa escola visa a formação de um indivíduo com uma educação permanente, bastante empreendedor e adaptado a novas situaçöes (mundo globalizado).

Precisamos transformar nossas salas de aula em local de reflexão, resolução de problemas, onde o conhecimento seja adquirido de maneira interdisciplinar, contextualizado, privilegiando a construção de conceitos. Para tanto, o professor desenvolverá o papel de facilitador da aprendizagem e mediador do conhecimento. Uma vez trabalhadas atividades centradas em projetos integrados, organizadas por área de conhecimento e temas geradores, o aluno se transformará em um participante ativo do processo articulador e assimilador dos conteúdos que resultará em um saber crítico.

Não podemos perder de vista qưte todo trabalho desenvolvido em nossas escolas precisam ser avaliados, como reforço desse processo utilizaremos as palavras de LUCKESI, que apontam um possivel caminho a ser seguido para o alcance de uma prática avaliativa voltada à transformação do educando, negando assim, o ato avaliativo inserido na pedagogia tradicional: " Um educador, que se preocupa com que a sua prática educacional esteja voltada para a transformação, nāo pode agir inconscientemente e irrefletidamente. Cada passo de sua açäo deverá estar marcada por uma decisăo clara e possivelmente está encaminhando os resultados de sua ação" (1997: 46).

\subsection{Fundamentos teóricos}

\subsubsection{Concepção de socledade,}

A sociedade concebida como produto do homem de maneira criadora e transformista; deve ser desmistificada para que promova a conscientização da realidade.

\subsubsection{Concepçäo de homem,}


O homem é um ser inacabado, incluso, em construção. É um ser finito que ntho teima em não se aceitar como tal, buscando, pois, a infinitude. Como inacabado busca completar-se, num processo ao mesmo tempo infinito e impossivel. Por outro lado, o homem, comc dizia Aristóteles, é um ser social. O ser constrój, constrói o mundo material e simbólico, constrói a verdade no encontro cóm o outro. É no rosto do outro, no apelo que este rosto nos faz, na interiorização que este rosto nos leva a fazer que, em resposta, construímos o mundo.

\subsubsection{Concepção de Educação}

Educação como processo pelo qual o homem se constrói, na sua relação com o outro, com o mundo, e com o saber acumulado pela sua espécie, de sua cultura, de sua localidade.

O processo educacional näo é um ato de introjeção, ou seja, de preencher um espaço vazio. Não existe espaço vazio para ser preenchido, mas uma estrada infinita, com infinitos entroncamentos e cruzamentos. O outro, o mundo material, o saber acumulado, o processo educativo, ao contrário de segurar a construção do homem em parâmetros estabelecidos, abre-lhe horizontes á partir do saber acumulado, não lhe dá certezas, a não ser de que ele precisa se construir. Desta forma, o honem não é uma tábua rasa, onde se escreve o que se quer, mas um ponto no infinito, um ponto em expansão. Negar-lhe esta expansão é negar-the o ser.

\subsubsection{Concepção de Escola}

A escola deve apresentar-se como urii instrumento de apropriação do saber e agente transformador da sociedade. O principal papel desempenhado pela escola, neste contexto, é o de preparaŕ os alunos para o mundo em que vivem tornando-os seres críticos conscientes das contradiçōes existentes na sociedade da qual fazem parte.

A escola, como parte integrante da sociedade, deve agir com o intuito de transformação desta mesma sociedade e não como adaptadora do indivíduo à sociedade ou como mera reprodutora da ordem social instituída. A atuação da escola consiste na preparação do aluno para o mundo adulto e suas contradiçōes, fornecendo-the um instrumental, por meio da aquisição de conteúdos e da socialização, para uma participação organizada e ativa na democratização da sociedade. Sendo a escola parte integrante do todo social deve servir aos interesses populares garantindo um bom ensino, preparando o aluno para o mundo, proporcionando-lhe a ăquisição dos conteúdos concretos e significativos, fornecendo-lhe instrumenial para a sua inserção no contexto social de forma organizada e ativa.

\subsubsection{Concepção de conhecimento}

O conhecimento é importante e se torna instrumento de poder. Esse poder val ser atingido na medida em que se conhece e se discute, a partir do meu cotidiano, que é aquilo que está mais próximo da realidade. Quanto mais nós conhecemos o mundo, melhor estaremos preparados para um vínculo de atuação como cidadão. Não se pode exercer de maneira consciente a cidadania se não se tem com clareza o conhecimento dos direitos a nós assegurados.

Por isso, nós precisamos desenvolver o conhecimento (SABER) nos educandos, o mais rápido possível dos instrumentos de produção e de organização da vida social, do acesso aos meios culturais, sociais e políticos que poderão preparar o educando para o exercício da cidadania. 
O professor, com funçöes de ensinar costumes ou conhecimentos especificos; tem uma longa prática na história da humanidarle. Isto é típico da sociedade que separa vida da escola, levando à divisão social do saber que é regulado a partir do poder.

A separação e o controle do saber e o começo de sua institucionalizaça pelo Estado fornece um controle político do saber e de seus mecanismos de distribuição, o que contribui para que uma desigualdade social comece a ser vista como uma desigualdade natural, com conscquencias sobre o desenvolvimento da cultura.

Para entender a questão do conhecimento é preciso que exista uma unidade entre o objetivo e o subjetivo no ato de conhecer. A educação deve oportunizar a captação crítica dos dados $e$ das relações causais $e$ circunstanciais da realidade, o que define um posicionamento a respeito da validade e dos critérios de seleção dos conteúdos a serem abordados e discutidos.

Entende-se aqui por conteúdos válidos aqueles que ajudam as pessoas a compreenderem a realidade buscando sua transformaçáo, utilizando-os como instrumento para essa transformação.

A construção do conhecimento considera o esforço próprio do aluno que se reconhece nos conteúdos e modelos sociais apresentados pelo professor; assim, pode ampliar sua própria experiência. $O$ conhecimento novo se apóia nuria estrutura cognitiva já existente, ou o professor provê a estrutura de que o aluno ainda não dispõe. O grau de envolvimento na aprendizagem depende tanito da prontidão e disposição do aluno quanto do professor e do contexto da sala de aula.

\subsubsection{Concepção de ensino-aprendizagem,}

No processo ensino-aprendizagem não basta ter como conteúdo escolar as questões sociais atuais, mas é necessário que o aluno possa se reconhecer nos conteúdos e modelos sociais apresentados para desenvolver a capacidade de processar informaçöes e lidar com os estímulos do ambiente buscando ampliar as experiências e adquirir o aprendizado.

Os métodos devem buscar favorecer a coerência entre a teoria e a prática, ou seja, a correspondência dos conteúdos com os interesses dos alunos. A aprendizagem se dá quando o aluno ultrapassa sua visão parcial e confusa e adquire uma visão mais clara e unificadora.

\subsubsection{Concepção de cidadania e cidadão}

Ser cidadão é ser sujeito do procęsso histórico, em contraposição ao ser objeto, sobre o qual incide a ação do sujeito: ser agente construtor do espaço cultural em deverá viver.

Constituir-se como cidadão é assumir-se protagonista do processo histórico. Assim, o cidadäo não delega responsabilidades, não deixa parte de si para outros. Ele luta pelo bairro onde está, luta politicamente, não aceita perder conquistas já alcançadas, exige salário digne para aquilo que faz, exige justiça para si e para o os outros. No processo político, o cidadão busca construir a cidadania participativa, pois sabe que a democracia representativa é alienante. É redutora de seu ser.

\subsubsection{Concepção de Cultura}

A cultura deve ser compreendida, como parte da prática e do poder. É uma esfera de luta continuada de pessoas para afirmar suas histórias e 
espaços de vida. A dominação pela cultura vai se dar quando silenciam ativamente as culturas subordinadas.

A cultura para ser emancipatória precisa ser uma expressão concreta da afirmacáo. da resistência e da luta do povo para ter lugar no mundo.

As classes populares devem apropriar-se democraticamente da cultura erudita e do conhecimento sistematizado, a partir destes, tornarem-se sulgitos de sua ptoptia histón e encontrarem caminhos para a transfomaçâ da realidade.

\subsubsection{Concepção de Avaliação:}

Q processo avaliativo da Escola Frei Ambrósio ocorre nos termos da Lel de Diretrizes e Bases da Educação Nacional prevalecendo sempre os aspectos qualitativos sobre os aspectos quantitativos.

$\therefore$ Escola tem como princípio a ideia de que a Avaliação é parte do processo de aprendizagein, portanto, deverá estar voltada para tal. Todo trabalhn realizado pelo aluno é em potencial um instrumento avaliativo. Provas, trabalhos de pesquisa, listas de exercícios (individuais ou em grupo), entre outros, devem avaliar os conteúdos e habilidades de forma clara e inteligivel visando sempre a excelência educacional. Os instrumentos devem avaliar o aluno passo a passo, de forma contínuada.

Diante disso, A Escola Frei Ambrósio trará para a sala de aula um novo sentido para a aprendizagem e avaliaço. Isto sera possivel numa escola que leve em consideração $0^{\circ}$ acesso aos bens culturais, ao conhecimento produzido historicamente, e possa adquirir habilidades para transformar esses conteúdos no contexto social. Assim, a prática pedagógica e a prática de avaliação deverão superar o autoritarismo, 0 conteudismo, a punição, estabelecendo uma nova perspectiva para o processo de aprendizagem e de avaliaçäo educacional, marcado pela autonomia do educando e pela participação, do aluno na sociedade de forma democrática.

\subsubsection{Concepção de Gestão democrática}

As mudanças vividas na atualidade (décadas de 80 e 90 ) em nivel mundial, em termos econômicos, sociais e culturais, com a transnacionalização da economia e o intercâmbio quase imediato de conhecimentos e padröes sociais e culturais, através das novas tecnologias da comunicação, entre outros fatores, têm provocado uma nova atuação dos Estados nacionais na organização das politicas públicas, por melo de um movimento de repasse de poderes e responsabilidades dos govemos centrais para as comunidades locais. Na educação, um efeito deste movimento são os processos de descentralização da gestão escolar, hoje percebidos como uma das mais importantes tendências das reformas educacionais em nivel mundial (AbiDuhou, 2002) e um tema importante na formação continuada dos docentes e nos debates educacionais com toda a sociedade.

A gestão democrática da educação formal está associada ao estabelecimento de mecanismns legais e institucionais e à organização de açōes que desencadeiem a participação social: na formulação de políticas educacionais; no planejamento; na tomada de decisōes; na definição do uso de recursos e necessidades de investimento; na execução das deliberaçōes coletivas; nos momentos de avaliação da escola e da política educacional. Também a democratização do acesso e estratégias que garantam a permanência na escola, tendo como horizonte a universalizaçăo do ensino para 
toda a população, bem como o debate sobre a qualidade social dessa educação universalizada, são questões que estão relacionadas a esse debate. Esses processos devem garantir e mobilizar a presença dos diferentes atores envolvidos, que participam no nível dos sistemas de ensino e no nivel da escola (Medeiros, 2003).

Esta proposta está presente hoje em praticamente todos os discursos da reforma educacional no que se refere à gestão, constituindo um "novo senso comum", soia pelo reconhecimonto da importancia da educação na democratizaçăo, regulação e "progresso" da sociedade, seja pela necessidade de valorizar e considerar a diversidade do cenário social, ou ainda a necessidade de o Estado sobrecarregado (Barroso, 2000) "aliviar-se" de suas responsabilidades, transferindo poderes e funçōes para o nivel local.

'Em nivel prático, encontramos diferentes vivências dessa proposta, como a introdução de modelos de administração empresariais, ou processos que respeitam a especificidade da educação enquanto nolitica social buscando a transformação da sociedade e da escola, através da participação e construção da autonomia e da cidadania. Falar em gestão democrática nos remete, portanto, quase que imediatamente a pensar em autonomia e participaçăo.

Pensar a autonomia é uma tarefa que se apresenta de forma complexa, pois se pode crer na idela de liberdade total ou independência, quando temos de considerar os diferentes agentes sociais e as muitas interfaces e interdepenuências que fazem parte da organização educacional. Por isso, deve ser muito bem trabalhada, a fim de equacionar a possibilidade de direcionamento camuflado das decisões, ou a desarticulação total entre as diferentes esferas, ou o dominio de um determinado grupo, ou, ainda, a desconsideração das questóes mais amplas que envolvem a escola.

Outro conceito importante é o da participação, pois também pode ter muitos significados, além de poder ser exeroida em diferentes niveis. Podemos pensar a participaçáo em todos os momentos do planejamento da escola, de execução e de avaliação, ou pensar que participação pudesse ser apenas convidar a comunidade para eventos ou para contribuir na manutenção e conservação do espaço físico. Portanto, as conhecidas perguntas sobre "quem participa?" "como participa?" "no que participa?", "qual a importância das decisōes tomadas?" devem estar presentes nas agendas de discussão da gestão na escola e nos espaços de definição da política educacional de um município, do estado ou do país.

A Escola Frel Ambrósio numa perspectiva democrática pretende fortalecer os instrumentos e práticas que organizam a vivência da gestão escolar. Em geral, esses processos meselam democracia representativa instrumentos e instâncias formais que pressupōem a eleição de representantes, com democracia participativa - estabelecimento de estratégias $e$ fóruns de participaçăo direta, articulados e dando fundamento a essas representaçōes.

Defendemos a eleição de diretores de escola e a constituição de conselhos escolares como formas mais democráticas de gestão. Outro elemento indispensável é a descentralização financeira, na qual o governo, nas suas diferentes esferas, repassa para as unidades de ensino recursos públicos a serem gerenciados conforme as deliberações do conselho escolar. Estes aspectos utilizados na escola estarão conformados na legislação local, nos 
regimentos escolares e regimentos internos dos órgãos da própria escola, como o Conselho Escolar e a ampla Assembleia da Comunidade Escolar.

Funcionando em uma perspectiva democrática a Escola Fre: Ambrósio dará condições para que o Conselho Escolar atue de forma paricipativa com todos os segmentos escolares (pais, professores, alunos, funcionários) garantindo acesso às informaçōes relevontes para a tomada de decisōes pfra que haja transparência nas negociações entre os representantes dos interes. muitas vezes legitimamente contitantes, dos diferentes segmentos. Wa comunidade escolar. Os conselhos e assembleias escolares cerão funçōes deliberativas, consultivas e fiscalizadoras, de modo que possam dirigir e avaliar todo o processo de gestäo escolar, e não apenas funcionar como instância de consulta.

A elaboração do projeto político pedagógico, será construido através do planejamento participativo, desde os momentos de diagnóstico, passando pelo estabelecimento de diretrizes, objetivos e metas, execução e avaliação, a escola pode desenvolver projetos específicos de interesse da comunidade escolar, que devem ser sistematicamente avaliados e revitalizados. A gestão democrática da escola significa, portanto, a conjunção entre instrumentos formais - eleição de direção, conselho escolar, descentralização financeira - e práticas efetivas de participação, que conferem a cada escola sua singularidade, articuladas em um sistema de ensino que igualmente promova a participação nas politicas educacionais mais amplas.

\subsubsection{Cońcepção de currículo}

O. currículo, enquanto instrumentação da cidadania democrática, deve contemplar conteúdos e estratégias de aprendizagem que capacitem 0 ser humano para a realização de atividades nos três domínios da ação humana: a vida em sociedade, a atividade produtiva e a experiência subjetiva, visando à integração de homens e mulheres no tríplice universo das relações políticas, do trabalho e da simbolização subjetiva.

Nessa perspectiva, incorporam-se como diretrizes gerais e orientadoras da proposta curricular as quatro premissas apontadas pela UNESCO como eixos estruturais da educação na socledade contemporânea:

* Aprender a conhecer

Considera-se a importância de uma educação geral, suficientemente ampla, com possibilidade de aprofundamento em determinada área de conhecimento. Prioriza-se o domínio tos próprios instrumentos do conhecimento, considerado como meio e como fim. Meio, enquanto forma de compreender a complexidade do mundo, condiçäo necessária para viver dignamente, para desenvolver possibilidades pessoais e profissionais, para se comunicar. Fim, porque seu fundamento é o prazer de compreender, de conhecer, de descobrir.

O aumento dos saberes que permitem compreender o mundo favorece o desenvolvimento da curiosidade intelectual, estimula o senso critico e permite compreender o real, mediante a aquisiçäo da autonomia na capacidade de discernir.

Aprender a conhecer garante o aprender a aprender e constitui o passaporte para a educação permanente, na medida em que fornece as bases para continuar aprendendo ao longo da vida.

* Aprender a fazer 
O desenvolvimento de habilidades e o estímulo ao surgimento de novas aptidóes tornam-se processos essenciais, na medida em que criam as condiçōes necessárias para o enfrentamento das novas situações que se colocam. Privilegiar a aplicação da teoria na prática e enriquecer a vivência da clència na tecnologia e destas no social passa a ter uma significação especial no desenvolvimento da sociedade contemporânea.

Aprender a viver

Tratä-se de aprender a viver juntos, desenvoivendo o conhecimento do outro e a percepção das interdependências, de modo a permitir a realização de projetos comuns ou a gestão inteligente dos conflitos inevitáveis.

\section{* Aprender a ser}

A educação deve estair comprometida com o desenvolvimento total da pessoa. Aprender a ser supõe a preparaçao do indivíduo para elaborar pensamentos autônomos e críticos e para formular os seus próprios juizos de valor, de modo a poder decidir por si mesmo, frente às diferentes circunstâncias da vida. Supõe ainda exercitar a liberdade de pensamento, discernimento, sentimento e imaginação, para desenvolver os seus talentos e permanecer, tanto quanto possível, dono do seu próprio destino.

Aprender a viver e aprender a sêt decorrem, assim, das duas aprendizagens anteriores - aprender a conhecer e aprender a fazer - e devem constituir ações permanentes que visem à formação do educando como pessoa e. como cidadão.

A partir desses princípios gerais, o currículo deve ser articulado em torno de eixos básicos orientadores da seleção de conteúdos significativos, tendo em vista as competências e habilidades que se pretende desenvolver no Ensino

Médio.

Um eixo histórico-cultural dimensiona o valor histórico e social dos conhecimentos, tendo em vista o contexto da sociedade em constante mudança e submetendo o currículo a uma verdadeira prova de validade e de relevância social. Um eixo epistemológiéco reconstrói os procedimentos envolvidos nos processos de conhecimento, assegurando a eficácia desses piocessos e a abertura para novos conhecimentos.

A Base Nacional Comum

É no contexto da Educação Básica que a Lei $n^{2}$ 9.394/96 determina a construção dos currículos, no Ensino Fundamental e Médio, "com uma Base Nacional Comum, a ser complementada, em cada sistema de ensino e estabelecihinento escolar, por uma parte diversificada, exigida pelas caracterishcas regionais e locais da sociedade, da cultura, da economia e da clientela": (Art.,

26).

A Base Nacional Comum contém em si a dimensão de preparação para o prosseguimento de estudos e, como tal, deve caminhar no sentido de que a construção de competências e habilidades básicas, e não o acúmulo de esquemas resolutivos pré-estabelecidos, seja o objetivo do processo de aprendizagem. É importante, por exemplo, operar com algoritmos na Matemática ou na Física, mas o estudante precisa entender que, frente àquele algoritmo, está de posse de uma sentença da linguagem matemática, com 
seleção de léxico e com regras de articulação que geram uma significação e que, portanto, é a leitura e escrita da realidade ou de uma situação desta. Para tanto, deve-se entender que a linguagem verbal se presta à compreensão ou expressão de um comando ou instrução clara, precisa, objetiva.

A Base Nacional Comum também traz em si a dimensão de preparação para o trabalho. Esta dimensão tem que apontar para que aquele mesmo algoritmo seja um instrumento para a solução de um problema concreto, que pode dar conta da etana de planejamento, gestão ou produção de um bem. E, indicando e relacionando os diversos contextos e práticas sociais, além do trabalho, requer, por exemplo, que a Biologia dê os fundamentos para a análise do impacto ambiental, de uma solucão tecnológica ou para a prevenção de uma aoença profissional. Enfim, aponta que não há solução tecnológica sem uma base científica e que, por outro lado, soluções tecnológicas podem propiciar a produção de um novo conhecimento científico.

Essa educação geral, que permite buscar informação, gerar informação, usá-la para solucionar problemas concretos pa produção de bens ou na gestäo e prestação de serviços, é preparação básica para o trabalho. Na verdade, qualquer competência requerida no exercício profissional, seja ela psicomotora, socio-afetiva ou cognitiva, é um afinamento das competências básicas. Essa educação geral permite a construção de competências que se manifestar-se-ão em habilidades básicas, técnicas ou de gestão.

A Base Nacional Comum destina-se à to assegurar que as finalidades propostas em lei, bem como o perfil de saída do educando sejam alcançadas de forma a caracterizar que a Educação Básica seja uma efetiva conquista de cada brasileiro.

O desenvolvimento de competências e habilidades básicas comuns a todos os brasileiros é uma garantia de democratização. A definição destas competências e habilidades servirá de parâmetro para a avaliação da Educação Básica em nivel nacional.

O Art. 26 da LDB determina a obrigatoriedade, nessa Base Nacional Comum, de "estudos da Língua Portuguesa e da Matemática, o conhecimento do mundo físico e natural e da realidade social e politica, especialmente do Brasil, o ensino da arte [...] de forma a promover o desenvolvimento cultural dos alunos, e a Educaçăo Fisica, integrada à proposta pedagógica da escola".

Quando a LDB destaca as diretrizes curriculares específicas do Ensino Fundamental $e$ Médio, ela se preocupa em apontar para um planejamento e desenvolvimento do currículo de forma orgânica, superando a organização por

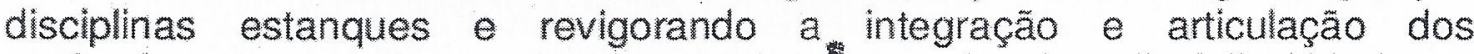
conhecimentos, num processo permanênte de interdisciplinaridade e transdiciplinaridade.

É importante compreender que a Base Nacional Comum não pode constituir uma camisa-de-força que tolha a capacidade dos sistemas, dos estabelecimentos de ensino e do educando de usufruírem da flexibilidade que a lei não só permite, como estimula. Essa flexibilidade deve ser assegurada, tanto na organização dos conteúdos mencionados em lei, quanto na metodologia a ser desenvolvida no processo de ensino-aprendizagem e na avaliação.

As considerações gerais sobre a Lei indicam a necessidade de construir novas alternativas de organização curricular comprometidas, de um lado, com o novo significado do trabalho no contexto da globalização econômica e, de 
outro, com o sujeito ativo que se apropriar-se-á desses conhecimentos, aprimorando-se, como tal, no mundo do trabaho e na prática social.

Ressalve-se que uma base curricular nacicnal organizada por áreas de conhecimento não implica a desconsideração ou o esvaziamento dos conteudos, mas a seleção e integraçäo dos que são válidos para o desenvolvimento pessoal e para o incremento da participação social. Essa concepção curricular não elimina o ensino de conteúdos específicos, - mas considera que os mesmos devem fazer parte de um processo global com várias dimensões articuladas.

O fato de estes Parâmetros Curriculares terem sido organizados em cada uma das áreas por disciplinas potenciais não significa que estas são obrigatórias ou mesmo recomendadas. O que é obrigatório pela LDB ou pela Resolução nº 03/98 são os conhecimentos que estas disciplinas recortam e as competências e habilidades a eles reteridos e mencionadns nos citados documentos.

- A parte diversificada do curriculo

A parte diversificada do curriculo destina-se a atender às características regionais e locais da sociedade, da cultura, da economia e da clientela (Art. 26 da LDB). Complementa a Base Nacional Comum e será definida em cada sistema de ensino e estabelecimento escolar.

Do ponto de vista dos sistemas de ensino, está representada pela formulação de uma matriz curricular básica, que desenvolva a Base Nacional Comum, considerando as demandas regionais do ponto de vista sociocultural, econômico e político. Deve refletir uma concepção curricular que oriente o Ensino Médio no seu sistema, resignificando-o, sem impedir, entretanto, a flexibilidade da manifestação dos projetos curriculares das escolas.

A parte diversificada do curriculo deve expressar, ademais das incorporações dos sistemas de ensino, as prioridades estabelecidas no projeto da unidade escolar e a inserção do educando na construção do seu currículo. Considerará as possibilidades de preparação básica para o trabalho e o aprofundamento em uma dísciplina ou uma área, sob forma de disciplinas, projetos ou módulos em consonância com os interesses dos alunos e da comunidade a que pertencem.

O desenvolvimento da parte diversificada pode ocorrer no próprio estabelecimento de ensino ou em outro estabelecimento conveniado. E importante esclarecer que o desenvolvimento da parte diversificada não implica profissionalização, mas diversificação de experiências escolares com o objetivo de enriquecimento curricular, ou mesmo aprofundamento de estudos, quando o contexto assim exigit. O seu objetivo principal é desenvolver e consolidar conhecimentos das áreas, de forma contextualizada, referindo-os a atividades das práticas sociais e produtivas.

\section{PROGRAMA EM ATIVIDADE NA ESCOLA}

1. Mais Educação

2. PROEMI (Esporte na Escola, Rádio Escolar)

3. PNLD

4. PNAE 

5. PDE
6. PDDE

\section{PROJETOS EM ATIVIDADE NA ESCOLA}

1. Enem Solidário

2. Sol Cidadão Legal - Educação Fiscal, Prefeitura Mirim

3. Fanfarra (alunos e ex-alunos)

4. Feira do Conhecimento

5. Africanidade (nossas raízes) - anual

6. Resgate da história da escola (Eurenice)

AÇÕES DESENVOLVIDAS NA ESCOLA (ver calendário em anexo)

1. PROABI (Processo Avaliativo Bimestral)

2. Aniversário da escola - mês de maio

3. Festa Junina - mês de junho

4. Jogos Internos - mês de dezembro

5. SESG - ORIENTAÇÃO SOBRE DST

6. Conselho de classe

7. Reunião de pais

8.

9.

\section{Regimento escolar ()}

Plano de cursos

Grade curricular

Calendário 2014

\section{ATO OPERACIONAL}

Ato operacional: delineia a luta esperançosa - as mudanças significativas a serem alcançadas

- Define as grandes linhas de ação e a reorganização do trabalho pedagógico escolar na perspectiva administrativa, pedagógica, financeira e político-educacional

- Apresenta as grandes linhas de ações em termos de: redimensionamento da gestão democrática: conselho escolar, conselho de classe, grêmio estudantil, eleiçäo de aluno representante de turma, APMF e outros.

- Definição das açōes relativas à formação continuada: professores, funcionários, alunos representantes de turma, conselheiros e pais, em termos de atendimentos às especificidade dos niveis e modalidades de ensino

- Dualificação dos equipamentos pedagógicos: salas, biblioteca, laboratórios, pátios, etc.

- Especificação das ações que envolvem outras instituições e/ou especificidade curriculares.

- Delimitação clara das açōes relativas à recuperação de estudo dos alunos.

- Proposição de diretrizes para avaliação geral de desempenho dos docentes, dos pedagogos e dos funcionários. 
- Organizar o trabalho pedagógico e a prática docente, a partir do curr鼠lo enquanto núcleo do Projeto político-pedagógico.

REFERÊNCIAS

GANDIN, Danilo, GANDIN, Luiz Armando. Temas para um projeto político pedagógico. $4^{0}$ Ed. São Paulo: Vozes 2003.

VEIGA, IIma P. A. (org.). Projeto político-pedagógico da escola. uma construça possivel. Campinas. Papirus, 1996.

Lei de Diretrizes e Bases da Educação. Curitiba: Ed. América, 1938. Diretrizes Nacionais Para Organização Curricular do Ensino Médio. Brasília: MEC, 1998.

Libaneo, José Carlos. Democratização da escola pública: a pedagogia crítico-social dos conteúdos. São Paulo, Ed. Loyola, 1986.

LUCKESI, Cipriano C. A avaliação da aprendizagem escolar. São Paulo, Cortez, 1995.

Luckesi, Cipriano C. Para além do autoritarismo. Revista Educando, Número 171, Ano: 18 , maio/1985.

MEC. A área de Ensino Sociedade e Cultura no Currículo do Ensino Médio. Penteado, H. D. 1997

Saviani Dermeval. Escola e democracia. São Paulo, Cortez Editora, 1986. 